\section{v. 2}

\section{UC-NRLF \\ m \\ 1.m. \\ C 2 819 644}

U. S. DEPARTMENT OF AGRICULTURE

FOREST SERVICE

WILLIAM B. GREELEY. FORESTER

TIMBER DEPLETION, LUMBER PRICES, LUMBER

EXPORTS, AND CONCENTRATION OF

TIMBER OWNERSHIP

REPORT UN SENATE RESOLUTION 311

By

The Forest SERVICE

U S. DEPARTMENT OF AGRICULTURE

JUNE 1,1920 


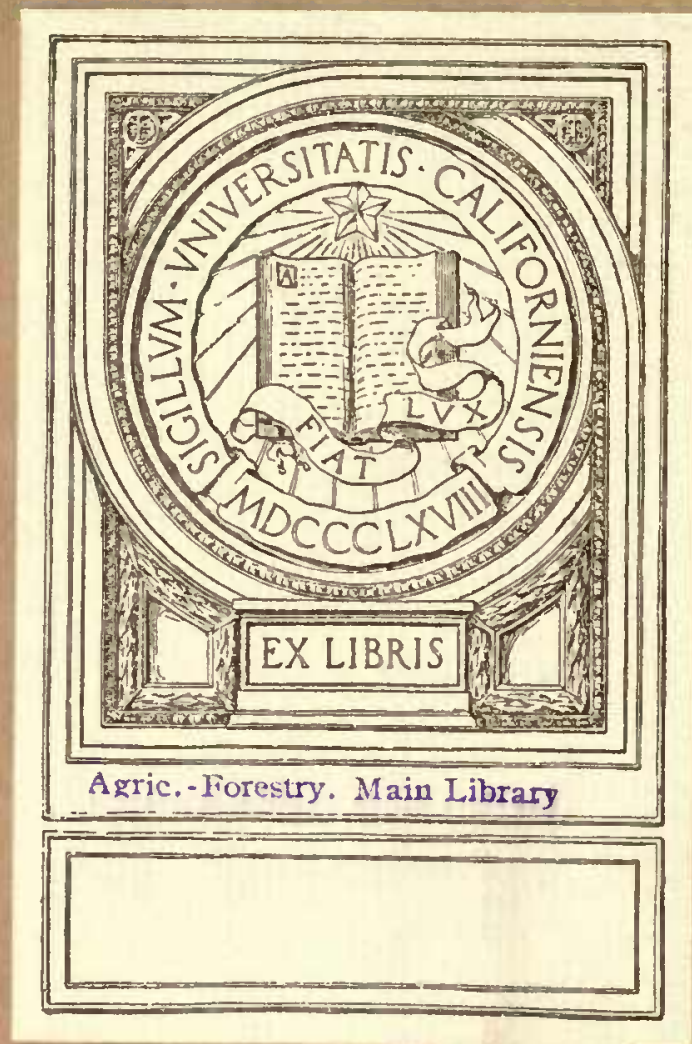





\section{U. S. DEPARTMENT OF AGRICULTURE}

FOREST SERVICE

WILLIAM B. GREELEY, FORESTER

\section{TIMBER DEPLETION, LUMBER PRICES, LUMBER EXPORTS, AND CONCENTRATION OF TIMBER OWNERSHIP}

REPORT ON SENATE RESOLUTION 311

By

The Forest Service

U S. Department of Agriculture

JUNE 1,1920

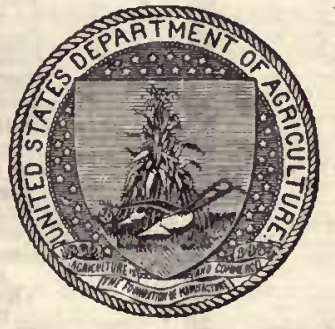




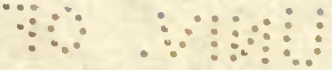

TABLE OF CONTENTS.

Letters of transmittal

liffects of scarcity and high prices of forest products upon rep-

General bulding and construction.

The railroads

The furnitire industry

The vencer industry

The handle industry

The vebicle and agricultural implement hdustries.......-

The newspapers

The sltuation summarized
Ahnormal conditions in relation to present scarcity ail high

prices
steady progress of forest depletion
lorest depletion and migration of the lumber industry

basis for data.

The gruwth and decline of the lumber industry

Ortginal and remaining forests

$$
\text { Area }
$$

The annual drain upon the forest

The annual growth-

The life of the industry

Iresent and future consumption of lumber in New New York

Yorklan

l'he Lake States

Growth and decline of the lumber industry White pine

The northern hardwoods

Original and remaining stand and rate of cut Lcwer Peninsula of Míchigan-Wisconsin and Upper Peninsula of MLichigan..... Minnesota - the remaining suppites

The annual drain upon the forest Lumber cut compared with total cut_.....

The avrual growth

Growth compared with cut

Present and future consumption of lumber in the Lake

States -

The southern yeliow-pine region--

The growth and decline of the yellow-pine industry--

The original and the present pine forests of the south

Annual drain upon the forests

The annual growth

Cut and growth contrasted

Change to inferior spe-

The lesson of the South Atlantic States

The lesson of the South Atlantic states_._-

Reduction of the output.

Present and future consumption of lumber in the south. Cypress reglons

Development of the lumber industry

Original and present stand

The annul drain upon the fl

Annual growth - - compared with growth

The future of the lumber industry

Pacific coast

Growth of the lumber industry

Original and remalning

life of the industry

The Southern Appalachlan hardwoods

Growth and decline of lumbering

The original forest--

Lumber cut and total cut

Deterioration of the forest

The duration of the forest----------- -

The duration of the cut of old growth The annual growth

Growth compared with cut

Importance of the Southern Appalachians in the future mortance of the Southern Apr

Ilardwoods of the lower Mississippi valley Area and stand

Development of the lumber industry

Growth and depletion
Page. 12
Steady progress of forest depletion-Continued.

The facts as to depletion.

Alaskan supplies of pulp wood

The movement of prices

Naval stores supplies
Development of the industry

Development of the industry

Remaining supplles.-.Methods of exploitation..... Depletion and prices

Original and present forests of the United States...... Original forest area

Present forest area

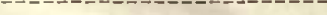

Total stand

Location of requirements with reference to productiou and

supplies.

Huture trends in requirements

Present depletion and growth-

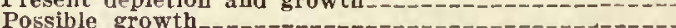

Forest depletion and lumber prices

Prlce changes and regional depletion Vastern softwood market

Middle western markets--

Eastern hardwood markcts-Prices in depleted or nonforested versus forested jegions

Prices and costs of production and distribution

Mill prices and production costs Paclicic coastSouthern pine States

Tholegale pine states

Retall prices and costs The upward mopement of prtces The upward movement of prices Distribution of price increase

Lumber prices unjustified by production and aistribution costs

Price control Summary of principal price conclusions. Lumber exports and timber depletion.

Lumber exports before and during the war. Probable developments in lumber exports

Effects of exports upon domestic timber supplies imports of forest products

Export trade policy

Concentration in timber ownership, manufacture, and marketiug Concentration of timber ownership in 1910

Timber oxpershin in the Northeast Ownership of softwood timber in the Southern States Ownership of hardwood timber.

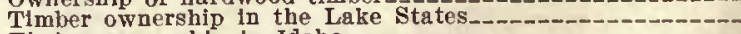
Timber ownershtp in Idaho Timber ownership in Washington and Oregon Timber ownershlp in Callfornta A summary of the present situation as to timber ownership -

keting creation of large operating groups of affilated

Greater financial strength of the lumber industry..Concentration of lumber marketing

Development of trade associations.

mffects of timber depletion upon concentration.-

Forest depletion the fundamental problem

Cumulative effects of timber depletion Timber depletion and lumber prices

Timber depletion and lumber prices....................... A national forestry pollcy

A national forestry policy Cooperation with States in fire protection and forest The extension and consolidation of Federal forest holdThe exten

ings A study of forest taxation and insurance The survey and classification of forest resources......

The State legislation needed.

Fire prevention and reforestation of private lands.-State and municipal forests

Taxation of forest lands
Page. 


\section{LETTERS OF TRANSMITTAL.}

JUNE $1,1920$.

The Preginent of the Uniten States Senate.

Sir: I have the honor to submit herewith a report on forest depletion in the United States, prepared by the Forest Service in this department pursuant to Senate resolution 311.

This resolution requests information on:

1. The depletion of timber in the United States.

2. The effects of timber depletion upon the high cost of materials.

3. The effects of lumber exports upon domestic industries.

4. The effects of depletion upon the concentration of timber ownership and manufacture and the relation of such concentration to the public welfare.

The outstanding facts reported by the Forest Service are:

(1) That three-fifths of the original timber of the United States is gone and that we are using timber four times as fast as we are growing it. The forests remaining are so localized as greatly to reduce their national utility. The bulk of the population and manufacturing industries of the United States are dependent upon distant supplies of timber as the result of the depletion of the principal forest areas east of the Great Plains.

(2) That the depletion of timber is not the sole cause of the recent high prices of forest products, but is an important contributing cause whose effects will increase steadily as depletion continues.

(3) That the fundamental problem is to increase the production of timber by stopping forest devastation.

The virgin forests of the United States covered 822 million acres. They are now shrunk to one-sixth of that area. All classes of forest land, including culled, burned, and cut-over areas, now aggregate 463 million acres, or a little more than one-half of our original forests. Of the forest land remaining and not utilized for farming or any other purpose, approximately 81 million acres have been so severely cut and burned as to become an unproductive waste. This area is equivalent to the combined forests of Germany, Denmark, Holland, Belgium, France, Switzerland, Spain, and Pòrtugal. Upon an enormous additional area the growth of timber is so small in amount or of such inferior character that its economic value is negligible.

The merchantable new timber remaining in the United States is estimated roughly at 2,215 billion board feet, something less than three-fourths of which is virgin stumpage. The rest is second growth of relatively inferior quality. About one-half of the timber left is in the three Pacific Coast States, and over 61 per cent is west of the Great Plains. A little over one-fifth of the timber left in the country, or 460 billion board feet, is hardwoods.

There is now consumed or destroyed annually in the United States 56 billion board feet of material of saw timber size. The total yearly consumption of all classes of timber is about 26 billion cubic feet. Our depleted forests are growing less than one-fourth of this amount. The United States is not only cutting heavily into its remaining virgin forests every year, but is also using up the smaller material upon which our future supply of saw timber depends much more rapidly than it is being replaced.

The two striking effects of timber depletion already apparent are:

(1) The injury to large groups of wood users and to many communities resulting from the exhaustion of the nearby forest regions from which they were formerly supplied; and

(2) The shortage of timber products of high quality.

Less than 5 per cent of the virgin forests of New England remain, and the total stand of saw timber in these States is not more than one-eighth of the original stand. New York, once the leading State in lumber production, now manufactures only 30 board feet per capita yearly, although the requirements of its own population are close to 300 board feet per capita. The present cut of lumber in Pennsylvania is less than the amount consumed in the Pittsburgh district alone. The original pine forests of the Lake States, estimated at 350 billion feet, are now reduced to less than 8 billion feet, and their yearly cut of timber is less than one-eighth of what it used to be. These four densely populated regions, containing themselves very large areas of forest land, are now largely dependent upon timber grown and manufactured elsewhere and are becoming increasingly dependent upon timber which must be shipped the width of the continent.

The bulk of the building lumber and structural timbers used in the Eastern and Central States during the last 15 years was grown in the pine forests of the South. The virgin pine forests of the South Atlantic and Gulf States have been reduced from about 650 billion board feet to about 139 billion feet. The production of yellow-pine lumber is now falling off and within ten years will probably not exceed the requirements of the Southern States themselves.

The United States at one time contained the most extensive temperate zone hardwood forests in the world. One region after another has been cut out. The production of hardwood products on the past scale can not be long continued. The scarcity of high-grade oak, poplar, ash, hickory, walnut, and other standard woods is now placing many American industries in a critical condition.

The depletion of forest resources is not confined to saw timber. Since 1909, the country has ceased being self-supporting in newsprint paper and now imports two-thirds of the pulp, pulp wood, or newsprint which we require. This condition is due in part to timber depletion, in part to failure of the paper industry to expand in our western forest regions as the lumber industry has expanded. In 1919 the production of turpentine and rosin had fallen off 50 per cent. Within ten years the United States will lose its commanding position in the world's market for these products and may in time be unable to supply its domestic requirements.

The termination of the war found the lumber industry with depleted stocks. Production during the war had been much less than normal on account of shortages of labor and equipment and embargoes on transportation. A large part of the lumber produced had been taken by the Government for war purposes: During the same time, the normal construction of dwellingsand industrialstructuresand the use of lumber in many manufacturing industries had been greatly curtailed. Following the war, these pent-up demands were released. They caught the lumber industry not only with its stocks short and broken from war conditions but unable, on account of labor difficulties, 
lack of freight cars, and bad weather in important producing regions, to respond rapidly with increased production. Aside from the general causes affecting prices of most commodities, the expansion of credit accompanied by currency inflation and the wave of speculation and extravagance, an "auction" lumber market would no doubt have resulted from the frenzied competition of buyers to obtain the limited stocks available, wholly inadequate to satisfy current demands.

Under the combined influence of the general conditions making for high prices and this situation in the lumber industry itself, prices rose to unprecedented limits. In March, 1920, average mill prices in the South and West had increased 300 per cent and more over the prices reccived in 19 [4, and average retail prices in the Middle West showed increases ranging from 150 to 200 per cent. In the case of high quality hardwoods and other specialized products, the average advance in eastern wholesale markets was from 200 to 250 per cent, and the demand at this advance was still unsatisfied.

The timber market has been more unstable than ever before in our history. Many industries have been unable to secure their supplies of timber at any price. The output of certain entire industries has been reduced as much as 50 per cent. Nliddlemen and manufacturers of wooden commodities have been able to pass on to the consumer and even augment any price they might pay. Necessities have fared worse than luxuries. The ramifications of lumber shortages and high prioes are limitless and have affected seriously practically our entire population.

Obviously these lumber prices bear no relation to the cost of production and distribution. While the costs of production in the Iumber industry have at least doubled as compared with 1916, lumber prices have much more than doubled and have become wholly disproportionate to operating costs. Excessive profits have been made by the industry. The division of these profits between manufacture and distribution has varied in accordance with circumstances and the ability of the various elements in the industry to dominate the situation. That prices have been too high is recognized by the best thought in the industry, and some manufacturers have sought to stabilize the market.

The depletion of timber in the United States has not been the only cause of these excessive prices on forest products, but has been an important contributing cause. It has led to the migration of both the softwood and hardwood lumber industries from region to region and each is now cutting heavily into its last reserves. The exhaustion of timber in near-by forest regions has compelled many large lumber consuming centers to import their supplies from greater and greater distances. The wholesale priqes on upper grades of softwood lumber $i_{n}$ New York were from $\$ 20$ to $\$ 25$ per thousand prior to 1865 when mills in the same State supplied this market, from $\$ 35$ to $\$ 45$ between 1865 and 1917 when most of the supply came from the Lake States and the South, and are now entering a general level of $\$ I 30$ a thousand feet with a large part of the material coming from the Pacific coast. In the Middle West, the building grades of white pine lumber cut in Michigan, Wisconsin, and Minnesota, retailed at $\$ 15$ to $\$ 20$ per thousand feet prior to 1900 . As lumber from the Lake States became exhausted and southern pine took over this market, the retail prices rose to a level of $\$ 25$ to $\$ 35$ per thousand feet. The replacement of southern pine by West Coast timbers now in progress is initiating a new price level of about $\$ 80$ to $\$ 85$ per thousand feet. The increased cost of transportation is but one factor in these new price levels, but it is an important one. The freight bill on the average thousand feet of lumber used in the United States is steadily increasing as the sawmills get farther and farther away from the bulk of the lumber users.

Much information is available to show the disadvantages of the lumber consumer in regions whose near-by forests have been exhausted Retail prices in the Ohio Valley, for example, on certain grades exceed retail prices on the identical grades in Oregon in some instances by as much as $\$ 50$ per thousand board feet after allowing for all transportation costs. The curtailment of lumber output in the eastern regions not only has compelled the average consumer to pay more for freight but has enhanced the effects of congestion in transportation and of climatic and other factors limiting the production in regions which still support a large lumber industry. It has restricted opportunity for competition and thereby increased the opportunity of the lumber manufacturer or dealer to auction his stocks for higher prices. In other words, the effects of forest depletion can not be measured in terms of the total quantity of timber remaining. Its injury is felt particularly through the steady process of regional exhaustion. Onr remaining timber is so localized that its availability to the average user of wood is greatly reduced. Particularly does such a restricted location of the timber supplies assume a serious national aspect in the face of transportation congestion and inadequate transportation facilities such as the United States is now experiencing. IIad the forests and forest industries of the Eastern States still existed, the opportunities for regional competition in supplying the lumber markets and the wider distribution of lumber transport undoubtedly would have afforded a curb upon rising prices which did not exist in 1919.

The export trade in lumber does not have a serious bearing upon timber depletion from the standpoint of quantity, but does have an important bearing upon the duration of our limited supply of high-grade timber, particularly of hardwoods. 'The exports of high-grade oak, walnut, hickory, ash, and other woods essential to many industries in the United States which now seem probable will further enhance the shortage of such products for the domestic market and the tendencies already evident toward sustained high prices. On tie other hand, the United States imports from Canada about two-thirds of its total consumption of newsprint or newsprint materials. The effects of our export trade in lumber should be considered from the standpoint of the specific timber grades or products whose depletion is most imminent and threatening to American industries.

The concentration of timber ownership has not changed materially since the exhaustive report made upon this subject by the Bureau of Corporations in 1910. One-half of the privately owned timber in the United States is held by approximately 250 large owners, the ownership of the remaining timber being very widely distributed. The tendency toward the acquisition and speculative holding of timber beyond operating requirements has been checked, and the present tendency is toward the manufacture of large timber holdings. At the same time the lumber industry, particularly in the Western States, is going through a partial reorganization into larger operating and marketing groups. In this there is a tendency for small mills to disappear and small timber holdings to be blocked into larger ones adapted to extensive lumber manufacture. While there is still a large number of individual timber owners and of sawmills operating as separate nnits, the larger interests are acquiring a more dominant place in lumber mannfacture in the West. It is to be expected that these large interests or groups will maintain, as time goes on, a fairly constant supply of timber for their mannfacturing plants by acquiring smaller holdings. No information is at hand which would justify a conclusion that monopolistic conditions on any general scale have grown out of this situation. There are many instances to the contrary. On the other hand, the degrce of control of the timber remaining in the United States exercised by a comparatively small number of large interests will steadily increase as timber depletion continues, approaching a natural monopoly in character, and this control will extend particularly to the diminishing supply of highgrade material.

In 1918 our per capita consumption of lumber was about 300 board feet. The homes and industries of the United States require at least 35 billion feet of lumber yearly, aside from enormous quantities of paper and other products of the forest. A reduction in the current supply of lumber below this figure would seriously curtail our economic development. Appreciable increases in lumber imports are not possible except at excessive prices. We can not afford to cut our per capita use of lumber to one-half or one-third the present amount- 
to the level of European countries where lumber is an imported luxury. We must produce the great bulk of the timher which wo need ourselves and we have the resources for doing so.

The solution of the problem presented by forest depletion in the United States is a national policy of reforestation. Increased and widely distributed production of wood is the most effective attack upon excessive prices and monopolistic tendencies. Depletion has not resulted from the use of forests but from their devastation, from our failure, while drawing upon our reservoirs of virgin timber to also use our timber-growing land. If our enormous areas of forest growing land, now idle or largely idle, which are not required for any othor economic use, can be restored to timber growth, a future supply of forest products adequate in the main to the needs of the country will be assured.

I therefore most earnestly request your consideration of the practical measures proposed in the accompanying report for putting a stop to forest devastation and restoring our idle land to timber production. I would emphasize especially the immediate urgency of legislation (1) which will permit effective cooperation between the Federal Government and the several States in preventing forest fires and growing timber on cut-over lands, and (2) which will greatly extend the National Forests. Fnlargement of the National Forests offers immediate relief. On these publicly administered areas high quality timber can be grown and utilized to the maximum advantage; regrowth will follow cutting; and, under the rogulations of the Forest Service, the disposal of timber will foster competitive conditions in the lumber industry. These steps are the foundation of an offective national policy for insuring a permanent and adequate supply of timber.

Concurrently, with these measures, a comprehensive survey of the forest resources of the United States should be made. Respectfully yours,

E. T. Meredith, Secretary.

JUNE $1,1920$.

The honorable the Secretary of Agriculture.

SiR: I transmit herewith a report on forest depletion and related questions which has been prepared by the Forest Service in response to Senate resolution 311 . The existing quantities and current growth of a resource so great in extent and so widely distributed as wood can not be stated in exact terms. To obtain strictly accurate and final data on these subjects would require an exhaustive field study covering at least two years. In order, however, to present the situation as clearly and concretely as possible, I have felt it desirable to use the best quantitative data available, recognizing that much of it is hut tentative or approximate in character.

A large number of men in the Forest Service have participated in assembling and compilation; but the report is principally the work of Assistant Forester Earle H. Clapp, in charge of the Branch of Research.

Respectfully,

W. B. GREeLEY, Forester. 



\section{TIMBER DEPLETION, LUMBER PRICES, LUMBER EXPORTS, AND CONCENTRA- TION OF TIMBER OWNERSHIP.}

\section{REPORT ON SENATE RESOLUTION 311.}

The following report is sulmttted in compliance with Senate resolution 311 (66th Cong., $2 \mathrm{~d}$ sess.), introduced by Senator Capper and considered and agreed to by the Sente on February 21, 1920. The resolution provides:

Whereas it luas been reported that the forest resources of the United States are being rapidiy depleted, and that the situatton is already serious and will soon become critical; and

Whereas these alleged facts are either largely unknown to the public or are in dispute: Therefore be it

Resolved, That the Secretary of Agriculture be, and he is hereby, directed to report to the Senate on or before June 1 , 1920, on the following matters, using what Information the Forest Service now has available, or what may be obtatned readily with Its existing organlzation:

1. The facts as to the depletion of timber, pulp wood, and other forest resources in the United States.

2. Whether, and to what extent, this affects the present high cost of materlals.

\section{EFFECTS OF SCARCITY AND HIGH PRICES OF FOREST PRODUCTS UPON REPRESENTA- TIVE INDUSTRIES.}

To illustrate the general situation, the salient facts regarding a few representative industries are first presented. They are chosen because of the extent of their raw material demands, their baslc character industrially, and the way in which they touch, directly or indirectly, the life of our entlre population. They are: General building and construction, farming, the railroads, the furniture, veneer, landle, vehicle, and agricultirnl inplement industries, and the newspapers.

$A$ shortage in housing acconinodations that is almost wordIvide laas brought home vivtdly the close relation of building to the comfort, health, and general welfare of the public. When for any reason construction falls below nolmal, overcrowding, high rents, lowered standards of living, and other evlls follow. Therefore first place will be glven to a discussion of conditions in the general building and construction industry.

\section{GENERAL BUILDING AND CONSTRUCTION.}

More lumber is used in the United States for general buthing nud construction than for any other purpose. In normal years probably 28 billion board feet is used in this way out of an arerage annual cut of 40 billion.

For the five years before the war, 1910-14, the average annual building bill of the country shown by building permits was approximately $\$ 670,000,000$. After dropping to $\$ 445,549,493$ in 1918 , it rose in 1919 to $\$ 1,326,936,702$; but with building costs increased 100 per cent or more, actual coustruction did not much, if any, exceed the prewar average. Apparently all construction work in the United States is behind requircments, but the deficit is greatest in dwelling houses.

The builung permits issued in 21 citles of various slzes widely distributed over the country show that, in values, housing construction formed 36 per cent of all buliding in 1913, 21 per cent in 1918, and 27 per cent in 1919. Housing constructlon in 1913 was exceeder in 1918 in only two of the 21 cittes, and in 1919 in only 6 , in spite of the "bulld-a-home" campaign. The falling off in house constructlon generally appears to bave been par-
3. Whether the export of lumber, especiajy of hardwoods, jeopardizes our domestic Industries.

4. Whether this reported depletion tends to increase the concentration of ownership in timberlands and the manufacture of lunber, and to what extent; and if such concentration exists, how it affects or may affect the publlc welfare.

A comprehenslve and fully adequate report on these matters would require an exhaustive survey of the forest resources of the country, their ownership, the Industries dependent on them, and the general related economic conditions. No such survey has ever been made. Nevertheless, data already available or secured throw much light on the subjects of inquiry.

Depletion and the effect of depletion on prices are so interrelated that sections 1 and 2 of the resolution are considered together.

ticulariy marked since the latter part of 1919 , when the greatest upward movement of lumber prices began.

The Unted States Housing Corporation states that normaily 30 per cent of the number of buildings coust ructed are dweilings; that in 1919 dwellings were only 15 per cent; that $1,000,000$ families in the United States deslred louses even before the war; that the shortage has since increased very raptdiy; that there were but 70,000 houses butlt in 1919 , when to have met the requirements there should have been 500,000 ; and that in 1890 an average of $110 \frac{1}{2}$ families occupted 100 homes, but to-day 121 families occupy 100 homes. The construction of jouses in 1918 was less than in 1919.

A part of the reason for delayed house construction, particularly in the latter part of 1919 and in 1920, is almormally high Iumber prices. Tlıe l'ittsburgh home Jullder of 1913 patr $\$ 27$ per thousand board feet for hls No. 1 common dimension 2 by 4 framing $\$ 72$ in 1920. Sheathing lumber, No. 2 common yellow plue, cost him $\$ 26$ in 1913 and $\$ 80$ in 1920. Yellow-pine finishing Jumber increased from $\$ 42$ to $\$ 140$. If he used plain oak finish instead of southern pine, he paid $\$ \$ 5$ in 1913 and $\$ 260$ in 1920. Yellow-pine siding rose from $\$ 36$ to $\$ 120, \mathrm{~B}$ and better flat-grain flooring from $\$ 38$ to $\$ 142$. Piain oak flooring cost ill $1913 \$ 70$ per thousand feet and tn $1920 \$ 290$, and quartered oak rose in the same period from $\$ 102$ to $\$ 352$.

The total cost of houses has increased proportionately. A frame house bullt in Washington, D. C., In 1917 for $\$ 6,250$ is now being duplicated from original plans at a cost of $\$ 12,250$. A St. Paul archltect reports that a house was built for $\$ 4,240$ in 1915 , not including plumbing, heatlng, and wiring, and that a house bullt from the same plans in October, 1919 , cost $\$ 7,724$, while for identical plans in February, 1920, the cost rose to $\$ 11,820$, or 179 per cent over the 1915 price. The lumber and millwork costs in 1920 were $\$ 5,039$, or $\$ 799$ more than the total cost of the house in 1915. All of the ttems increased in 1920 over 1915, but with the exception of an insignificant item for a bond the percentage increases for lumber (304 per cent) and millwork (222 per cent) were the bighest. On a six-room frame 
house built in Washington, D. C., for $\$ 4,771.60$ in 1913 bids on identical plans in May, 1920, total $\$ 11,465.50$.

The lumber for a ready-cut, one-story, five-room house which was llster at $\$ \$ 83$ in 1915 had been raised to $\$ 3,272$ in April, 1920, a tolal increase of 270 per cent. Another company dealing in ready-cut houses listed the material for a two-story sevenroom lrouse at $\$ 1,995$ in 1915 and now lists it at $\$ 5,606.90$, an increase of 181 per cent.

Jumber prices alone do not tell the whole story. The person who builds a house faces a series of difficulties in securing his materials; delays, many of whlch enter materially into lncreasing costs; many of the grades desired, particularly the better grades, can not be sceured euslly, sometimes not at all. Very often the lumber secured is not properly dried and comparalively inferlor and unsatisfactory construction results. Thls situation, combined with delays in securing materials, labor difficultles, etc., makes the construction of a dwelling house a lighly uncertain and speculative venture, takes it entlrely out of the rench of large numbers of people, and leads to a gradual lowering of standards of living. Classes of Industrial construction which can go forward regardless of uncertainties and costs are able to pay lumber prices which the ordinary home builder can not afford and increase the element of speculation in the business of building bouses for sale or rental.

\section{FARMING.}

Farms consume a very large aggregate of construction lum. ber. Cheap high-grade building material aided powerfully in the rapld development of farm lands. The Middle West, for example, was built up largely with the output of white pine lumber from the Lake States. In the eighties first quality white pine lumber such as can now hardly be found in any market in the United States commonly retailed throughout the Mlddle West for $\$ 15$ to $\$ 20$ per thousand feet. In February, 1920, the farmer in Kansas paid $\$ 70$ per thousand for yellow pine framing and about the same for Douglas fir. For No. 2 common lumber suitable for temporary sheds and rough construction, either fir or southern pine, he paid \$72.50. $\mathrm{B}$ and better yellow pine finishing lumber for house construction cost \$147.50. Silo stock cost $\$ 185$.

To ascertain the effect of present lumber plices and shortages upon the farming Industry, questionnalres were sent to a large number of agricultural county agents einployed cooperatively by the Federal Government and the States in 33 States lylng east of the Rocky Mountalns, and similar questionnalres were also sent to a large number of retall lumber dealers supplying country trade in seven Middle Western States.

County agents throughout practically this entire territory report a marked suspension in new construction and even in farm improvements and repalrs requiring lumber. Out of some 250 counties In 32 States only about haif a dozen agents reported more building than in the past. New building is reported as going on normally or in excess of normal in only 10 out of every 100 counties, and this in regions of exceptional prosperity. In the Prairie States, from Ilinois north and west, repairs are reported by iumber dealers as deferred to an extent of about 32 per cent, and new construction as somewhat less than 50 per cent of normal. The average yearly amounts of lumber sold per yard in farming districts of Nebraska and Kansas were slightly more in 1919 than in 1917 or 1918, but below the prewar average of $\mathbf{1 9 1 0}$ to $\mathbf{1 9 1 5}$. The widespread deferment of building is almost unlformly laid to a combination of hlgli lumber prices and shortages of labor.

Lumber dealers for severai of the Middle Western States leport lumber stocks on hand as above normal. Whis is to suard against delayed shipments, to be able to supply anticipated increase in demands, etc. Apparently throughout much of the region covered supplies could usually be secured in the desired amount and quality if priees could be paid. Iocally, however, the pronounced changes In lumber distribution of the last year have apparently made it difficult to secure desirer materials and qualities wilhout delay. The difficultles were greater witls the better grades luan with common lumber, and they oceured even in the heart of the manufacturing district in the South, because of axcessive demands and competition for this class of material.

An attempt was made also to get at normal and probable future lumber requlrements of the farming Industry. The estimates of county agents indicate an average amual utillzation per farm unlt of about 2,000 board feet. For practleally the entire region covered an Inereased future demand for lumber is predicted in order to take care of improvements looking loward better equipment and improved living conditions, provision for increasing population, and the developinent of new farm units. This is important, in the face of falling lumber production In all parts of the country except the extrene West.

lighty per cent of the county agents report that the extremely high prices of lumber are placing a handicap on farm development and the production of crops and live stock. The most serious effect reported appears to prevail throughout the sparsely timbered regions, where in cases of emergency the farmer is not able to secure supplies from the farm woodland. Jive-stock raising and dalrying seem to be the hardest lit, bceause of the large barn ejulpment and shelter necessary. It is repolted that lieavy losses of implements and crops are lesulting from lack of proper storage facilities. In some of the newer sections it is even reported that farmers who have not yet reached a stable financlal basis are leaving the land because of the cost of new construction. It is reported from all parts of the territory covered that present conditions are tencling to lower the standards of living and to make it more dlfficult to hold on the farm the farmer's own children and desirable classes of labor.

\section{THE RAILROADS.}

The normai demand for railroad ties is somewhere between 100 million and 125 million annually. In 1918, however, purehases were slightly under $77,500,000$ and In 10 months of 1919 were slightly orer $84,500,000$. During the wal and the period of Goverument supervision of the railroads extensions could not be made, and improvements were necessarily confined to those of an urgent claracter. Lumber purchases were therefore at a minimum. Even under such a policy of retrenclument railroad purchases of sawed materials, exeluding lyewn lailload ties, telephone poles, etc., aggregated approximately $4 \frac{1}{2}$ ibllion feet, or 14 per cent of the total lumber cut of the country for 1918 .

That there have been profound clianges in the Jumber dlstribution from different regions during the past year is shown by the Invasion of the Middle Western and Eastern States by Douglas fir ties. These are regions which in the past have bern supplied with the standard oak tie cut immediately along the rlghts of way or with southern pine ties from the South. During 1919 order's amounting to nearly 100,000,000 board feet were placed for Douglas fir ties for eastern roads because of the uncertainty of securing adequate supplies along their rights of way and because of the excessive costs of local ties. Douglas fir ties are now said to be costlng eastern roads from $\$ 1.75$ to $\$ 2$ each at thelr treating plants or on their rights of way. In other words, oak ties cut within a few miles of the right of way and bearing practically no charge in freight and soutlern pine ties are now being replaced by fir ties hauled overland across the continent or shlpped through the Ianama Canal.

To supply their general lumber requirements the railroads liare obvlous advantages in the purchase of lumber from mills along thetr lines, and increases in prices hare been far less 
pronounced than for otber Industries. During the last four years, howerer, the cost of lumber purchased has almost doubled, while the amounts have been reduced. Under the great financial burdens of readjustment and recoustruction following the war added costs of any important material delay even the most needed repairs and betterments and add to transportation difficulties, which react upon all industries and consumer's. Uncertalnty as to securing adequate supplles of desired inaterials at the time wanted has made it necessary for railroad companles in general to hold comparatively large surpluses, a tendency which serves to accentuate shortage for all purchasing industries. Railroads operating in the forest regions ordinarily carried a few years ago but from one to two weeks' supplies, since stocks could be replentshed quickly. Other roads carried stocks sufficient to last several months. 'The timber roads are now carrying from 6 to 10 weeks' supplies and other roads sufficient to last from 6 to 9 months.

\section{THE FURNITURE INDUSTRY.}

The furnlture industry is one of a group of industries which utillze muinly high-grade hardwoods and have had much the same history. They began in the Northeast, where for many years the local supplies were ample for their needs. The wanlng of these supplies forced the industries westward, where they rapidly expanded in the last quarter of the nineteenth century, drawlng mainly on the magnificent virgin hardwood forests of the Middle West. Within the last 15 or 20 years they have been forced to turn more and more from the depleted and vanishing stands of the States along the Ohio to the timber northward and southward. Their present sources of supply are very largely the remoter and more lnaccessible portions of the Southern Appalachians and the lower Mississippl Valley. When these forests are cut out the industries will have exhausted practlcally their last large resources of old-growth timber.

Besldes furniture the group includes the veneer, handle, vehlcle, and agrlcultural-1mplement industrles. These all compete among themselves for raw material.

Before the end of the summer of 1919 the demand for furniture had assumed such proportions that the normal production of the large factories during the current season had been almost wholly contracted for, with many retallers uncared for. The immediate result was a corresponding demand for lumber on the part of the furniture-manufacturing industry, which normally uses abotat 11 billion feet, and is the largest consumer of high-grade hardwood tImber in the United States. Hardwood lumber stocks following the war were low and have since gone to as low as half the normal; production has fluctuated downward to a minimum, in some districts of as low as 50 per cent of normal, so that it has been the practically universal experience of furniture manufacturers that desired supplies of raw material could be secured only with the greatest difficulty, particularly durlng the past six months.

The veneer situation has been equally bad; orders for sawn oak veneers are said to be 100 per cent greater than stocks, and sliced and rotary veneer equally difficult to secure. For this and other reasons production of furniture, in the face of unprecedented demands, is from 15 to 25 per cent below normal, and many factorieś face slut downs because of inability to secure raw materials. Individual furniture manufacturers bid against each other for the inadequate supplies of lumber and veneer available, while thelr Industry competes with the automobile, musical instrument, and other manufacturers simllarly situated. The only factorles which are not having serious trouble in gettlng wood supplies seem. to be the small plants which can get local timber and which make comparatively low-grade furniture.

Difficulties have been aggravated by lack of facilities in both the lumber and the furniture industrles for artificial drying of wood. In prewar practice hardwood lumber was ordinarily alr seasoned for six to nine montlis before sale. Furniture dealer's are now purchasing materlal practically green from the saw, involving heavy additional freight charges. While the uncertainty as to securing material and the need for a long drying perlod justify the carrying of larger stocks at the factory, it is reported that furniture manufacturers have on the average only about one-lialf of the stocks carried before the war. Supplies have been so limlted and uncertain that lumbermen have refused to take contracts for their output at any specified price and have even refused to give buyers an option on any stated amount of lumber at market prices on delivery. Competition has become so keen that buyers have been ordered to secure lumber almost regardless of price.

Naturally prices have fumped under such competition. While there has been an increase during the past four years in practically every ltem entering into furniture production, the largest inerease has been in the cost of lumber. Roughly, lumber costs increased about 200 per cent luring the year 1919, and a total of 300 per cent since before the war. Something like 75 or 80 per cent of the law material for furniture manufacture is lumber or plywood. Arerage prices paid by furniture factories on No. 1 common 4/4 red gum were in January, 1916, approximately $\$ 27.50$ per thousand hoard feet; in Apull, 1919, $\$ 49.50$; and in April, $1920, \$ 170$. No. 1 common $4 / 4$ sap gum rose from $\$ 24$ in January, 1916, to $\$ 95$ in April, 1920. No. 1 common $4 / 4$ plain oak, anotlee wood largely used in furniture making, during the same perlods increased from $\$ 37.50$ to $\$ 160$. Quartered oak, firsts and seconds, $4 / 4$ increased from $\$ 90$ in January, 1916 , to $\$ 310$ in April, 1020 ; and No. 1 common $4 / 4$ basswood, from $\$ 29.50$ in January, 1916 , to $\$ 125$ in April, 1920. Wholesale veneer prices have lisen in proportion; between January 1, 1916, and April 1, 1920, 3 inch gun tncreased from $\$ 16$ to $\$ 60$, $\frac{1}{20}$ inch and $\frac{1}{24}$ inch gum, from $\$ 4$ to $\$ 16$; 1 inch poplar, from $\$ 16$ to $\$ 65$; and quartered white oak on the ave:age, from $\$ 17$ to $\$ 52$ per thousand square feet.

Higher lumber prices are multiplied in retail prices of furniture. This may be lllustrated by a single example. The lumber for a medium quality plain dresser cost $\$ 2.72$ in March, 1919, while in February, 1920, the same matevial cost $\$ 7.65$, an increase of practically $\$ 5$. Dealers are reported to add usually from 75 to 100 per cent to the factory price to cover their own selling costs and profit. An lncrease in lumber cost to the furniture manufacturer of $\$ 5$ adds from $\$ 9$ to $\$ 10$ to the retail price, and the purchaser of the dresser actually pays for the lumber which goes into it three or four times prewar prices.

Such conditions as have existed during the past year-and the lumber situation has been a material factor in this-have infected a very large speculative element into the furniture industry. In many cases the furniture maker is not sure of his lumber or what it will cost until the time of lts delivery. He can neither plan future output nor estimate future costs. He safeguards his own interest through higher prices to the retail dealer, who, in turn, can be certain neither of the filling of orders nor of the cost of his stock until delivered. All of this uncertainty and speculative character encourages, and to some extent necessitates, increased prices all along the llne, including finally the price to the consumer, who pays not only for increased costs but for business risks. Furthermore, purchasers, since they must pay high prices, demand high-grade furniture; and this, together with the widespread disappearance of local tlmber supplies, makes more and more difficult the position of the small factory producing comparatively lowpriced furniture, and tends to centralize manufacture in the larger concerns.

\section{THE VENEER INDUSTRY.}

Veneer manufacture is a rapidly growing industry which supplies furniture makers, manufacturers of musical Instruments, 
the automobile Industry, box makers, etc. For high-grade veneer havdwoods are used almost exciusively. The industry consumes annually the equivalent of about 780 million board feet of hlgh-grade materlal, the bulk of whlch can be secured only from virgin stands. The demand among hardwoods is chiefly for red gum and, second, for white oak. One section of the industry, which uses sucl northern hardwoods as maple, birch, and basswood, is localed in the Lake States. As In the case of many other hardwood-using Industries, the veneer industry has for some ycars been centered mainly in the Mlddle Western States. Supplies, at first local, are now largely in the South, and the main demand has been transferred from oak to gum.

The veneer situation is similar to that described for other forest products-short supplies, abnormal demands, and competition, in this case among sucb consumers as phonograph makers, manufacturers of other musical instruments, the automoblle lndustry, and furniture manufacturers. As indicated ln the preceding discussion on the furniture industry, wholesale veneer prices have increased from three to four times between January 1, 1916, and April 1, 1920.

Log prices have risen in proportlon. Indiana white-oak logs, 20 inches and over in diameter, have increased during the same period from $\$ 75$ to $\$ 200$, and flitches from $\$ 100$ to $\$ 300$ per thousand board feet.

In general, there is only one-fourth of the normal supply of reneer flitches and logs ln siglit. Practically tile only firms not expcriencing extreme difficulty in securing supplies seem to be those factories which can still obtain local tlmber. In a few agricultural reglons reserve stocks in farmers' wood lots liave been drawn out by the current hlgh prices. The scarclty of logs has compelled some factories to close down. Veneer and ply-wood production, while nearly normal in September, 1918 , had fallen approximately to 80 per cent between January and March, 1919, to 60 per cent in November, to 50 per cent in December, and is now estimated at not over 40 to 50 per cent.

The veneer lndustry requires high-grade material. It takes practically clear logs, generally 16 inches and more in diameter at the small end. The lndustry must, for its higher-grade products, depend very largely upon the fine old timber found al. most entirely in virgln stands. The general depletion of hardwood stands has made the industry, along with many others which accept only high-grade material, prlmarily dependent upon the only reserve of vlrgin hardwoods of any extent-the southern Mississippi Valley. Here logglng operations have been seriousiy handicapped by adverse weather and other conditions, and as a result log supplies for the industry as a wlole have falien off 75 per cent. Veneer and ply-wood production have fallen off 50 per cent, wholesale prices have gone up from three to four times, and manufacturing concerns in the same and competing industries are bidding frantically against each otber to secure the inadequate supplies of veneer stock available in order to meet their current demands. The consumer pays the full bill of Inereased $\log$ and veneer prices, and undoubtedly more, in the advancing prices charged for final products.

\section{THE HANDLE INDUSTRY.}

For the high-grade hickory and ash requlred by the handie industry no satisfactory substitute has yet been found, and these two woods make up about two-thirds of the total used. The supplies now come mainly from the South. Here the most accessible timber bas been taken. The few large concerns maintain large and expensive organizations, which literally comb the country to secure materiai. More and more it is becomlng necessary to work into the districts remote from transportation facilities. Practicaliy the entire territory within which hickory is found in commerciai quantities is thus covered.
In the case of asl the sltuation is said to be even more serious. The industry has prefered the denser northern upland ash for handles. The swamp-grown ash of the Mississippi bottom lands has a smaller percentage of the dense material and has been less sought up to the present time. This has greatly limited the area from which tlie wood has been secured. Ash in sufficient quantlties to support the handle and other competing industries is practlally gone, therefore, from the Middle Western States north of the Olio. It is predicted by one man thoroughiy familiar with condltions that five years more will practicaily see the finisls of ash timber in any quantity in this section.

The demand for ash and hlckory handles is so great that manufacturers can not meet requirements. The export demand is said to be even greater than before the war and American handies are being slipped to all parts of tlie world.

Arelage prices of handle material are practically unobtainahle because of the great variety in which such material is purcilased-logs, bolts, dimension sizes (split, hewn, and sawn), flitch, and plank. While prices quoted are from two to three times those which obtained before tlie war, manufacturers state that in practice they are paying any price necessary to get supplies. They find themselves in active competltion with other lndustries requirlng hlckory and ash, and particularly with the manufacturers of automobile wheeis.

Arerage wholesale prices of standard size hickoly handles 36 inclies long have adranced from $\$ 1.20$ per dozen in 1916 to $\$ 2.50$ per dozen in 1920 . Retail prices, which were from 25 to 30 cents per handle in 1916 , are now 50 cents.

One of the effects of the exhaustlon of local timber is the gradual elinination of the small liandie factory. When timber can no longer be secured locally, the only source of clieap supplies, large organizations become essential in order to cover a large territory. Without the necessary capltal for this the smali concern must give way to the large manufacturer. There Is said to be a steady drift toward concentration of handle manufacture by large concerns and the disappearance of local industries.

\section{THE VEHICLE AND AGRICULTURAL IMPLEMENT INDUSTRIES.}

The vehlele and agriculturai-lmplement industries compete for hicikory and ash with the handle industry, and in addition use other hardwoods, such as oak, for which they must compete with such industries as the furniture makers. They are located mainly in the Middle West, but now derive most of their wood supplies from the South. A number of far-sighted organizations are said to have purchased more or less extensive hardwood tracts some years ago, from which they are now able to draw their wood supplies in part at least. For the remainder they depend on outside purchases.

To secure hickory, which occurs scatteringly over large areas, the vehicle and agricultural-lmplement industries ordinarily maintain extensive buylng, logging, and milling organizations in the South. They draw upon every conceivable sourcefarmers' wood lots, small mills, large sawmllis, and even speclalized operations designed to secure hickory aione.

These concerns in generai carry in stock about a two years' supply of special-dimension stock. Hardwood lumber prices have now gone so high that a number of them are making purchases in the open market only when prices do not exceed a prescrlbed maxlmum, and amounts secured have fallen to about one-quarter of their utilizatlon. These industries have found in the case of farm implements that it is impossible to lncrease the prices of their products beyond a certain point without a marked falling off ln sales. The result is that the material in the open market goes to the industries whlch are able to pass increased costs on to the consumer. Anotlier result has been the withdrawal from the field of a number of purchasing organizations. 
I'ractically the only case in the vehicle and Implement industries li which the scale of buying has not been reduced is for automobile wheels and other automoblle purposes. Here demand absorbs all the supply, is constantly becoming greater, and as yet there seens to be no limitation as to price. Makers of antomobile wheels say that they can still get the material required th they make sufficient effort and pay the price, but it is necessary to go farther and farther away for it. A very careful analysis of cost data by one concern shows that the largest element in recent cost increases is securing special stocks such as hickory from remote and inaccessible regions.

The preceding discussion applies particularly to the large concerns. Small factorles without large organlzatlon and outside connectlons for securing supplles are laboring under more serious difficulties, through the Interruption of normal channels of alstribution.

Material is secured practically green. Nelther the lumber nor the vehicle Industry is adequately equipped with kllns or the trained personnel to kiln-dry the refractory hardwoods in the large sizes used. Excesslve losses, in some cases running as high as 40 per cent of the material and even hlgher, are reported. Thls is merely another phase of the situation hardly known outslde of the industries most directly concerned, growing directly out of a shortage of supplies and aggravating the shortage still nore.

'The many inquiries received by the Forest Service from vehlele and Inplement makers asking for information on possible substitution for the woods used in vehlcle making is merely another indication of the difficulties in getting supplies at the present time, and of uncertainty as to the future. Because of the troulile and uncertainty of securlng hickory and the rapidly increasing prices, vehicle manufacturers are substituting steel where possible, even though this Involves still bigher prices.

\section{THE NEWSPAPERS.}

High prices and serious difficulties as to supplles are by no means confined to lumber. The newsprint situation has been very much in the foreground, particularly since the mlddle of 1919. I'ractically the only newspapers in the Unlted States, from the large metropolitan dailies to the small country newspapers published weekly, which have not experienced serious difficulties are those having long-term contracts or those fortunate enough to produce their own newsprint.

Under prewar condltions newsprint paper - was contracted for on a yearly term basis at $\$ 2$ a hundred pounds or less. Coutract prices during and slnce the war have risen to $\$ 3.50, \$ 5$, $\$ 6$, and at the present time even to $\$ 7$, and it has been reported that 75 per cent of the existing contracts provide for a price readjustment at the end of every three or six months. Prewar prices included freight; present prices do not. Few newspapers are now able to contract for theil entire requlrements. The smajier newspapers entirely and the larger papers to a very materlal extent must now depend upon the spot market, in which the full effects of competition for an inadequate supply are felt. In such competition there is full opportunlty for speculation. Prewar spot market prices of about $\$ 2$ bave risen rapIdly, particularly since January, 1920, until now sales reported at $\$ 15$ as a maximun, and even higher rates are predicted. At $\$ 15$ the paper alone for a 32-page newspaper would cost $7 \frac{1}{2}$ cents. One eastern newspaper, with a consumption of 6,000 tons, has estlnated that its 1920 paper bill will be $\$ 72,000$ in excess of that for 1919. A western paper estimates that its 1920 paper blll will be $\$ 450,000$ more than that for 1919 .

The cost of newsprint is said to be from one-third to onehalf the total cost of the entire newspaper. To meet increased costs publishers must increase revenues either by raising subscription prices or advertising rates, or accepting more advertisIng. The acceptance of more advertising means either the use of more paper or the eliminatlon of reading matter. The ratlo of reading to advertising matter before the war is said to have been about 60 to 40 , and it is reported that this ratlo is now reversed. Some Increases have been made in subscription rates, but the chief source of larger returns has been through more advertising and higher advertising rates. The newspapers which have not been able to Increase the amounts of advertising and advertising rates have been hard hit. Advertising rates during the past year have risen 35 per cent or more. Increased advertising costs, deslgned partly to pay increased operating expenses and partly to reduce newsprint consumption, are passed on to the consumer.

Newspapers have been drlven to extraordinary measures. Advertising has been refused. One New York paper is reported to have refused six pages of advertising for a single issue. Another New York paper is reported to have refused for a single issue advertising whlch would have returned $\$ 14,000$. Attempts have been made to eliminate waste, and the size and number of editions have been cut. Features have been curtalled or eliminated, the proportion of advertising to reading matter has been largely increased, and efforts to increase circulation lave been suspended.

Unfortunately the situation Is generally regarded by the public as a whole as one which can be easily remedied withln a few months, and it is not reallzed that the life of the pulp and paper Industry in the regions of its present development Is absolutely dependent upon rapidly failing timber supplies, while hittle or no effort is being made toward their perpetuation.

\section{THE SITUATION SUMMARIZED.}

If the Industries considered are representative of general conditions, and there is every reason to belleve that they are, the lumber situation of the past few months has, for many industrles and many classes of consumers, been one of serious shortages of supplies, of great demands, and of uncertainties in securing satisfactory amounts of desired materlals. Rapldly rising prices have reached the hlghest points that have ever been known for lumber and for practically every other forest product consumed in the United States. Market conditions have been unstable, and it has been impossible for many consumers to plan with any certainty on cost of materials. The output of industrles which depend upon lumber and other wood products has been very much reduced, and in an extreme case has gone as low as 50 per cent of normal.

The entlre nature of competition in the case of forest products has changed. Prlor to the war the producers of lumber, newsprint paper, and other forest products competed with each other for business. Competition during the past few months has been very largely among consumers for generally inadequate supplies. Under any conditions such a reversal in the fundamental sltuation would result in hlgher prices; but the shortage and demands have been so extreme that wholesome restraints as to prices which mlght safely be pald have been removed, and in many cases it has been possible to pass on to the consumer, and even to augment, almost any lumber price increases. This has not been universally true. There has been some difference between industries in the extent to which they could go. Apparently limitatlons have been felt more by industries producing the necessities than by those with products which fall rather in the class of luxuries.

The furniture naker finds himself handicapped in competing with the maker of musical instruments. The manufacturer of agricultural implements withdraws his buying and manufacturing organizations from the field because he can no longer compete with the manufacturer of automobile wheels. The large and well-financed organizations, able to draw their supplies from distant sources, have fared much better than the small manufacturer with limlted capital who must secure his 
law material locally. Unfortunately, in most cases it is the local supplies which have been most depleted, and the existing situation has tended to eliminate much more rapidly than in normal times tire small coneern in the best position to supply cheap products.

With uncertainty as to supplies, with equal or greater uncertainty as to the costs, and with almost frantic bidding between members of the same industry and between different industries for materinis, a iarger speculative element than has ever before been known has been introduced into the sale of lumber and its further manufacture. This, again, has increased prices to the uitimate consumer, and in extreme cases, such as dwelling houses, has removed the possibiiity of purchase from large classes. Many Industries which were operated on a comparatively stable sas under prewar conditions now find themselves upon an uncertain and highly speculative basis.

Other changes which are mucb less known, but almost equally bad, might be mentioned. One will suffice. The hardwoodproducing industry commonly held its atocks for several months or a year for seasoning. Consuming industrles commonly carried in stock supplies sufficient to meet one or even two years' requirements. When material was needed it was already seasoned for manufacture. Artificial methods of drylng were largely unnecessary and neither equipment nor personnel was provided. Growing out of the conditions described, a very great increase in artificial drying has become necessary; and this has been accompanied by difficultles in securing an adequate number of kilns and great losses in initial kiln operating, sometimes reaching 40 per cent or even higher and aggravating the shortage.

Enough examples have been given to show the almost limitless ramifications through which shortages and high prices of forest products reach the public. The building industry, agriculture, the railroads, the press, house furniture, tools-these and their like concerr our entire population. Shortages and high prices, accordingly, seriously affect the whole Nation.

With a realization of the existing situation with respect to representative industries and classes of consumers, the facts as to depletion and prices acquire greater significance, and it is possible to analyze to better advantage the fnctors which are responsible. The discussion falls logicaliy under two heads:

1. The abnormal conditions winich have affected the forest industries and their products along with all other industries and commodities.

2. The cumulative effect of forest depletion, both in the country as a whole and in the more important timber regions.

\section{ABNORMAL CONDITIONS IN RELATION TO PRESENT SCARCITY AND HIGH PRICES.}

The principa' effect of the war upon the lumber industry was to reduce the stocks available for ordinary purposes, through curtailment of production and through the diversion of large quantities of timber to special war uses. War requirements led to the placing of large orders for unusual sizes and dimensions for such products as Army wagons and wooden ships. Througin Government regulation of transportation, of the use of capital, of new construction, and even of extensions and repairs, ordinary distribution was practicaliy discontinued before the signIng of tire armistice. The lumber cut of the country fell from a prewar average of around 40 billion feet to a reported cut of oniy a little more tian 33 billion feet in 1917 , and of less than 30 billion feet in 1918. A rery considerable proportion of this material, as previousiy indicated, was utilized for essential war purposes.

Surplus woods and mill labor, sklled and unskilied alike, was rapidly drawn into other industries or Into the fighting forces. In addition the lumber Industry found itself in competition for labor with other industries producing war essentials. By the time of the cessation of hostilities a very considerable percentage of the labor ordinarily employed in lumber production had been diverted and scattered. Lumber stocks at the mills and those in the wholesale and retail yards of the country were very short and badiy broken. The industry, therefore, came out of the war more or less disorganized as to labor, production, stocks, and markets.

Following a period of great uncertalnty on the part of the public, as well as of the industry, as to possible developments, the demand for lumber began and rapldiy grew far beyond any anticipation. The shortage of houses was already serious in the United States at the beginning of the war. During the war it became very much worse. Without any stimulus whatever the demand for dwelling houses would have absorbed large quantities of lumber. The "build-a-home" movement was fostered by the Federal Government itself.

Industrial construction had during the war also falien far behind the growing demands of the country. Railroad purchase for repairs had necessarily been held to a minimum and extensions had practicaliy been eliminated. The growing freight requirements of the country necessitated large-scale betterments and material extension. Similar demands had piled up during the war in practically all of the industries which use lumber.
This accumulated demand soon absorbed the short stock available, and iumber manufacturers were overwhelmed with orders.

The Jumber industry found itself unable to increase production rapldiy. The output in 1919 was below normal in all the principal lumber regions of the country, with the possible exception of the South. In many of the former regions of large lumber output, the Lake States, New England, New York, Pennsylvania, and the Southern Appalachians, the timber is so largely gone that there was little opportunity for material expansion in cut to meet abnormal demands. In regions with timber reserves other factors have heid the cut down.

In the southern pine region bad weather hampered logging uperations during the latter part of 1919 . Precipitation was far above the average. This reduced the $\log$ production, and even caused shortages which compelied many mills to run on part time. During the first 11 montlss of the year 135 subseribing mills reported to the Southern Pine Association a totai loss of 80,213 hours, or approximately 60 working days each, 41,878 hours or 31 working days each, being due to $n$ shortage of logs. On the basis of normal production this loss represented a decrease in production for the $135 \mathrm{mills}$ of nearly $600,000,000$ feet.

In the southern hardwood region weather condltions have been unfavorable since the fail of 1918. In the fall of 1919 the conditions, already very bad, became much worse, and effective logging or in some cases any logging has become practicaliy impossible through repeated rains and floods. No1mal log deliveries for one group of hardwood mills in October and November, 1919, were but one-third of the quantitles delivered durlng the same months in 1916.

Some of the labor drawn away from the lumber industry during the war preferred other employment and remained in the towns and cities or in other sections of the country. It is estimated that southern pine operators were confronted with an average labor shortage of 20 per cent, and in many other lumber-producing regions operators found themselves unable to secure and hold full crews.

The industry has been obliged to pay higher wages and grant shorter hours, and has possibly suffered from decreased efficiency. In the case of one operation in the South it required 23 man hours in July. 1914, to produce 1,000 board feet of lumber; while in July, 1919, it required $37 \frac{1}{2}$ man hours. Again, in July, 
1914, it required 134 men on the payroll to maintaln a full crew of 100 men per day, while in July, 1919, 153 men were carried to maintain the same sized crew. Many operntors in the Appalachian hardwood region say that they hardly know from lay to day whether or not their mills will run. Illustrations of this character could be multiplied almost indefinitely for all parts of the conntry, but those already given sumiciently indicate the general situation. The unstable claracter of the lumbor industry has been in no small degree responsible for its inability to secure and hold a desirable class of labor, particularly in logging.

Depenclence upon the South and the Northwest for timber has piaced a greater hurden upon the railroads of the country than they could carry under the disorganization following the war. The car shortage is estimated by various authorlties at from 200,000 up. It is reported from the southern hardwood territory that only 60 to 65 per cent of the cars required for logs and lumber can be obtained. The secretary of the Californla Sugar \& White Pine Co, a sales organlzation which served 35 mills in 1919 , reports materially curtalled shipments in September, October, and November, due to a car shortage of 05 per cent. While the railroads do not altogether agree as to the extent of the shortage, it is certaln that difficulties in securing car's, freight congestion, and embargoes liave all served to accentuate difficultles in securing lumber supplies. Lumber, as one of the most bulky commodities, is always one of the first to suffer in case of freight congestion.

A disorganized industry, short stocks, abnormal demands, and reduced production have all contributed to high prices for lumber. Even though it had still been possible to produce lumber in quantity in each of the regions from which it has been so largely depleted-New Lngland, New York, Pennsylvania, the Lake States, and the Southern Appalachians-lumber prices would still have risen in response to other conditions which have grown out of the war. Price increases for other commodities are significant in this connection. As shown by the Department of Labor statistics, the prices for all commodities had, considering the year 1890 as 100 per cent, risen to
250 per cent in January, 1919, and to 293 per cent tn December, 1919 , with an average for the year of 263 per cent. Using 1913 as 100 per cent, prices for January, 1919, had risen to 203 per cent, and in December, 1919, to 238 per cent. Regardless of every other conceivable condition, a very substantlal rise in Inmber prlces would have been inevitable from such causes as the enormous credit expansion growing out of the war and the accompanying currency inflation, eauses whlch are responsible for large price increases in all other commodities. It is unnecessary to dwell upon these general causes, but they must be taken fully into account in any attempt to analyze the extent to which timber depletion is responsible for price increases.

Abnormal conditlons affectlng forest products have not obtained alone in the case of the lumber industry. One further example, that of newsplint, wlll be given. Because of war requirements, newsprint paper production suffered less than lumber. The Industry was less disorganized and the response to incleased demand was much more prompt. 'The Federal Trade Commission reports that newsprint production during the fiscal year 1919 exceeded that of 1918 by 8 per cent. Prewar production had reached $1,313,284$ tons in 1914. Durlng the 20-year period preceding the war the demand for newsprint had increased practically without a break by 200 per cent. Incldental to the increase In demand which might have been expected normally there grew out of reconstruction the most extensive use of advertising which the United States or possibly any country has ever seen. Within the year national advertising increased greatly. Advertising as a whole in 1919, as shown by nearly 100 newspapers in a little less than 20 of our largest cities, increased over that of 1918 by approximately 40 per cent. During the first two or three months of 1920 the amount of advertising exceeded that for a similar period in 1918 by something over 50 per cent. This demand created, in spite of the restriction of reading matter by the average newspaper, an abnormat demand for paper and was a powerful factor in the unprecedented rise in newsprint prices which has already been discussed.

\section{STEADY PROGRESS OF FOREST DEPLETION.}

\section{FOREST DEPLETION AND MIGRATION OF THE LUMBER INDUSTRY.}

Each successive chapter in the history of the lumber industry in the United States has been a story of depletion and migration. In softwoods it is a history of regional industries, each developlng in its turn, dominating the consuming markets of the country, and declining at last so far as to be unable to meet the local requirements of its region. Each has bad the same essential features of beglnning, rise, and fall from light culling operations to clean cutting of good timber and poor alike and of the shifting of cut from the more to the less desirable species. 'The story of each region wlll be taken up in detail, but the main outllues should first be made clear.

In New England lumbering early became a lcading industry, supporting local needs, furnishing the basis for the early shipbuilding industry, and providing exports. The Industry expanded very slowly, and owing to the shifting of the cut from nile section to another, from one specles to another, and finally from virgin stunds to second growth, partly on deserted farm lands, production did not reach the maximum until as late as 1907. Since then it has been falling rapidiy.

New York followed New England as the center of softwood Iumber producton and was the leading lumber State in the country in 1850 , although the greatest volume production was reached from 10 to 20 years earlier. Pennsyivanla followed New York, and led all the States in 1860 , but has now declined until one city district consumes more than the total lumber cut of the State.

White-pine operations in the Lake States began with a single sawnill in 1832; eastern shipments were being made three or four years later; and the cuimination was reached in 1892 with a cut of nearly 9 bitlion feet. Dreary wastes, dismantled savmilis, deserted towns, and an insignificant pine output of a single bllition feet in 1918 are depressing reminders of the day when Lake States lumber supplied the markets of the country from the Rockies to the Atlantlc Ocean and from the Cunadian boundary literally to the Gulf.

The great development of the southern industry began in the seventies and Increased rapldy to what was probably the maximum, about 16 billion feet, in 1909 . In its turn, southern pine dominated the markets little if any less conpletely than white pine; but the South is foliowing the course of other regions, and the remaining supplies of virgin pine are only about one-fifth of the original stand. Within a single decade southern pine production promises to exceed by little, if any, the needs of the Sonth.

A great start has been made in the last chapter of the history of virgin softwood stands. Since 1894 Pacific coast and Rocky Mountain timber hus been forclng its way increaslngly into the mldd we wern and eastern inarkets. Within the year it has dominated those of the Lake States-and has even entered in appreciahle quantities those of the South itself. To the West only, of all our heritage of magnificent softwood forests, can 
the country look to an increasing cut; but even here there-are alreadly local evidences of depletion, warnings that the conclusion of the story will be the same as that of other regions and in far less time than has been estlmated.

Hardwood depletion and the migration of centers of production has followed along much the same line, although reglonal boundaries have been much less distinct. Cuttlng began early in New England and along the Atlantlc coast, spread slowly to the westward through New York and Pennsylvania as local supplies were cut out, and became important in Ohlo and the Middle Atlantlc States after water and rail transportation was developed. From here if spread north into the Lake States and south into Kentucky and Tennessee and the southel'n Appalachian Mountalns. The stands of these various regions have been successively depleted. In New England and New York, aside from second growth, largely in farm wood lots, there remaln only the stands of hardwoods in the North. The conmerclal cut of the Middle Western States is almost a thing of the past. That of the Lake States has fallen off materially, as has also even that of the southern Appalachians. The end of the cut in the Appalachlan States is pretty definitely in sight. The only reserve of Importance is the soutbern Mississippi Valley, and even here it is doubtful if future production will for any length of time materially exceed the average output of the last few years.

\section{BASIS FOR DATA.}

Before taking up the varlous tlmber regions ${ }^{1}$ the basis for the data used should be given. It should be recognized that thoroughly reliable data on sucl subjects as the remaining stand of timber, its quality, rate of growth, and extent of depletlon, and on the forest areas of different classes, can be obtalned only by a thoroughgolng timber survey requlring two or more zears. Nothing of this character has ever bcen attemipted in the United States.

More has been done In estimatlng the amount of saw tlnber than on any other of the subjects mentioner: The most comprehensive data on timber stand were secured by the Bureau of Corporations. A part of the country only was covered for timber of saw-tlmber size, and such questions as the volume of materlal below saw-timber slze, extent of depletlon, rate of growth, the requirements of our industries, etc., were not included. Other available data have covered this and other

Higure 1 shows diagrammatically the more or less arbitrary State groups which are used in part for statistical purposes oniy. It shows aiso the principal saw timber scctions of the United States. The regions of the discussion do not follow either consistentiy, but the arear included in each are indicated in the text. The State groups used are made up as follows:

New England: Maine, New ilampahire, Vermont, Maasachusetts, Rhode Island, and Connectleut.

Middle Atlantic: New York, New Jersey, Pennsylvania, Delaware, and Maryland.

Lake: Michigan, Wisconsin, and Minnesota.

Central : Ohlo, Indiana, Illinois, West Virginla, Kentucky, Tennessee, Iowa, Missouri, eastern Kansas, and eastern Nebraska.

South Atlantlc and East Gulf: Virginia, North Carojina, South Carolina, Georgia, Florida, and Alabama.

Lower Miasisatppl: Missiasippl, Arkansas, Loulalana, eastern Texaa, and eastern Oklahoma.

Rocky Mountains: Idaho, Montana, Wyoming, Colorado, western South Dakota (Ulack HIIls), New Mexico, Arizona, Utah, and Nevada. Pacific coast: Calfornia, Oregon, and Washington.

That part of the Kaniksu Naticnal Forest in Washington is inciuded in the Rocky Mountain region, while those parts of the Eldorado, Inyo, Mono, and Tahoe Nationai Forests in Nevada are included in the Pacific coast region.

The comparatively small area of rather open woodland, chiefy on farms iying in the Great Plains between the ninety-acventh meridian and the Rocky Mountaina, is not considered in the report. Some $100,000,000$ to $150,000,000$ acres of low-grade woodland and scrub, such as open junlper and pinon of the Weat, scrubby mountain atands, and chaparral, are also omitted. phases of timber supply ouly for parts of States or regious. Some of the timber remaining in the United States has nover been cruised under any method. That cruised has been estlmated by different methods and by dlffelent men, and also at different times when wldely varying standurds of utilization were in effect. For the State of Washington, for example, a large percentage of the estlmates rate back to 1890 and 1895 , when "led fir" and hemlock were considered inferior" species and given little attention.

Posslbly the estimates secured for the southern plne region are as satisfactory as any. Here It was possible to obtain the results of a recent survey which brought together the best estimates available from a large percentage of timber owners. For some regions it was possible to do little more than revise the Bureau of Corporations' estimates by subtracting the cut and depletion as offset by estimated growtb. The Bureau of Corporations' estimates form, in part, the basis for the data used in the southern Mississlppi Valley hardwood region and the Pacific Coast States. In all cases, however, such data were supplemented by additlonal estlmates, wherever obtainable, from such sources as later and more rellable cruises of indlvidual holdings and county tax estlmates.

For hardwood stands in particular the available estimates are not satisfactory. The Bureau of Corporations' study covered only the hardwoods of the soutbern Mississippl Valley, whlch were at that time regarded as having comparatlvely llttle value, and satisfactory estlmates could not be secured. Many of the industries whlch are now dependent for their raw materlals upon the haldwoods are in great need of accurate information as to the extent of existing stands and what they can count on for the future. The data avallable show, however, that the future is very uncertain.

For New Fork results are based on a questionnaile to private owners in 1918 whlch covered the terrltory only in part. Simllar data were avallable for parts of New Eugland. Only a part of the estlmates for National Forest tlmber is based on thoroughgoing cruises.

The report embodies the first attempt to cover for the entire country the total volume of materlal below saw-timber size in cubic feet. It can only be an approximation.

The data on forest areas have been complled from a great variety of sources secured for different purposes by different organizations with varying degrees of accuracy. For several of the classlfications, such as productive and unproductive areas, the data are fragmentary.

The estimates of growth are based on a llmiter number of studies of growth made at rarious times during the past 20 years. While representing somewhat more detalled data than were ever before available, they are stlll very Inadequate and no clalm is made that the figures given are more than an approximation.

In response to the request of the Senate, the Forest Service has endeavored to describe the situation in faily specific terms, using the best information avallable. It recognizes that inuch of the data used lacks scientific accuracy and Is tentative rather than final in character. An attempt has been made to utllize every avallable source of information and to check the figures by the judgment of well-1nformed men in the different reglons.

While an exhaustive and detalled survey of the forest resources of the United States is necessary to establish these figures with finality, there can he no question as to the broad facis of depletion which they indicate.

\section{NEIV ENGLAND.}

THE GROWTH AND DECLINE OF THE LUMBER INDUSTRY.

New England has passed through every stage of forest exploitation from the days when only the best white pines and oaks were merchantable to present dependence upon outside 
lumber and pulp wood. Early cutting was for local consumption, shipbullding, and export. The bomesteads of the first few generatlons were built of the best virgin tImber. Shlpbullding early becane one of the chief industries, for which the whlte pine and oak forests furnished the timber and pltch pine the naval stores. The heavy cutting of early days, particularly for fuel, produced a shortage of wood as early as 1840 in many sections of New Fingland. WIth the Introduction of coal the Industrial centers grew, and the movement to the cities and to the uev lands of the West resulted in wholesale discontinuance of cultivatlon. Much of the second growth timber cut to-day dates from this perlod.

From the Revolution to about 1840 white pine made up almost the entire softwood cut In New England; but soon after that land rose steadlly until it reached a maxlmum of 3,170 million feet in 1907. This period of increased production was due to the introduction of portable sawmils, which made small scattered lots a vallable, to the higher prices of low-grade lumber owing to growing scarcity throughout the country of the better grates, and to the large anount of second growth on deserted farins.

The lumber cut In 1907 was about 7 per cent of the total for the country; in 1918 it had dropped to 1,400 million feet, or about $4 \frac{1}{2}$ per cent, and in actual amount it was less than balf as mucb as in 1907. Particularly marked is the decline in softwoods. Whlle in 1907 the cut of softwood in New England formed 7.6 per cent of all the softwoods cut In the country, in 1918 it had dropped to 4.3 per cent.

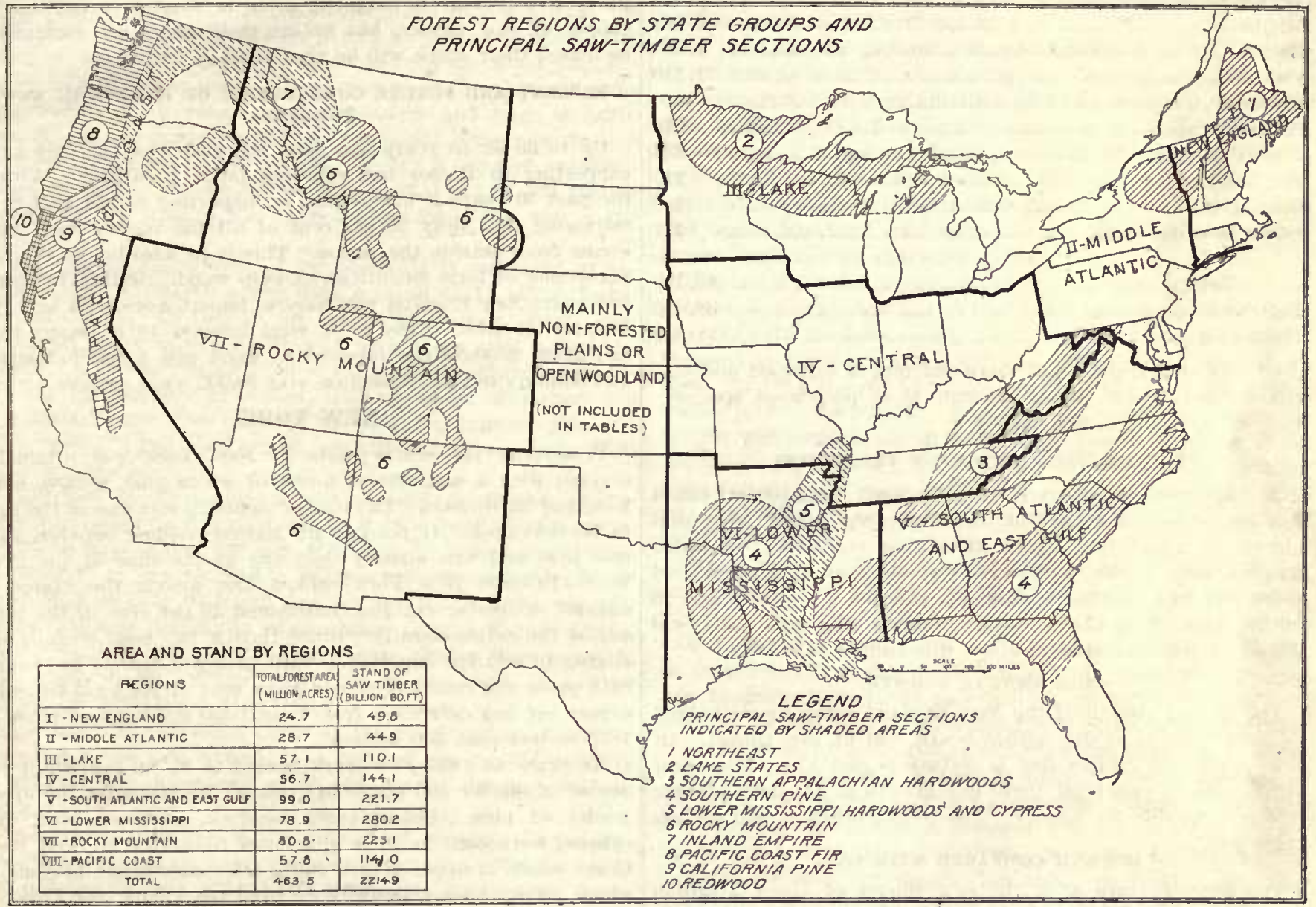

Fia. 1.

spruce operatlons began. By 1870 the original white plne was practically cut except for scattered trees in northern Maine; and by 1880 the second growth pine forests were ylelding an annunl cut of 200 to 300 million boald feet. With the extenslve use of low-grade pine for boxes and matches, this later increased to 600 mlllion feet.

Soon after It became known that wood pulp was a cheap substitute for lags in paper maklng, mllls were bullt in northern New England as well as New York and the chlef development of forest industrles during the past 30 years has been $1 n$ paper manufacture. Spruce alone was nsed at first, but now large quantities of balsam and hemlock are taken. For book paper poplar is used chiefly. Probably four-fifths of the pulp wood still cones from the old-growth folests, but an ever-increasing proportion must come from second-growth stands.

Although the lumber business of southern and central Malne reached its peak about 1850 , the total lumber cut of New Eng-
ORIGINAL AND REMAINING FORESTS.

Area.-Witl the exception of a few small areas, New England in 1620 was a virgln forest, comprising some 39 million acres. In 1920 not more than 5 per cent of this virgin forest remains. The present forest area is nearly 25 mlllion acres. Of thls about 8 per cent, or 2 million acres, is virgin forest, chiefly in Maine, with scattered areas in New Hampslie and Vermont. The last remunant of virgin forest in Connecticut was cut wlthin the past decade. Of the $24,700,000$ acres now classed as forest land 44 per cent, or $10,760,000$, is in saw timber or pulp wood. while 34 per cent, or $8,370,000$ acres, contains nothing but fuel wood, and 22 per cent, or $5,570,000$ acres, is nonproductive. With nearly three-fourths of the saw timber and pulp-wood area in Malne, the poor condition of the remaining New England forests is apparent.

Stand.-The original stand of New England was probably in the neighborhood of 400 blllion board feet, not including 
:anall timber fit only for posts and fuel wood. The present stand of similar malerial is close to 50 billion board feet, or about one-eighth of the original stand. The total stand of wood in New England is estimated to be 21 billion cubic feet $^{3}$ (equivalent to about 70 blllion board feet). Of thls 40 per cent is saw timber or pulp wood and 60 per cent is fit only for fuel. The average stand of all the wooded lands is $10 \frac{1}{2}$ cords per acre. The present stand of saw timber and pulp wood is summarized by species in the following table:

Mililon board feet, lumber scale.

Spruce and fir 23,971

White pine

9,816

Cedar.

Hemlock

Yellow birch

2,789

1,804

Maple

2,933

Beech

2,897

1,635

Oak

Chestnut

Paper birch-

Popiar

Ash.

Pitch plne

Other hardwoods

1,510

Iotal

Softwoods 38,480

Hardwoods 11,319

of this total stand about three-quarters ls softwood and onequarter hardwood, About one-half is of pulp-wood speciesspruce, fir, henlock, and poplar.

\section{THE ANNUAL DRAIN UPON THE FOREST.}

In 1918 there were cut in New England 1,412,100,000 board feet of lumber and $1,446,000$ cords of pulp wood. The total annual cut amounts to about 650 million cubic feet, ${ }^{3}$ of which 65 pel cent is lumber, pulp wood, ties, etc., and 35 per cent fuel wood and fence posts. In addition there is a loss of about 20 million culsic feet, due to disease, insects, and fire. The total anual drain, therefore, is about 670 million cubic feet."

\section{TIE ANNUAL GROWTH.}

The annual growth of the New England forests is estlmated in round figures at 610 million board feet of saw timber. Of this, about 434 million feet is softwoods and 176 million feet lardwoods. In addition, there is a growth of 341 million cublc feet not suitable for lumber. 'The total growth is 475 million cubic feet. ${ }^{5}$

\section{GROWTH COMPARED WITH CUT.}

The annual drain upon the saw timber of about 2 billion board feet is nearly three and one-half times the annual growth of 610 million board feet. The annual drain upon the fuel wood of 235 million cubic. feet is less by 106 millon cubic feet than the growth of 341 million cubic feet a year. It is apparent. therefore, that the growth of low-grade material is somewhat in excess of the actual demunds. In regard to lumber, pulp, and otber high-grade material, however, the situation is anything but encouraging.

\section{THE LIFE OF THE INDUSTRY.}

About. lialf of the entire present stand of saw and puip timber In New Engiand is In commercial tracts; the remalnder is in farm wood lots. It is particularly from the larger com-

2 Throughout the report board feet of lumber are converted to cublc feet of standing timber, and vice versa, on the basis of 219 cubic fcet to 1,000 board feet for saw timber and of 500 cubic feet to 1,000 board feet for cordwood.

${ }^{3}$ Equivalent to about 2,300 million boald feet.

- Equivalent to about 2,375 million board feet.

- Equivalent to about 1,300 million board feet. mercial tracts that the cut of most of the hlgher-grude material comes at present. Few of even the larger timber owners have more than a 20 years' supply. Most of the pulp mills will be cut ont in 20 years. Not over four or five companies own stumpage enougin to last for a longer period. Unless Canadian wood is imported on an increasingly larger scale or effective forestry measures are introdnced innediately, the pulp industry of New England wlll be largely a thing of the past within 30 years. Withln the next 10 years the lumber eut will probably drop to about 1 billion board feet; within 20 year's most of the timber areas contaiuing hlgh-grade lumber will be cut off and the remaining timber will be either on farm wood lots or on a few remaining large tracts and will be made up of second growth or of trees which were left as wortlless at the tlme of the first cutting. The White Mountain National Forest and the State forests may be counted upon to furnish a continuous supply of saw timber, but unless their areas are materially increased their share will be very small.

\section{PRESENT AND FUTURE CONSUMPTION OF LUMBER IN NEW ENGLAND.}

Up to 30 or 40 years ago New England was not only selfsupportlng in timber but exported large quantities. Within the past 30 years it has become an importing region, and it is estimated that fully 30 per cent of all the lumber used now comes from outside the region. This is in addition to the importations of large quantlties of pulp wood. Within the next few years New England will have to import more than half the material it uses. This is of vital interest to a region that has about $\$ 300,000,000$ invested in wood and forest industries and employs in tlis connection over 90,000 wage earners.

\section{NEW YORK.}

Practically the entire State of New Yolk was originally cosered wilb a magnilicent forest of white pine, spruce, hemloek, and hardwoods. The lumber Industry was one of the first to br developed. It reached its highest rolume between 1830 and 1840 and was already declining at the time of the Civil War. In 1850 New York ranked first anoug the States in allount of lumber cut and contributed 20 per cent of the total cut of the entire country. Since then it has been steadily declinlng in relatlve importance until to-day it stands in twentyfifth place and contributes only 1 per ceut of the total cut. Its actuil cut lias decreased fronl over 1,300 million feet prlor to 1850 to less than 350 million.

As early as 1856 New York ceased to be an important exporter of lumber and began to draw on Mlchigan for the upper grades of pine. Pennsylvania hemlock, southern pine, and 'yuress were used' in large quantities from $1 \$ 80$ on, and West Coast wooks in upper grades and special sizes began to cone in albout 1900. To-day Douglas fir from the l'alific northwest is a very considerable factor in the lumber market of the state. The steadily decreasing supply of native woods as comprred with the increase in population is illustrated by the fact that New York's per caplta produetion of lumber had fallen from 300 board feet in 1869 to about 30 board feet in 1918 .

With the gradual settement of the State the area of forest land steadily decreased until to-day it forms about 41 per cent of the total area. The stand of timber is estimated at approxiunately 26 bllion board fert, of which wlite pine, spluce, ancl lewulock comprise about 10 per cent each, and blrch, beech, and maple at totai of 55 per cent. Suruce and liemlock suitable for pulp wood but not lumber comprise some $13,400,000$ cords, whlle material of all species suilable only for fuel and acid wool adds another $107,000,000$ cords. This gives a total stand for the State of apploximately 17,132 million cublc feet.

In quality, the present stand is decidedly inferior to that of enllier days. White pine, of the large size and high quality

- Equivalent to about 49 bllion board feet. 
for which the State was once famous, now furnishes little but the poorer grades. Of the total forest area 62 per cent contains material which is suitable neither for lumber nor pulp and furnishes only fuel or acid wood. While the area of lands completely denuded is comparatively small, the original forests are being followed by stands of decldedly inferior quality, both as to species and grades. The damage by fire is being steadily redncel by systematlc fire protection, but the methods of cutting in private lands are such that an increasingly large area is left partially or wholly devastated.

\section{PENNSYLVANIA.}

The forest history of Penusylvania has been similar to that of New York. Once practically covered with a heavy timber stand, Pennsylvanla for many yefurs exported large quantities of lumlier. In $1 S 60$ It stood first among the States in lumber productlon. As eqrly as 1870, however, the stand of white pine, the most valuable species in the State and formerly one of its principal export woods, had diminished to such an extent that Imports from Michigan began. The depletion of the white pine was followed by an increasing cut of hemlock and later of hardwoods, and the State reached its maximum lumber production of 2,440 million board feet in 1889. To-day it occupies twentietl place in lumber production, and its aunual cut of 530 million board feet constitutes less than 2 per cent of the cut of the country.

The present forest area of Pennsylvanla is estimated at approximately $12,000,000$ acres, with a stand of 11 billion board feet of timber. Of this 70 per cent is hardwoods, chiefly oak, chestnnt, and northern hardwoods, and 30 per cent softwoods, one-half henlock. In addition to the stand of material suitable for the nunufacture of Inmber, it is estinated that there are $380,000,000$ cubir, feet of wood suitable for railroad tles and mlne props. The totai stand, including fuel wood, is 5,200 inllion cublc feet.

Depletion in Pennsylvania has already progressed so far that the complete cessation of large-scale logging operations, of wilich only a few are now left, may be anticipated within a decade. It has reached a point where the annual lumber production is only 60 board feet per caplta, or about one-fifth of the average per capita consumption for the United States. The Pittsburgh district alone uses nore lumber than is cut in the whole State. Wllliamsport, which once had an annun output of $300,000,000$ board feet of lumber, now has not a single sawmill. In those parts of the State where the forest constituted the sole resburce the trail of the lumber industry is marked by abandoned mills and practicaliy deserted villages.

The steady decrease in the amount of standing timber has been accompanied by a deterioratlon in quality. Vlrgin stands are practlcally gone, old-growth white pine, for example, belng reduced to some 10,000 acres, practically all in a single tract which will be cut out in the nert five years. Only about 50 per cent of the total volume of wood now standing is sultable for manufacture either as lumber, pulp wood, ties, or props. The average area burned orer annually is 500,000 acres, and much of this has been burned over again and again. In addithon to the damage from reckless cutting and fires the State has suffered severely from the chestnut bark dlsease. Nearly one-seventh of the entire State, once richly wooded, is said to be practically barren. Several counties that were once rich in forest and prosperous are now almost bankrupt because the timber is gone.

\section{THE LAKE STATES.}

GROWTH AND DECLINE OF THE LUMBER INDUSTRY.

White pine.-The history of lumbering in the Lake States during the greater part of the past century is substantlally the history of white-plne exploitation. Lumbering began in Michl-

Equivalent to about 16,600 million board feer. gan and Wlsconsin about 1835. Pine in enormous quantities drew lumbermen from the Last, and before 1870 these States captured the lead in lumber productlon. They held it until superseded by the southern plne reglon, between 1900 and 1910 . The peak of production was passed In 1892, when the reported ontput was a little more than $8,900,000,000$ board feet-largely white pine. This was an Increase of 123 per cent over the cut of 187\%. In 1899 Wisconsin, Mlchigan, and Minnesota, In the order named, were still the leading three States, with a total production of $8,700,000,000$ feet, two-thirds pine; but in 1918 they had fallen to elghth, thliteenth, and eleventh, respectively, and their total output had fallen to $3,220,000,000$ board feet, of which only 35 per cent was white pine-mostly from Minnesota. Wisconsin now produces less than the second-growth cut of either Maine or New Hampshire, and Michigan, from leading the country from 1870 to 1895 , now actually cuts less than half as much as Massachusetts.

As the Lake States forests dwindled, wblte-pine lumber went down, both in quantity and quality, and Norway and jack pines and even tamarack were admitted as lower grades of "northern pine lumber." The fine quality timber whlch gave white pine Its reputation is now nearly all gone. In Minnesota two-thirds or more of the cut is box lumber. Only small, scattered remnants of the old-growth whlte-pine forests remaln in Wisconsin and upper Michigan, and in lower Mlchigan the nost wldely known tract covers about 100 acres.

Hemlock.-As the higher grades of pine grew scarce and expensive, hemiock, once left in the woods as worthless, began to compete with the successively lower grades of pine introduced. Hemlock production reached its peak-1,600,000,000 feet-about 1906. In 1914 the cut had fallen to little more than a billion, and in 1918 to $800,000,000$. This does not, however, lnclude the cut for pulp, which would Increase the total volume by about one-third. By affording a market for cordwood, pulp manufacture is taking the small bemlock timber along with the large and thus delaylng or preventing the renewal of the supply of large tlmber.

The northerm hardwoods.-Maple, birch, beech, basswood, and elm form at least 85 per cent of the total stand of hardwoods and furnish over 92 per cent of the total bardwood cut in the Lake States. As with hemlock, the logging of hardwoods began as an aftermath of the white-plne logglng. Hardwood production progressed gradually from culling operations taking only the best trees of the preferred species to cuttings such as those made at present for chemical distillation and charcoal, in which even tops, limbs, and saplings are utilized. Beech was one of the latest species to come into commercial demand; less than two decades ago it was a common practlce to leave all the beech, which fires later destroyed. Now, the hardwood-uslng industries absorb not merely the upper grades but anything which wlll make lumber, and in some cases even cordwood.

The veneer industry makes a constant demand for bighgrade logs. Such logs supply also the bulk of the npper grades of lumber. There has been a constantly growing demand for both veneer and bigh-grade hardwood lumber, expressed in the pronounced growth of such industries as the musical instrument and toy trades. For a considerable part of this demand lower grades ought to be acceptable; but so long as the demand for upper grades exists manufacturers will attempt to fll it, and the stand will dwindle the more rapidly.

\section{ORIGINAL AND REMAINING STAND AND RATE OF CUT.}

The original forests occupied practically all the land area of Mlchlgan, Wisconsin, and the part of Minnesota not natural prairle-a total forested area of approximately 112 million acres. Lumbering and the clearing of land for cultivation have reduced the merchantable forest corer to little, if any, more than $24,000,000$ acres, about 58 per cent In farm woodlots of relatively smali timber, commonly second growth, and 42 per cent in com- 
mercial timber tracts, in many cases already culled of their choicest trees. A very large part of the once heavily timbered land, about $20,000,000$ acres, is now fire-swept and devastated sand plain and swamp, much of it with little or no promise of reproduction.

The original white pine stand of the Lake States has been estimated by Dr. B. E. Fernow at not less than $350,000,000,000$ board feet. After less than a century of lumbering, fire, and settlement, only about $8,000,000,000$ feet of white and Norway pine remain, largely in Mimnesota. In 1918 the reported cut of white pine In the Lake States exceeded a billion feet. Another decade will see the practical exhaustion of their commercial supplies of white pine.

Lower Peninsula of Michigan.-The depletion of commercial timber has proceeded furthest in the Lower Peninsula of Michlgan, where less than a million (probably not much over half a million) acres of hardwoods and hemlock remain. The hundreds of large sawmlls that once operated had fallen off in 1918 to about 45 that cut more than $1,000,000$ board feet apiece. The number is rapidly becoming smaller, and within five years there wlll hardly be a half dozen large mills left. The exhaustion of the remaining old-growth stands will mark the end, among other valuable specles, of the highly prized "Lower Michigan hard maple," long reputed to be the best in the Lake States. From then on whatever lumber is cut wlll cone mainly from farm woodlots, in small amounts and sizes, and of poorer grade.

Wisconsin and the Upper Peninsula of Michigan.-In the adjacent forest areas of WIsconsin and the Upper Peninsula of Michigan the case is better. In 1908 the Bureau of Corporations estiniated the timberland at about $10,329,000$ acres, with a stand of 65 billion feet. During the last 12 years probably 30 billion board feet in lumber has been removed. This would leave only 35 billion, enough at the present rate of cutting to last 15 years. There can be no doubt, however, that there is much more timber than this. The 1908 estimates were too conservative. There is reason to believe that the timberland still amounts to 4 million acres in upper Michlgan and 2 million in Wisconsin, and that the total merchantable stand is at least 48 billion feet. This would insure a continued supply, at the present rate of cut, for about 20 years. This rate will not, of course, continue, but will decrease as successive mills saw out. The rate of cut is considerably heavier in Wisconsin than in the Upper Peninsula. The larger number of Wisconsln mills and the considerably smaller stand of timber indicate a much quicker falling off in the cut and an earlier termination of the supply there than in upper Michigan.

In Wisconsln, assuming a diminishing rate of depletion, the annual lumber cut will be likely to fall off within 10 sears to 75 pér cent, in 15 years to 40 per cent, and in 20 years to 16 per cent of the present cut, and in 25 years the timber will be practically gone. Cutting for other purposes than lumber will add appreciably to the amount of timber taken out. Furthernore the pressure of an increasing demand, by stimulating the rate of cut both at the blg mills and at numerous smaller mills, which will probably operate, as at present, in small patches of timber, will very likely hasten the final exhaustion of the timber. All things considered, It is doubtful if there will be any appreclable anount of timber left in comnercial lollings in Wisconsin at the end of 20 years. Growth does not enter into the computation at all, unless a radleal change is made in the direction of efficient fire protection and the application of forestry.

In upper Michigan the stand will last conslderably longer. Herc 60 per cent as many mills operate In twice the timberenough, in fact, to last 40 years at the present rate of cutting for lumber only. Some new operations are already contem- plated, however, and the cut for lumber and other products will doubtless increase within the next few years. One princlpal holder is reported to have estimated the life of the stand at 25 or 30 years.

Minnesota.-Timber conditions in Minnesota differ widely from those in Wisconsin and Michigan. The Wisconsin lumber cut for 1918 was 85 per cent hardwoods and hemlock, while that of Minnesota was 91 per cent white pine (which includes also a considerable amount of Norway pine and other species in the lower grades). Less than 5 per cent of the reported cut was of hardwoods.

The timbered area of Minnesota was estimated by the Bureau of Corporations in 1908 at about $5,651,000$ acres, and the stand at $23,200,000,000$ board feet, 81 per cent of which was softwoods. A recent estimate by the Minnesota State forester places the softwood stand at 11,450,000,000 board feet, of which 41 per cent is white and Norway pine, 17.5 per cent jack pine, 24 per cent spruce, balsain, and cedar, and 17.5 per cent tamarack. The tamarack, whlch has been the greatest hewed-tie resource of the region, has practically all been killed by the larch sawfly, and must be salvaged soon if at all.

The pine forests of Minnesota have been thoroughly culled of their best material, and production now runs heavily to box lumber.

The number of mills operating in this region is being reduced rapidly. Within the last three or four years at least four of the large mills have burned, and these will prohably not be replaced. Five have recently cut out, and two have only a year's supply. This means a decrease of 30 per cent in the total cut of the State and of 33 per cent in the cut of the big pine mills. The annual cut of the remaining mlls will aggregate at least $600,000,000$ feet. These mills depend for the great bulk of their cut upon white and Norway plne, the remaining supplles of which are estimated by the Minnesota State forester at $4,700,000,000$ board fect. Thls will not last much more than seven years at the present rate of cutting. If the estimate of supply is increased by one-tbird, the perlod of operation would be 10 years at the present rate. As the mills exhaust their supplies, however, the rate of cuttlng will dimlnish.

Condition of the remaining supplics.-The stands considered above are those which are belng or could be logged on a large scale to large mills-mills of $\mathbf{1 0}$ million board feet or more annual capacity. Such mills now supply about 90 per cent of the lumber produced in the Lake States. Their holdings, even though culled, are almost wholly, of old-growth timber of superior quality as compared with second growth.

These concentrated commercial stands, aggregating about 63 billion board feet, contain about 57 per cent of the total stand of timber in the Lake States, which amounts to probably 110 billion board feet. Of this total about 30 per cent ( $33 \frac{1}{3}$ billion feet) is widely scattered in farm wood lots, while 13 per cent (about 141 billon feet) is In the swamps, jack pine and scrub hardwood plalns, aspen and blrch stands, and cut-over lands in the North. The timber in these stands is far helow that of the commerclal stands in quality. The greater part is second growth. It is smaller, more limby, and much of it has been badly damaged by fire. Furthermore, it is largely in small, scattered tracts unsuited for efficlent largescale operations. In addition, about 19 million acres bear a cordwood stand of about 113 million cords below saiv-timber size. If the lumber stand also is reduced to cords, the total stand in the Lake States is 630 million cords, or 50,584 milllou cublc feet.

\section{THE ANNUAL DRAIN UPON THE FOREST.}

Inmucr cut comparcd with total cut.-The normal lumber cut of about $3 \frac{1}{2}$ billion board feet forms less than half of the total volume of wood cut annually In the Lake States for all purposes. The lumber cut is the equivalent of about $\mathbf{7 7 0}$ 
million cubic feet of standing timber. The total output of wood in all forms is close to 1,600 million cubic feet. The classes of output not corered in the immber-cut statistics in clude pulp wood, fuel, and distillate wood, hewed ties, posts and poles, and logs and bolts used for veneer and other purposes. Of these, pulp wood and distillate wood make up probably 130 million and fuel wood 600 million cubic feet. The rewaining 100 inillion cubic feet consists of veneer, cooperage, excelsior stock, ties, posts, poles, and other products.

Deterioration of the forest.-In addition to the cut there is a constant loss to standing timber from tire, wind, insects, disease, etc., probably amounting to an annual average of from one-fourth to one-half of 1 per cent of the stand. This is equal to one-half billion board feet, or $110,000,000$ cuble feet, of standing timber. It thcludes such losses as that of tamarack, of which, as previously shown, about 2 billion board feet has been killed by the sawfly in Minnesota alone. There is also considerable loss from decay following injuries, such as frost cracks and ice breakage. In most of the commercial stands daniage from these sources is not made up by growth, since these forests are generally much beyond the age of actire growth.

\section{THE ANNUAL GROWTII.}

Gronoth compared with eut.-The estimated annual growth in the Iake States is much less than the cut.

\begin{tabular}{|c|c|c|c|}
\hline$x^{2}$ & $\begin{array}{l}\text { Estimated } \\
\text { anmual cut. }\end{array}$ & $\begin{array}{c}\text { Estlmated } \\
\text { annual } \\
\text { growth. }\end{array}$ & $\begin{array}{l}\text { Grewth } \\
\text { in per } \\
\text { cent of } \\
\text { cut. }\end{array}$ \\
\hline 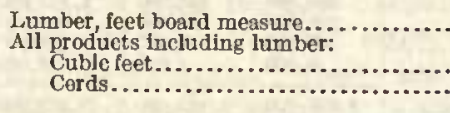 & $\begin{array}{r}3,500,000,000 \\
11,600,000,000 \\
20,000,000\end{array}$ & $\begin{array}{r}988,000,000 \\
1468,000,000 \\
5,850,000\end{array}$ & $\begin{array}{l}28 \\
29\end{array}$ \\
\hline
\end{tabular}

I In terms of lumber, the aggregate annual cut of all products would be about $5,160,000,000$ board feet, and the annual growth about $1,490,000,000$ board feet

These figures indicate that the total rate of cuttlng is more tiran three times the total rate of growth, and that the stand suitable for Jumber is being cut more tinan three times as rapidly as it is growing. Furthermore, the larger part of the cut is from old-growth stands in the North, while nearly all the growth is in widely scattered second-growth stands. The cut is-relatively concentrated, while the growth is widely distributed and without reference to the commercinl advantages of location. This is a-consideration of great significance for the future of the wood-using industries. The concentrated supplies are steadily waning. Their disappearance will mean the death of industries unable to adant their production to a supply limited by the rate of growth or to import.

Fire renders millions of acres of cut-over forest land in the Lake States unproductive. If fires could be kept out, the growth on these repeatedly burned lands would probably eventually increase 50 per cent, and could be increased still further hy intensive management.

The life of the industry.-At a diminishing rate of depletion due to the cutting out of one holding after another, it is estlmated tiat the lumber cut of the Lake States at the end of the next 5 and 10 years will be about as follows:

Estlmated cut, 1925 $2,400,000,000$ Present annual cut $3,500,000,000$ Estimated cut, 1930

$1,800,000,000$

This represents only the production from commercial tracts. As the coinmerclas stands dwindle the production of Jumber and other products from farm wood lots and from second growth in swamps and cut-over areas may be expected to increase consirlerably in proportion to the total cut, though not in actual amuunt. Such lumber will be much Inferior in quality to that from the commercial stands.

\section{PRESENT AND FUTURE CONSUMPTION OF LUMBER IN THE} LAKE STATES.

The average annual per capita consumption of lumber in the Lake States is probably not far from the average for the whole country-300 board feet. Assuming a 12 per cent increase in population since 1910 (the increase for the previous decade was at the rate of 14.06 per cent), the present population of the Lake States is about $8,000,000$. The total annual consumption of lumber in the three States is thus about $2,426,000,000$ board feet, or 70 per cent of the lumber produced.

Comparison with the estimates of future cut above given Indicates that by 1925 the local consumption will be equal to the local production, assuming no increase in population and the same per capita rate of consumption. At the end of a decade, allowing for a 10 per cent increase in population, consumption will exceed cut by nearly 50 per cent. In other words, the per capita consumptlon must either fall from 300 to nearly 200 board feet per year or the Lake States must import nearly one-third of the lumber needed for home use. With each succeeding year the discrepancy between consumption and local supply will become greater. Much western fir and pine lumber is already being consumed in the Lake States, and as the local cut decreases they wlll depend more and more upon the far West. While an actual lumber shortage may not, therefore, be antleipated as long as the western stands hold out, the lack of a local supply will be felt in increased prlces.

\section{THE SOUTHERN YELLOW-PINE REGION.}

\section{THE GROWTH AND DECLINE OF THE YELLOW-PINE INDUSTRY.}

The pine forests of the Southeastern United States, beginning along the Atlantic coast, have been exploited for naval stores and other forest products from the time of the first settlements. No extensive derelopment of the lumber industry,. how'ever, took place until the seventies of the last century. Before the Civil War a limited amount of southern pine lumber was shipped to Baltimore and Philadelphia in schoon. ers by sawmills on the eastern shore of Maryland and near tidewater in Virginia. After the Civil War the industry spread to Georgia, Mississippl, and the other Gulf States. The markets north of the Ohlo River made their first demands for southern pine about 1875. By that time the Northeastern States had lost their leadership in lumber production, and the Lake States were coming to the front with about 35 per cent of the country's cut. The great development of the southern pine inclustry began in the early nineties. About 1892 yellow pine from the Gulf States and Arkansas began to crowd white pine in the markets north of the Ohio River. Vast quantitles were used in the construction of the World's Fair buildings in Chicago. An extensive demand was created by the low prlces in the earjy nineties. This demand spread into the Lake States, the Prairie States, and the Eastern States. At the end of the nineties southern yellow pine was leading the country in the cut of softwoods. In 1909 its productlon reached the peak, with nearly half of the entire country's cut of softwoods, and from then on began to decline.

Southern yellow pine is still the most important single factor in the lumber production of the United States, furnishing about 41 per cent of the cut of softwood lumber and 35 per cent of the entire lumber cut. It will remain an important factor for at least the next 10 or 15 jears. Within the next 8 or 10 years, however, it is certain to undergo profound changes.

\section{THE ORIGINAL AND THE PRESENT PINE FORESTS OF THE SOUTH.}

The original pine forests of the South Atlantic and Gulf States covered from 125 to 130 mlllion acres and had a stand of timber close to 650 billion feet. Of this about two-thirds was longleaf plne and one-third shortleaf pine.

8 Under "longleaf pine" are ineluded longleaf and slash plnes; under "shortleaf plne" are included sbortleat, loblolly, scrub, and other sbort-needled pines. 
To-day the area of virgin yellow-pine forests is about $23 \frac{1}{2}$ million acres, or a little less than one-fifth of the original acreage. (See Table 1.) The stand of virgin timber is about 139 billion board feet, or a little over one-fifth of the orlginal stand.

TABLE 1.-Southern yellow-pinc region-Classification of pine land by character of growoth.

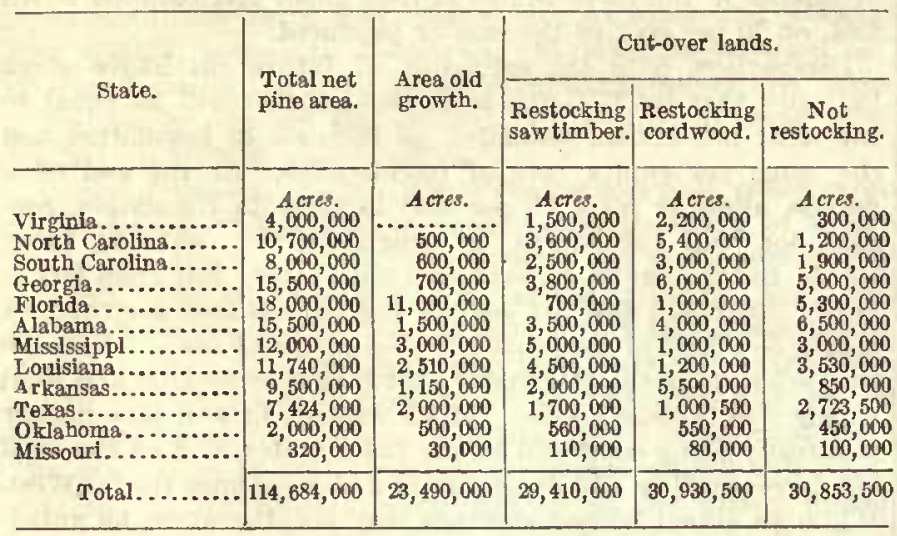

Four-fiftlis of the original yellow-pine forests has been cut since 1870.

Out of the more thau 100 million acres of yellow-pine land that has been eut over about 29 million acres now supports second growth of merchantable sizes and nearly 31 millon acres cut over recently second growth not merchantable. About 31 million acres of cut-over land has not come back to plne. althougl much of it is more suitable for timber growth than for agriculture. As the nonrestocking areas do not produce any uew growth and growth in virgin timber is offset by deterioration, the total area on whlch yellow pine is now growing is about 60 million acres.

The largest areas of old timber are chiefly in the Gulf StatesTexas, Louisiana, Mississippl, Alabama, and Florlda. Areas of second growth are most extensive in the older South Atlantic States-Virginia, North Carolina, South Carolina, and Georgla.

Total merchantable stand.-The total stand of merchantable Jellow pine, both virgin and second growth, has recently been estimated at about 258 billion feet, of which 139 billion, or 54 per cent, is old timber, and 119 billion feet, or 46 per cent, is second growth.

By States the merchantable pine stand is distributed as follows:

\begin{tabular}{|c|c|c|c|}
\hline Louisiana & $\begin{array}{c}\text { M feet. } \\
47,348,400\end{array}$ & North Carolina & $\begin{array}{l}\text { M leet. } \\
\text { 15 } 300.800\end{array}$ \\
\hline Mississippi_ & $40,476,200$ & Virginia & $8,698,000$ \\
\hline Florlda & $36,429,300$ & Oklahoma & $4,791,400$ \\
\hline Texas & $27,524,700$ & Missourl_ & 364,700 \\
\hline Alabama_. & $25,316,400$ & & \\
\hline Georgia__- & $21,807,600$ & \multirow{3}{*}{$\begin{array}{l}\text { Total (lum- } \\
\text { ber scale) }\end{array}$} & \\
\hline Arkansas___._. & $15,743,700$ & & $7,691,000$ \\
\hline South Carolina & $13,889,800$ & & \\
\hline
\end{tabular}

The present stand is about equally divided between longleaf and shortleaf pine, with probably a slight preponderance of shortleaf pine over longleaf, the shortleaf pine being more abundant in the South Atlantic States and the longleaf in the Gulf States.

\section{ANNUAL DRAIN UPON THE FORESTS.}

The cut of yellow-pine lumber in 1918-an abnormally low year-was in the nelghborhood of 10 billion feet. Lumbermen estimate a cut for 1919 in excess of 15 blllon feet. The average cut for the five-year period before the war, 1911-1915, was about $14 \frac{1}{2}$ billion feet, to which must be added at least $1 \frac{1}{2}$ blllion feet of hewn tles, poles, and posts, in all a cut of about
16 bllion feet of saw timber. There is also being cut in the pine area of the Sonth about $12,250,000$ cords of fuel wood.

In addition to the cut there is every year a considerable loss of mature saw timber due to windfall, turpentining, Insects, fires, and diseases. This loss may be conservatively placed at from one-fourth to one-half of 1 per cent of the entire merchantable stand, or at present from $650,000,000$ to $1,300,000,000$ board feet per year. In all, the annual drain upon the forests is nearly $4 \frac{1}{2}$ billion cubic feet of wood.

\section{THE ANNUAL GROWTH.}

The annual growth is estimated at about 3 billon feet board measure on the merchantable second-growth areas and 1 billion cubic feet ${ }^{\circ}$ on the area of unmerchantable second growth, or in all in the neighborhood of 1,660 million cubic feet ${ }^{10}$ a year, or nearly 30 cublc feet per acre for the entire growing area. (See Table 2.)

TABLE 2.-Southern yellow-pine region-Annual grouth of saw timber and cordwood by States.

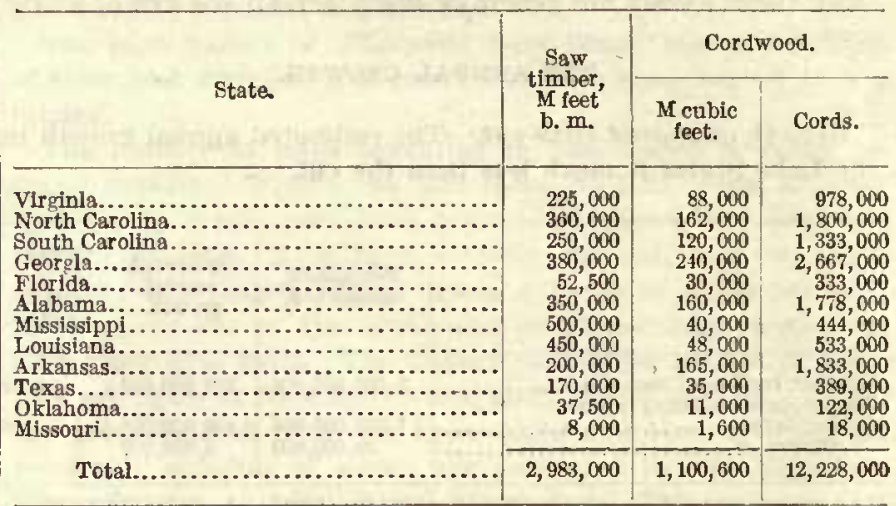

CUT AND GROWTH CONTRASTED.

The amount of yellow pine that is cut is thus about three tlmes the annual growth. In saw timber the disparity is even greater. The annual growth upon the areas of merchantable timber is in the neighborhood of 3 billion feet, whlle the cut of saw timber is 16 billion fect. In other words, the present cut of saw timber is more than five times the present annual production.

If the present merchantable second growth were not cut into for the next 10 or 15 years, but were allowed to grow at its present rate, and the unmerchantable second growth were allowed to reach merchantable size without being prematurely turpentined, the annual growth of saw timber would be considerably increased. ThIs merchantable second growth, however, is now also being cut and its area decreased at a rate of not less than $1 \frac{1}{4}$ million acres a year. About a quarter of the present yellow pine cut comes from second growth. Within the next 20 or 25 years the entlre area of the present merchantable second growth may be completely cut over, and large areas will not come back to pine unless there is a decided change in the present procedure in regard to protecting the cut-over land from fire and hogs.

\section{DETERIORATTON OF THE FOREST.}

It is doubtful If the South will ever agaln grow timber to the sizes which we find in the virgin stands. The second growth now cut for saw timber is inferlor in quality to the old stands. While trees in the virgin longleaf-pine stands yield on an average from three to four logs which run six or seven logs to a thousand feet, trees in the second-growth stands

- Equivalent to about 2 bllllon board feet.

10 Equivalent to about 5 blllion board feet. 
average at most two or two and a lialf logs per tree, and the logs run fifteen to the thousand. The amount of upper grades that is sawed from second growth is much smaller than from virgin tlmber. For Instanee, a mlll tally on a certaln operation showed that virgin timber sawed out on the average about 55 per cent of the ligh grades, whlle second growth barely ylelded 19 per cent. An inferior forest is therefore succeeding the vlrgin timber and the higliest grades are not being replaced at all.

Change to inferior species.-Deterloration is taklng place not only in grades but also in species. The most valuable timber trees of the southern pines are longleaf and slash pines, both for their timber qualities and as a source of naval stores. The longleaf pine, particularly throughout the Gulf States, as a rule does not come in on cut-over land, because of sparse seed production and the grazing of hogs. Unless cut-over longleaf-pine land is protected by hog-proof fences or by stock laws the areas of longleaf pine will be greatly dimlnlshed. The original proportion of longleaf in the southern plne forests has already been redueed for the remainlng mercliantable timber from twothirds to a little less than half. Nortl Carolina, which once liad large areas of longleaf pine and was famous as the "Longleaf Pine State," can boast now of hardly 50,000 acres of second-growth longleaf pine widely scattered in small areas. A large part of the remaining vlrgln longleaf area will, after logging, elther become nonproductive or be restocked to a considerable extent with shortleaf pine.

\section{THE LESSON OF THE SOUTH ATLANTIC STATES.}

Iarge areas of second growth now found in the older South Atlantic States and a fairly permanent cut of timber by sinall milus are often taken to indicate what the future of the Gulf States ls to be after the larger sawmills have completed their logging operations. There are vital differences, however, In the handling of the tlmber in the two regions. The virgin forests in the South Atlantic States were cut over very lightlyoften for local consumption only-and the logging was done by animals. This left many young trees which soon formed a new merchantable stand and provided ample seed for young growth. The present-day steam logging in the Gulf States amounts to clear cutting over large areas, and even Inferior trees are frequently brought to the mill.

The virgin forests of the South Atlantlc States contalned less longleaf plne than the Gulf States. In Virginla, for Instance, there was practically none. In the Gulf States longleaf forms the bulk of the stand, and it is the longleaf reproduction whlch ls most affected by the free ranging of hogs. Furthermore, the turpentine operators are now tapplng more and more young trees, and by excessive turpentining prevent many from reaching maturity.

It Is certaln, therefore, that under present practice the Gulf States will not have as much second growth after the virgin forests are cut out as the older South Atlantle States now have.

\section{LIFE OF THE YELLOW PINE INDUSTRY.}

A recent survey covering 5,400 mills, owning or controlling practlcally the entire remaining virgin stand in the South, Indicates that 4,419 mills, or nearly 82 per cent of all those reported, will cut out in 5 years or less, and the output of vlrgiu tlmber will be reduced by nearly 50 per cent; that 5,254 mills, or over 97 per cent, will cut out their timber in 10 years or less, with a corresponding reduction in the output of 78 per cent; that in 20 years all the mills, except 12 , will have cut ont thelr timber, and their production will have been reduced to only 3 per cent of the present output. This does not mean, however, that the total lumber production will be reduced at thls rate. As the larger sawmills cut out small mills will take their place and will work in the second growth and on the small scattered tracts which under present conditions can not be economically logged in large-scale operations.
Although In five years over 19 per cent of the present virgin timber will be cut out, only about 11 per cent of the entire merchantable stand will be used up. In 10 years 52 per cent of the entire vlrgin tlmber wlll be gone, but only 30 per cent of the entire present merchantable timber. In 20 years nearly 90 per cent of all the virgin timber will be exhausted and over 50 per cent of the entlre merchantable timber. As the virgin timber dwindles, the second growth will contrlbute more and more to the production of yellow-plne lumber. In 10 or 12 years second growth wlll probably contribute two-tlilrds of the entire cut.

Although the exlutustion of the virgin timber does not mean entire exhaustion of the yellow-pine industry in the South, the life of the industry as now constituted is largely the life of the present large sawmllls. When the larger mills cut out at the present locations, they will cease to figure in the industry; for it is now almost impossible for an operation of any magnitude to secure a location which commands enough timber to justlfy logglng operations. The South wlll undoubtedly continue, as New England, to be a lumber-produclng region. It wlll cease, however, to be a national factor; and from a general utillty wood, the hlgh-grade yellow pine, as the white pine, will become a specialty wood, wlille the sccond growth wlll furnlsh inferior grades for industrial purposes and for local use. In about 10 years the yellow-pine region promises to take second place as a national lumber-producing center.

\section{REDUCTION OF THE OUTPUT.}

Iunber production of yellow plne in 1930, allowing for new sawmills to take the place of the larger sawmills which will be cut out, it is estimated will be about $9 \frac{1}{4}$ billion feet, a reduction of nearly 6 billion feet, or 38 per cent, from the estimated productlon of 1919 . This means a yearly decrease in the output of about 550 million feet, or a little over $3 \frac{1}{2}$ per cent. If, however, to the sawed lumber ls added the yearly cut of saw$\log$ material for hewn ties, poles, and posts, and the loss of merchantable timber from windfall, turpentining, fires, insects, and diseases, the reduction is likely to be at the average rate of 700 million feet, instead of 550 million feet. This does not mean that every year the output will be actually diminlshed by 700 million feet. If the present high prices for yellow-pine lumber contlnue, production may be stimulated and the output may hold up during the next few years Instead of declining. Should, howerer, such an increased production take place, the decline in the output will be so much the more rapld toward the end of the llfe of the industry.

\section{PRESENT AND FUTURE CONSUMPTION OF LUMBER IN THE} SOUTH.

The Southern States consume locally about one-third of their total pine cut, or 5 billion feet. By some good authoritles home consumption is placed even at 50 per cent.

The South has passed the threshold of a great agricultural and industrial development. At the same time the South is underbuilt. The average value of its bulldings per farm is less than in any other section of the country. With agricultural and industrial development the standards of rural and urban life will become higher; and better and larger houses will he built. This will require more lumber.

The annual consumption of lumber is expected therefore to increase until in 10 to 12 years it may amount to 9 billon feet. By that time the output of yellow plne will probably slırink to 9 bllion feet. Thus by 1930 the South may cease to be an exporting region, and may produce barely ellough lumber for its own needs. This does not mean that no southern yellow-pine lumber.will be shipped out of the Southern States, but it does mean that the exports and imports of lumber will balance. After 1931 the South wlll become more and more an importing region. In 15 years the South will become dependent for its own needs upon large Importations of lumber from the Paclic coast. 


\section{CYPRESS REGIONS.}

Cypress has probably passed its maximum production, and but a short time remains during whlch it can occupy a place of importance in the lumber Industry.

The value of cypress for house building and fencing was early recognlzed by settlers in the South. Under the colonial rule of the Spanish and French traflic in shingles and cypress lumber with the West Indies was of great Importance. Great quantlties were used for the hogsheads and barrels of the sugar and molasses trade. After the opening of the southern pine forests the general use of cypress as the principal material for house construction, except for shingles, fell off, and the recent demands from distant markets date from the falling off of the white pine supply of the North.

Until recent years only the largest and best trees nearest to streams and shallow canals in whlch they could be floated were cut. Utilizatlon was therefore very incomplete. With the introduction of the pull boat in the ninetles and finally the expenslre steam skidder systems, and a better understanding of the value of the wood, no stauds remalned inaccessible.

The cypress cut reached 495 million board feet In 1900 ; by 1909 it was 955 million; and in 1913 it exceeded 1 billion feet. It has fallen off since, with a reported cut in 1918 of only 578 million. Lumbering is followed by practically no second growth, so that with the completion of present operations the cypress industry ends.

In 1909 the Bureau of Corporations estimated the total stand of cypress at 40 blllon feet. The best available figures to-day place the total at 22,921 mlllion feet, and the totals for Louisiana and Florlda, which furnish the bulk of the cut, at approximately 11,000 million. If the annual cut during the next few years be placed at approximately 700 million feet, with the additional large and unknown amount used annually in the rough for plling, poles, and the llke, it is evident that without growth in the remaining stands and on cut-over lands the supply in sight in the present producing centers, Louislana and Florida, can not last more than 15 years. A largely diminished yearly production will be experienced much sooner. Well-informed lumbermen place the duration of the tmportant commerclal cut at no longer than 10 years.

\section{THE ROCKY MOUNTAIN REGION.}

The Rocky Mountain reglon includes Moutana, Idaho, IVyoming, Colorado, Utah, Nevada, Arizona, New Mexlco, and western South Dakota. ${ }^{11}$ It is a region with wide differences in character and denslty of timber growth, in production and consumption of lumber, and in the probable future development and life of the lumber Industry. Thus western Montana and Idaho, hecause of the heavy stands of white pine, larch, and yellow pine, might properly be considered part of the Pacific coast region; whlle Utah and Nevada, wlth their open forests, have cutirely different economic problems to meet as far as the timber supply is concerned. Simllarly, Arizona and New Nexico are practlcally an economic unit by themselves; Colorado and Wyoming form anotler economic unit, and Soutls Dakota still another. Tlerefore in considering the present tluber siluation and the future ontlook for the mountain region as a whole, the different sections of the reglon should be kept in inlnd.

\section{DEVELOPMENT OF THE LUMRER INDUSTRY.}

The development of the lumber industry began in the early fifties, chiefly to supply the mines. Even now mining is the heaviest consumer of wood in several sections. After 1900 the

${ }^{11}$ That part of the Kaniksu National Forest in Washington is included in the Rocky Mountain region, while those parts of the Iidorado, Inyo, Mono, and Tahoc National Forests in Nevada are included in the racific coast region. lumber industry assumed more than a local character and began to ship lumber to the Mississippi Valley and eastern markets. The region is still sliort of the development whlch it will reach in lumber manufacture. It has slown a steady increase for the last 20 years, and the present cut amounts to about 5 per cent of the entire production of lumber in the country.

Wester'n Montana and Idaho, because of the heavy stand of westeru white pine, larch, cedar, and yellow pine, is the most important section from the standpoint of timber supplies. Within these two States is 75 per cent of the entre stand of the highly prized western white plne. Wyoming, with its dense and extensive stands of lodgepole pine, is an important source of material for rallioad tles. Colorado, more than half of whose timber is Engelmann spruce and which has also extensive lodgepole pine stands, is an important tie and lumber-producing center for the central Rockies. Western South Dakota, with its valuable yellow pine stands, is the center of lumber production for the State and the adjoining treeless region. Northern Arizona and New Mexico, with large open yellow plne forests, supply much of the lumber used in the Southwest and ship some to the North and East.

\section{ORIGINAL AND PRESENT STAND.}

The original forest area of about 64 million acres has now been reduced by about 3 million acres. Thls reduction is chlefly in Mrontana and Idaho, where much of the early logging was on agricultural lands. The present stand of saw timber is about 223 billion feet, or 10 per cent of the cntire stand in the country. Practically all of it is softwoods. The stand is very unevenly distributed. Nearly 60 per cent, or 130 billion feet, is in Montana and Idaho; 18 per cent, or 39 blllion feet, Is in Arizona and New Mexico; 11 per cent, or over 25 billion feet, is in Colorado; and the remainder is distributed in smaller quantitles among the other States of the region.

\section{THE ANNUAL DRAIN UPON THE FOREST.}

The annual cut of saw timber is about $1 \frac{1}{2}$ billion board feet, besides at least half a billlon feet for ties, posts, poles, and fuel wood, making the total annual cut about 2 billion feet. This, also, is unevenly distributed. Montana and Idaho together have an annual lumber cut of over 1 billion feet; Colorado, Wyoming, and South Dakota together produce not over 150 million feet; and some 170 million feet is cut in Arizona and New Mexico. Besides the cut there is a loss of saw timber tlirough fire, insects, and disease. In Idaho and Montana, where tires are most destructive, the annual loss from fire bas recently averaged about 1,100 million board feet. The annual loss due to insects and diseases in these two States ls estimated at about 100 million feet. For the entire region the loss from tire, insects, and disease is at least $1 \frac{1}{2}$ billion feet. The total annual drain upon the forests is about $3 \frac{1}{2}$ billion feet, twothlids of which falls upon Montana and Idaho.

\section{ANNUAL GROWTH.}

The anuual growth in the Rocky Mountalns is estimated at 461 million board feet of saw timber and 264 million eubic feet ln the form of immature stands (equivalent to about 528 million board feet), which makes a total of nearly 365 millon cubic feet (equivalent to ahout 989 million board feet), or 21.5 cubic feet per acre per year on the growing area. Most of the growth is in Montana and Iaalio.

\section{CUT COMPARED WITH GROWTH.}

Considering saw timber alone, the annual drain is about seren times the growth. If we compare the cut of all forest products with the entire growth in cubic feet, the cut and devastation is two and one-half times the growth. 
LOCAL NEEDS.

In Montana and Idaho the present eut of saw timber is in excess of the local needs, which are about 850 million board feet. Arjzona and New Mexico are not self-snstaining. In 1914 about 350 mlllion board feet of timber was used and only 132 miliion feet was produced. Wyoming, although it produces more than 600,000 rallroad ties and a large number of poles, posts, props, and mine ties, manufactures oniy about 15 million feet of lumber, less than enough for its population. Colorado, although it produces 550,000 rallroad tles and large quantities of posts, poles, props, and mlne ties, manufactures less than 100 million feet of Jumber, and is not self-sustaining.

\section{THE FUTURE OF THE LUMBER INDUSTRY.}

Of the Rocky Mountain States, only western Montana and Idaho now produce fumber above their needs and can Increase their output in the near future. It would seem that the forests of Montana and Idaho, with some 130 blllion feet of saw timber and a present cut of only 1 billion; Colorado, with over 25 billion feet and a cut of 100 million; Arizona and New Mexico, with 39 billion feet and a cut of only 132 million, are capable of sustaining a larger lumber industry for a considerable time.

It should be remembered, however, that the region is still underdeveloped and that its requirements for lumber may also be expected to increase with its rajidly growing population. Furthermore, within the next 12 years over 95 per cent of the existing sawmilis in the southern yellow-pine region will cut out. The Pacific coast and western MIontana and Idahe will have to assume the main burden of supplying saw timber to the entile country. This means nore rapld cutting of the remaining stands and a big increase in the existing defieit in annual growth. A large amount of the standing timber is relatively inaccessible. The future supplies of accessibie timber are therefore much more limited tlian is indicated by the estimates of the total standing timber. The privately owned timber in the territory tributary to Spokane will be eut out in 25 or 30 yoars if the present rate of cutting continues; and the cut, which now amounts to upproximately 550 million feet of logs, will drop to 100 or 125 milion feet, which the local National Forests can produce annually on a continuous basis. The lum. ber industry will then move to other timbered regions. probabiy to the Ciearwater territory, which is tributary to Iewiston, Idaho. Even if the rate of consumption should not increase abere the present figure, it appears that the bulk of Idaho's privately owned timber, ineiuding 75 per cent of the remaining white pine in the United States, will be gone in about 40 years.

The western red cedar is now being eut extensively in Montana and Idaho for poles, piling, posts, and shingles. The present average annual shipments of poles, piling, and posts from Montana and Idaho amount to 216,360 poles and piling and $8,789,000$ posts. The regions which are now being exploited will probably be exhausted wlthin the next 20 years and operatlons will be transferred to more remote areas. The present cedar jumber prices have diverted into lumber a large portion of the materlal ordinarly manufactured into posts and shingles. Continuation of this demand might easily exhaust the entire avaliable supplies of post and pole material in 20 years.

The future of the lumber industry in western Montana and Idaho will not be unlike that of the Paclfic Northwest. There is this difference, however, that the supplies in western Montana and Idaho are much smailer than those in Washington and Oregon, and comprise three-fourths of the remaining supply of one of the most valuable softwood timber trees of the country-western white pine. Now that the eastern white pine is practically exhausted, the demand upon the western species will tend to increase. The other States of the Rocky Mountain group will not be important factors in the lumber production for the general market.

\section{PACIFIC COAST.}

\section{GROWTII OF THE LUMBER INDUSTRY.}

The development of the lumber Industry on the Paclic coast, our last great couiferous timber reserve, has already progressed far. The first sawmill in the Northwest began operations on Puget Sound in 1845. Within a decade jumbering became, and stlli is, the chief Industry in western Washington. The cut for a good many years was used locally or shlpped into Californla or exported. Not very much timber was cut unt1l after the completion of the Northern Pacific IRallway in 1832, and then fol a number of years only in special grarles. Twelve years later lower freight rates were made on eastern lumber shipments and the pronounced development of the west coast industry began.

Very little lumber was eut in California prior to the beginning of gold mining in 1849. Lumbering in the redweorl belt began about 1860 and grew sterdily. In 1899 Washington, Oregon, and Callfornia cut a little more than $2,900,000,000$ board feet. Production increased slowly until in 1918 the total was slightly in excess of $8,590,000,000$ board feet. Washington became the leading State in lumber production in 1905 and has sinee held this place, except only in 1914, when it fell slightiy bejow Louisiana. The present cut is about 4,500,000,000 board feet annually. Oregon at present is the third State, with a lum. ber cut for 1918 of a little more than $2,700,000,000$ beard feet. That for California has never exceeded $1,500,000,000$ feet.

In the 12 years between 1906 and 1918 the cut of the IVest Coast increased only about $1 \frac{1}{3}$ billion feet, largely because of the inability of the product to displace southern pine in the eastern and middie western markets under the handicap of higher freight rates. Within the last year, however, shipnents have increased and yellow-pine markets up to the very boundaries of the producing territory have been invaded.

\section{ORIGINAL AND REMAINING FORESTS.}

The eolnmerclal forest area of the Paclfic Coast States has been reduced to approximately $57,586,000$ acres. A jarge percentage of this, about $39,370,000$ acres, is in virgin stands, not all, howerer, of accessible high-grade timber, for there is a large percentage of relatively inferlor and inaccessible areas. This is an important factor which is usually overlooked in the consideration of the western timber supply. Second growth of saw-t1mber size cover's about 5,292,000 acres and smaller second growth $6,425,000$ acres, while nonrestocking areas cover $6,500,000$ acres.

Of the volume of the original forest no satisfactory statistics are available. The present stand, however, is about 1,141, 031 million board feet, or practically half of the remaining saw timber in the United States. Oregon leads with a total stand of 493,700 milition feet; that of Washington is 334 billion; and that of California, 313,331 million. Six hundred and eightysix bilition, or more than half of the total, occurs in the Douglas fir belt of western Oregon and Washington.

Douglas fir coniprises 558,571 million fect, and of this 505 billion, or nearly one-fourth of the remaining stand of saw timber in the United States, is in Washington and Oregon. Estimates by species are as follows:

Douglas fir

Western yellow pine and Jeffrey pine

Western hemlock (largely in western Wasilington and Oregon)

True firs

liedwood (California)

Sugn pine and western white pine (largely sugar pine in Californla)

Western red cedar (western Washington and Oregon)

Spruce (Washington and Oregeni)

Lodgepole pine Others

Board feet, lumber scale. $558,571,000,000$ $183,453,000,000$

$94,000,000,000$ $82,479,000,000$ $72,208,000,000$

$38,485,000,000$

$49,000,000,000$

$13,35 \overline{5}, 000,000$ $4,566,000,000$ $44,914,000,000$

Total $1,141,031,000,000$ 
GROWTH AND DEPLETION.

The total area cut over is approximately $6,125,000$ acres, of which two-thirds is in Washington and Oregon, and a very large perccutage west of the Cascades in the Donglas fir belt. As already indicated, the total nonrestocking area of the Pacific Coast States is estimated at $6,500,000$ acres, but this is only a part of the sum total of depletion, since there has been great and needless loss from the destruction of virgin stands by fire and other causes on a part of the $6,425,000$ acres now supporting second growth. The area burned over annually in these three States is shown by Forest Service data to amount to 450,000 acres, and the loss in timber to about $600,000,000$ board feet.

The arerage annual cut, largely lumber but including relatively small amounts of other materials, is about 10 billion board feet. To this it is probably safe to add 11 billion feet lost by fire and other causes. It is also probably safe to assume that 11 billion feet out of the total represent the drain upon saw timber. Annual growth is estimated at 1,262,000,000 board feet. There is in addition growth of approximately $430,000,000$ cubic feet in stands of unmerchantable size. Total growtl in cubic fect amounts to $706,000,000 .^{\text {13 }}$ One reason for these comparatively low figures is, of course, the fact that so much of the territory is occupied by virgin stands. Total depletion in cublc feet amounts to $2,500,000,000$. Depletion is therefore approximately three and one-half times the growth. The depletion in timber of saw timber size is approximately nine times the growth of the same class of material.

\section{LIFE OF THE INDUSTRY.}

The tlmber stand in California is estimated at $313,331,000,000$ bosrd feet. This is being reduced by cutting at the rate of about $1,500,000,000$ feet annually. These figures should not be taken alone, however, for there are other important aspects of the situation. Increased demands from the East will almost certainly result in an increased rate of cut for Callfornia. Practically all of the cut up to the present has been in the most accessible stands, whereas a considerable part of the remaining timber is comparatively inaccessible.

Logging operations are now removing annually a little less than 2 per cent of western Washington's timber and less than 1 per cent of western Oregon's timber. Yet the reasonably accessible timber and that in private ownership is going very much faster, and with decreasing southern pine production enormous pressure to increase the cut may be expected.

A study of the local timber supply indlcates that in certain localltes a large proportion has been cut off and that logging operations are being pushed back to the less accessible timber in the rougher mountainous regions. The exhaustion of local supplies is a vital matter to local prosperity and derelopment. It means the cessation of a local industry, the abandonment of improvements, rapid depreciation of investment, and other losses which the industry, the community, and the consumer must shoulder. One authority estimates that only a third of the original privately owned timber tributary to Puget Sound remains. The situation in Grays Harbor County illustrates the rapid exploitation which in a surprisingly short time is to end the industry locally. About 20 years ago there were in this county $\mathbf{7 5 0 , 0 0 0}$ acres of timber and only about 75,000 acres of cuttings. Now there are 355,000 acres of stumps. One-sixteenth of the county's private timberland is being cut orer annually. In 25 years the supply of privately owned virgin timber will be gone.

King and Snohomish Counties, Wash., the scene of the earliest lumbering operations in tlie Northwest, also illustrate local exhaustion of virgin timber in the not very remote future. Forty billion of the original 80 billion feet of commercial timber

12 Equivalent to about 2,100,000,000 board feet. has bcen cut. Thirty billion of the remainder is in private ownership, and is now being felled at the rate of $800,000,000$ feet annully. Indications are that this private timber will be gone in about 35 years.

One authority on the lumber supplies of Washington has studied the rate of exhaustion from the annually decreasing acreages of private land assessed as "timberland." He found that from 1909 to 1919 there was a decrease in the acreage of timberland in western Washington of about 850,000 acres, or 85,000 acres annually, and in eastern Washington of about 390,000 , or 39,000 acres annually. On the basis of $3,585,686$ acres assessed as timberland in 1919 in western Washington, privately owned old-growth timber would last 42 years at the present rate of cutting. Similarly, in eastern Washington, for the $1,128,666$ acres of private timberland in 1919 , the present rate of cutting would exliaust the virgin timber in 26 years. Adjusting these statistics to provide for additional land whlch was classified as timberland in 1919 but not in 1909, he belleves that an even faster rate of cutting of the private stumpage is indicated, and that, disregarding increment in second-growth stands and witlout allowing for the expected increased cut, the private virgin timber will last only 35 years in western Washington and 20 years in eastern Washington. Allowing for the alınost certain increased rate of cutting, he expects the privately owned virgin timber supply of Washington to be virtually gone in 20 years unless forest policles are changed.

Bend, Oreg., is the center of one of the most extensive and famous of Oregon's yellow-pine belts. A few years ago an unbroken forest of virgin yellow pine extended to the very edges of the city. At present cutting has left a practically unbroken waste for 6 or 7 miles to the west and south. The operating territory surrounding Bend has a radius of from 20 to 30 miles and occupies an area of 382,000 acres of merchantable forest, carrying $5 \frac{3}{4}$ billion feet of commercial timber. of this about 231,000 acres, carrying $3 \frac{1}{2}$ billion feet, is privately owned. The present rate of cutting, which is likely to continue and may be augmented, will exhaust the privately owned stumpage in 25 to 30 years.

Depletion in Washington has gone much further than in Oregon, and while an expansion of the industry in Washington under increased demands from eastern markets may reasonalbly be expected, by far the greater part of the expansion may be looked for in Oregon. The renson for the slower development in Oregon lies in the greater inaccessibility of its Douglas fir. stands. Many operations now being seriously considered for Oregon will require transportation and other investments running into the millions of dollars before any timber can bc taken out.

The factor of local consumption must also be considered. California is an example. Its industry is large and promises to grow. From the earliest days California has been an important source of export material. Largc quantities are still exported to the East and to forelgn countries; but up to the present time the Statc's population and agricultural and industrial development have more than kept pace with the output of lumber, so that it is doubtful whether production has exceeded consumption since about 1875. From the heginning of lumbering on Puget Sound California has imported large amounts of fir. 'The per capita lumber cut of the State has been approximately equal to or slightly in excess of the average per capita consumption of the United States slnce between 1869 and 1879, while the average consumption of the State is probably somewlint greater than for the country as a whole. In 1919 southern Califormia alone used the equivalent of about half the total cut of the State, a per capita consumption of at least twice that of the whole United States.

The lumber cut for the Pacific Coast States as a whole will undoubtedly increase very materially during the next 10 years. 
Local demands will also Increase, but not in proportion to the cut. Large additional amounts will be available for the castern markets. A gradual rise in logging costs is inevitable as the more accessible stands are cut out and it becomes more and more necessary to extend operations to the rougher mountainous logging chances, with lighter and more broken stands and larger percentages of the less desirable species. The timber resources of the Pacific Coast States are very large, but it would be very unvise to overestlunate them, for much less than the total stand is readily available. Exlsting transportation facillties to the liast are already overburdened wlth present traffic, aucl they will have to be very materially increased to neet the probable reduction in the eastern and southern inmber cut during the next 10 years.

\section{THE SOUTHERN APPALACHIAN HARDWOODS.}

\section{GROWTH AND DECLINE OF LUMBERING.}

For the purpose of this report the southern Appalachlan hardwood region includes the hardwood forests of Maryland, West Virginia, Virglnia, North Carolina, South Carolina, Georgia, Alabama, IEntucky, and Tennessee.

Large-scale logging operations shifted to this territory from Pennsylvania, Ohio, and Indiana. Operations in West Virginia on a large scale dld not begin until after the Civil War. Before 1900 centrai Kentucky and Tennessee were well cut over. The cut for the entire region was at abont the maximum in 1909 , with an output in hardwood lumber of approximately 4 billion board fect. Following this there was a pronounced decline, and in 1918 the cut had decreased to $1,700,000,000$ feet. While this heavy falling off in cut was, of course, very largely due to war conditions, there has been a decrease in proportion to the total hardwood cut of the country, for whlch the depletion of supplies appears primarily responsible. The proportion of the aggregate hardwood lumber production which was supplied by the Appalachian States had risen gradually from 32 per cent in 1899 to 41 per cent in 1914, but by 1918 it had fallen to 34 per cent. West Virginia, which held the lead in hardwood production from 1910 to 1917 , lost it to Arkansas in 1918; while North Carolina, which cut approxlmately 400 million feet In 1909, dropped to less than 200 million in 1918.

The cut has declined in quality as weli as quantlty, and this Is perhaps the more serious aspect. The early Iumbering consisted of cullings in which only such trees as walnut, cherry, and the finest of oak and yellow poplar situated along the drivable streans were removed. The introduction of logging rallroads extended operations into nearly all parts of the region, until now there is comparatively little virgin timber left, most of It remote and difficult to log. The present logging operations are largely working over prevlously-culled stands, removing practically every saw $\log$ and a large part of the smaller material. The quality of the lumber produced is consequentiy much poorer tlian formerly.

\section{TIE ORIGINAL FOREST.}

The virgin forests which once covered practically the entlre land area of this region contained a wealth of hardwood timber unsurpassed in the Northern Hemisphere. Oak, chestnut, and yeliow poplar of large size and high quality flled the coves and valleys, mixed with walnut, cherry, hlckory, basswood, cucumber, and other valuable hardwoods, and softwoods such as white pine and hemlock. Over an area exceeding 60 million acres the origInal hardwood stand may be estimated at more than 325 blllion feet.

\section{THE REMAINING STAND.}

Lumbering and settlement gradually restricted the area of commercial timber to the mountains. This part of the region, about 35 million acres, now contains practically all of the remaining tracts of old-growth hardwood timber, and the extent of these lias been reduced to about one-third of the total area, the remaining two-thlids being either in recently cut-over land, usually badly burned, or In farmers' woodiands. So far as can be learned from the avallable sources, the stand is In the neIghborhood of 80 bllion board feet, of whlch 60 blllion is old-growth timber occupying abont 12 million acres. Most of this has been eulled of its best trees, and the virgin tract: which remain are few, relatively small, and remote. About 12 per cent of the stand Is spruce, hemlock, and varlous plnes. The oaks are the princlpal hardwoods and probably comprise about 35 per cent of the stand, while chestnut is the most abundant single species and Is estimated at 25 per cent.

For all the States within whlch the southern Appalachlan Mountains lie, the total stand of hardwoods is estimated at 147 bllion board feet, about 58 per cent of the total stand of both softwoods and hardwoods. Outside of the mountain region the stand is practically all second growth in farm woodiands. The total area bearing hardwood stands Is about $55 \mathrm{mil}$ lion acres.

\section{LUMBER CUT AND TOTAL CUT.}

During the two years preceding our entrance into the war the annual hardwood lumber cut of the southern Appalachlan States fell from about $3 \frac{1}{4}$ to abont 21 blllion board feet. In 1918 there was a further reduction to less than 2 bllifon board feet. Under normal conditions it is ilkely that the cut of iumber would still be proceeding at close to 3 billion board feet per year. The lumber cut, however, is probably only about 35 per cent of the total drain upon the forests. An immense amount of material is taken out in the form of tanning-extract wood and bark, poles, ties, cooperage stock, fuel, and other products. Expressed in terms of cubic volume, the "normal " annual Iumber cut is the equivalent of 657 million cubic feet of standing tlmber, while other products consume an additional 1,220 million cubic feet, making a total annual production of about 1,877 million cubic feet. Much of this output is, of course, from second-growth timber. Of the Iumber output, however, fully 75 per cent is from the remaining old-growth stands. After the exhaustion of the old growtin the entire supply of Iumber must come from the second growth, and since very little of this will rield lumber of a better quality than No. 1 common, the effect upon the furniture and other industries largely dependent upon high-grade lumber will be very serious.

\section{DETERIORATION OF THE FOREST.}

The chestnut blight has entered the mountaln region, and in the opinion of pathologists is almost certain to sweep througi the hardwood forests, eliminating chestnut. Besides depriving the tanning and other industries of one of their chief sources of supply, this disease will throw the burden of the lumber cut npon other species, thus hastening the process of depletlon. It Is impossible to forecast the rate of this depletion.

A further loss which can not be measured satisfactorily in amount of material or money value is that from forest fires. Much of the mountain forest has been repeatedly burned, and whlle not much timber has been actually killed the fires are responsibile for a great deal of deterioration in the timber.

\section{THE DURATION OF THE CUT OF OLD GROWTH.}

Much uncertainty exists in the minds of even the best-informed men in the lumber industry as to the duration of the cut in the remaining old-growth stands. In West Virginla, which has been one of the leading hardwood producing States, the statement was made by one of the best-informed men in the industry that the length of cut on a large scale would not exceed five years. The manager of one large company reports that most of the mills of the State will cut out within five to eight years. A responsible official in another company states that very few concerns in his section of the State have over 
five years' cut. In North Carolina the State forester estimates that the supply of old-growth hardwood timber will last 17 years. One of the best-informed Jumbermen in western North Carolina estimates that the cut from old-growth timber in north Georgia and southwestern North Carolina will last 20 years, but that this cut w111 cone Increasingly from small operations.

In Kentucky and Tennessee the duration of the cut of oldgrowth hardwoods is believed by the manager of one lumber company to be 20 years, while another well-informed man. sees 15 years ahead for tile Kentucky hardwoods. A future cut of 15 years is predicted for old-growth timber in the soutiern Appalachians by another representative of the industry, while still another estimates that the supply wili last 25 yoars.

The consensus of opinion among the best-informed men in the industry seems to be that if present conditions continue the southern Appalachians will have ceased to function as an important source of higli-grade hardwood lumber within 20 years and that within 25 years the old-growth timber will be practically gone.

\section{EFFECT OF DEPLETION UPON SELECTED INDUSTRIES.}

Further light is thrown on the extent of the deptetion of the southern Appalachian old-glowth harlwoods by a questionnatre to the wood-using industries of North Carolina by the State forester. IReferring to local supplies at the vresent time in comparison with conditions extsting during the past 10 or 20 years, 93 per cent of the fumiture inakers, 91 per cent of the vehicle makers, and 100 per cent of the cilail makers reported that supplies had been greatly reduced. In referring to prospective local supplies on the basis of a 10-year outlook, 12 per cent of the furniture, 22 per cent of the vehicle, and 43 per cent of the chair factories reported that supplies would be exhausted. Eighty-elght per cent of the furniture, 67 per cent of the vehicle, and $\mathbf{5 7}$ per cent of the chair makers reported that supplies would be gradually reduced. Of all of these onty 11 per cent of the vehicle factories reported an outlook for sufficlent material.

The replies received from the furniture manufacturers indicate a marked decrease in the use of oak and poplar as compared with gnm. In 1909 the fumber used was 74 per cent oak, 13 per cent poplar, and 1 per cent gum, while in 1919 the percentages of oak and poplar used had been reduced to 60 and 6 per cent, respectively, whlle gum had increased to 21 per cent. The manufacturers indicate that the present year will see a st11l larger proportion of gum used.

\section{THE ANNUAL GROWTH.}

There are about $22 \frac{1}{2}$ millton acres of second-growth hardwoods of saw-tlmber size in the southern Appalachlan States, which are estlmated to be producing about $1 \frac{1}{2}$ billion board feet per year, equal to about 325 million cubic feet of standing timber. In addition there are approximately 223 million acres which are prodiscing hardwood material of only cordwood size. The annual growth on this area is about 570 million cublc feet. The total growth is thus about 900 million cubic feet.

GROWTH COMPARED WITH CUT.

Growth is about one-half the "normal" rate of cut:

\begin{tabular}{l|r|r|r}
\hline & $\begin{array}{r}\text { Estimated } \\
\text { annual cut } \\
\text { ("normal"). }\end{array}$ & $\begin{array}{r}\text { Estimated } \\
\text { annual } \\
\text { growth. }\end{array}$ & $\begin{array}{r}\text { Growth in } \\
\text { per cent } \\
\text { nf cut. }\end{array}$ \\
\hline $\begin{array}{r}\text { Lumber, board feet.................. } \\
\begin{array}{c}\text { All products, inchuding lumber, cubic } \\
\text { feet.................................. }\end{array}\end{array}$ & $3,000,000,000$ & $1,490,400,000$ & 50 \\
\hline
\end{tabular}

1 In terms of lumber, thls corresponds to an annual eut of about $5,440,000,000$ board feet and an annual growth of about $2,630,000,000$ board feet.
In contrasting these figures, however, it should be remembered that much the greater part of the cut is being taken from the relatively concentrated old-growth timber, while the growth is taking place in the widely distributed stands of ceond growtil. The cut is from large timber yielding highgrade lumber; the growth is nearly all low grade because of the smill size of the trees. Great damage is constantly belug done by forest llres, while the second growth itself is being drawn upon more and more for a whle variety of small wood produets.

IMPORTANCE OF THE SOUTHERN APPALACHIANS IN THE FUTURE LUMBER SUPPLY OF TIIE COUNTRY.

'The ruture production of the Apualachlan lardwood region is of far more than furely local importance. The hardwood forest lands of Ohio, Indiana, and Illinols, which snpplied 25 per cent of the total hardwood lumber cut as late as $\mathbf{1 8 9 9}$, have been converted into farms almost as fast as the land has been cleared, and small isolated tracts, as farm wood lots. will furnlsh the only future timiner production. Hardwood lumber production is now centered in the lower Mississippi Valley, and the cut is almost entirely from rich agricultural lands from which timber production can not be expected in the future. larm woods will continue to contribute, but if there 1s to be any permanent snpply of large-stzed, high-grade, hardwood saw timber it must come very largely from mountainous, rough, or otherwise nonagricultural lands like those in the southern inountains. Aside from relatively small areas in the Lake States and in New lingland, the ent1re country must look to the southern Appalachians.

\section{HARDWOODS OF THE LOWER MISSISSIPPI VALLEY.}

\section{AREA AND STAND.}

The lower Mississippi Valley, including the States of Arkansas, Mississippi, Lonisiana, eustern Texas, and eastern Oklafoma, constitutes the last great reservoir of hardwonds in the country. Of the hardwood area of $30,000,000$ acres in this region, 60 per cent, including the heaviest stands and most rahable species, is located on the alluvial bottoms of the Mississipp1 De]ta. Most of this is unusualty fertile and will eventually be cleared for agriculture. The remaining 40 per cent, of upland stands, is of less 1mportance from a lumber standpoint, both because of the smaller trees and great mixture of species and hecuuse mruch of it is broken up by farms and pine stands.

Altogether the region is estimated to contaln nearly 133 billion board feet of saw timber, or more than twice as much as the present stands of old-growth hardwoods in either the Lake States or the southern Appalachians. With the exhaustion of the hardwood supplies in these regions, the lower Mississippi Valley is being drawn on luore and more heavily to furnish the raw uaterial for the hardwood-using industries of the entire country.

\section{DEVELOPMENT OF THE LUMBER INDUSTRY.}

During the period from 1900 to 1906 the cut of hardwoods in Ohio, Indiana and lllinois, which had previousiy contributed large quantities to the vehicle, furniture, raliroad-car, and other hardwool-consumhng industries, fell olf by nearly 50 per cent. By 1906 the centel of hardwood production had shifted to the Aptalachian States, which furnished nearly half of the country's hardwood consumption, while nearly one-fifth came from the Lake States. Now these reglons in turn are declining in production, and there is a corresponding increase in the cut of the lower Mississippi Valley. The expluitation of hard. woods in this region has progressed steadily since 1900 , its contribution to the total hardwood cut increasing from 14 per cent to approximately 25 per cent. To-day the hardwood 
produets from this region are being used to supply the factorles of the Carolinas, the Ohio Valley, and the Lake States, which were formerly independent of imported materlal.

The last of the great lardwool regions is thus well on its way toward complete exploitation. Alrearly the exhaustion of the original supplles in the northern part of the region centering around Memplils has reached the point where it is profitable to return to cut-over areas for trees that were formerly regarded as too small to $\log$ and for less valuable specles, such as tupelo and water gum, which at the time of the hirst cutting were unmerchantable but which now command a ready sale. The present practice in this part of the region is to remove all specles. Wood distillation plants have been Installed for using cordwood and there is a steadily increasing interest in the utllization of smaller sizes, Inferior trees and logs, and species formerly rejected. The duy of the small mill and wood-products plant lias arrived. More and nore the large mills are finding themselves forced either to buy logs in order to continue operatlon or to move down river Into southern Mlssisslppi and Jouisiana where new plants can be erected with reasonable prospect of a 20 to 25 years' supply of material.

In the southern part of tile territory, In southern Mississippi, Louisiana, and enstern Texus a much larger proportlon of the origlnal forest is left. Here large mills are still the rule and are lncreasing in number and in rate of exploltatlon. It is therefore llkely that increased production in this part of the region will lead to an lncreuse of the present annual cut of approximately a billion and a balf board feet of hardwoods for the region as a whole. How long it will last can not, however, be definitely predicted. The one thing certain is that eventually the southern part of the region will repeat the history of the northern part and that the virgin stands and large mills of to-day will be replaced to a large extent by portable mills olverating culled and seconl-growth stands.

\section{GROWTH AND DEPLETION.}

Since the region is largely agricultural in its future possibilitles, comparatively little In the way of tlubel growth can be looked for. The extent to which it is drawing on ils forest cupital is of great importance, because it is the source of our largest remalning liardwood supply. A net growth is taking jlace on only some 6.5 million icres carrying hardwoods of sawnimber size. The annual growth on this area is estlmated at "1pproximately 395 million board feet, or but little more than one-fourth of the normat anmual lumber cut of 1,500 millon board feet. In addition there is an nunual growth of 301 million cubic leet (about 602 million board feet) on the 15 million acres with stands below saw-timber size, making a total growth for the region of 387 million cubic feet (about 997 million board feet).

In addition to the depletion In quantity of material there is a depreclation In the quality of the remaining stand. Of the 36 million acres of liardwood lands in the region, approxlmately 22 million acres are contained in the alluvlal bottom lancis of the Mississippi Delta. It is on these alluvlul solls that the heaviest and finest stands of hardwoods remain, particularly oak, red gum, asl, and cottonwood, whlch in 1918 made up more than 50 per" cent of the reported ent of hardwoods for the entire country. Oak and red gum are now being logged most heavily and in 1918 made up more than two-thlrds of the total hardwood cut in the region. These species, becanse of the demand for them in the vencer industry, are two of the most highly prlzed hardwoods of the Soutl, but they are valuable for veneer only when cut from virgin stands and in large slzes. With the rapid depletion of the present vlrgin stands there wlll therefore be a corresponding quality sliortage, which will result in a relatively larger proportion of the future cut being made up of such secondary species as syca- more and tupelo and of poorer specimens of the more valuable sifecies, such as uak ant gum.

\section{THE FUTURE OF THE REGION.}

This steady depletion of the hardwoods in the lower Misslssipil valley is accentuated by the fuet that the bulk of the bottom-land stands ure on some of the most fertle farm solis in the cumitry. With the removal of the timber they wlll, for the most jart, be levoted to agrlenlture. Dralnage and clearing of the cut-over lamis las been golng on for more than a decade at a rate wilich indlcates that not over 10 per cent, and probably less, of the area once under harrwoods wlll be allowed to come ill) to second growtl. 'Thls change in the use of the land, whlch ls of course in accordance wlth its hlghest utllization, means that the cut ln the bottom-land region of the lower Misslssippi Valley can not be malntained from second growth to the same extent as has been the case in the Northeastern and Central States. Once the present stand of timber on these bottom lands is gone, the hardwood supply of the country wlll be permanently reduced, ind the future cint of hardwools must cone from second-growth stands of relatively inferlor (fuallty in other parts of the country.

\section{NEWSPRINT SUPPLIES.}

\section{THE FACTS AS TO DEPLETION.}

Newsprint paper is one of the leading products of the pulp and paym industry, whlch in Its modern development depends upon the forest for its raw materlal. The present newsprlnt shortage goes back fundamentally to our dependence for newsprint production upon the forests of the Northeast and the Lake States, where timber supplies have already been serlously depleted, and where, consldering the remalning stands, the pulp and paper industry is already serlously overdeveloped.

Until the abnormal demands, short supplles, and resulting prices of the past few montlis led to lncreased newsprint productlon throngh the utllization of plants deslgned for and formerly used in making other kinds of paper, there had been no expansion in the newsprint Industry ln the United States since 1909. The demands for newsirlnt paper had, however, been increasing by leaps and bounds. In 1899 our consumptlou amounted to 569,000 tons. In 1918 it liad reacled $1,760,000$ tons, an inerease of approximalely 200 per cent. Per capita consumption of 3 pounds per person in the United States in 1880 bad increased to 33 pounds per person in 1919. With an lncrease of 11 times in 40 years, rapidly incleaslng requirements between 1909 and 1919, and very little Increase ln productlon, Imports were obviously necessary.

Before taking up the extent to which the Unlted States is supplying its domestlc requirements, the Importance of the country's being on an independent bisis so far as newsprint production and the necessary raw materlals are concerned should be briefly considered. Dependence upon forelgn sources for jull wool or pulp newsprint exposes the American consumer to the langer of price control. He must also reckon with the possibllity of embargo, whlch even now is far from being a theoretical menace. All exports of pulp wood are prohlbited from the colony' of Newfoundiand. The Canadian Provinces have prohibited the export of pulp wood from crown lands, which form a very considerable extent of the timberlands both in eastern and western Canada. For a year or more Amerlcan manufacturers have been apprehensive concernlng the possibllity of embargo on all pulp-wood exports from Canada. It would unquestionably be desirable to make the United States as nearly selfsupportlng as posslble.

In lumber the United States is still an exporting country, but in pulp wood, pulp, and newsprint we liave become large importers. From being self-supportlng in newspr"lnt production as late as 1909 the Unlted States had, In 1919, 10 years later, 
become dependent upon foreign sources for approximately twothirds of our newsprint or its raw material.

The factors which have held our newsprint industry practicaliy at a standstill in the face of rapldly growing domestic requirements are pertinent in a study of timber depletion. The various requirements of paper making have restricted the number of specles which have, gone into newsprint paper, and incidentally into all kinds of pulp and paper, very largely to four, of which spruce supplled 55 per cent of the total pulp manufactured in 1917, hemlock 16 , balsam 7 , and poplar 6 , a total of 84 per cent from four species. The overcentralization of the Industry in the Northeast and Lake States and the consequently serious overcutting of the timber in these regions is due in no smali degree to this restricted use and the occurrence of these species chiefly in New England and the Lake States.

The lumber industry has followed the timber, but a much smaller investment per unit of output is required in the lumber mill than in the pulp and paper plant. On a prewar basls an investment of approximately $\$ 1,500$ per thousand board feet of dally product is required in lumber manufacture, whereas pulp and paper establishments require approximately $\$ 50,000$ per thousand feet of daily consumption. Large investments have therefore tended to hold the pulp and paper industry in the regions in which it was first established, and timber has been hauled increasing distances to the mills. A rail and water transport exceeding 500 miles is now not uncommon.

When overdevelopment of the American industry in the Northeast and the I،ake States, as compared with timber supplies within our own borders, prevented further development, and when Canada began to take measures to withhold pulp wood for the upbuilding of a home industry, new construction to meet growing demands shifted to the other side of the international boundary, where It was welcomed by the Canadian and the various provincial governments. Since 1909, the year which marked the suspension in American development, Canadian production has increased from 150,000 tons to 800,000 tons, or approximately 433 per cent.

The depletion of supplies in the Lake States is clearly indicated in the rapidiy increasing distances from which the pulp and paper mills find it necessary to secure their material. A representative of one of the purchasing companies which supplies a large number of the Wisconsin milis reports that in 1904 supplies were largely obtained within the State. Five years ago it had become necessary to go far north into Minnesota, but it was rarely necessary to ship material from points more than 50 miles north of Duluth. At the present time, however, a very material part of the supply is secured from the extreme northern part of the State. Spruce from Minnesota is now being hauled from 700 to 750 miles by raliroad to the Wisconsin mills, and from Canada up to distances of 1,000 and 1,200 miles. The situation has become so critical that the Wisconsin mills are seriousiy considering the possibility of securing their raw materials from the Rocky Mountaln region of Montana. For hemlock the paper industry must compete with the lumber industry for logs of saw timber size, and, unfortunately, from the standpoint of future supplies, the cut now includes a very considerable amount of material obtalned from trees under saw timber diameters.

It is reported from New York, where nearly 50 per cent of our domestic newsprint production is now centered, that 60 per cent of the pulp and paper mills have absolutely no timber supplies of their own. For these mills there seems to be little ahead except closing in a comparatively few years. At least 60 per cent of the remaining spruce puip wood in New York is in the State preserves, on which no cutting is allowed.

In New Hampshire the coniferous pulp wood has been cut very heavily, and 10 or 12 years will probably see the end of the supply. Aside from the State preserve in New York, the bulk of the remaining coniferous pulp wood of the East is located in Malne. One of the best supplied pulp and paper companies in the State has holdings which at the present rate of cutting various estimates give a life of from 40 to 60 years. Holdings of another large company are estimated at about 20 years; of still another at 15 or 16 years. There are about 15 milis which have no lands of their own and which will probably have difficulty in purchasing material within 10 years.

The pulp and paper milis of the Northeast in general are becoming more and more dependent upon Canadian wood. So far as known, no company in the Northeast has sufficient holdings under present methods of management to guarantee anything approaching a continuous supply. Probably not over six companies control or own timberlands with supplies for more than 20 years.

The drain upon the forests for newsprint is very heavy. One large daily, for example, which consumes 20,000 tons a year, requires for that brlef period the product of a century's growth on 7,500 acres of eastern spruce forest.

The present situation from the standpoint of timber supplies in the eastern United States for the newsprint iadustry is therefore rely unfavorable, and the future holds no particular promise. The supplies already limited are being rapidiy cut; many unills a re already without timber of their own; the stands in eastern Canada have apparently been very much overestimated in the past; and little concerted effort has yet been inade to increase the production of pulp woods in the Northeast, where the industry is at present centered. Only such effort, together with the development of the industry in the West and in Alaska, where there are still large stands of timber suitable for newsprint paper, can assure production in the United States which will even approximate domestic requirements. The situation as to other classes of paper is somewhat similar, although it may not yet be so serious, and is usually of less importance from the standpoint of public welfare.

\section{ALASKAN SUPPLIES OF PULPWOOD.}

Alaskan timber is so important from a national pulp-wood standpoint that it can not be allowed to pass without special comment. The timber, which is of particular interest, is on the Tongass National Forest in southeast Alaska.

While much of this timber is of saw-timber size and will in the future become increasingly valuable for lumber, it is believed that its real future is for pulp and paper. The stands are largely western hemlock and Sitka spruce, species now in use on the Pacific coast for newsprint and other paper iuanufacture. It is estimated that there are in the Tongass National Forest in the nelghborhood of 70 billion feet board measure, in a comparatively narrow belt along the 12,000 miles or more of coast line. Water power is arallable, as is also deepwater transportation from numerous mill sites. This timber is for sale under practical and favolable terms and in amounts sufficiently large to justify the instaliation of plants. Since it is in a National Forest it will be cut under methods which will insure permanence of production.

It is estimated that the cut from this region alone will insure a perpetual supply large enough to meet one-half of the present newsprint requirements of the United States. There seems to be no reason why southeastern Alasia, sltuated in practically the same latitude as Norway and Siveden, should not become the center of a large pulp and paper industry which will be a source of local prosperity and of great national importance in the light of our present dependence upon foreign pulp and paper production. Alaska, in other words, is one of the centers to which the newsprint industry of the United States should look for a large future development. The same is true of other centers in the West, where immense sources of pulp wood supply are now almost wholly undeveloped. Much of this timber is in the National Forests. 


\section{THE MOVEMENT OF PRICES.}

Figure 2 sbows the trend of pulp-wood prlces in New England and contract newsprint prices and consumption in the United States since 1899. Spot market prices are shown for 1919 and 1920. Competillon among American mills and between the American and Canadian product kept down the contract price of newsprint untIl 1916, In spite of the increasing cost of pulp wood. Alother factor in keeping prices of newsprint down was the introduction of cheaper methods of manufacture, the effect of which was, In part, at least, to help to reduce prlces hetween 1900 and 1909.

The generai contract price level as represented by 100 per cent is $\$ 2$ per luundred pounds. This price levei obtained untll in 1916 the Increased demand for newsprint outstripped production, and compelition among purchasers for inadequate supplies succeeded that among produccrs to dispose of their product. Increasing demands and growlng competitlon among newspapers forced contract prices up to $\$ 4.50$ in 1920 . The

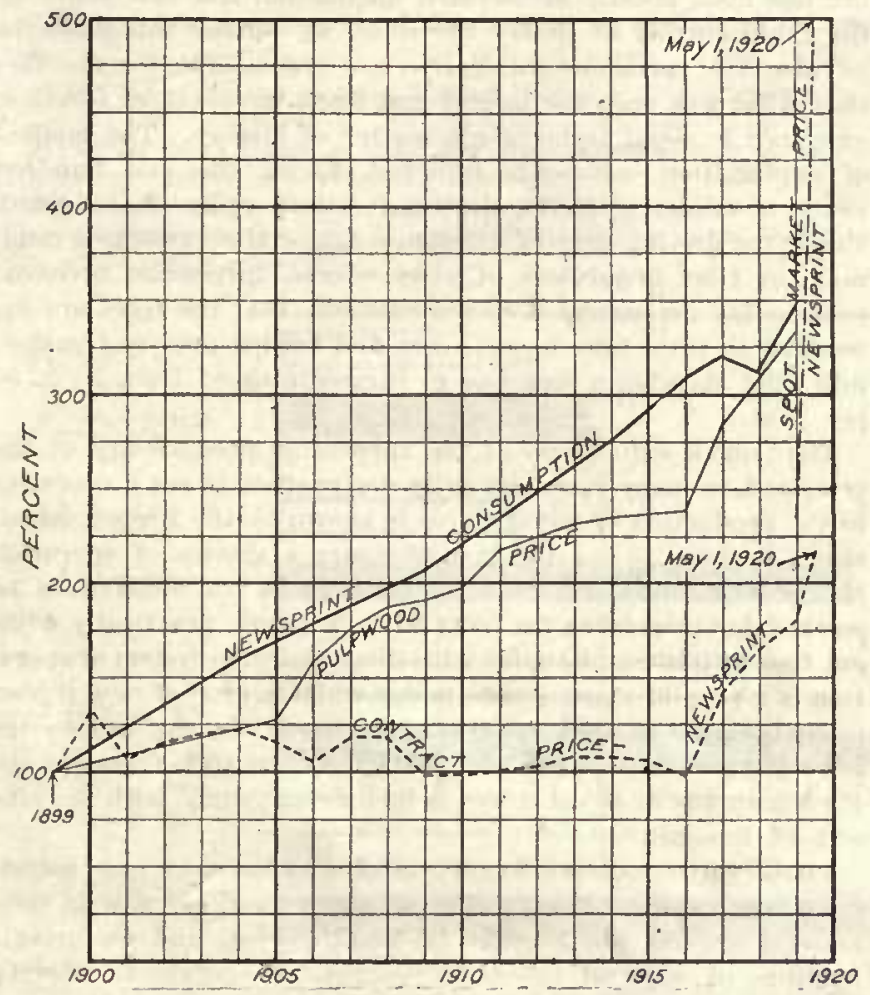

Fia, 2,--Rise of consumption and selling priees of newsprint in the United States and of the price of pulpwood in New Engiand, 1899-1920.

curre as it stands does not take one important factor into account. Prior to the war the contract price was f. o. b. point of consumption, but during the war contract prices were changed to f. o. b. paper inill.

Spot market prices are shown only during 1919 and 1920, hecause prior to that time they are rot available as separate quotations. In general, however, spot market prices before the war followed contract prices ciosely, and at times were even below them.

Prior to the war a relatively smail percentage of the totai newsprint consumption was handled on the spot-market basis. The larger ncwspapers particularly secured all, or practically all, of their suppiles under contract. During the last year the larger newspapers have found it increasingly difficuit to secure all of theil supplies under contract, and have been forced to secure the remalnder in the open market. It is in the open market that the fuil effect of competition for inadequate supplies is shown, and this is reflected in the much higier prices.
It is here that the speculative element in the handling of a necessary commodity at a tine of shortage is fully brought into play. Unfortunately it is upon the spot market that the smaller newspapers, least able to increase returns by Increasing advertising material and raising thelr advertising rates, must depend.

The depletion of timber supplles is first shown in competltion for pulp wood and steadily increasing prices. Competition among producers for the sale of their product resulted for a considerably longer period in keeping newsurint prlces at a fairly constant level. Only wlen the avallable timber supplies of the reglons in which the newsprint industry had been deveioped became so short as to prevent normal additions to plant capacity and demand for newsprint exceeded its produetion did newsprint prices advance. Depletion has resuited since 1899 in a large Increase in both pulp-wood and newsprint prices. It is merely the time when and rate at which the increase took place that bas varied.

\section{NAVAL STORES SUPPLIES.}

\section{DEVELOPMENT OF THE INDUSTRY.}

So pronounced is depletlon of the timber upon which our naval-stores industry depends for its supplies that it is commonly regarded as a dying industry in the United States. In colonfal days, when the wooden shipbuilding Industry of New England was of great importance, naval stores for domestic consumption, as well as for export, were secured from the pitch pine from Maine to New Jersey. The present-day navai-stores Inclustry dates back also to early colonial times, but uses the longleaf and slash pines of the South.

The very name of the industry is no longer appropriate, since the bulk of its products-spirlts of turpentine and rosin-are largely used for purposes having no connection with shipping. They are important constituents in such products as soap, paint and varnish, paper sizing, printing ink, greases, ofls and belt dressing, soldering flux, shoe polishes, roofing and linoleum, fly paper, sealing wax, clectrlcal supplies, matches, and various articles in the drug trade. The annual products of the industry exceed $\$ 40,000,000$ in value, more than half of which comes froni exports. Since the Civil War It has held a piace among the industries of the South inferior only to agriculture and lumbering. Since 1820 , or in fact since statistles of any vaiue are available, American production has led the world, and even at the present time is approximately 80 per cent of the total world production.

For the South as a whole, production has been falling off for a number of years. From slightly less than $34,000,000$ gallons of turpentine in 1899 , the first year of satisfactory statistles, it decined to approximately $17,000,000$ galions in 1918 , a decrease of 50 per cent. Rosin production during the same perlod fell a proportionate amount.

The average production of the last six years has been 25,000 ,000 gallons of spirits of turpentine and $834,000,000$ pounds of rosin, a production whlch has been easily absorbed by the worid's industrles.

\section{REMAINING SUPPLIES.}

A study of the opinions and estimates of a number of the bestinformed men in the industry, men representing every part of the territory and having more than ordinary means of information, indicates that there are not more than 31,000 crops of turpentine timber avallable and uncupped in the naval stores territory to-day. From this amount of timber it is estimated that not more than $166,000,000$ gallons of turpentine and 5,000 ,000,000 pounds of rosin can be produced. In addition to the uncupped supply of timber, that which has been or is now being worked will probably yield $60,000,000$ gallons of spirits of turpentine and $1,900,000,000$ pounds of rosin. making the total availabie supply $226,000,000$ gallons of spirits of tur- 
pentine and $6,900,000,000$ pounds of posin. Ous own markets and export demands wlll, it is believed, absorl) $25,000,000$ gallons of spirits and $825,000,000$ pounds of rosin annually. At this rate the supply of timber now in slght would be exhausted In less than 10 years. It will actually be extentied beyond thls perlod by the production of wood turpentine and rosin and also by the gradual falling off in the rate of production as the remaining timber supplies become exhausted. 'The indications are, however, that the production of gum naval stores in the southern pine belt will within 10 years have iseen reluced to such an extent that export markets and eren our own must look elsewhere for their main supplles.

The naval stores industry of the South las inigrated from State to State, following the tlmber. North Gilrolina, wlere now production is negligible, was for many years the leading State. South Carollna has been practically abandoned by the industry for more than 20 years. Itising pricas have induced a few operators to go back ovel the teruitory to work scattered second-growth stands and isolated patches of virgin timber, int it seems probable tirat these supplles will be exlatusted within four years. Well-informed men in the lndustry helieve that in from four to six years under present demands Georgia wili take its place with North and South Carollna as an insignlficant factor in production.

Florida has been the mainstay of narai stores production durlng the last 10 years, but the end of its supply is detinltely in sight. Of late the value of lts product has been more than twice as much as that of any other State, and nearly half the value of the naval stores produced in all Southern States. Falrly accurate data on the resources of wloridn have been compiled by some of the large naval stores Interests. "This information, checked by estimntes of well-informed operators in various parts of the State, indlates that at the current rate of production Florida cau not hold its own for more than elght years. That the State will soon be ibought to the positlon of North and South Carolina and Georgia is Improbable, since a very conslderable portion of the remalning timlser is held by strong corporations in large, well-blocked bodies, and it is to be expected that exploitation will be more conservative ano less wasteful and hurrled. It is the oplnion of the well-informed men in the Florida Industry that not more than 5,000 crops of uncupped timber avallable for operation remin in the State.

Nuch of the longleaf and slash pime of Alabmua las already been worked, and the greater portion of the remalning stani of uneupper timber is in the linnds of large lumber companies. Turpentine operators, judging from the present rate of lumbering, foresee a passible increase in uroduction for the next three years, followed hy a very rapid reduction. They believe that the State wll be practically elimluated ats a large proiucer of narai stores withln five years. Gencmul opinim plices remaining stands at not more then 1,000 crops, incluling all second growth now merchantable.

Well-informed observers believe that Mississipll will show an increase in productlon during the next four or tive sears. The tlmber, lowever. both here and lu Louisiana and Texis, ls largely owned by lumbermen who wlll force a rapld exploitation for naval stores in order that the lumbering may not he delayed. Five thousind crops of uncupper thmber ne estimater. It is predicted that the crest of prochuction will have been passed within five years, and that this will he followed by " rapid decline. Within eight yeal's Mississippi will not be a leading State in naval-stores production.

The Industry is comparatively new in touislana. 'The timbet is largely held by lumbermen who excluded navil-stores operiltlons very generally untll four or five years ago. Nuch of the timber has been and some of it is still being cut unturpentined. The average turpentine lease on many of these large holdings does not exceed two years in lesigth. Of the 27 bilition feet of longlenf pine in louisiana the removal of 20 billion feet for lumber is preslicted dining the next 10 years. A yield of not to exceed $1: 3,500$ crops is anticipaterl. Operators familiar with the situntion agree that 10 years will mobably see the heginning of a very rapid decline In prociuction from Louisiana, and 15 years the end of the present supply.

Sawmills will probably remove 7,500 million feet of the 11 billim foet of bughlanf pinc in Toxis duriug the next 10 years, and Texas is the last stand of the turpentine industry in the South. Nival-stores productlon in Texas wili be increased rapidly as the Eastern States are exhausted, but operations will be seriously eurtailed by the desire of timber owners to exploit the stands for lumber. The nival-stores industry estimates that there are not more than 4,600 crons in Texas and predicts practical exlaustion within 10 years.

\section{METIIODS OF EXPLOITATION.}

While the rate of depletion of the supply of naval-stores timber las been greatly accelerated during the last few years by the ranid cutting of timber controlled by lumber interests, the naral-stores operators theuselyes are responsible for the fact that what was once the largest and finest naval-stores forest in existence is about to become a matter of history. The method of exploitation commonly followed during the last inundred years is crude, wasteful, destructive, and sadly shortsighted. Uncier the driving urge of nuxlmum financial returns in a mlnimum of time, regardless of after effects, turpentine orchards even to-day are operated so destructively that the trees are exhausted in from four to six years and tumed over to the sawmill man showing a loss due to turpentining of from 20 to 50 per cent.

That quick exhaustion of the turpentine productivity of the tree, and, in many cases, its early destruction, is not a necessity in the production of naval stores is slown by the French navalstores industry. For the last 80 years a system of operation has been followed in France that permits an orchard to be worked for turpentine for from 30 to 50 years, practically without loss of timber. Coupled with this admirahle system of operation is a plan of management under which a crop of new timber is continually growing into maturity to fill the gap left hy the harvesting of mature timber. As a result of such foresigit the French supply of navil stor's is increasing yearly, both in value and in amount.

Conservatlve methods of turpentining in southern pine forests lave been developed iy the Forest Sorvice and are now in commercinl use on the lyordat National Forest, and on private holdings of some of the more proguessive operators. Inertia, not financial obstacles, must be regarded as the chief reason why these conservative methols have not been more generally (mployel. They nlake entiloely possible, when combined with intelligent forest management, a pelmument as against a selfdestroying industry.

\section{DEPLETION AND PRICES.}

As In the case of lumber and newsprint, the superticial cause of abnorual prices is a combination of aimormal demand and shortage of the mamufactured product. The stocks of turpentine and rosin at the chive points of encentration were lower at the rod of the last naral-stores season than has been the case in many rars. At the sime time the demand, botil foreign and iomestic. las been stronger than at any other time during the past five yeurs. The natural result has been ke(n) competition for supplies on hand and consequent 1'lse in urice. As in the calse of lumber and other Industries, there have been increased costs. It has been dificult to secure adequate supplies of skilled labor. Credit inflation alone would have increased prices, lut the fundamental dilliculty has been the depletion of tile timber suppies from which naval stores 
can be secured and the great limitation of tise producing regions aiready discussel. The price of spirits of turpentine, which for very many years tluctuated slightly above and bclow 50 cents a gallon, had risen nearly five times to a price of $\$ 2.30$ early in 1920, and similar increases occurred in prices for various grades of rosin.

Witl a prospective reduction in domestic prociuction, the United States is facing in the near future rapidly decreasing ability to export naval-stores products, and even within a few years to meet home demands from the southern pine territory. 'There are possibilities of levelopment of the industry with other specles in the West, but under much more ariverse conditlons as to accessibility, labor, etc. The only other posstbilities are Imports or the use of substitutes.

\section{ORIGINAL AND PRESENT FORESTS OF THE UNITED STATES.}

\section{ORIGINAL FOREST AREA.}

The origfnal forest area of the country is estimated to liave been in the neighborthood of $\$ 22,000,000$ acres. (See Table 3 and tig. $3{ }^{13}$ ) In the eastern Untted States a mangificent forest

13 Various terms found in these and other accomnaning tables a d figures are used with the following meanings:

"Saw-tlmber areas" and "saw-timber atanda" are staads of sawtimber size in accordance with the prevalling logging and milling practice of the region concerved. of old-growtl timber, wonderfuily rich in variety of species and quality of material, stretched in an almost unbroken expanse from the Atlantic Ocean to the prairies. Pines and other softwoods predominated in the north and along the Atlantlc and Gulf coasts, while in the Appalachlans and on the fertile soils of the Central States and the lower Mississippi Valley

"Cordwood areas" and "cordwood stands" are stands not now of suficient size to produce saw timber under the prevalling locat logging and mitliag practice.

"Noarestocking areas" comprise lands that once supported a atand of timber, which is now gone, and which is not being renewed.

"Virgin areas" and "virgin stands" comprise stands in which there is no net growth, such growth as takea place being offset by loas from decay and other causes. This excludes certain old-growth stands, as, for example, in Callfornia, which have not been lumbered and are ordinarily reguried as "virgin" forests, but in which a net growth ts now taking place as a result of the present protection of such atauds following their opening up by fire.

"Growiag areas" and "growing stands" include all stands, irrespective of their size, in which current growth is tn exeess of curreat loss; that is, in which there is a net growth.

"Shw timber" comprises that portion of the atand on saw timber areas of sufficient size for inanufacture into lumber. Board fect eativiates of saw timber are given in terms of lumber taily ratber than $\log$ scale.

"Cordwood" comprises that portion of the staad on saw-timber areas not of sufficient size for manufacture into lumber and the entire staud on cordwood areas. It may thus include occaaional trees of kaw-timber size which occur in cordwood stands but not in sufficient quantity to be lumbered.

"Total stand" tncludes both saw tiniber and cordwood.

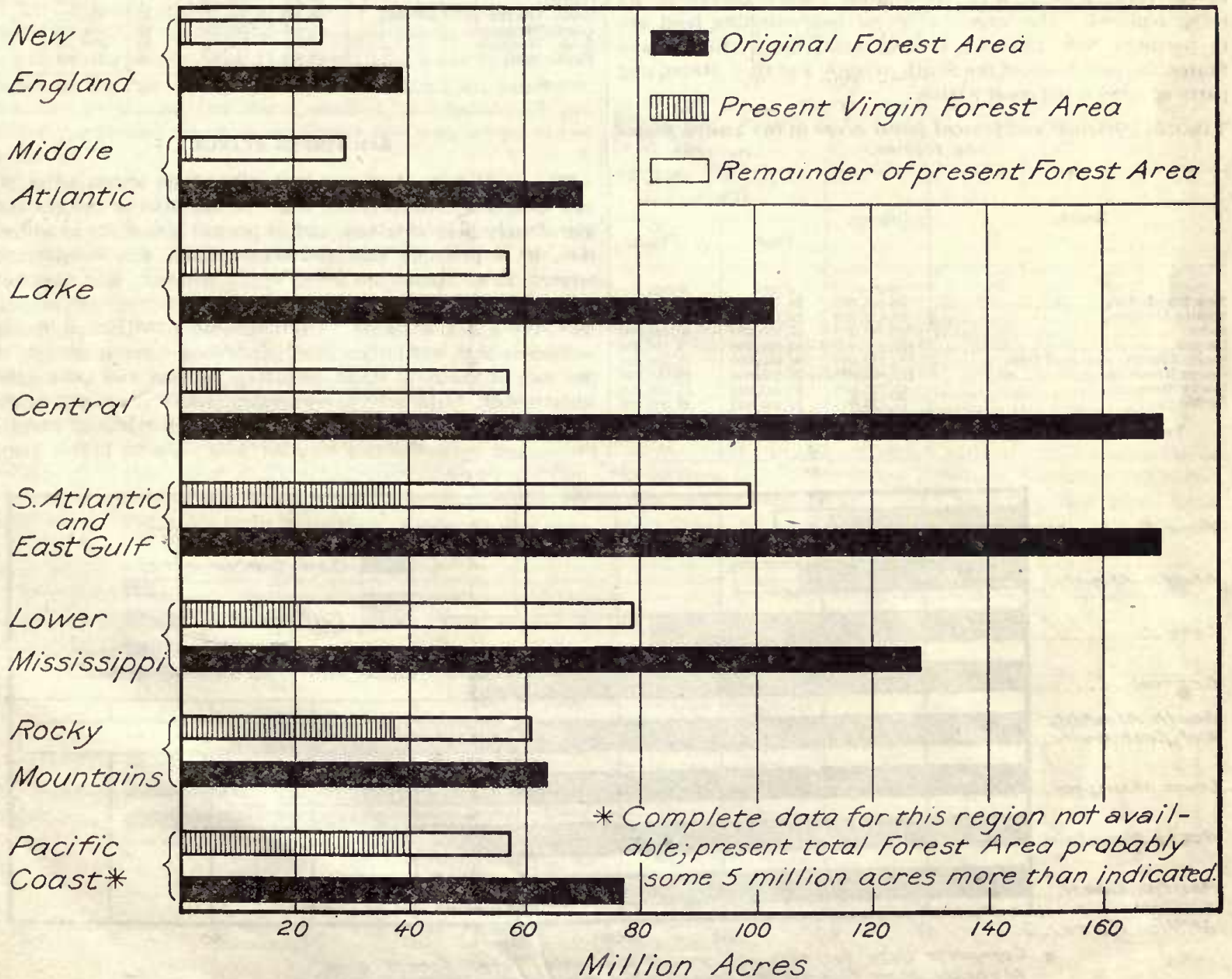

Fig. 3.- Original and present forest areas of the United States by regions. 
oak, hickory, ash, chestnut, yellow poplar, and other valuable harlwoods abounded. In the West practically all of the area not too arid to support tree growth was also covered with a forest of virgin timber interspersed with occasional patches of younger, even-aged stands, as of Douglas fir and western white pine, followlng fire. Along the Pacific coast the heavy stands of redwood, Douglas fir, western liemlock, and western red cedar formed one of the finest forests in the world.

\section{PRESENT FOREST AREA.}

To-day of the original forest area there remains but little more than half or approxlmately $463,000,000$ acres, excluding In both cases from 100 to 150 million acres of low-grade woodland and scrub. (See Table 4 and fig. 4.) Furthermore, so far lias the utilization of the orlginal forest progressed that of the total remaining area only 30 per cent, or 137 nillion acres, is virgin forest. The remainder includes 112 million acres of second-growth saw tlmber, 133 million acres of second growth below saw-tlmber size, and 81 million acres which are not restocklng. Cutting has naturally been heavlest in the most fertile and most densely populated sections of the country. Thus in the Central States the original forest has been reduced to one-thlrd of its former extent, while in the Rocky Mountains 95 per cent of it still remalns. More than half of the virgin forests of the country are in the Western States, only 15 per cent of the vlrgin forest area being included in the Northern and Central States. Over nearly a fifth of the present forest area the origlnal timber growth is not being renewed. The lr.rgest areas of nonrestocking land are in worthern New England, Pennsylvania, the northern Lake States, the pine lands of the South Atiantlc and Gulf States, and parts of the Pacific coast States.

TABLE 3.-Original and present forest areas in the United States by regions.

\begin{tabular}{|c|c|c|c|}
\hline \multirow{2}{*}{ Region. } & \multirow{2}{*}{ Original. } & \multicolumn{2}{|c|}{ Present. } \\
\hline & & Total. & Virgin. \\
\hline 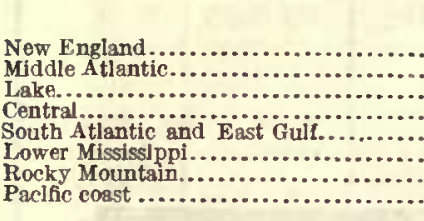 & $\begin{array}{r}\text { Acres. } \\
38,908,000 \\
69,160,000 \\
103,680,000 \\
170,560,000 \\
170,240,000 \\
128,400,000 \\
63,720,000 \\
77,120,000\end{array}$ & $\begin{array}{c}\text { A cres. } \\
24,708,000 \\
28,678,000 \\
57,100,000 \\
56,682,000 \\
99,000,000 \\
78,865,000 \\
60,842,000 \\
57,586,000\end{array}$ & $\begin{array}{r}\text { Acres. } \\
2,000,000 \\
1,896,000 \\
10,100,000 \\
7,150,000 \\
18,300,000 \\
20,835,000 \\
37,746,000 \\
39,369,000\end{array}$ \\
\hline Total....$\ldots \ldots \ldots \ldots \ldots \ldots \ldots \ldots \ldots \ldots$ & $822,238,000$ & $463,461,000$ & $137,390,000$ \\
\hline
\end{tabular}

TABLE 4.-Present forest area of the United States by regions and character of growth.

\begin{tabular}{|c|c|c|c|c|c|c|}
\hline \multirow{2}{*}{ Regton. } & \multirow{2}{*}{$\begin{array}{l}\text { 'Total } \\
\text { (thou- } \\
\text { sand } \\
\text { acres.) }\end{array}$} & \multirow{2}{*}{ Per cent. } & \multicolumn{2}{|c|}{$\begin{array}{l}\text { Saw timber } \\
\text { (thousand acres). }\end{array}$} & \multirow{2}{*}{$\begin{array}{l}\text { Cord- } \\
\text { wood } \\
\text { (thou- } \\
\text { sand } \\
\text { acres). }\end{array}$} & \multirow{2}{*}{$\begin{array}{l}\text { Non- } \\
\text { restock } \\
\text { ing } \\
\text { (thou- } \\
\text { sand } \\
\text { acres.) }\end{array}$} \\
\hline & & & Virgin. & $\begin{array}{l}\text { Grow- } \\
\text { ing. }\end{array}$ & & \\
\hline 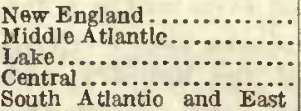 & $\begin{array}{l}24,708 \\
28,678 \\
57,100 \\
50,682\end{array}$ & $\begin{array}{r}5 \\
6 \\
12 \\
12\end{array}$ & $\begin{array}{r}2,000 \\
1,896 \\
10,100 \\
7,150\end{array}$ & $\begin{array}{r}8,761 \\
9,559 \\
13,930 \\
23,301\end{array}$ & $\begin{array}{r}8,372 \\
10,793 \\
12,570 \\
24,011\end{array}$ & $\begin{array}{r}5,575 \\
6,430 \\
20,500 \\
2,220\end{array}$ \\
\hline $\begin{array}{l}\text { Gulf } \\
\text { Lower Mijssissippi } \\
\text { Rocky Mount............ } \\
\text { Pacific coast I .................. }\end{array}$ & $\begin{array}{l}99,000 \\
78,865 \\
60,842 \\
57,586\end{array}$ & $\begin{array}{l}22 \\
17 \\
13 \\
13\end{array}$ & $\begin{array}{l}18,300 \\
20,835 \\
37,746 \\
39,369\end{array}$ & $\begin{array}{r}27,900 \\
20,200 \\
3,313 \\
5,292\end{array}$ & $\begin{array}{r}32,050 \\
24,075 \\
14,533 \\
6,425\end{array}$ & $\begin{array}{r}20,720 \\
13,755 \\
5,250 \\
6,500\end{array}$ \\
\hline Total.. & 463,461 & 100 & 137,396 & 112,256 & 132,859 & 80,950 \\
\hline
\end{tabular}

1 Complete data for this region not availabla; total forest area probably somo $5,000,000$ acres more than indleated.

TABLE 5.-Stand of saw timber in the United States by regions.

\begin{tabular}{|c|c|c|c|c|c|}
\hline \multirow{2}{*}{ Region. } & \multirow{2}{*}{$\begin{array}{c}\text { Saw-tim- } \\
\text { ber area } \\
\text { (thousand } \\
\text { acres). }\end{array}$} & \multicolumn{2}{|c|}{ Total saw timber. } & \multirow{2}{*}{$\begin{array}{l}\text { Soltwood } \\
\text { (million } \\
\text { board } \\
\text { fect). }\end{array}$} & \multirow{2}{*}{$\begin{array}{l}\text { Hard- } \\
\text { wood } \\
\text { (million } \\
\text { board } \\
\text { leet). }\end{array}$} \\
\hline & & $\begin{array}{l}\text { Million } \\
\text { board } \\
\text { feet. }\end{array}$ & $\begin{array}{l}\text { Per } \\
\text { cent. }\end{array}$ & & \\
\hline 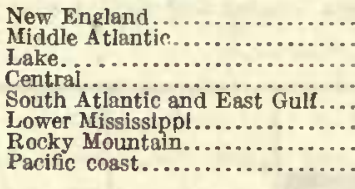 & $\begin{array}{l}10,761 \\
11,455 \\
24,030 \\
30,451 \\
46,200 \\
41,035 \\
41,059 \\
44,661 \\
\end{array}$ & $\begin{array}{r}49,799 \\
44,857 \\
110,110 \\
144,470 \\
220,577 \\
280,908 \\
223,141 \\
1,141,031 \\
\end{array}$ & \begin{tabular}{r|}
2 \\
2 \\
5 \\
7 \\
10 \\
13 \\
10 \\
51 \\
\end{tabular} & $\begin{array}{r}38,480 \\
15,353 \\
40,760 \\
11,318 \\
136,827 \\
148,308 \\
223,141 \\
1,141,031 \\
\end{array}$ & $\begin{array}{r}11,319 \\
29,504 \\
69,350 \\
133,152 \\
83,750 \\
132,600 \\
\cdots \cdots \ldots . \\
\cdots \cdots\end{array}$ \\
\hline Total. & 249,652 & $2,214,893$ & 100 & $1,755,218$ & 459,675 \\
\hline
\end{tabular}

\section{SAW-TIMBER STANDS.}

'The original stand of saw timber has been estimated at not less than 5,200 billion board feet. In the light of the cut that has already been obtalned, and of present standards of utilization, it is probable that the actual stand was considerably larger. Even taking the lower figure, however, less than half of the orlginal stand, or 2,215 billion board feet, still remains (see Table 5 and fig 5). Of this some 1,755 billion feet is softwoods and 460 bilion feet hardwoods. Approximately 70 per cent of the total stand, including the best and most accessible timber, is in private ownershlp, while about 498 billion board feet, or 22 per cent, Is included in the National Forests. States and municipalities together hold only 59 billion board

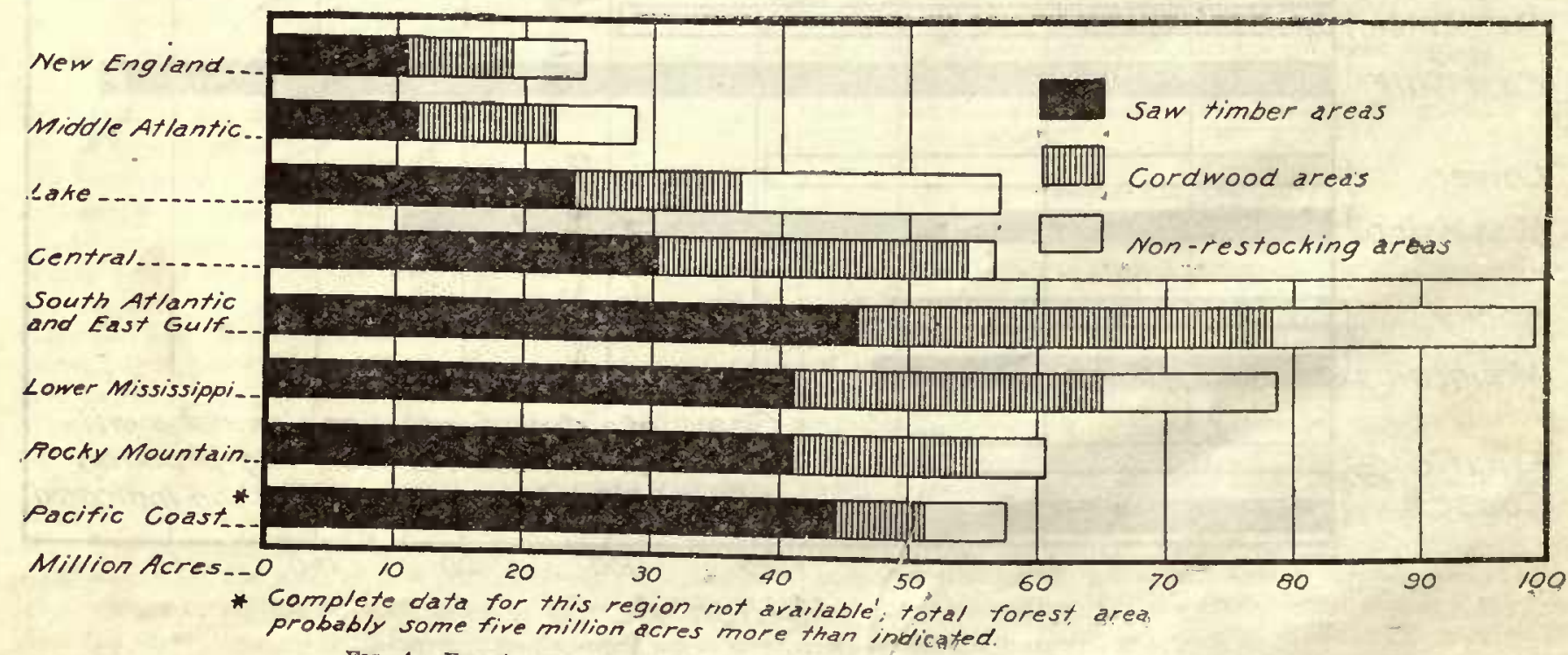

FiG. 4.-Forest areas of the United States by regions and character of growth. 


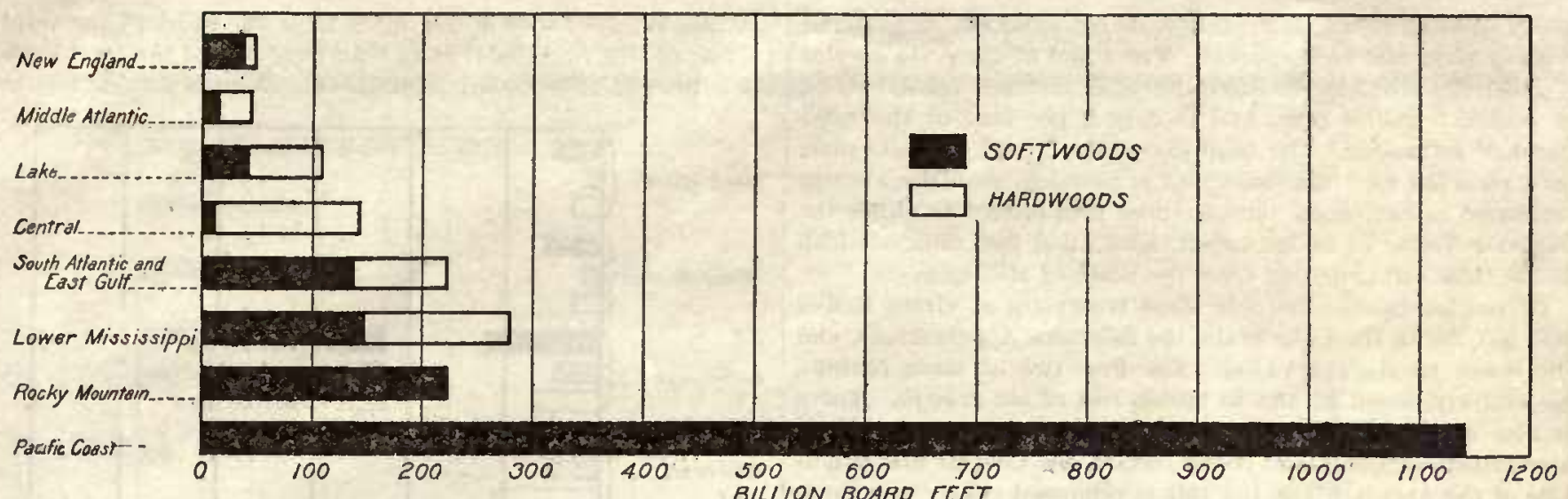

Fio. 5.-Stand of saw timber in the United States by regions.

feet, or less than 3 per cent of the total. (See Table 6 and fig 6.)

The exhaustion of the eastern forests and the steady progress of the Iumber industry toward the West is well indicated by the location of the remalning stands of sawtlmber. Thus, New England, the Middle Atlantic, Central, and Lake States, with 35 per cent of the total forest area, contaln only 349 billion hoard feet, or 16 per cent of the total; while the Pacific Coast States, witlı only 13 per cent of the forest area, contaln 1,141 billion board feet, or nearly 52 per cent of the total. (See fig 7.) Between these two extremes come the South Atlantlc, Last Gulf, and Lower Mississippi States, with 39 per cent of the forest area and 23 per cent of the sawtimber; and the Rocky Mountain States, with 13 per cent of the forest area and 10 per cent of the sawtimber. Altogether, 61 per cent of the present stand of sawtimber lies west of the Great Plains.

In otlier words, the depletion of our castern forest resources has now reached the point where the softwood stands in the Northern and Central States can no longer contribute any large proportion of the total softwood lumber consumption of the country, where the Southern States are losing the commanding position that they have held for the last 20 or 30 years, and where the one great reservoir of softwood timber stlll left Iles on the Pacific coast, chiefly in the Pacific Northwest. Douglas fir, with an estimated total stand of 596 bllion board feet, approximately 85 per cent of which is in the two States of Washington and Oregon, is the principal species in the West. (Sec Table 7 and fig. 8.) Western yellow pine is a fair second, with a total stand of 250 biliion board feet, 27 per cent of which is in the Rocky Mountains and 73 per cent on the lacific coast. Following these two species, which together com- prise nearly half of the softwood sawtimber In the entire country, come western hemlock, the true firs, and redwood, with stands of 95,91 , and 72 bllion board feet, respectively.

TABLE 6.-Ownership of forest area and stand of sawtimber in the United States by regions.

ARE A.

\begin{tabular}{|c|c|c|c|c|c|c|}
\hline \multirow{2}{*}{ Region. } & \multirow[b]{2}{*}{ Total. } & \multicolumn{2}{|c|}{ Federal. } & \multirow{2}{*}{$\begin{array}{l}\text { State. } \\
\text { and } \\
\text { munic- } \\
\text { lpal. }\end{array}$} & \multicolumn{2}{|c|}{ Private. } \\
\hline & & Total. & $\begin{array}{l}\text { National } \\
\text { Forest. }\end{array}$ & & Total. & $\begin{array}{l}\text { Farm } \\
\text { wood } \\
\text { lots. }\end{array}$ \\
\hline $\begin{array}{l}\text { Fastern United States.... } \\
\text { Rocky Mountains.......... } \\
\text { Pacific Coast............. }\end{array}$ & $\begin{array}{l}\text { Thou } \\
\text { sand } \\
\text { acres. } \\
345,033 \\
60,842 \\
57,586\end{array}$ & $\begin{array}{r}\text { Thous } \\
\text { sand } \\
\text { acres. } \\
5,578 \\
51,681 \\
30,319\end{array}$ & $\begin{array}{l}\text { Thort- } \\
\text { sand } \\
\text { actes. } \\
4,578 \\
48,281 \\
26,876\end{array}$ & $\begin{array}{l}\text { Thou- } \\
\text { sand } \\
\text { acres. } \\
4,300 \\
1,411 \\
1,475\end{array}$ & $\begin{array}{r}\text { Thor } \\
\text { sand } \\
\text { acres. } \\
335,155 \\
7,750 \\
25,792\end{array}$ & $\begin{array}{l}\text { Thou- } \\
\text { sand } \\
\text { acres. } \\
152,465 \\
\text { (1) } \\
\text { (1) }\end{array}$ \\
\hline Total............ & 463,461 & 87,578 & 79,735 & 7,186 & 368,697 & \\
\hline
\end{tabular}

BTAND.

\begin{tabular}{|c|c|c|c|c|c|c|}
\hline $\begin{array}{l}\text { Eastern United States.... } \\
\text { Rocky Mountains......... } \\
\text { Pacific Coast............. }\end{array}$ & $\begin{array}{c}\text { Mrllion } \\
\text { board } \\
\text { feet. } \\
850,721 \\
223,141 \\
1,141,031\end{array}$ & $\begin{array}{c}\text { Mrillion } \\
\text { board } \\
\text { feet. } \\
8,184 \\
157,618 \\
434,300\end{array}$ & $\begin{array}{l}\text { Million } \\
\text { board } \\
\text { feet. } \\
4,184 \\
145,449 \\
348,000\end{array}$ & $\begin{array}{c}\text { Afillion } \\
\text { board } \\
\text { feet. } \\
10,000 \\
9,791 \\
39,000\end{array}$ & $\begin{array}{l}\text { Million } \\
\text { board } \\
\text { feet. } \\
832,537 \\
55,732 \\
667,731\end{array}$ & $\begin{array}{l}\text { Million } \\
\text { board } \\
\text { feet. } \\
340,288 \\
\text { (1) } \\
\text { (1) }\end{array}$ \\
\hline Total............... & 3 & 102 & 33 & 58,791 & 1,55 & \\
\hline
\end{tabular}

1 Not indicated becausc of lack of data.

In the East the only softwood with a stand comparable to any of these is southern yellow plne, with a total of 258 billion board feet, or slightly more than western yellow pine. (See Table 7 and fig 8.) Spruce and fir come next, with a stand
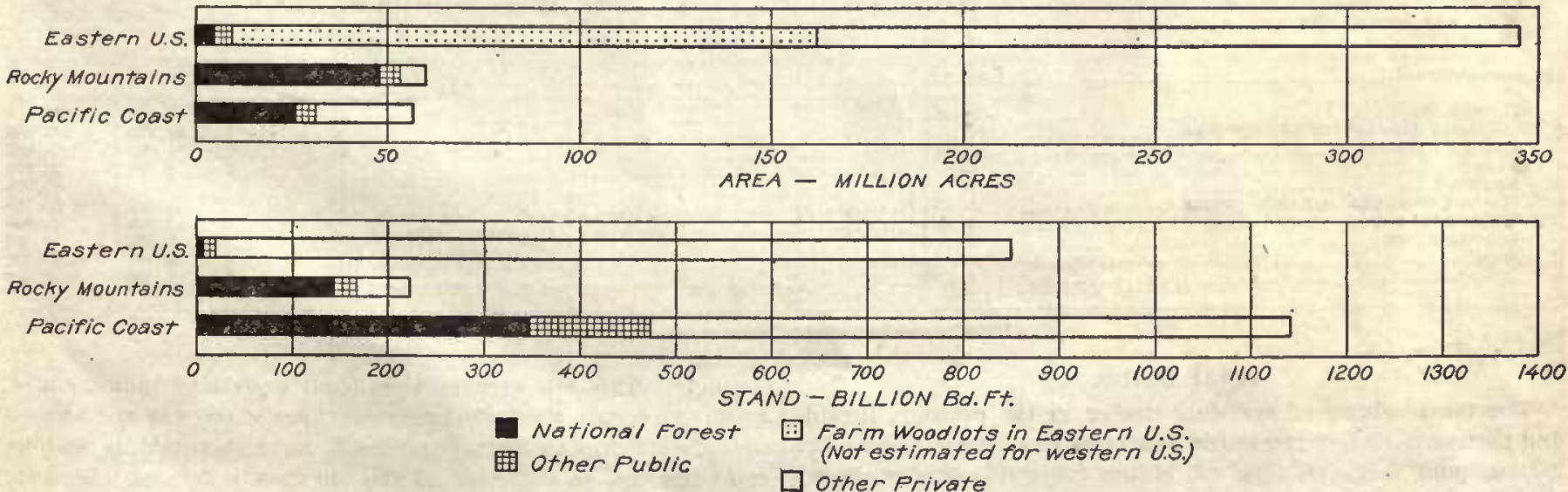

FrG. 6. - Ownershlp of forest area and stand of saw timber in the United States by regious. 
of 32 billion board feet, followed by hemlock, white and Norway pine, and bald cypress. The stand of these six specles together is considerubly less than half as much as the stand of southern yellow pine, and is only 6 per cent of the total stand of softwoods. The total saw-timber stand of white pine, once regarded as "inexlaustible," is now less than the amount estinated to liave been manufactured into lumber in elther the Siginaw Valley or at Musliegon, Mich., and less than one-fifth of the total estimated cut from the State of Mlichigan.

of the harlwoods the only large reservoirs of vlrgin timber still left are lu the Lake State, the Southern Appalachians, and the lower Mississippl Valley. The first two of these contain, respectlvely, about 32 and 53 billion feet of old growtl. There is also a considerable total stand of hardwoods, estinated at approximately 133 billion board feet, in the Central States outside of the Appalachlans, but this is composed chiefly of secondgrowtl material in wldely scattered wood lots, and can not be counted on to contribute any large proportion of high-class material to the hardwood industries. Oak ls casily the leading hardwood of the country, with a total stand of 157 billion board feet, followed by the three northern hardwoods-birch, beecl, and maple-having together 91 billlon board feet. (See Table 7 and fig. 8.) Three of the most valuable hardwoodshickory, ash, and yellow poplar-together have an estimated stand of ouly 35 billon board feet, or less than 2 per cent of the total stand. That the depletion of the hardwood supply of the country has progressed even further than that of the softwoods Is indicated by the fact that the luardwoods constitute only about 20 per cent of the saw-timber stand, as against nearly 30 per cent of the saw-tlmber cut. MLreover, the depletion is particularly marked in the case of the more valuable woods.
While the cordwood forms more than one-third of the total volume of standing timber, less than one-sixth of the total is on the cordwood areas, which average only about 850 cubic feet to

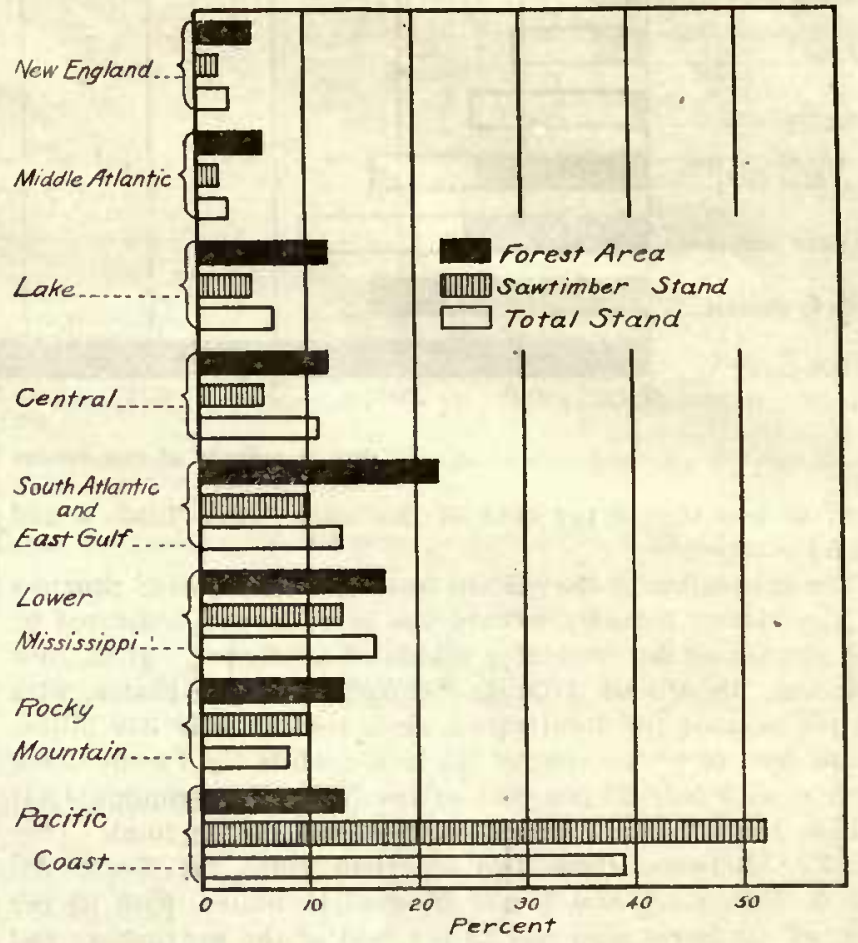

Fig. 7.- Per cent of total forest area, total saw tlmber stand, aud total stand by regions.

TABLE 7.-Stand of saw timber in the Unitcd States by species and regions.

[Quantities In million board feet, lumber tally.]

\begin{tabular}{|c|c|c|c|c|c|c|c|c|c|}
\hline 'Species. & Total. & $\begin{array}{l}\text { New } \\
\text { England. }\end{array}$ & $\begin{array}{l}\text { Middle } \\
\text { Atlantlc. }\end{array}$ & Lake. & Central. & $\begin{array}{l}\text { South } \\
\text { Atlantic } \\
\text { and East } \\
\text { Gulf, }\end{array}$ & $\begin{array}{c}\text { Lower } \\
\text { Mississippl. }\end{array}$ & $\begin{array}{c}\text { Rocky } \\
\text { Mountain. }\end{array}$ & $\begin{array}{l}\text { Pacific } \\
\text { coast. }\end{array}$ \\
\hline astern hardwoods.. & 459,675 & 11,319 & 29,504 & 69,350 & 133,152 & 83,750 & 132,600 & & \\
\hline 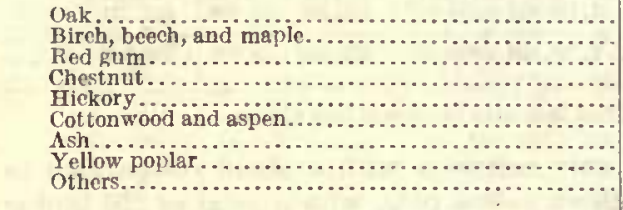 & $\begin{array}{r}157,372 \\
90,781 \\
44,222 \\
19,319 \\
15,784 \\
10,824 \\
9,988 \\
9,611 \\
101,761 \\
\end{array}$ & $\begin{array}{r}1,510 \\
8,143 \\
960 \\
40 \\
374 \\
215 \\
77 \\
\end{array}$ & $\begin{array}{r}5,500 \\
16,897 \\
176 \\
3,754 \\
412 \\
13 \\
513 \\
126 \\
2,113 \\
\end{array}$ & $\begin{array}{r}8,301 \\
36,076 \\
\cdots \\
187 \\
999 \\
1,893 \\
71,887 \\
\end{array}$ & $\begin{array}{r}64,712 \\
20,505 \\
3,728 \\
7,989 \\
6,791 \\
2,131 \\
2,929 \\
5,193 \\
19,174 \\
\end{array}$ & $\begin{array}{r}27,889 \\
4,522 \\
13,400 \\
8,616 \\
3,183 \\
1,340 \\
1,258 \\
4,020 \\
21,524 \\
\end{array}$ & $\begin{array}{r}49,460 \\
4,641 \\
26,918 \\
2,917 \\
5,17 \mathrm{i} \\
5,967 \\
3,182 \\
265 \\
36,996 \\
\end{array}$ & ...... & \\
\hline astern softwoods... & 391,046 & 38,480 & 15,353 & 40,760 & 11,318 & 136,827 & 148,308 & .............. & $\ldots$ \\
\hline 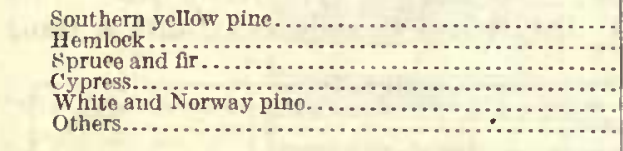 & $\begin{array}{r}257,691 \\
30,896 \\
31,572 \\
22,921 \\
23,457 \\
24,509 \\
\end{array}$ & $\begin{array}{r}1,801 \\
23,971 \\
9,816 \\
2,889 \\
\end{array}$ & $\begin{array}{r}5,036 \\
2,948 \\
4,037 \\
13,332 \\
\end{array}$ & \begin{tabular}{r}
18,301 \\
3,772 \\
\hdashline 8,000 \\
10,687 \\
\end{tabular} & $\begin{array}{r}365 \\
3,910 \\
\ldots \ldots . . . . . . \\
16,528 \\
\end{array}$ & $\begin{array}{r}121,442 \\
1,815 \\
881 \\
11,208 \\
1,089 \\
362 \\
\end{array}$ & 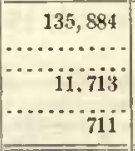 & & \\
\hline Western soltwoods...................... & $1,364,172$ & & & & …………… & ……...... & ............... & 223,141 & $1,141,031$ \\
\hline 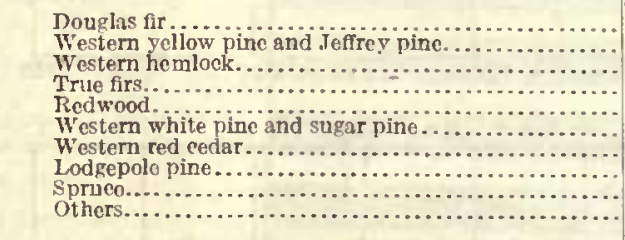 & $\begin{array}{r}595,505 \\
249,578 \\
95,092 \\
91,349 \\
72,208 \\
57,071 \\
53,348 \\
43,919 \\
39,822 \\
66,280\end{array}$ & & & & (n............ & & 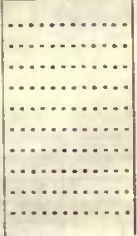 & $\begin{array}{r}39,934 \\
86,125 \\
1,092 \\
8,870 \\
18,386 \\
49,348 \\
39,353 \\
26,467 \\
21,366\end{array}$ & $\begin{array}{r}555,57 \\
183,45 \\
94,00 \\
82,47 \\
72,20 \\
38,48 \\
49,00 \\
4,56 \\
13,35 \\
44,91\end{array}$ \\
\hline
\end{tabular}

1 Ineludes small a mounts of various species of yellow pine.

TOTAL STAND.

The total volume of standing timber in the country, lncluding both saw timber and cordwood, is estlmated roughly at $\mathbf{7 4 6}$ billion cubic feet. Of thls, 485 bllion cubic feet is saw thuber and 261 bllion cublc feet cordwood, (See Tabje 8 and fig. 9.) the acre. This low average Is in itself a striking indication of failure to secure a satisfactory restocking of our cut and burned over forest lands. This fallure will have Increasingly serlous consequences, as depletion of the old-growth forests makes us more and more dependent on second-growth timber. 


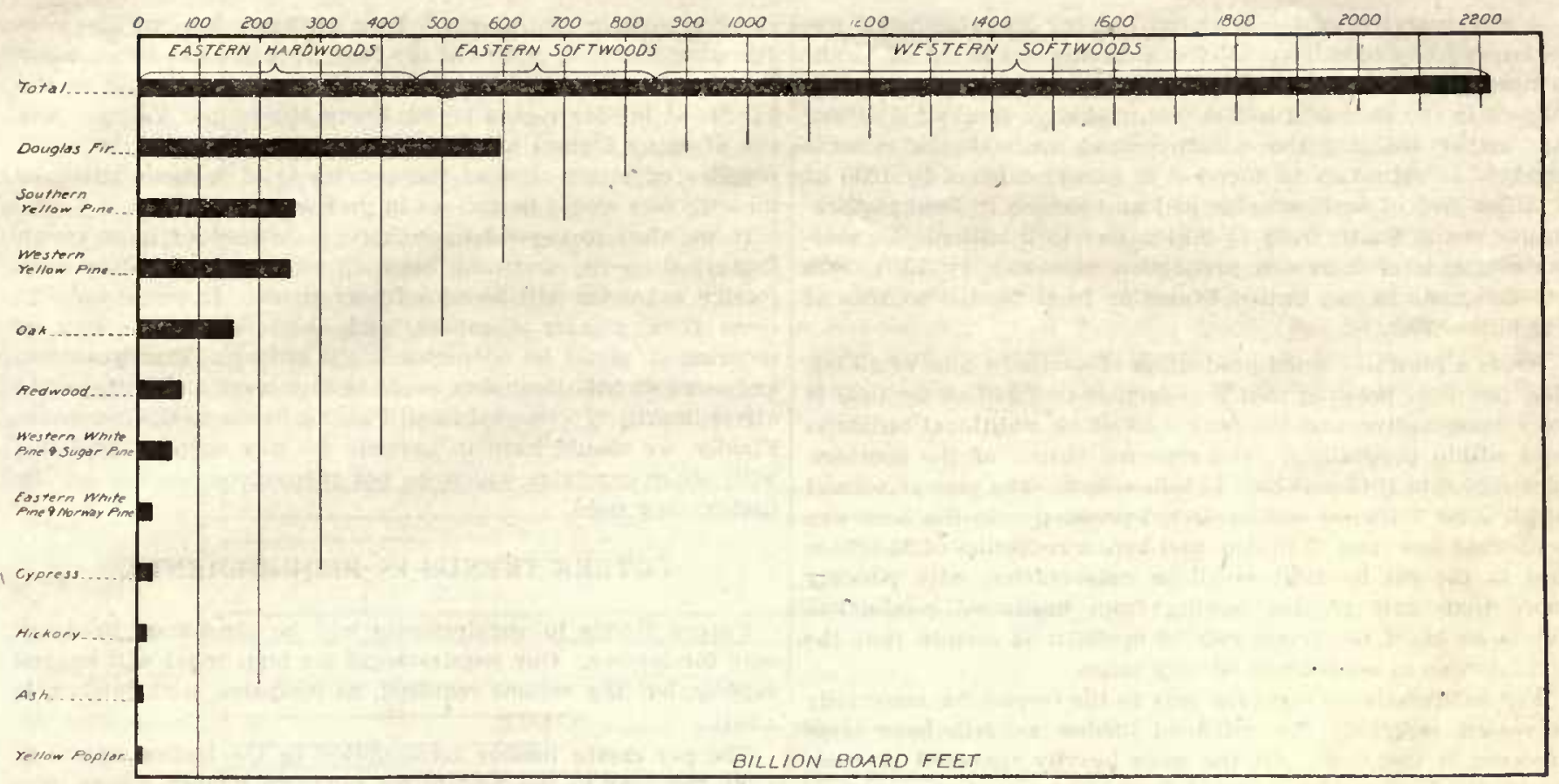

lig. 8.-Saw-timber stands of some of the more important species in the United States.

'TAв.: 8.- Total stand in cubic feet on saw-timber areas and corduood areas in the United States by regions.

\begin{tabular}{|c|c|c|c|c|}
\hline \multirow[b]{2}{*}{ Reglon. } & \multicolumn{2}{|c|}{ Total stand. } & \multicolumn{2}{|c|}{ Stand on- } \\
\hline & $\begin{array}{l}\text { Million } \\
\text { cubbic } \\
\text { feet. }\end{array}$ & Per cent. & $\begin{array}{c}\text { Saw tim. } \\
\text { ber areas } \\
\text { (million } \\
\text { cublc } \\
\text { feet). }\end{array}$ & $\begin{array}{l}\text { Cordwood } \\
\text { areas } \\
\text { (million } \\
\text { culicic } \\
\text { feet). }\end{array}$ \\
\hline 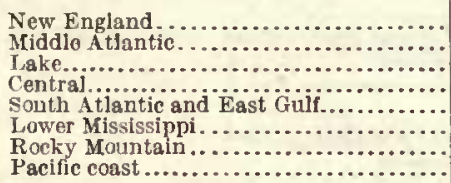 & $\begin{array}{r}20,850 \\
24,897 \\
50,584 \\
85,118 \\
96,158 \\
118,364 \\
61,893 \\
287,724\end{array}$ & $\begin{array}{r}3 \\
3 \\
7 \\
11 \\
13 \\
16 \\
8 \\
39\end{array}$ & $\begin{array}{r}15,492 \\
17,126 \\
41,534 \\
61,319 \\
73,060 \\
95,252 \\
53,755 \\
274,874\end{array}$ & $\begin{array}{r}5,358 \\
7,771 \\
9,050 \\
23,799 \\
23,098 \\
23,112 \\
8,138 \\
12,850\end{array}$ \\
\hline Total... & 745,588 & 100 & 632,412 & 113,176 \\
\hline
\end{tabular}

\section{LOCATION OF REQUIREMENTS WITH REFERENCE TO PRODUCTION AND SUPPLIES.}

In the eomparatlvely near future all of our eastern timber reglous whieh do not already import more lumber than they export will begin to do so.

The southern pine region as already shown is stlll a large exporter, but within 10 years produetion promises to be little, if any, In excess of local requirements. In New England total eonsumption probably passed tothl output between 1880 and 1890, and within a few years this section wlll meet half of its total requirements from outside sources. New York has not produced lumber in excess of its own needs slnce a few years before the Civll War. The Pittsburgh district alone probably uses more lumber than is now cut in the entire State of Pennsylvania, and the State ceased to be an Important exporter shortly after 1890 . The Iake States as a whole still produce more lumber than they consume, but already Michigan and Wisconsin are net importers and it is pratically certain that the Lake States as a whole wlil consume more lumber than they produce within 10 years. Olio, Indiana, and Illinois slnee records have been kejt have always lmported nore lumber than they produced. West Virglnla, Kentucky, and Tennessee were probably net exporters for abont 20 years after 1890 , but if thrown together with Obio, Indiana, and Illinols, they form a group which has always used nore lumber than it produced.

No lumber-producing region in the East can with certainty be counted on to produce more lumber in 1930 than it will consume. The southern Mississippi Valley and possibly the southem Appalachian Mountains may produce more hardwood lumber than is needed loeally, but they also are likely to be net $1 \mathrm{~m}$. porter's if all classes of lumber are considered.

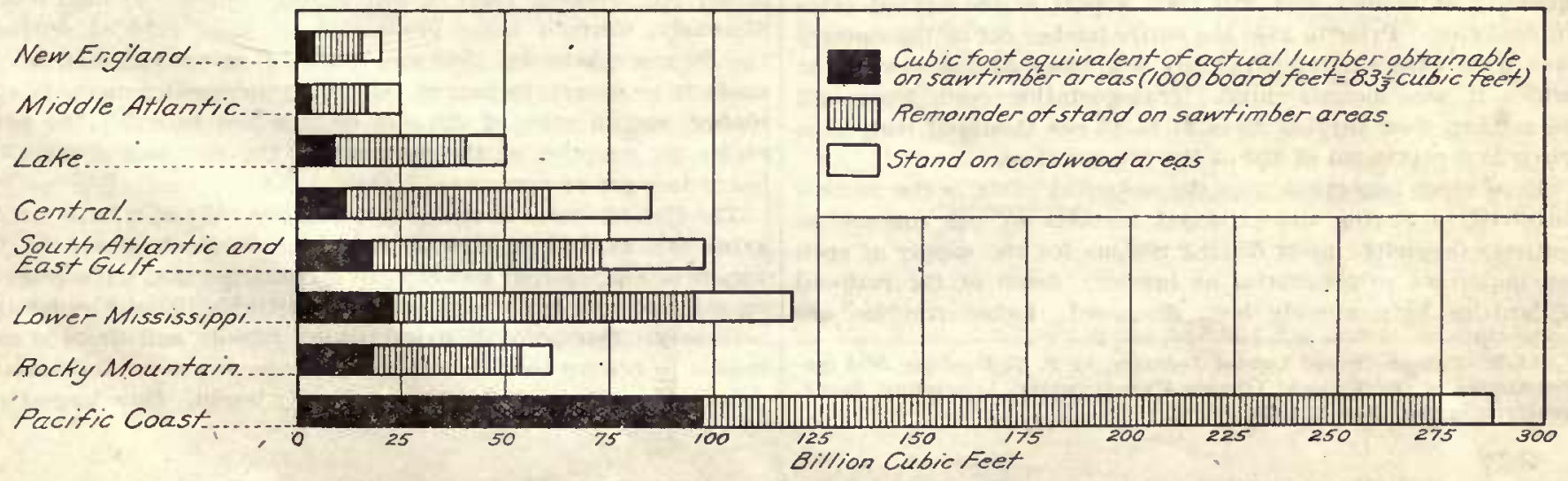

1.1c. 9.-Total stand in cubic fect on saw-timber areas and cordwood areas in the United States hy regions. 
A representatlve of the National Lumber Manufacturers' Association ${ }^{14}$ has recently predicted a decline in the cut of southern plne of 7 billion feet by 1930, and a further decline in other regions in the East of 2 billion feet, making a total of 9 billion. As further reducing the eastern output available for general markets he estimates an increase in cxport demand by 1930 of 1 billion feet of southern pine and an increase in local requlrements In the South from $7 \frac{1}{2}$ billion feet to 9 billion. He estlmates the total increased production necessary by $\mathbf{1 9 3 0}$ from other regions in the United States or from foreign sources at $11 \frac{1}{3}$ billion feet.

From a prewar normal production of southern pine of 15 billion feet it is believed that a reduction to 9 billion by 1930 is very conservative, and the falling off of an additional billion is well within possibilltes. The reported output of the sonthern pine region in 1918 was only 11 billion feet. The prewar normal of all other softwood and hardwood production in the East was somewliat less than 15 billion, and here a reduction of $3 \frac{1}{2}$ billion feet ln the cut by 1930 would be conservative, with possibly more than half of this coming from hardwood production. While no exact prediction can be made, it is certain that the total decline in output will be very large.

Fol hardwoods we can turn only to the tropics for materially increased supplies. For softwood lumber we still have large rescrves in the West. Of the more heavily timbered Western States the least can be expected from Montana. Inereased cuts are predicted from Idaho, California, and Washington by men in the industry most familiar with the sltuation. The main increases, however, will have to come from Oregon. So far as domestic production is concerned, the entire United States will tlierefole be chiefly dependent for lumber in excess of local production upon three or four States in the far West.

The part of the lumber traffic from the West which is not handled by ocean shipments via the Panama Canal must move east over the main lines of the transcontinental railroad systems. Even under conditions of the past 10 years there has been a constant complaint from lumber manufacturers of inability to secure cars. The sltuation has been at its worst durlng the past year. Shipments for a very considerable part of the western traffic during 1919 averaged slightly more than 26,000 feet to the car. At this rate every additional billion feet of lumber shipped east would mean 40,000 additional carloads. Five billion feet would make 200,000 carloads. In addition to the difficulty in building and maintainlng additional equipment are the physical difficulties involved in moving such vast amounts of freight.

Assuming an average freight rate of $\$ 15$ per thousand on shlpments of lumber from the West and increased demands upon that region of 10 billion feet in 1930, the annual freiglit bill for moving this timber to the eastern and middle western markets would be $\$ 150,000,000$. This is about one-half more than the present average transportation cost for the same quantity of lumber, and will form a part of the annual price of depletion. Prior to $\mathbf{1 8 4 0}$ the entire lumber cut of the country was used withln a comparatively few miles of the sawmill at which it was manufactured. Transportation costs from mill to market, then varying from $\$ 1$ to $\$ 3$ per thousand feet, have risen to a maximum of $\$ 20$ at the present time.

Even more important than the mounting costs ls the menace involved in having the principal markets of the country so entirely dependent upon distant reglons for the supply of such an important raw materlal as lumber. Some of the rallroad difficulties have already been discussed. Labor troubles are

\footnotetext{
14 Iife of the Softwood Lumber Industry, by F. V. Dunham, field representative of the National Lumber Manufacturers' Association, Southern Lumberman, May 8, 1920.
}

another possible contingency. How seriously bad weather conditions of a season or two at the logging camps can affect many -industries and classes of consumers is now illustrated in the hardwood lumber region of the lower Mississippi Valley. Any one of many factors nay disorganize the lumber markets and supplies of nine-tenths of the country, and a combination of these factors would be serlous in proportion.

If we elect to depend upon imports instead of home-grown timber, there is, first, the question of whether timber from foreign countries will be actually available. It would have to come from greater distances, and obstacles in the way of securing it would be correspondingly greater. Transportation and other distribution costs would be increased, and higher costs are ordinarlly represented in still higher prices to the consumer. Finally, we should have to compete for any supplies available with other countries which do not themselves produce all the timber they need.

\section{FUTURE TRENDS IN REQUIREMENTS.}

Future trends in requirements will be considered in detail only for lumber. Our requlrements for pulp wood will expand rapidly, but the volume required, as compared with lumber, is small.

The per capita lumber consumption in the United States in 1850 , the year of the first fairly complete lumber census, was only 230 board feet, with a lumber production of 5.4 billion board feet and a population of $23,192,000$. It then increased steadily until it reached its crest of 515 board feet in 1906 , with a total Iumber cut of approxlmately 45 billion feet. From 1906 to 1913 the per capita consumption declined to 430 board feet. The war curtailed production to 32 billion feet in 1918 , or 300 board feet per caplta, of which part was for war pur-

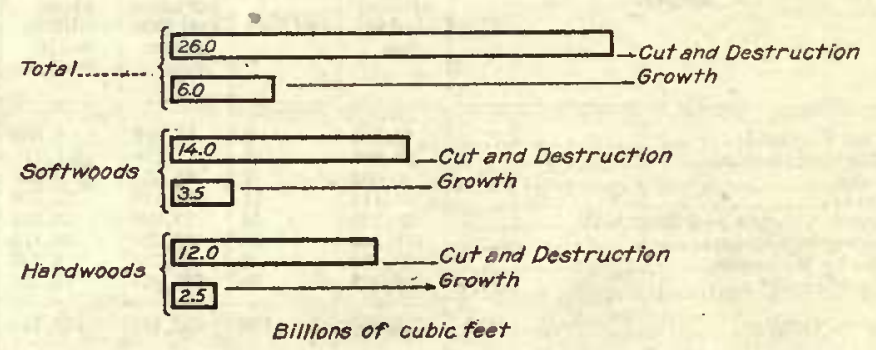

Fia. 10.-Reiation between forest depietion and forest growth.

poses. This restricted use resulted in the abnormal demands and unprecedented prices of the past year.

The experience of industrial European countries gives some Indication of what American future requilements for lumber will be. In England, for example, during the 60 years from 1851 to 1911 the consumption of lumber increased from 40 board feet to 120 board feet per caplta, although 95 per cent of her requirements must be met through imports at high cost. Similarly, German home production at least doubled during the 60 years betwcen 1840 and 1900 . Industrial development made it necessary to import constantly increasing amounts of timber, and in spite of the cost of imported material, the per capita consumption at the outbreak of the war was about 150 board feet per annum.

The United States is still a new country. We still liave large areas of undeveloped agricultural lancl. In mucl of our territory first construction was of such a character that replacement on a larger and better scale will be destrable if not absolutely necessary. Our population is growing rapidly and there is no reason to believe that it will not contlnue to grow. Industrial development in many sections has hardly begun. How large the 
per capita consumptlon In industrlal centers is inay be judged from the fact that in St. Iouis the per caplta consumption is over four times that for the entlre country, in l'ltsburgl three times, and In Chicago at least double.

Even with lare allowances for the substlution of other materials for timber, it sceuns hardly possible that our annual denand for lumber for years to come will fall below 35 billion feet. This is 5 bililon less than the prewar average of approxlmately 40 bilition board feet. Even thls wlll require a gradually reduced per capita consumption as population increases. For many years we shall find ourselres unable to satisfy our requirements with anything approaching the per caplta consumption of either England or Germany. It follows that any future lumber production falling below approximately 35 billion feet, cay. The other 16 billon board feet comes from growlng stands, but their growth is only 10 blllion feet annually. In other words, besldes the very heavy drain on our rapidly diminishing supply of virgin tlmber, we are cutting even the second growth saw tlmber more than one and one-half times as fast as it is belng replaced.

Comparison of the rates of depletion and of growth of all timber below saw-timber size discloses that even this material is being used up three and one-half tlmes as fast as it grows, or at the rate of about 14 billion cuble feet, as compared with a growth of only about 4 billion feet. (See fig. 12.) If this serlous situation continnes it will reduce very materially the volume of the material which can reach saw-timber size in the future.

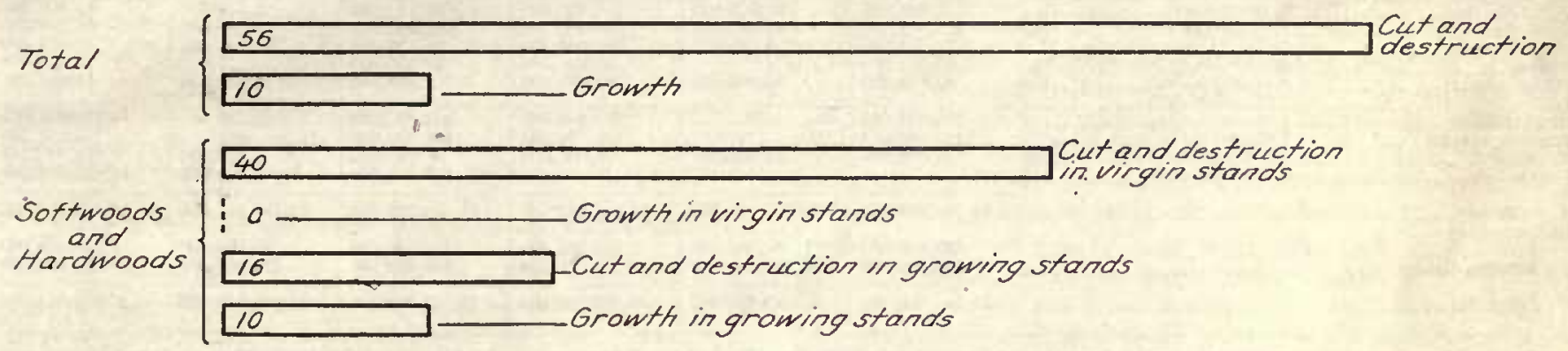

Softwoods

$\left\{\begin{array}{l}32 \\ 0 \quad \text { Growth in virgin stands } \\ \text { Cun virgin stands } \\ 8 \text { Gut and destruction in growing stands } \\ 6 \text { Growth in growing stands }\end{array}\right.$

Hardwoods $\begin{cases}8 & \text { Cut and destruction in virgin stands } \\ 10 & \text { Growth in virgin stands } \\ 8 & \text { Gut and destruction in growing stands } \\ 4 & \text { Growth in growing stands }\end{cases}$

Billions of board feet

Fic. 11.-Relation between forest depletlon and growth of saw timber.

unless we can make up the dlfference by imports, will result in lardshlp to many classes of consumers and to many industrles, like that experienced within the last year. Any such reducel consumption will unquestionably be the result of economlc pressure from lumber shortages and high prices rather than of economic convenience. We have our warning in the present situation.

\section{DEPLETION AND GROWTH.}

\section{PRESENT DEPLETION AND GROWTH.}

The standlng timber in the United States ls being cut and destroyed at the rate of 26 blllion cubic feet per year, or more than four times as fast as new timber is growing. (See Tables 9 and 10 and fig. 10.) That of saw-timber slze is being cut for lumber and other uses and destroyed by fire, disease, and insects at the rate of 56 billion. board feet per year, more than five and one-half times the growth of such material. (See fig. 11.)

Such data as are available (see Table 9) indicate that about 40 billion board feet is taken each year from our remalnlng virgln stands, in which there is no net growth in excess of de-
This depletlon of small timber is proceeding at an especially rapid rate in the case of hardwoods, perhaps in part because the supply of larger timber has been practlcally exhausted in several regions. The cut of cordwood material in hardwoods almounts to $8 \frac{1}{2}$ billion cubic feet, five tlmes the growth.

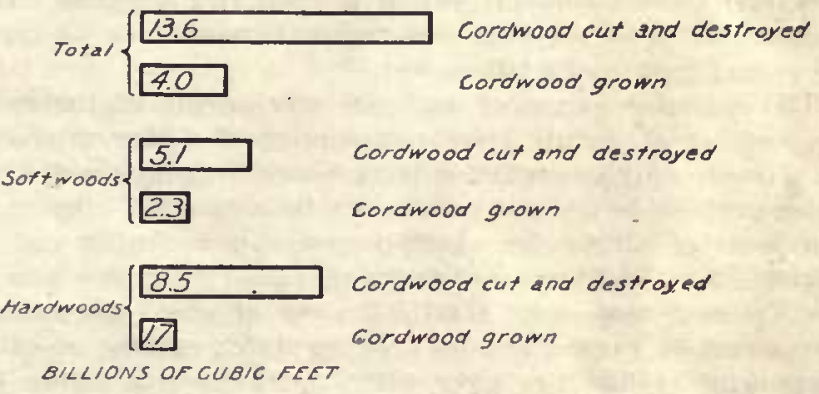

Fra, 12.-Réation between forest depletion and growth of cordwood. 
TABLE 9.-Timber removed each year from the forests of the United States.

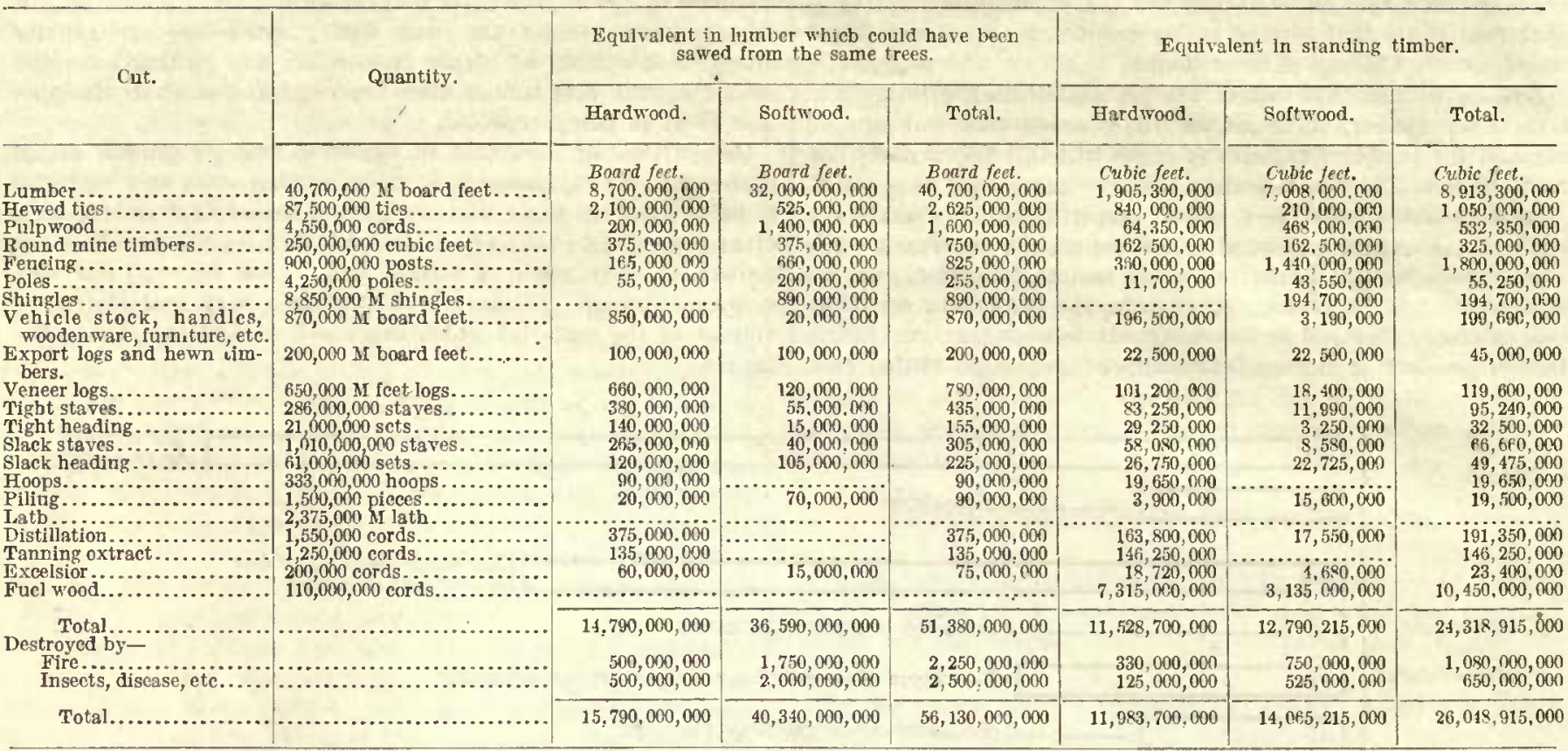

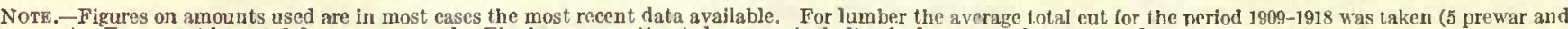
5 war years). For export logs 1913 figures were used. Fire loss is an estimated average including bad years, such as 1910 and 1919 .

TABLE 10.-Annual growth of saw timber and cordwood in the United States, by regions.

\begin{tabular}{|c|c|c|c|c|c|c|}
\hline \multirow{3}{*}{ Region. } & \multirow{3}{*}{$\begin{array}{l}\text { Growing } \\
\text { area. }\end{array}$} & \multicolumn{5}{|c|}{ Annual growth. } \\
\hline & & \multirow{2}{*}{ Total. } & \multirow{2}{*}{$\begin{array}{l}\text { Per } \\
\text { rent. }\end{array}$} & \multicolumn{2}{|c|}{ Saw timber. } & \multirow{2}{*}{ Cordwood. } \\
\hline & & & & Bosrd feet. & $\begin{array}{l}\text { Per } \\
\text { cent. }\end{array}$ & \\
\hline $\begin{array}{l}\text { New England.... } \\
\text { Mlddle Atlantic.. } \\
\text { Lake............ } \\
\text { Centra.............. } \\
\text { South Atia nitic }\end{array}$ & $\begin{array}{c}\text { A cres. } \\
17,133,000 \\
20,352,000 \\
26,500,000 \\
47,312,000\end{array}$ & $\begin{array}{c}\text { Cubic feet. } \\
474,000,000 \\
499,000,000 \\
468,000,000 \\
906,000,000\end{array}$ & $\begin{array}{r}8 \\
8 \\
9 \\
15\end{array}$ & $\begin{array}{r}609,000,000 \\
714,000,000 \\
988,000,000 \\
1,458,000,000\end{array}$ & $\begin{array}{l}28 \\
31 \\
46 \\
35\end{array}$ & $\begin{array}{l}\text { Cubic fee. } \\
341,000,000 \\
342,000,000 \\
251,000,000 \\
587,000,000\end{array}$ \\
\hline $\begin{array}{l}\text { and East Gulf. } \\
\text { Lower Mississtppi } \\
\text { Rock M Mountain } \\
\text { Pacific Coast...... }\end{array}$ & $\begin{array}{l}59,980,000 \\
44,275,000 \\
17,846,000 \\
11,717,000\end{array}$ & $\begin{array}{l}1,594,000,000 \\
983,000,000 \\
365,000,000 \\
706,000,000\end{array}$ & $\begin{array}{r}26 \\
16 \\
6 \\
12\end{array}$ & $\begin{array}{r}2,428,000,000 \\
1,752,000,000 \\
461,000,000 \\
1,262,000,000\end{array}$ & $\begin{array}{r}33 \\
-39 \\
28 \\
39\end{array}$ & $\begin{array}{r}1,062,000,000 \\
600,000,000 \\
264,000,000 \\
430,000,000\end{array}$ \\
\hline Total... ... & $245,115,000$ & $5,995,000,000$ & 100 & $9,672,000,000$ & 35 & $3,877,000,000$ \\
\hline
\end{tabular}

With softwoods the depletion of saw timber is more striking, although the cut of small timber ls also considerably in excess of its growth. Nearly three-fourths, or 40 billion board feet of the saw tlmber used and destroyed, conses from softwood for. ests, and about 32 billion feet of it from virgin stands. The total depletion of softwood saw timber is nore than $6 \frac{1}{2}$ times its annual growth of 6 billion feet.

The enormous excess of depletion over growth of tlmber is not because of nnduly large consunption of timber products. It is due in part to needlessly large losses from fires and other causes, which to a great extent can be controlled. But it is due most of all to the wasteful methocks of cutting and to neglect of cut aud burned over forest lauch. There are now in the Unlted States about $81,000,000$ acres of waste forest land, devastated by cutting and by fires, on which nothing of value is growing or likely to grow without a huge expencliture for reforestation. This area is equal to the combined areas of the forest lands of France, Germany, Pelgium, Holland, Denmark, Switzerland, Spain, anl Portugal. Besides the waste land there are in the United States approximately $245,000,000$ acres bearing second-growth forest. In a large part of this forest, wasteful cutting or excessive' grazing lave reduced production to a mere fraction of wlat it might be with proper handling. To convert sucl stands into valuable producing forests will in many cases involve expenditures as great as though the lands were devastated.

The area of-devastated and partlally devastated land is rapidly lncreasing. Timberlands are cut over mucb more closely now than formerly, with the result that after fires have killed out most of the young growth on loggell-off lands there is little or no chance for reproduction to start. At least $5,500,000$ acres of merchantable timber are cut over every year. Part of it restocks and part does not. During the period from 1915 to 1918 an average of $9,400,000$ acres of forest land was burved over each year, and in years like 1910 and 1919 the acreage was considerably larger. Some of this land restocks and some becomes waste, whlle the productivity of practically all is reduced.

\section{POSSIBLE GROWTH.}

If all of this land had been cut over in the first place, with due regard to securing a future stand, and had been protected from fires or excessive grazing after cutting, it would now be producing timber at least three times as fast as at present. Judging from the experience of other countries and from results obtained where forests have been carefully treated in our own country, it is believed entirely conservative to assume that the 326 million acres could produce at an average rate of 60 cubic feet of wood per acre per annum, or, in terms of saw timber, 150 board feet per annum. This would mean a total anmual growth on the present area of cut-over forest land, iucluding that now devastated, of $19 \frac{1}{2}$ billion cubic feet of wood, Including 49 billion board feet of saw timber. At the same rate of production for the remaining 137 million acres of virgin forest in which there is now no net increment, our total commercial forest area is capable of producing annually, after the virgin timber has been cut off, at least $27 \frac{3}{4}$ billion cubic feet of wood, including 70 billion board feet of saw timber. This exceeds our present rate of use and destruction. With a reasonable per capita consumption, it would be able to weet indefinitely the needs of our growing population for woon and other forest products. 


\section{FOREST DEPLETION AND LUMBER PRICES.}

The conrse of lumber prices in the Uniter States has been very miterially affected by the successlve depletlon of ofd and development of new fields of tumber jroduction. As one great forest region after anolluer has been opened up two counternethig hufluches hatre been brought to bear on prices. One of these las been interegional conpetition. Exploitation bas bexun in new regions well in advance of exhaustion of the oldor sources of sulpily. The result his been to hold in check the graluat rise in price which would normally take place as competitlon relaxed with the diminulion of supplies in the older resions and ats exploitation advanced from the most accessible and easily logged timber to that involviug higher costs of production and transportation. On the other hand the cutting out of the older regions and the resulting necessity of drawIng lumber supplies from more distant fields has meant, of course, the periodic addition of new transportation costs.

\section{PRICE CHANGES AND REGIONAL DEPLETION.}

Thus prices have tended to rise at a step from one level to another and then to hold pretty well on this tevel for a term of years ratice than to follow an ascending curve. This is most mill'ked with the softwonds.

\section{EASTERN SOFTWOOD MARKETS.}

Talble 11 shows the lumber prices in eustern markets at five-year Intervals from 1840 to 1910 and yearly from 1910 to 1920. The prices are computer throughout on a gold standard to eliminate the distortion resulting from depreciated values iuring the paper-enrrency period.

TABLE 11.-Trend of average wholesale values (eastern markets.)

\begin{tabular}{|c|c|c|c|c|}
\hline \multirow{2}{*}{ Year. } & \multicolumn{2}{|c|}{$\begin{array}{l}\text { Softwoods, 1-ineh } \\
\text { stock. }\end{array}$} & \multicolumn{2}{|c|}{$\begin{array}{l}\text { Hardwoods, 1-inch } \\
\text { stock. }\end{array}$} \\
\hline & $\begin{array}{c}\text { First } \\
\text { quality } \\
\text { per M feet. }\end{array}$ & $\begin{array}{c}\text { A verage } \\
\text { quality } \\
\text { per M feet. }\end{array}$ & $\begin{array}{c}\text { First } \\
\text { quality } \\
\text { per M feet. }\end{array}$ & $\begin{array}{l}\text { Average } \\
\text { quality } \\
\text { per M foet. }\end{array}$ \\
\hline 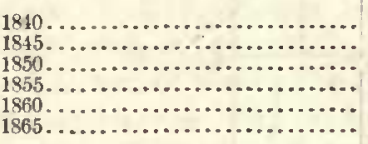 & \begin{tabular}{r|}
$\$ 20.91$ \\
21.46 \\
24.35 \\
26.15 \\
24.45 \\
20.43
\end{tabular} & \begin{tabular}{r|}
$\$ 10.50$ \\
10.50 \\
10.50 \\
11.00 \\
11.50 \\
9.25
\end{tabular} & $\begin{array}{r}\$ 1.03 \\
12.24 \\
13.57\end{array}$ & $\begin{array}{l}\ldots \ldots \ldots \ldots \\
\ldots \ldots \ldots \ldots \ldots \\
\ldots \ldots \ldots \ldots \ldots \\
\ldots \ldots \ldots \ldots \ldots \\
\ldots \ldots \ldots \ldots \ldots\end{array}$ \\
\hline 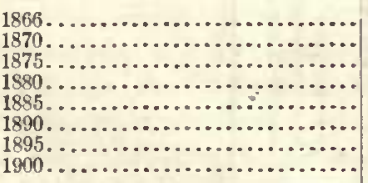 & $\begin{array}{l}41.32 \\
37.70 \\
39.93 \\
38.41 \\
41.51 \\
34.48 \\
29.39 \\
34.06\end{array}$ & $\begin{array}{l}14.28 \\
14.01 \\
13.33 \\
14.00 \\
17.00 \\
16.40 \\
16.55 \\
21.50\end{array}$ & $\begin{array}{l}20.94 \\
24.89 \\
27.64 \\
31.62 \\
31.46 \\
33.07 \\
34.52 \\
39.29\end{array}$ & 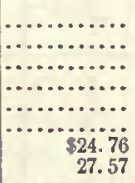 \\
\hline 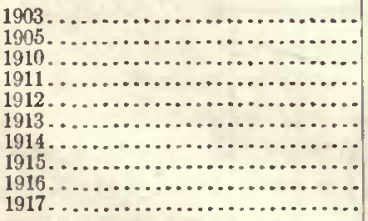 & $\begin{array}{l}41.93 \\
42.59 \\
43.50 \\
45.06 \\
44.53 \\
44.92 \\
42.76 \\
41.89 \\
41.53 \\
42.60\end{array}$ & $\begin{array}{l}21.20 \\
22.06 \\
24.60 \\
24.52 \\
25.29 \\
27.88 \\
25.19 \\
24.68 \\
26.86 \\
29.09\end{array}$ & $\begin{array}{l}46.43 \\
41.97 \\
49.17 \\
50.59 \\
51.44 \\
53.99 \\
54.94 \\
52.94 \\
54.59 \\
56.00\end{array}$ & $\begin{array}{l}33.72 \\
31.80 \\
35.61 \\
35.45 \\
35.73 \\
38.61 \\
38.23 \\
35.49 \\
37.64 \\
38.92\end{array}$ \\
\hline $\begin{array}{l}1918 \ldots \ldots \ldots \ldots \ldots \ldots \ldots \ldots \ldots \ldots \\
1919 \ldots \ldots \ldots \ldots \\
1920 \ldots \ldots \ldots \ldots \ldots\end{array}$ & $\begin{array}{r}51.45 \\
61.58 \\
131.55\end{array}$ & $\begin{array}{l}39.90 \\
44.42 \\
73.26\end{array}$ & $\begin{array}{r}66.65 \\
72.62 \\
1178.82\end{array}$ & $\begin{array}{r}46.42 \\
55.54 \\
1123.80\end{array}$ \\
\hline
\end{tabular}

1 Figures apply to first three months.

While a great variety of factors have influenced lumber prices, a succession of price levels with suclden transitions corresponding to important shiftings of the lield of suppiy may be readity discerneri. There has been nuch prlce fluctuation in the soft- woods, but in every instance price declines have ultimately been regilined and new levels have been estabtished. The underlylng cuuse has been the widening distance between the sawmili and the consumer of its proluct.

The trend of tumber prices in eastern markets since 1840 is further illustrated in figure 13, which presents average wholesale values of upper grades of softwoods and hardwoods separately In relation to the average price trend of all commolities. Thiese values are expressed in percentages, with 1860 prices as the index basis, and on a gold standard throughout. IIardwood prices will be discussed in a subsequent section.

Between 1840 and 1860 atverage prices of softwood lumber in the eastern markets followed quite closely the average price of all commoditles. The lumber was principally white pine from New York, New England, and Pennsylvania. The average value of upper grades in the wholesale trade fluctuated between $\$ 20$ and $\$ 30$, centering about $\$ 25$ per thousand feet, while materlat of average quality sold fairly uniformly at $\$ 10$ to $\$ 11$. Transportation costs were about $\$ 1$ per thousand. About 1850 white pine from the Lake States began to filter through to the Atlantic seaboard, and by 1860 Chicago had repiaced $\mathrm{Al}$ bitny, N. Y., as the lending fumber distributing center in the world. The increase in volume of the more distant I ake States timber entering the eastern market from tlien on was accompanted by a price alvince in upper grades from $\$ 24$ in 1852 to $\$ 30$ in 1858 , and may be accounted for by a growing shortage of eastern white pine.

The Civil War greatly affected the price of lumber, in common wlth that of other commodities, through inflation; but calculated on a gold-standard basis softwood values did not increase materially untll after 1865. But between 1865 and 1870 softwoods parted company witlı general commodity values, and with the exception of one brief period have so remained untit the present time.

'The softwoods reached their new price level in 1866. From that year onward lumber prices, except as indicated, remained well above the average for all commodities.

'I'lie general level of softwood uppers from 1866 to 1890 was between $\$ 34$ and $\$ 40$ per thousand, and that of the lower grades between $\$ 14$ and $\$ 18$, an increase over the prewar levels of $\$ 10$ to $\$ 15$ and of $\$ 4$ to $\$ \$$ per thousand, respectively. This was the period during which Lake States white plne was entering the eastern market in increasing volume, at increased transportation costs of about $\$ 5$ per thousand. Undoubtedly the increasing absolption of timber from the Lake States by the MIddle Western States, whose development was proceeding rapidly, and the growing scarcity of local timber also exerted a lifting influence on softwood prices. Large rafts of lumber were passing down the Mississippi River to Memphis, Vicksburg, and even New Orlenns.

The financial depression which began in 1873 caused a temporary decline of lumber prices in common with all commodities. Following 1879 softwond lumber prices advanced steadily until 1883, when the upward trend was checked by an fincreasing inflow to the large castern markets of yellow pine from the forests of Virginia, North Carolina, South Carolina, and Georgia, and the rapidly increasing cut in the Lake States. Supplies were brought to New York, Pliludelphla, Boston, Baltimore, and other eastern centers by water transportation.

During the year 1857, for example, over 200 million feet of southern pine was recelved at New York, an increase of nearty 30 per cent over 1886 . Only a few years before there was but 
TIMBER DEPLETION, PRICES, EXPORTS, AND OWNERSHIP.

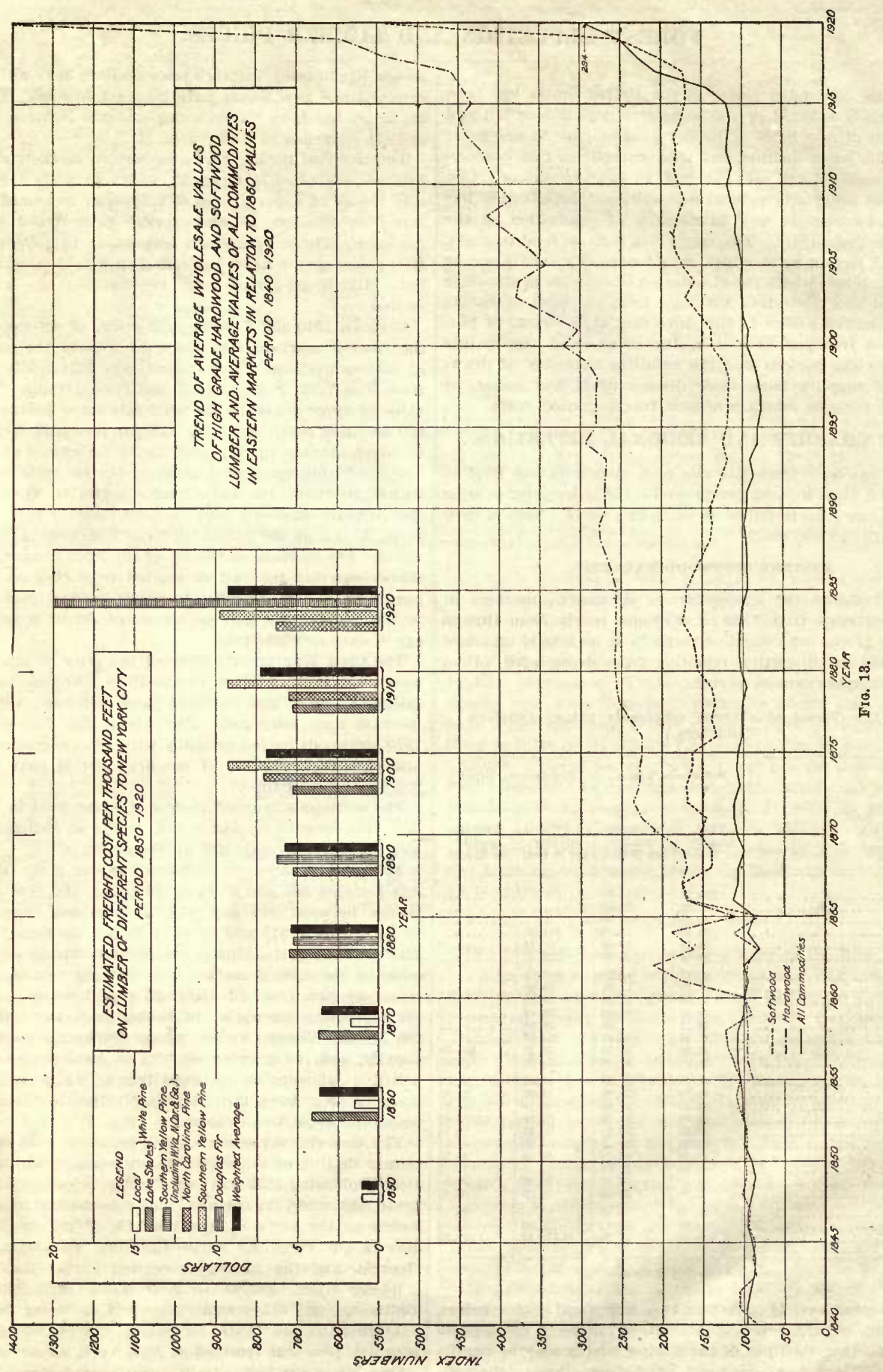


one yellow plne yard in New York, and the receipts were insignificant.

The interregional competitlon which grew ont of the rapld expansion of the Jumber industry in the Iake States and the South during the eightles, together with the continued production in New Fngtand and Pennsylvania, was unquestionably the dominating factor in crowding softwood lumber prices downward and holding them at temporarily tow but fatity uniform polnts fol a decade following 1890 . The average vatue of the upper quality lumber centered about $\$ 30$ per $\mathbf{M}$ feet. and that of the lower quality between $\$ 16$ and $\$ 17$ per $M$ feet. During this period the lumber-price trend colncided very closely with the ups and downs of the all-commodity price average.

13y 1900 the Lake States white pine and the Soutl Atlantic yellow pine were waning factors in the New York market. This was due not only to the decline in cuts in these reglons but also to the increasing absorption of lumber by expancling markets west of New York. The bulk of the softwood lumber in the eastern markets came more and more from the Gulf States by rall and water, with increased transportation charges totaling $\$ 6$ to $\$ 9$ per thousand. This resulted in prices again moving steadlty upward and the establisbment of a new level. The grapli reflects between 1900 and 1906 an increasing divergence of dumber above arernge commodity prices.

From 1903 to 1917 , the period of greatest clecline in the cut of the Inake States, the level of sottwood prices remained fajrly unifor'm. Upper grades averaged from $\$ 40$ to $\$ 45$ and lower grades from $\$ 24$ to $\$ 26$ per thousand, an adrance of from $\$ 10$ to $\$ 15$ and from $\$ 5$ to $\$ 10$, respectirely, over the previous tevel. There were, of course, minor fluctuations, and since 1907 an abnormal pressure downward on prices arising from weals markets and overproduction in most, if not all, of the producing reglons. This is especiatty true of the years 1914 to 1916 , a perlod of great regional competition in all large softwood lumber markets.

In $\mathbf{1 9 1 7}$, it will be noted, the curve for all commodity prices arivanced sliarply beyond softwood lumber prices for the first time since 1865, diue, of course, to war couditions and the fixing of prices by the Government for the nole Important softwood species.

With the close of the war came the opening of a new perlod. Ratdical cbanges had taken place in the generat situation. The strain of overproduction and intense regional and interregional competition was markedly relaxed. The cut of southern pine had falten off some $3 \frac{1}{2}$ billion feet since 1915 , and Jumber production in practically all regions excepting the West was below normal. With the first development of sharp demand following the middle of 1919 , therefore, there was demonstrated as never before in the history of lumber prices the effect of reglonal reduction of Jumber production and its consequent weakening of the great leveling influence of interregional competition.

By March, 1920, average nitl prices in both the South and the West were more than double the average prices received in 1918 and morc than three times those of 1914. These increases were swiftly reflected in the large eastern markets. The average value of upper softwood grades was $\$ 42$ per thousand in 1914 , $\$ 51$ In 1918 , and $\$ 131$ a thousand in March, 1920. Similarly, lower grade material rose from $\$ 25$ in 1914 to $\$ 40$ in 1918 and to $\$ 73$ in 1920 .

These phenomenal price advances, although precipitated by a variety of factors, unquestionably reflect in part a current transition to another lumber price level, the measure of whlch is clouder in present abnormal conditions of trade and finance, supply and demand. The new level will be founded on permanent increases in production costs and the increasing extent to which eastern markets will have to draw upon western Jumber at transportation costs of $\$ 15$ to $\$ 20$ per thousand feet.
Softwood wholesale Iumber prices since 1840 have therefore passed through three maln levels in eastem markets and are now apparently in the initinl stages of the fourth. The first level, prior to 1861 , was characterized by local supplies and upper grade prices of $\$ 20$ to $\$ 25$ ner M. The second extended from 1865 to about 1900 , with prices of from $\$ 35$ to $\$ 40$, and supplies drawn from the Lake States, and the third tevel, from 1900 to 1918, with the Soutlern States as the maln source of supply, and with prices of $\$ 40$ to $\$ 45$. Irices for the fourth level are not yet stable.

\section{MIDDLE WESTERN MARKETS.}

In the markets of the Mlddle West the effect upon lumber prices of changes in sources of lumber supples, with their accompanying clanges in transportation costs, Jumber stocks, and interregional competition, is even morc strikingly shown. These Middle Western markets have during the past 25 years been dominated by first one specles and then another. Each change has grown out of cumulative forest exhaustion or reductions of lumber cut in main forest regions tributary to the markets.

Prior to 1900 tumber stocks in the retall markets of the Midde Western States were largely of white pine from the Lake States, distributed at low transportation costs by water and short rail hauls. Lumber production of the Lake States was at its peak. White pine moved in heavy volume by water to Chicago, and in the form of logs down the Mississippi River. Practically every river town of importance liad one or more saw. mills. Dubuque, Davenport, and Rock Island, atl in the very heart of the consuming region, had, for exampte, many mitts from which lumber was distributed locatty and by rail to consuming markets. Transportation costs were relatively smafl, take rates to Chicago, for exampte, ranging from $\$ 1$ to $\$ 2$ per thousand feet.

Folfowing 1900 the sharp decline in the production of northern pine, due to the exhaustion of the more accessibte forests, was reflected in a gradual shrinkage of whlte-pine lumber from the stocks of retailers farthest removed from the whitepine region. Mills along the Mississippi River, unable tonger to get steady supplies of logs, began to close down. By 1905 most of the mills from La Crosse and Winona downward were idle. Coincident with these movements wholesale and retail lumber prices, even in the southern MInnesota region, began to move upward. Wholesale prices of common grades of northern pine increased $\$ 8$ to $\$ 17$ a thousand feet, while the retall prices advanced $\$ 10$ to $\$ 15$ a thousand feet. This upward movement of average retail prices from around $\$ 16$ in 1895 to $\$ 25$ in 1905 , in response to mitl prices and the declining softwood cut in the Lake States, is clearly reflected in figure 14.

During the same period yeliow plne from the South was moving northward in increasing volume, taking markets whicl northern pine could not supply and exerting through interregional competition a restraint upon increasing white-pine prices. From a production in 1899 of less than $\mathbf{1 0}$ billion feet, the cut of southern pine increased to more than 16 billion feet In 1909, carrying with it a gradual transition of lumber stocks from white pine to southern pine throughout a large part of the region. The southern forests were, however, less accessible to the principal markets of the region, and in place of water transportation in part or in whole, ralt transportation amounting to from $\$ 4$ to $\$ 6.50$ per thousand feet was necessary. This imposed an added cost to lumber and raised the general level of Jumber prices. Had not these great southern forests been avalable to meet the rapidty increasing demands of the reglon and to replace the declining cut of the Lake States, lumber prices in the Middle West following 1905 would unquestionably have reached and maintalned a materially higher level than has actualty existed. 
Following 1912 southern yellow pine was the predoniuant species in the retail yards of Missouri, Kansas, Oklahoma, Nebraska, Iowa, Indiana, and Illinois. It dominated the retail trade. In western Kansas and Nebraska and in North and Sonth Dakota Douglas fir from the coast and western pine from the Inland Empire had largely replaced white pine, while in Wisconsin hemlock formed the principal species in the lumher yards. Only in Minnesota and inmediately contiguous localities was white pine the leading species in the retail trade.

It will be noted from figule 14 that from 1906 to 1917 the level of retail lumber prices fluctuated around $\$ 30$ per thousand feet and mill prices aronnd $\$ 15$. This is explained by the development of further inferregional competition from the western forests.

Following 1900 the cut of the Pacific Coast States increased rapidly from about 3 billion to more than 7 billion feet in 1910. Surplus stocks soon begin to move eastward, and Douglas fir from the West Coast and western pine from the Inland winpire became active factors in the northern-pine markets of the Dakotas and Minnesota and in the southern-pine markets of western Nebraska and Iowa. The period 1908 to 1916 was one of periodic business depression and overproduction at the mills. In order to move stocks of lumber in the South and in

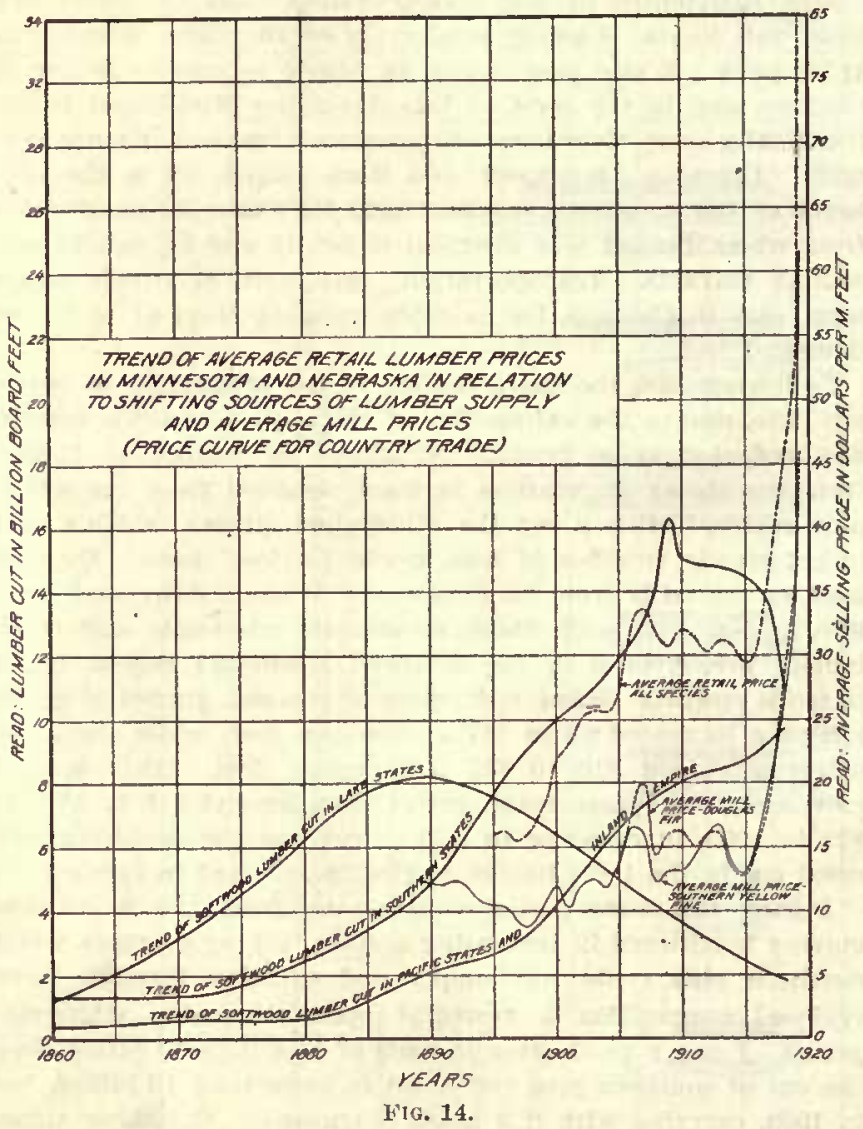

the West, prices were often sel af cost of moduction or less. Southern pine and Douglas fir met in keen competition in the Prairie States. This expanrling movement in yellow pine and Douglas fir competing for markets naturally exerled a leveling pressure upon lumber prices. It was a buyers market. Buyers whipsawed the price of one species against the ofher, and thereby exerted further pressure downward on hotil wholesile and retail prices.

From the standpoint of the public, or the lumber cmisumer, the situation is illustrative of the great economic arlvantage of having large avallahle forests in different producing reglons. When the supply of lumber from the Lake States tirst began to decline radical price advances were unquestlonably prevented by the inflow of a great volnme of lumber from the Soutb. As the southern pine lumber established itself in the markets of the Middle West. the exhaustion of timber in the Lake States reached a point where northern pine and benlock ceased to become effective competitive factors, excent in very limited regions, but fulther alvances in lumber prices were checled by the great inflow of lumber from the West.

The increasing volume of western lumber in the niddle western market: obviously increased the freight rates borne by lumber. That these increases are not reffected by figure 14 is due to the fact that during the period 1910 to 1916 they were largely absorbed by the mills in lieu of protits in order to move surplus stock. These ronditions are slown graphically ln tigure $\mathbf{1 5 .}$ They therefore have acted as springs, exerting pressure upward and Intensifying the responsiveness of prices to any release of pressure from ahove. In the letatl trade of southern Minnesota, for exanple. the average transportation cost bolne by lumber in 1905 arnounted to about $\$ 3$ per 1,000 feet. In 1915 it had increased to $\$ 8.50$, and in 1919 to practically $\$ 12$ per 1,000 feet.

Normal markets for lumber in the Middle West largely disappeared during the war. The needs of the Nation in prosecuting the war, lowever, eventually ahsorbed available lumber sturks. There was litfle activ' demand for lumber, but potential demands steadily accumulated. In the meantime lumber production in almost all regions declined. Restrictions on lumher were lifted following the ambtlce, and the great pent-up dionind for lumber was released into normal clannels of trade. ['rewar conditions of lusiness delression and overproduction at the lumber mills liad passod. There devetoped, indeed, a striking reversal of those conflitions. Lumber was needed in great volume to supply the shortage of homes and other buildings. Wood-using ludustries were slort of lumber to resume business on a prewalr scale. Industries began to expand on the abnormal increase of credit growing out of war financlng. Production of southern pine lumber had passed its peak. The Soutl was prosperous and in need of lumber. It absorbed the "ut of southern mills at high prices in greater volune than ever hefore, while eastern markets likewise drew more heavily upon 11., Soutlı.

As a lesult of the foregoing conditions, the former doninating and far-reaching competition of yellow pine was much contracterl, and the great markets of the Middle West were left primarily dependent upon timber from the Pacific coast and the Inland Inupire. The greatly reduced cut of the Lake States. for:ests was wholly ineffective as a competitive factor in exerting a leveling infuelle upon prices, and the upward pressure of increased transportation costs and lean profit years prior to the wall was set free to act. Within a year or 18 months Donglas fir becume the principai species throughout the greater portion of the Mirldle West. To-day it forms 80 to 90 per cent of the retail stocks in Minneapolis, which has always been a great white-pine market. It is found in Chteago in greater volume than any other species. In Kansas City, whlich is on the rery edge of the southern pine district, it forms more than 5o jer cent of the lumber stocks.

In the foregoing (onditions may be found the underiying causer for the chatic price situation which developed in these micille western murkets during the latter part of 1919 and the first montlss of 1920. Beginning with June, 1919, prices. moved steadily upward. It was the beginning of an intensified sellers' market. Wholesale and retail lumber prices reached the highest point in the history of the industry. As shown by figure 19, the average sales values of retall stocks in country districts in Harch were around $\$ 85$ per 1,000 feet, while average wholesale inill prices langed from $\$ 45$, to $\$ 60$. The trade was plunged into confusion. Buyers needed lumber and were wilting to bid for it. For several montlis prior to March, 1920, lumber practically lost unitolmity of vrice in many markets. Quotations in 

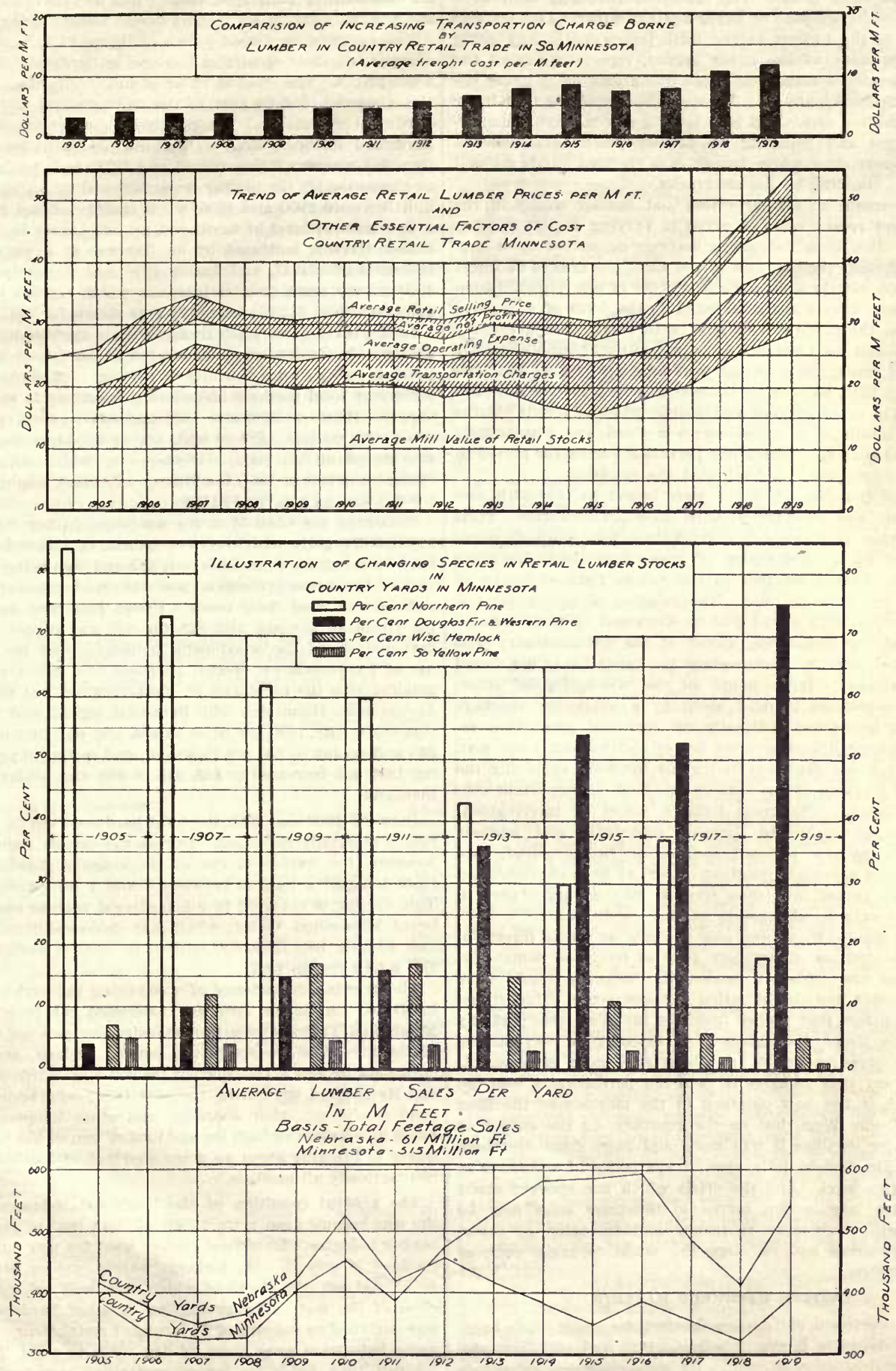

FIG. 15. 
the same market varied from $\$ 2$ to as much as $\$ 50$ per thousand feet on the same grade. The tables of 1914 and 1915 were turued. Sellers whipsawed buyer agalnst buyer. Lumber was auctioned to the highest bidder, with prices continually going higher. On some of the upper grades, especially among the hardwoods, sellers lefused to make quotations or to grant options on expected matcrial. Through the use of the transit-car privilege dealers often held cars for big prices, paying demurrage charges and gambling on further price advancements. Instances were cited where transit cars changed hands six and eiglit times standing on the sidetracks.

The novement of lumber prices and lumber stocks in the Middle West reflect what occurred in varying degree in practically all other large consuming markets dependent upon lumber from distant regions. As in the East, the effects of forest depletion are clearly discernible. Because of interregional competition these effects are manifested in the form of successive price levels, the first prior to 1900 , with retail price averaging around $\$ 16$ and the Lake States as the source of supplies; after a period of transition a second, beginning about 1906 and lasting through 1916, with prices centering around $\$ 30$ for southern lumber. The rapid advance and chaotic prices of recent months are srmptomatic of a transition to a third and permanentiy higher level than that which has prevalled during the period in which southern pine has domiuated the situation.

It is true that lumber prices were bound to rise with producing costs and in common with other commodities. It is true also that their sudden skyrocketing was unquestionably precipltated by a combination of many conditions, inciuding unfavorable logging weather in the South, reduced stocks at the mills, car shortage, etc. The relation of producing and distributing costs to prices will be discussed in a subsequent section and the underlying cause of the extraordinary and unprcedented price movement since the armistice is not found in that relation. It is found In the weakening of interregional competition brought about by a temporary shortage of lumber, accasioned primarlly by curtailed production resulting from conditions growing out of and following the war. Cumulative forest depletion in regions formerly supplying the big lumber markets of the country has been an important contributing fuctor. The great balance wheel of interregional competition is unable to function effectively" and without interruption as the regional sources of timber suppiy are exlaausted and abnormal conditions, such as have characterized the postwar period, are thus free to play a larger part in violent and extreme changes in market conditions.

Had the Middle West been able to draw on ample forests of northern as well as of southern pine to meet the demand of an enlarged and insistent market the response would have been far easier and the situation far less acute. Had it not been for the fact that timber from the far West was partially availabie to lessen the strain of a demand far beyond the supply the pressure would have been still more extreme. It is safe to say that Douglas fir will not permanently lose the place which it has now obtained in the markets of the East and the Middle West, but on the contrary, as the output of southern pine declines it will more and more dominate those markets. The freight tolls upon it are being incorporated in the new price level. And the crisis which has brought about its extensive introduction serves to illustrate what may be expected with increasing frequency and intensity as forest depletion proceeds and no steps are taken to make cut-over lands productive.

\section{FASTERN HARDWOOD MARKETS.}

Wholesale prices in the eastern markets for upper grade hardwoods are shown in figure 13 between $1855^{\circ}$ and 1920 , and also with material of arcrage quality for somewhat shorter periods in Table 11. The hardwood price curve follows closely that for all commodities until 1860, since when they have heen separating gradually except for a short perlod following the Civil War.

The curve of hardwood prices in figure 13 indicates a much sharper and more consistent increase in hardwood than in softwood prices. The leveling effect of interregional competition is less apparent, due in part to the more general distribution of hardwood forests and the relatively snaller consumption of hardwood lumber. Four rather distinct price levels are apparent, however. Between 1865 and 1875 there was a rapid rise to almost double the prewar level, followed by a steady increase until between 1900 and 1905, when another abrupt rise marked a new general level of hardwood prices. Again .In 1915 a still higher level is indicated by an increase of more than $\$ 10$ a thonsand over 1917, and during 1919 and the early months of 1920 a very much greater increase, which carried the average price to almost $\$ 125$ in excess of that shown for 1917.

In the early days, when transportation systems in the United States were undeveloped, commerce in hardwood lumber was limited, owing to the difficulty of rafting. Its consumption was mainly by local markets immedintely tributary to the source of suppiy. Between 1850 and 1860 hardwoods were cut near the consuming centers. Prices were low and the quantity consumed was comparalively small. Filst-quality white oak sold in the eastern markets in 1855 for $\$ 10$ per 1,000 feet wholesale, poplar for $\$ 11.50$, and ash for $\$ 10.50$.

Following the Civil War the conmerce in hardwood Iumber expanded rapidly with the development of railroads. By 1870 hardwood lumber from Ohlo and Indiana was being shipped by rail to the eastern markets, and the locai cut was no longer sufficient to meet their needs. Prices had risen to about $\$ 26$ per thousand for oak and $\$ 25$ for ash and poplar. With the development of the wood-using industries and the increasing use of hardwoods for special purposes, the industry began expanding into the highlands of West Virginia and the southern Appalachian Mountains with increased logging and transportation costs. By 1890 the price of ash and oak had increased to $\$ 35$ and poplar to $\$ 30$ per thousand, and in the 10 years following 1890 oak increased to $\$ 43$, ash to $\$ 45$, and poplar to $\$ 36$ per thousand.

Between 1900 and 1909 the totai hardwood cut in the United States gradually increased. During the decade following 1910 , however, the hardwood cut of the country steadily declined fiom ten and $a$ half to between 6 and 7 billion feet in 1918 . This decline is reflected in all hardwood regions excepting tlie lower Mississippi Valley, which has increased from a produetion slightly less than 800 million in 1900 to alınost a billion and a haif feet in $\mathbf{1 9 1 7}$.

The growing dependency of wood-using Industries and other hardwood consumers upon the hardwood cut from the lower Mississippi Valley serves to emphasize the growing exhaustion of the hardwood forests in the central, eastern, and northern hardwood regions. The South is the last large liardwood reserve, and its reduced cut during the past two years, because of bad flood conditions, labor shortage, and other temporary factors which bave curtalled both $\log$ and lumber output has been a large factor in bringing about an acute shortage of hardwood lumber in practically all markets.

The general condition of the hardwood industry following the war became even more unsettled than that of the softwood Iumber industry. Hardwood lumber used for war purposes was confined largely to oak, hickory, walnut, yellow poplar, basswood, and ash, the stocks of which were well exhausted by the close of the war. The production of other hardwood species was curtafled on account of Government restrictions. The woodusing industries were short of dry stock to meet the demand for furniture, finish for homes, and other hardwood products. 
The result was that hardwood lumber was bld up to unprecedented prices. The market became extremely erratle and unstable. Several species such as ash practically disappeared from the market. Quotatlons often ald not hold good overnight. It was not uncommon for cars of lardwood lumber to net the owners profits of $\$ 50$ to $\$ 100$ and over per 1,000 feet. As an exanıple, a jobber who had bought a car of quarter-sawed oak from a small mili operator for less than $\$ 100$ per thousand immediately sold it for $\$ 400$ per 1,000 feet.

Wholesale and retail prices in 1920 of a number of the more important hardwoods In relation to prices prevalling in prevlous years are shown in Table 12 . The growing scareity and high prices of oak are probably of greatest concern, because it is used by such a great varlety of industrles and consumers. The cut of oak reached its peak with the decade between 1899 and 1909. For the two years mentioned the cut was Identical and amounted to nearly $4 \frac{1}{2}$ billion feet. Since 1909 there has been a general falling off in production, and in 1917 the cut had dropped to a total of 2 bllition and was only 44 per cent of the cut in 1909 .

The lower Mississlppi Valley holds the last large reserves of oak timber ln the Unlted States. The cut in these States decreased from about 715 million feet in 1909 to about 470 million feet In 1917. In 1913 the wholesale price of F A S quartered white oak, used generally by the furniture and musical instrument manufacturers, was about $\$ 80$ per thousand. In February, 1920 , It had risen to about $\$ 300$, and was difficult to procure at that price. To manufacture quartered oak first quality, large sized, straight-gralned logs are requlred, whlch are obtalned only from old growth or vlrgin tlinber. Qually depletlon of timber is linportant in thls case.

TABLE 12.-Wholesale and retail prices of hardwood lumber at various points throughout the United States.

WHOLESALE PRICES (DOLLARS PER 1,000 FEET).

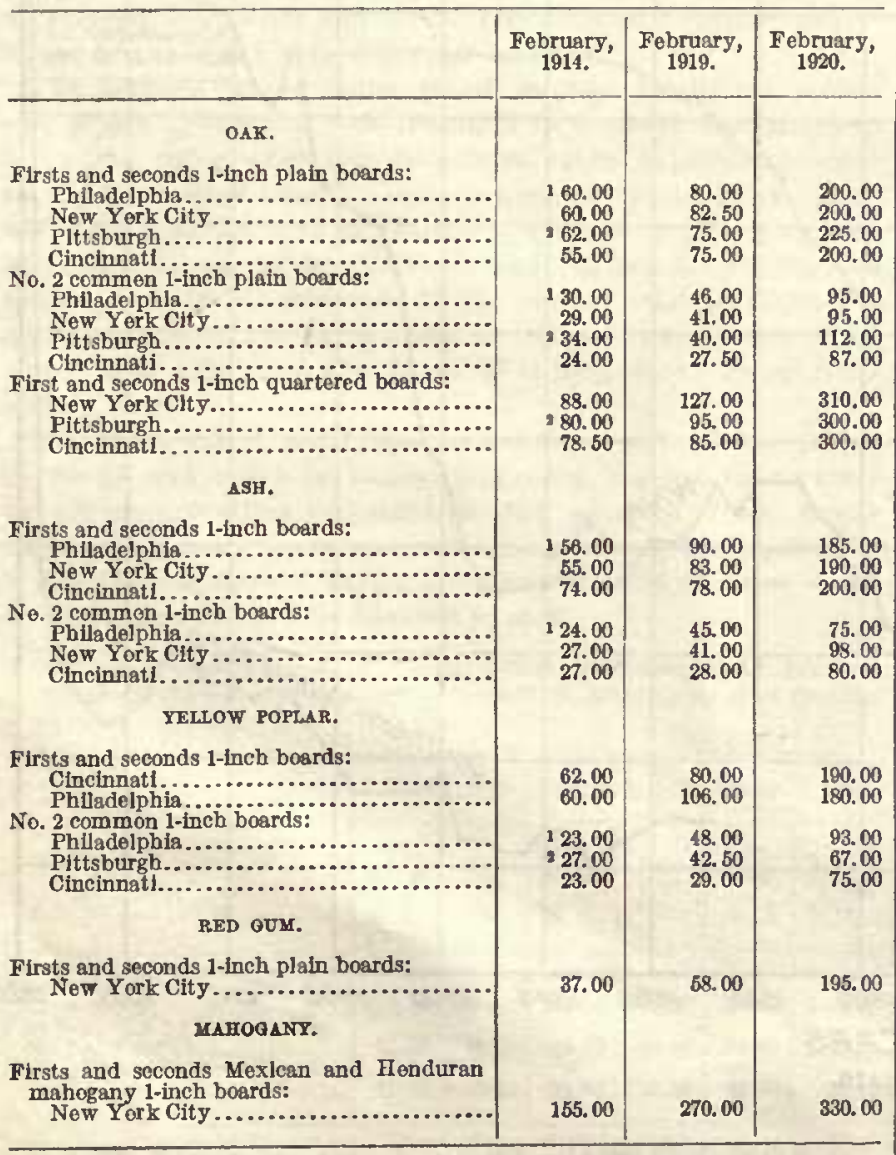

TABLE 12.-Wholesale and retail prices of hardwood lumber at various points throughout the United States-Continued. RETAIL PRICES (DOLLARS PER 1,000 FEET).

\begin{tabular}{|c|c|c|c|}
\hline & $\underset{1914}{\text { February }}$ & $\begin{array}{l}\text { February, } \\
1919 .\end{array}$ & $\begin{array}{l}\text { February, } \\
1920 .\end{array}$ \\
\hline OAK. & & & \\
\hline 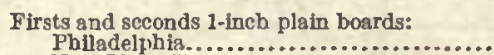 & & & \\
\hline New York City.... & & 132.00 & 252.50 \\
\hline ............... & & $\begin{array}{l}100.00 \\
100.00\end{array}$ & $\begin{array}{l}260.00 \\
265.00\end{array}$ \\
\hline No. 2 common 1-inch plain boards: & & & \\
\hline City.............. & 58.00 & & \\
\hline Pittsl & & 154.00 & 150.00 \\
\hline ds $1-$ inch qu & 31.00 & 46.50 & 116.00 \\
\hline rsts and secondity.i...... & 00 & .00 & 400.00 \\
\hline 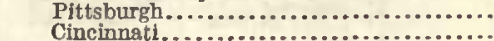 & & & \\
\hline Cincinnati.............. & 106.00 & 115.00 & 385.00 \\
\hline ASIf. & & & \\
\hline $\begin{array}{l}\text { Firsts and seconds 1-Inch boards: } \\
\text { Philadelphia..................... }\end{array}$ & & & \\
\hline ity....... & 95,00 & 138.00 & 245.00 \\
\hline 1-inch boards: & 97.50 & 105.00 & 265.00 \\
\hline k city ................. & 45.00 & 60.00 & 10000 \\
\hline YELLOW POPLAR. & & & \\
\hline $\begin{array}{l}\text { Firsts and secends 1-inch boards: } \\
\text { Cincinnatt............................ }\end{array}$ & 83.00 & 106.50 & 253.00 \\
\hline -inch boards: & & & \\
\hline 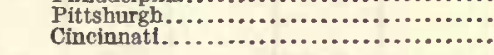 & $\begin{array}{r}136.00 \\
30.50\end{array}$ & $\begin{array}{l}56.00 \\
39.00\end{array}$ & $\begin{array}{r}85.00 \\
100.00\end{array}$ \\
\hline RED & & & \\
\hline $\begin{array}{l}\text { Firsts and seconds 1-inch plain boards: } \\
\text { New York City.......................... }\end{array}$ & & 102.00 & 247.60 \\
\hline 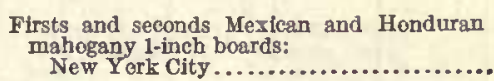 & 175.00 & 330.00 & 400.00 \\
\hline
\end{tabular}

1 February, 1913.

Red gum, whlch 20 years ago was considered a weed tree and little cut for lumber, commands a wholesale price of $\$ 200$ per thousand for F A S figured and $\$ 180$ for F A S plain. Plain oak flooring in 1913 in Ohlo citles retalled for about $\$ 75$ per 1,000 feet. In March, 1920, the same material brought $\$ 300$ per 1,000 feet. White ash trim F A S In 1913 retalled for $\$ 72$ per 1,000 feet To-day it is very difficult to procure and quotations are not generally avallable; however, sales have been made at $\$ 265$ and over per 1,000 feet. Maple floorIng In 1913 retalled for $\$ 60$ and in March, 1920, for $\$ 240$. Yellow poplar F A S in 1913 retailed for $\$ 70$ and in February, 1920 , for $\$ 225$.

Wholesale prices for hardwoods in the eastern markets are therefore characterlzed by more continuously rislng prlces and mucl less pronouriced price levels than for softwoods. This is the logleal result of the distribution of hardwoods, the larger bodies of which merge Into each other and are less distinct than the princival softwood regions. The center of hardwood production has therefole moved gradually away from the center of consumption. The $\$ 10$ wholesale price for first quality whlte oak of $1855 \mathrm{had}$, by the early months of 1920 , reached $\$ 230$, and the prlces of other species had increased proportionately. Without minimizing other factors that have affected prices, the effect of depletion is not less clear or pronounced than in the case of the softwoods.

The foregoing Increases illustrate the effect of growlng scarcity and regional forest exhaustlon upon the price movements of species of general and special use. This is further brought out graphleaily in figure 16, which shows the prlce trend of walnut, a specles of llmlted quantity and speclal use, 


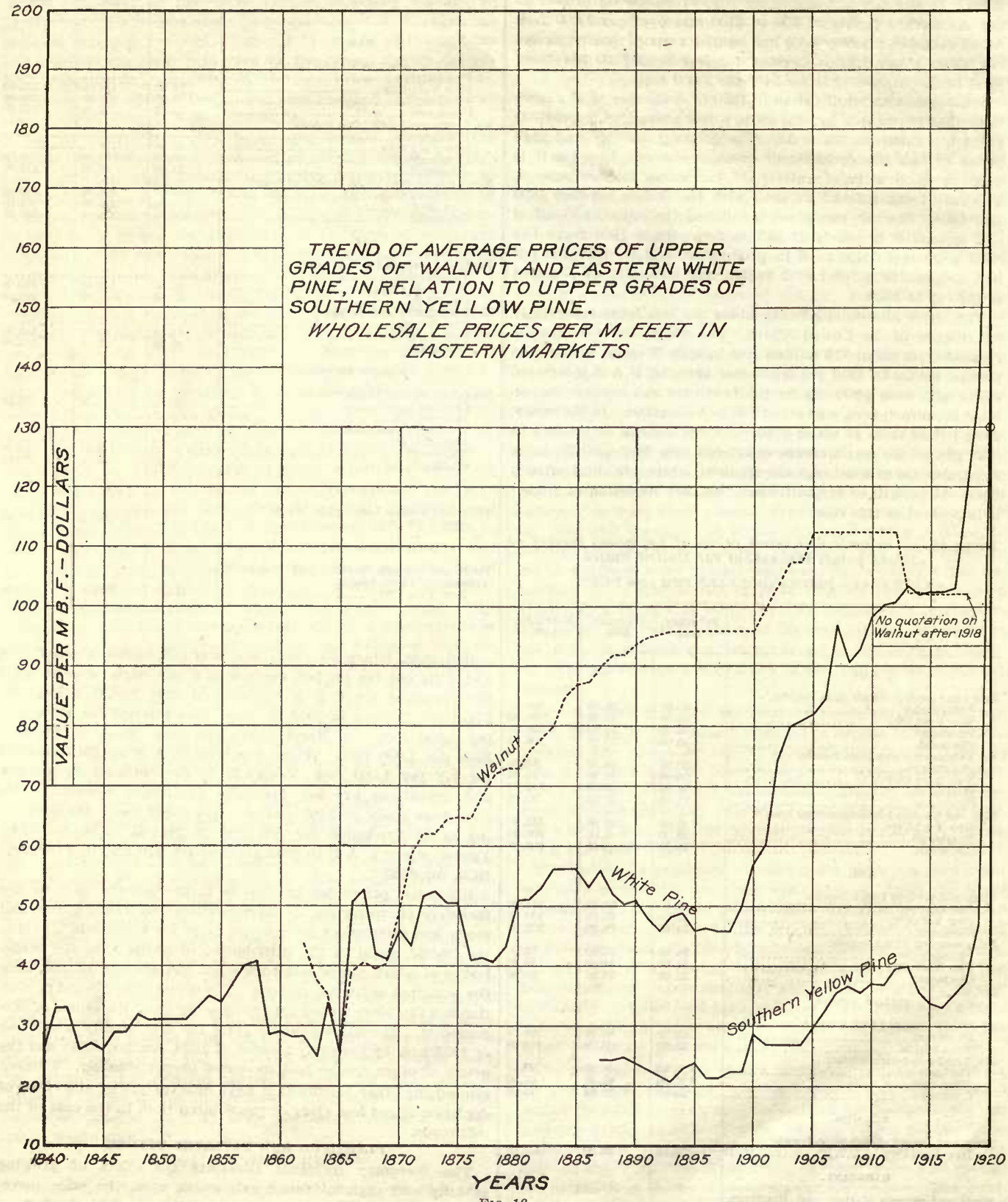

FIG. 16. 
and of the upper grades of white pine, a speeies formerly available ln large quantities and of general utillty, but now nearing exhaustion, ill relation to upper grades of southern pine, " wood of present large-quantity production. The curve for walnut, it will be noted, shows a lise in price fromr $\$ 25$ in 1865 to $\$ 112$ in 1905 , without a single (lrop). Thls was undoubtedly dufe to the comparatively small orlginal stand of walnut. At present firms handling walnut in quantlty hare scouts in the held searching out and buying single trees to supply their needs.

In contrast to walnut prices, the prices of white pine were only slightly higher in 1895 than in 1866. During this period white plne was the general utllity wood. It was avallable in large quantities in pure stands first in southern New England, then in New York and Pennsylvanla, and later in the Lake States. To-day it is largely a specialty wood. The transition from " general utility to a specialty wood following 1900 is strikingly llustrated by the marked divergence of the whitepine curve from the southern-pine curve. The difference in price in 1900 of approxlmately $\$ 20$ per thousand had renched $\$ 70$ ln 1915 and $\$ 130$ in 1920.

\section{PRICES IN DEPLETED OR NONFORESTED VERSUS FORESTED REGIONS.}

Retail prices eollected Indicate that in normal thes and much more during periods of shortage and extreme prices, such as the present communities. close to large lumber-producing regions, beneflt very materlally in lumber prices. Hetail lumber sales in produclng reglons of the South and the West are often made at rates which check elosely with wholesale prices in the respectlve regions. This is an atvantage whlch formerly forested reglons, such as the Take States, I'mnsylvania, New York, and New Fngiand have now lost. Lumber dealers in produchng territories are able to handle lumber on a smaller margin than retallers at dlstant points, primarily because they are near the source of supply and are not required to carry large stocks or to buy lumber far in advance in anticlpation of delayed shlyments aud traftic breakdowns. 1'resent differences, however, far exceed prewar margins.

Furthermore, many mills retall lumber locally at wholesale prices. Instances were found, in fact, where speclat prices below the golng wholesale price were made by mills in order to stlinulate local building and communlty development. Reclwood bevel siding sold in February, 1920, at a produeing city In Callfornla for $\$ 40.90$ wholesale and $\$ 43$ petail. During the same month in Washington, D. C., and at Dayton, Ohio, the quoted prices on the same material varied from $\$ 110$ to $\$ 130$. The frelght rate from California to these points was approximately $\$ 8.50$.

The three tables which follow Indlcate retail selling priees in towns and eitles in lumber-producing legions in contrast to prices prevalling in markets far removed from forest regions. In some instances, sale prices and price quotations from different dealers varied considerably, and in these cases an average of the prices obtalned is used.

TAnce 13.-Comparison of retuil priees per thousund feet of North Carolina pine lumber at points in producing and in eonsuming regions.

\begin{tabular}{|c|c|c|c|c|c|c|}
\hline \multirow[b]{2}{*}{ Nerth Carelina pine. } & \multicolumn{2}{|c|}{ Fobruary, 1914.} & \multicolumn{2}{|c|}{ February, 1919.} & \multicolumn{2}{|c|}{ February, 1920 . } \\
\hline & $\begin{array}{c}\text { Wil- } \\
\text { ming- } \\
\text { ton, } \\
\text { N.C. }\end{array}$ & $\begin{array}{l}\text { New } \\
\text { York } \\
\text { City. }\end{array}$ & $\begin{array}{l}\text { Wil- } \\
\text { ming. } \\
\text { ten, } \\
\text { N. C. }\end{array}$ & $\begin{array}{l}\text { New } \\
\text { Yerk } \\
\text { City. }\end{array}$ & $\begin{array}{l}\text { Wil- } \\
\text { ming- } \\
\text { ten } \\
\text { N. C. }\end{array}$ & $\begin{array}{l}\text { New } \\
\text { Yerk } \\
\text { City. }\end{array}$ \\
\hline 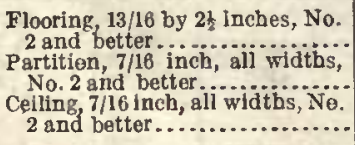 & $\begin{array}{r}\$ 25.00 \\
27.50 \\
18.00\end{array}$ & $\begin{array}{r}838.00 \\
45.00 \\
27.50\end{array}$ & $\begin{array}{r}\$ 45.00 \\
50.50 \\
32.00\end{array}$ & $\begin{array}{r}\$ 62.50 \\
64.50 \\
55.00\end{array}$ & $\begin{array}{r}898.50 \\
101.00 \\
46.00\end{array}$ & $\begin{array}{r}\$ 150.00 \\
150.00 \\
91.50\end{array}$ \\
\hline
\end{tabular}

The freight rate from Wilmington, N. C to Nere Yark City ameunted to appreximately $\$ 3.25$ per 1,000 foet in 1914 and te $\$ 4$ per 1,000 feet in 1919 and 1920 .
CAJSIE 14.-Comparison of retail priees of southern yellow pine lumber in South with prices in consuming region.

\begin{tabular}{|c|c|c|c|c|}
\hline \multirow[b]{2}{*}{ Southern yellow pine. } & \multicolumn{4}{|c|}{ February, 1920.} \\
\hline & $\begin{array}{l}\text { Peints in preducing } \\
\text { region. }\end{array}$ & $\begin{array}{l}\text { A verage } \\
\text { selling } \\
\text { price } \\
\text { per M } \\
\text { feet. }\end{array}$ & $\begin{array}{c}\text { Peints in censuming } \\
\text { regien. }\end{array}$ & $\begin{array}{l}\text { A verage } \\
\text { selling } \\
\text { price } \\
\text { per } \mathrm{Il} \\
\text { fcet. }\end{array}$ \\
\hline \multirow{5}{*}{$\begin{array}{l}\text { F looring, } 1 \text { by } 4 \text { inches, } \\
\text { B and better, flat } \\
\text { grain..................... }\end{array}$} & $\mathrm{M}$ & $\$ 115.00$ & Kansas City, M & $\$ 133$. \\
\hline & Mon & & Lincoln & 125.00 \\
\hline & Bogalusa, La... & $\begin{array}{l}110.00 \\
110.00\end{array}$ & $\begin{array}{l}\text { Country town, Kans. } \\
\text { Dayton, Ohie....... }\end{array}$ & $\begin{array}{l}190.00 \\
150.00\end{array}$ \\
\hline & Pens: & 110.00 & Pittsburgh, $\mathbf{P a}$ & 142.00 \\
\hline & & & Kansas City, M & \\
\hline \multirow{3}{*}{$\begin{array}{l}\text { Dimensions, } 2 \text { by } 4 \\
\text { inches, } 16 \text { feet } \mathrm{S} . \& \\
\mathrm{E}, \mathrm{No} .1 \text {, common.. }\end{array}$} & Mentzomery, & 50.60 & Chieago, $111 . .$. & 65.15 \\
\hline & Begalusa, La. & 53.00 & Country rown, & 70.00 \\
\hline & $\begin{array}{l}\text { Pensacola, Fla.. } \\
\text { Mobila, Ala.... }\end{array}$ & $\begin{array}{l}55.00 \\
56.00\end{array}$ & Kansas City, Mo.... & 66. \\
\hline \multirow{4}{*}{$\begin{array}{l}\text { Cemmon beards, } 1 \text { by } \\
8 \text { inehes, Ne. } 2, \text { S2S. }\end{array}$} & 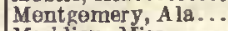 & 51.60 & Ceuntry tewn, Kans. & 70. \\
\hline & Meridian, Miss. & 61.50 & Chicago, I1l.... & 68. \\
\hline & $\begin{array}{l}\mathrm{Bag} \\
\mathrm{Pen}\end{array}$ & $\begin{array}{l}57.00 \\
60.00\end{array}$ & $\begin{array}{l}\text { Daytan, Ohio... } \\
\text { Pittsburgh, } \mathrm{Pg} \text {. }\end{array}$ & $\begin{array}{l}80.00 \\
80.00\end{array}$ \\
\hline & Ala.. & 110.00 & Kansas City, Mo. & 139.40 \\
\hline \multirow{3}{*}{$\begin{array}{l}\text { Finish, } B \text { and better, } \\
1 \text { by } 6 \text { inches, } 8 \text { feet.. }\end{array}$} & Montgomery, Ala & 120.00 & Chicage, Ill.. & 135.00 \\
\hline & Meridian, Mlss. & $\begin{array}{l}114.00 \\
112.50\end{array}$ & Lincoln. Nebr. & $\begin{array}{l}135.00 \\
145.00\end{array}$ \\
\hline & Begalusa, La... & 115.00 & Dayten, Ohlo....... & 175.00 \\
\hline
\end{tabular}

The frelght rates per 1,000 fect from southern yellow pine mill points to Kansas City, Mo., Linceln, Nebr, and to Chicage, lll., Dayton, Ohle, Pittsburgh, Pa., ameunted te approximately $\$ 7.25, \$ 7.90, \$ 6.50$, and $\$ 7.50$, respectively.

TABLE 15.-Comparison of retail prices of Douglas fir on West Coast with prices in consuming region.

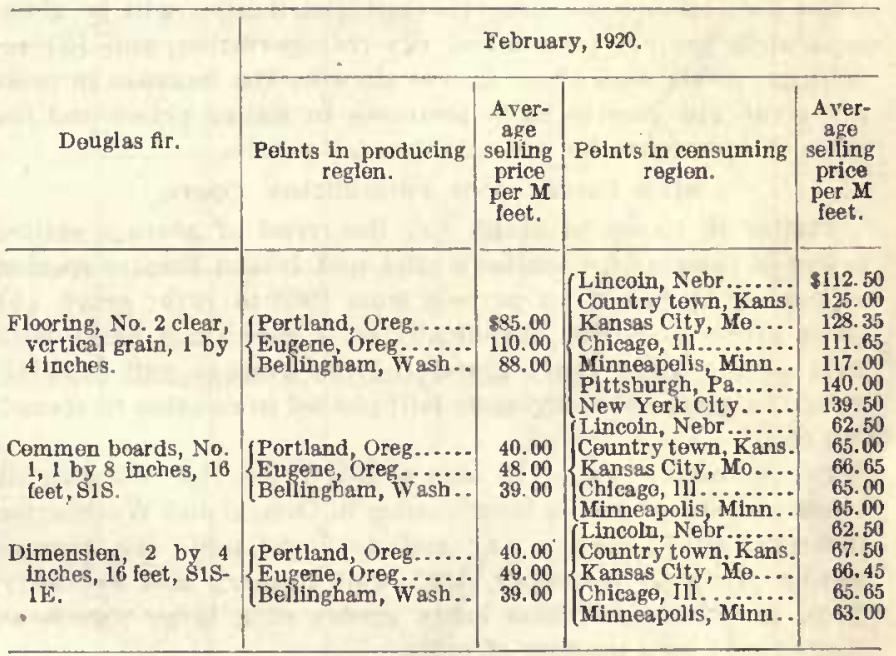

'The frelght rates per 1,000 fcet from the West Coast to Lincoln, Nebr., and Kansas Clty, Mo., Minneapelis, Chicago, Pittsburgh, and New York City amounted te approximately $\$ 13.75, \$ 12.50, \$ 15, \$ 18.60$, and $\$ 20$. respectlvely.

Differences shown in the foregoing tables are in most cases very striking. No. 2 and better flooring of North Carolina pine, for example, was retalling at around $\$ 150$ in New York in February, 1920, but was retailing in Wilmington, N. C., at about $\$ 100$ per 1,000 feet, although the freight rate to New York amounts to only $\$ 4$ or $\$ 5$ a thousand. Similarly, No. 2 southern pine common boards 1 by $S$ inches were being bought in southern cities at from $\$ 50$ to $\$ 60$ a thousand feet, but were costing $\$ 80$ a thousand in Dayton, Ohlo, and Pittsburgb, 1’a., despite freight rates equivalent to only about $\$ 6.50$ and $\$ 7.50$, respectively. In the case of Paclfic coast Donglas hir floorlng No, 2. clear vertical grain, 1 by 4 inches, average retall prlces were as low as $\$ 85$ in some western cltles and as high as $\$ 140$ in somf eastern, with freight rates of $\$ 20$ or less. In some cases thr difference between present rerall prices in producing regions plus frelght and retail prices in consuming regions exceeds the total prewar prices in the consuming region.

Twenty years ago sawmills in Minneapolis were cutting more than 500 million feet of Jumber annually. As tributary forests became exhausted these mills were forced one by one to close down. The last remaining mill closed a year ago, and one of the larger citles of the country; as well as the rich agricultural 
region surrounding it, is to-day forced to obtaln from 80 to 90 per cent of the lumber from Pacific coast forests some 2,000 miles distant. Douglas fir, common dlmension, 2 by 4, from western Oregon and Washington, for example, cost at retall in Minneapolis in February, 1920, $\$ 60$ to $\$ 65$, whereas in 19002 by 4 dimension of wlilte pine could be purchased for $\$ 15$ to $\$ 20$. The growing scarclty of white pine has constantly tended to enhance its value. During January and February of this year it is sald that the relatively few remaining northern pine mills could obtain almost any price desired for their lumber cut. Price lists recently issued by two groups of mllls, for example, quoted prices varying $\$ 15$ or more on the same grades. Figure 17 reflects wholesale prices of three grades of northern pine in Minneapolis at intervals of five years from 1900.

Even in normal times lumber purchasers in nonforested and depleted reglons are at a distlnct disadvantage over purchasers In regions of lumber production. This disadvantage becomes much more pronounced in times of scarcity and unsettled conditlons such as the present, when the excess in retail prices, leducting all transportation costs, may even exceed the total price of the same grades under normal conditlons.

\section{PRICES AND COSTS OF PRODUCTION AND DISTRIBUTION.}

Flgures indicative of the increasing costs which have entered into lumber manufacture and distributlon will be given separately for (1) production, (2) transportatlon, and (3) retalling. Along with these figures showing the increase in costs are given also figures as to increases in selling prlces and the ratio of transportation charges to retall prices.

\section{MILL PRICES AND PRODUCTION costs.}

Iigure 18 shows in graph (a) the trend of average selling nrices of Douglas fir, southern plue, and Inland Empire specles, separately by years, for periods from 1905 to 1919 ; graph $(b)$ these prices expressed graphlcally on a percentage basis, with 1914 as the Index year; graph $(c)$ the average mill price received by a typical Douglas fir mlll plotted in relatlon to operating cost.

Pacific coust.-Table 16 shows mill prices for Douglas fir lumber produced on the Pacific coast in Oregon and Washlngton incorporated in graphs $(a)$ and $(c)$, and adds the average selling prices in December, 1919, and January and February, 1920 , as determined from index grades of a large volume of lumber sold by a number of mills.

'I'ABLE 16.-Average price per thousand feet lumber tally.

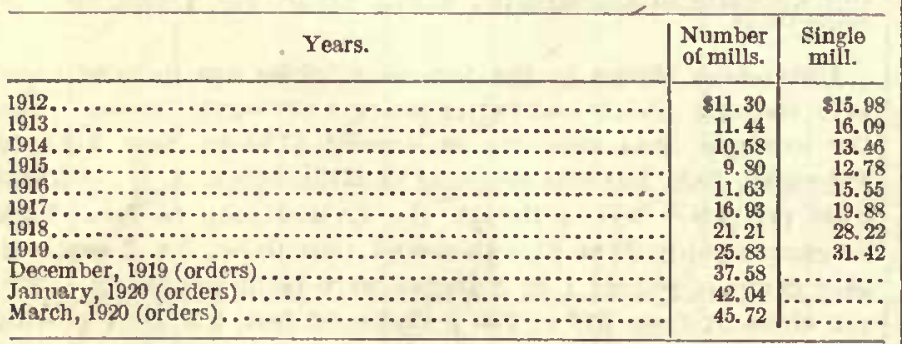

The average prices shown above for a number of mills do not include underweights and sales of special stock and by-products, which would tend to Increase them sllghtly. The two sets of prices as given above are believed to be representative of hlgh and low average mlll prices.

Compilations prepared by the West Coast Lumbermen's Assoclation show that manufacturers west of the Cascades recelved In 1919 an average of $\$ 25.70$ per 1,000 feet for all species. The association's figures are based upon data from 50 mills, and the average prices received by the different mills, including returns from lath, wood, and sawdust, range from $\$ 20.50$ to $\$ 35.50$, a varlation of $\$ 15$. It is fair to assume, therefore, that the average mill price of Douglas fir during 1919 was between $\$ 25$ and $\$ 30$ per 1,000 feet.
The average mill prices glven for the months of December, 1919, and January and March, 1920, are based on sales reported to the West Coast Lumbermen's Association, and represents a large volume of business. It will be noted that the average price for Marcl (based on orders taken) amounted to over four and a half tlmes the average price received in 1915, and is $\$ 20$ higher than the average price shown for 1919.

A comparison of 1919 production costs in thls region wlth costs in 1913, 1914, and 1915 indicates that the cost of produclug lumber has a little more than doubled. On the basls of information collected and compiled by an accountant employed by the West Coast Lumbermen's Associatlon, the average cost of logging Douglas fir by manufacturers in Oregon and Washlngton during 1919 amounted to $\$ 10.89$, this figure being an average of an output of about 1 billion feet. Costs of manufacture show similar increases. In 1915 the average manufacturing costs of 30 mills in Oregon and Washington was $\$ 5.53$ per 1,000 fect, whlle in 1919 the average manufacturing cost, as determined by the West Coast Lumbermeu's Assoclatlon, amounted to $\$ 10.21$ per 1,000 feet, or, with sblpping and selling included, $\$ 11.83$.

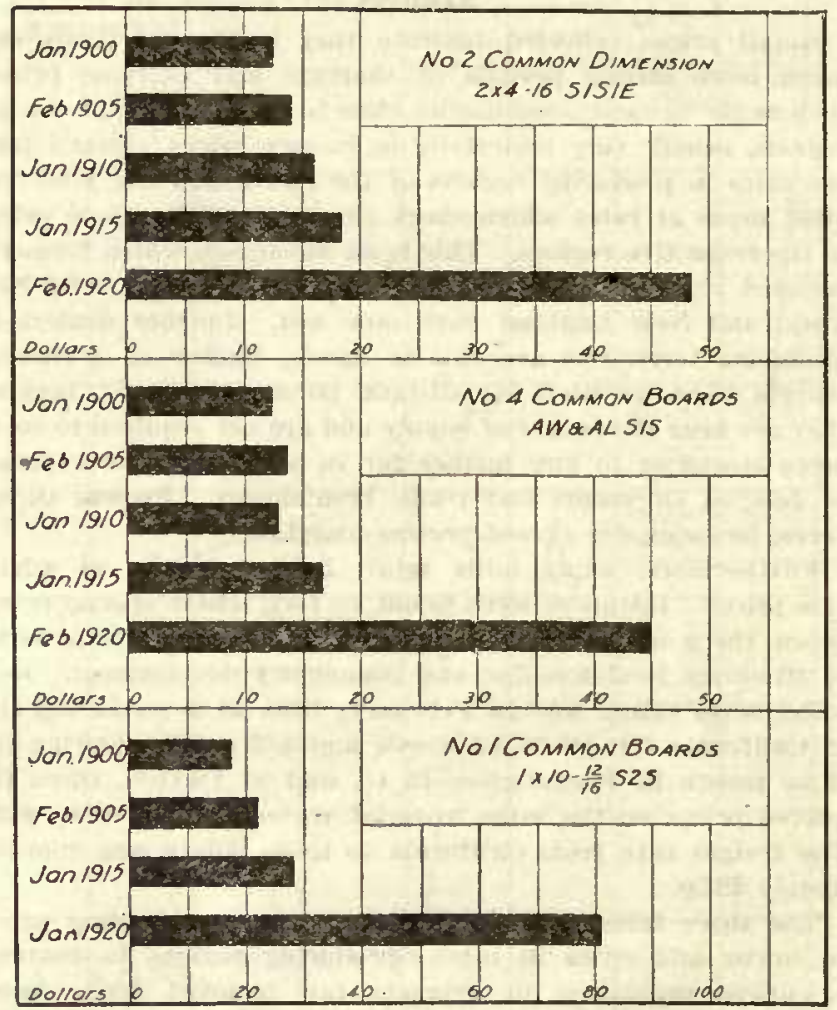

F1a. 17.-Wholesale prlces at Minneapolis of northern pine lumber.

The total cost of producing lumber in the region west of the Cascades, in Washlngton and Oregon, in 1919, based on information collected and complled by the West Coast Lumbermen's Association, but presented below in a ilttle different form, and compared with other data showing average costs and mill price for 1913 , is as follows:

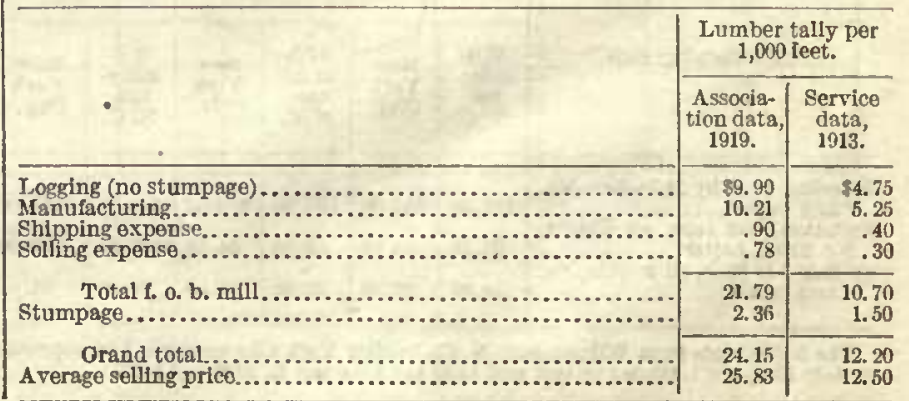



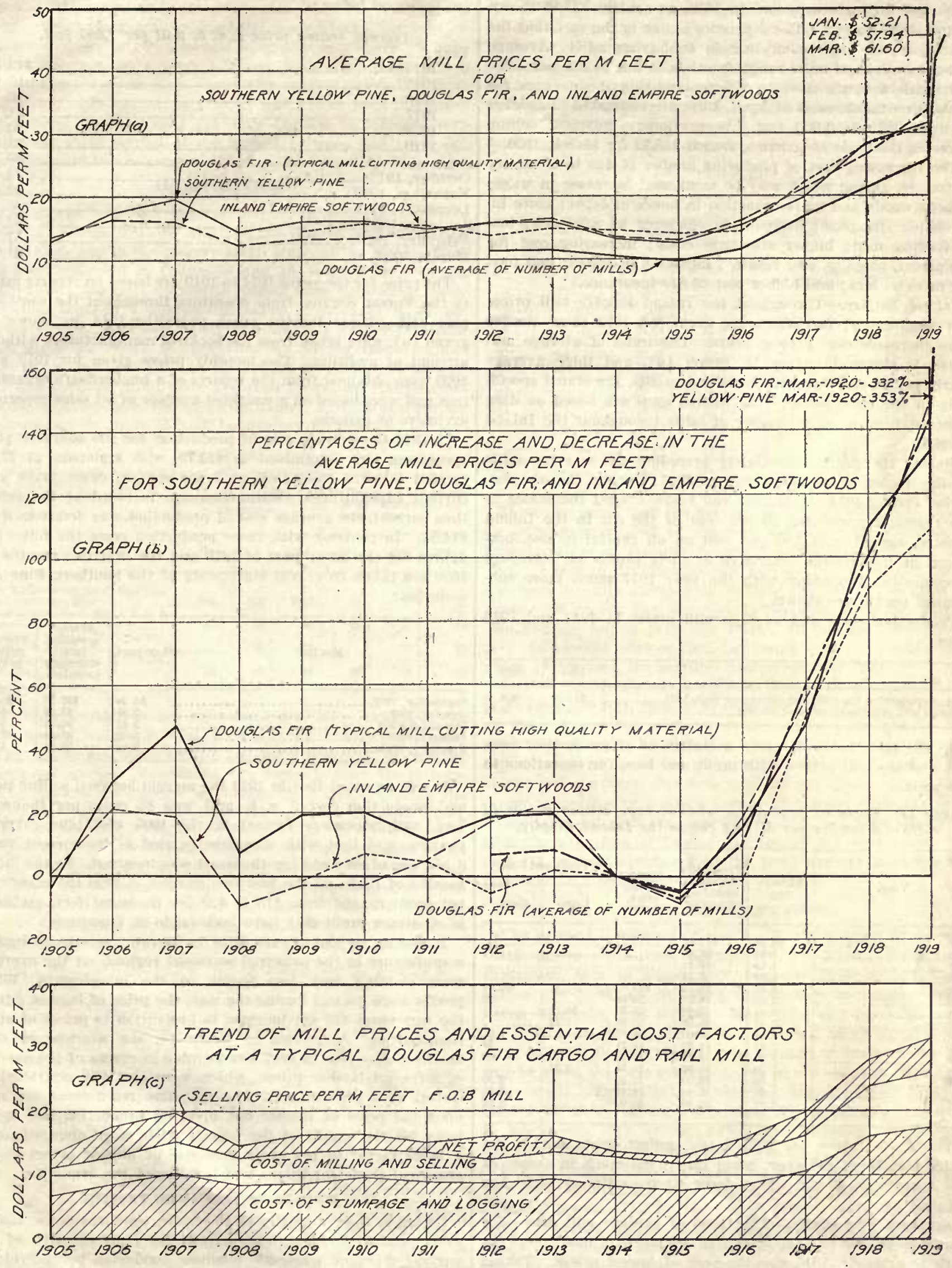

FIG. 18. 
The association's compilation sliows that it cost $\$ 24.95$ per 1,000 fect to produce lumber in 1919 , as against $\$ 24.15$ shown by the above figures. The difference is due to the fact that the figures of the assoclation include log-buying mills. Average costs at individual mills range from about $\$ 1 \$$ to $\$ 32$ per 1,000 feet, with a figure close to $\$ 25$ representing the average for 1919. Production costs of April, 1920, are estimated to average at least $\$ 26$ per 1,000 feet. As previously indicated selling prices on the basis of orders averaged $\$ 45.72$ for M1arch, 1920 .

The Increasing cost of producing lumber is due to a variety of factors, among which may be mentioned increases ln wages in hoth woods and mill; reduction in hours of labor; more inaccessible stumpage; decrease in efficiency of workmen; loss in fecding men; higher stumpage costs; increasing cost for equipment, supplies, and repairs; increases in freight and towing rates on $\operatorname{logs}$; and higher cost of fire insurance.

Inland Empire.-Throughout tỉe Inland Empire mlll prices and logging and manufacturing costs for $1919^{\circ}$ show similar large increases over prewar years. The trend of average mill prices is shown in figure $18, \operatorname{graph}(a)$, and these average yearly prices, together with costs and profits, are stated specifically in the table below. The figures used are based on data collected from a large number of mills throughout the Inland Empire.

During the years immediately preceding the war the mllls in the region show small net profits. During the six-year period ending 1914 the largest and best-managed companies in the region, representing 59 per cent of the cut in the Inland Empire, earned only 1.06 per cent on all capital in use, borrowed or unborrowed, exclusive of their profits on stumpage investments. Beginning with the year 1917 much more substantial profits are shown.

Production costs and average mill prices in 1914 and 1919 were:

\begin{tabular}{|c|c|c|}
\hline 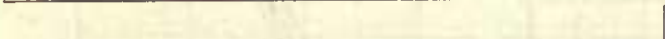 & 1914 & 1919 \\
\hline $\begin{array}{l}\text { Cost of productlon per } 1,000 \text { feet (stumpage included) ... } \\
\text { A verage mill price received per } 1,000 \text { feet...................... }\end{array}$ & $\$ 14.54$ & $\begin{array}{r}\$ 28.40 \\
30.92\end{array}$ \\
\hline
\end{tabular}

In the table below is given a statement of production costs and average mill prices, with profit and loss, for operations in the region.

TABIE 17.-Costs of production and average selling prices of softwood lumber per $M$ feet cut in the Inland Empire.

\begin{tabular}{|c|c|c|c|c|c|c|}
\hline & \multirow{2}{*}{ Year. } & \multirow{2}{*}{$\begin{array}{l}\text { Stump- } \\
\text { age. }\end{array}$} & \multirow{2}{*}{$\begin{array}{l}\text { Production } \\
\text { costs, } \\
\text { including } \\
\text { stumpage. }\end{array}$} & \multirow{2}{*}{$\begin{array}{l}\text { Average } \\
\text { selling } \\
\text { prlce. }\end{array}$} & \multicolumn{2}{|c|}{ Profit and Ioss. } \\
\hline & & & & & Loss. & Gain. \\
\hline \multirow{2}{*}{\multicolumn{2}{|c|}{$\begin{array}{l}1905 . \\
1906 .\end{array}$}} & $\$ 0.94$ & $\$ 11.32$ & & & \\
\hline & & 1.06 & 11.49 & & & 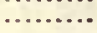 \\
\hline \multicolumn{2}{|l|}{$\begin{array}{l}1906 . \\
1907 . \\
1909\end{array}$} & 1.15 & 14. 24 & & & .......... \\
\hline \multicolumn{2}{|l|}{$\begin{array}{l}1908 . . \\
1909 . .\end{array}$} & $\begin{array}{l}1.59 \\
3.22\end{array}$ & $\begin{array}{l}13.38 \\
14.19\end{array}$ & $\$ 14.62$ & & 50.43 \\
\hline \multirow{2}{*}{\multicolumn{2}{|c|}{$\begin{array}{l}1910 . . \\
1911 .\end{array}$}} & 3.00 & 14.78 & 15.38 & & .60 \\
\hline & & 2.91 & 15.68 & 15.50 & $\$ 0.18$ & \\
\hline & 2.67 & 15.18 & 13.96 & 1.22 & \\
\hline \multirow{2}{*}{\multicolumn{2}{|c|}{$\begin{array}{l}1913 \ldots \\
1914 \ldots\end{array}$}} & 2.21 & 15.00 & 15.07 & $\ldots \ldots \ldots \ldots$ & .07 \\
\hline & & 2.32 & 14.54 & 14.81 & .............. & .27 \\
\hline \multicolumn{2}{|l|}{$1915 .}$. & 1.50 & $\begin{array}{l}14.20 \\
16.90\end{array}$ & $\begin{array}{l}14.12 \\
14.56\end{array}$ & T34 & .08 \\
\hline \multicolumn{2}{|l|}{ 1916.. } & $\begin{array}{l}1.70 \\
1.80\end{array}$ & $\begin{array}{l}16.90 \\
19.70\end{array}$ & $\begin{array}{l}14.00 \\
22.20\end{array}$ & & \\
\hline \multirow{2}{*}{\multicolumn{2}{|c|}{$\begin{array}{l}1917 \ldots \\
1918 . \\
1919 .\end{array}$}} & 1.90 & 25.40 & 28.15 & & 2.75 \\
\hline & & 2.00 & 28.40 & 30.92 & & 2.52 \\
\hline
\end{tabular}

The figures given for 1919 do not reflect prices during the iatter months of the year, when they were much in excess of the arerage of $\$ 30.92$. They have since continued at higher points.

Southern pine States.-The trend of average mill prices for southern yellow plne is shown in graph $(a)$, figure 18 . As with Douglas fir, 1915 was the year of lowest prices. Taking 1914 us a more ncarly arerage prewar year, the selling price was $\$ 13.68$, as against $\$ 33.94$ for 1919 , an tncrease of approxi- mately 150 per cent. The average mill prices from 1914 to date are indicated below:

Year:

$$
\text { Average selling price } f \text {. } 0 \text {. b. mill per } 1,000 \text { feet. }
$$

1914

作 $\$ 13.68$

1915

$1916 \ldots$

1917

$1918 \ldots$

1919

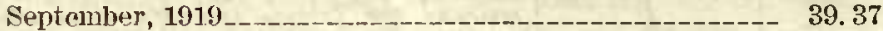

October, 1919

November, 1919

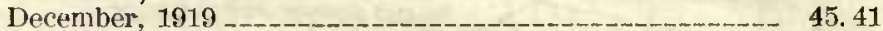

January, $1920 \ldots$

February, 1920_... 57.94

March, 1920

The price for the years 1914 to 1919 are based on reports made to the Forest Service from operators throughout the southern pine belt. 'Those for the years preceding 1914, as shown in graph $(a)$, were taken from the books of manufacturers without attempt at auditing. The monthly prices given for 1919 and 1920 were obtained from the reports of a lumbermen's organization and were based on a weighted average of all sales reported, exclusive of exports.

In 1914 the average cost of production for 108 southern pine operations was determined as $\$ 12.79$, with stumpage at $\$ 2.36$ carried forward from 1905 at 1 per cent to cover taxes and current expenditures. WIth stumpage included at the prices then current, the average cost of production was determined as $\$ 14.54$. In contrast with these production costs the following figures for the latter part of 1919 and the first two months of 1920 are taken from cost statements of the Southern Pine Association:

\begin{tabular}{|c|c|c|c|}
\hline Month. & Stumpage. & $\begin{array}{l}\text { Average } \\
\text { operating } \\
\text { cost, } \\
\text { stumpage } \\
\text { lncluded. }\end{array}$ & $\begin{array}{l}\text { A rerage } \\
\text { selling } \\
\text { price. }\end{array}$ \\
\hline 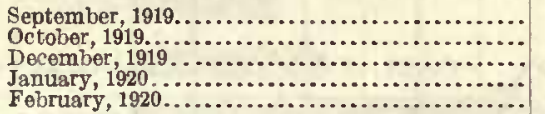 & $\begin{array}{r}55.24 \\
5.31 \\
5.41 \\
5.52 \\
5.44\end{array}$ & $\begin{array}{r}\$ 26.56 \\
27.04 \\
31.75 \\
29.14 \\
23.54\end{array}$ & $\begin{array}{r}\$ 39.37 \\
44.60 \\
45.41 \\
52.51 \\
57.94\end{array}$ \\
\hline
\end{tabular}

It will be noted that in 1914 the margin betwcen selling price and production cost f. o. b. mill was 89 cents per thousand feet, with stumpage figured at the 1905 cost plus carrying charges, and that with stumpage carried at its current value a net loss of 86 cents per thousand was incurred. In the latter months of 1919 and the first two months of 1920 the margin of net profit ranged from $\$ 13$ to $\$ 29$ per thousand feet, exclusive of whatever profit may have been made on stumpage.

In the six or eight years prior to the war, returns in lumber manufacture in the principal softwood regions, on the average, were yielding very low profits on the investments. While profits were greater during the war, the price of lumber during the war years did not increase in proportion to prices of other commodities. As shown in figure 13, the average of com. modity prices rose in 1917 considerable in excess of the average of softwood lumber prices, which were partlally restricted by Government price fixing. The war-time restrictions not only upon the price of lumber but upon Its productlon and movement for the supply of the normal trade were unquestionably a large factor in the quick response of lumber prices to the abnormal trade condlions whlch followed the armistice.

\section{WHOLESALE COSTS AND PROFITS.}

Owing to the complexity of the trade, time was not available to determine average costs and profits representative of the varlous types of wholesale business conducted by lndividuals and organizatlons not attached to mill organizations. The mill prices given are based on sales made by the larger mills 
to retailers, wholesale dealers, and wholesale consumers. While a few of the larger mills do not sell to wholesale dealers, the more general practice is to grant the wholesalers a cliscount on the prices made to retailers and wholesale consumers. Wholesalers, however, do a large business with small mills which are usually not in as close touch with market prices and from which they often obtaln much lower prices than from the larger and stronger mills. They are tlus enabled to increase very materially their portion of the margin between mill prlce and the price paid by the consumer.

TRANSPORTATION.

The extent to which the growing distnnce between forests and markets has steadily adder to the cost of lumber in eastern markets and in the country retail trade of the Middle West has been lndicated in figures 13 and 15 , respectively. In the years before the more accessible forests were exhausted, transportation imposed a charge equivalent to from $\$ 1$ to $\$ 3$ per thousand feet. The cost to-day of inporting lumber into New York from the South is approximately $\$ 9$ per thousand and from the West Coast $\$ 20$. An idea of the percentage of the prewar and postwar retail plice absorbed by transportation costs can be obtained from the following table. Freight charges are computed on the basis of 2,500 pounds per 1,000 feet:

TABLE 18.

\begin{tabular}{|c|c|c|c|c|c|c|}
\hline & \multicolumn{3}{|c|}{$\begin{array}{l}\text { Retail prices per } \\
\text { thousand. }\end{array}$} & \multicolumn{3}{|c|}{$\begin{array}{l}\text { Percentage of retail } \\
\text { price absorbed by } \\
\text { freight rates. }\end{array}$} \\
\hline & 1914 & 1019 & 1920 & 1914 & 1919 & 1920 \\
\hline $\begin{array}{l}\text { New York-Douglas fir flooring, } \\
\text { No. } 2 \text { clr. ver. grain............. }\end{array}$ & $\$ 62$ & $\$ 86$ & $\$ 140$ & 31 & 23 & 14 \\
\hline $\begin{array}{l}\text { Plttsburgh-Soutbern p i in } \\
\text { boards, No. } 2 \text { com., } 1 \text { \% } 8 . . . . . .\end{array}$ & 32 & 36 & 80 & 28 & 25 & 11 \\
\hline $\begin{array}{l}\text { Chicago-Douglas fir flooting, } \\
\text { No.2 elr. ver. grain............. }\end{array}$ & & 73 & 112 & & 20 & \\
\hline 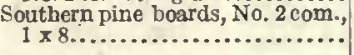 & 22 & 49 & 66 & 35 & 16 & 12 \\
\hline
\end{tabular}

Although transportation costs have gradually increased, the table shows strikingly how present prices have outstripped freight increases made during and since the war, on specific grades and species. The table below serves to show the increasing transportation charges on lumber into Chicago, from the ditys when the forests were accessible to water transportation, as all rail shipments became necessary with the cutting out of the accessible forests. To-any the average freight charge on all lumber going into Chicago is probably between $\$ 10$ and $\$ 11$ per 1,000 feet, due to the increasing volume of western lumber which hus entered the market during the past 12 or 18 montlis. On the basis of the present average retail price this would be equivalent to 12 to 13 per cent, as against about 20 per cent in 1912-1915.

TABLE 19.-Transportation ${ }^{1}$ per Mf board feet on lumber to Chicago.

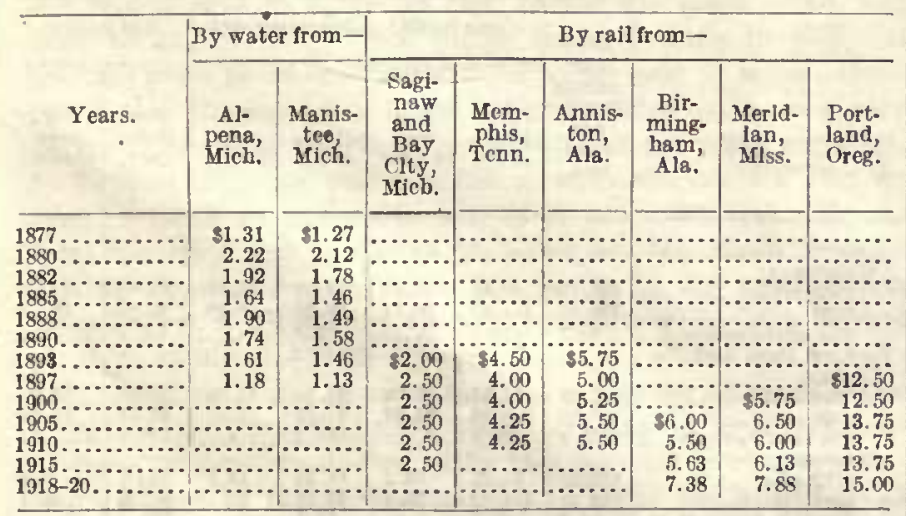

1 Transportation by water based on weekly rates published by the Nortbwest Lum. berman; rail rates computed on basis 2,500 pounds per M. feet.
In southern Minnesota it was possible to determine quite closely from the purchase records of a number of large line yard companies the average transportation cost carricd by the lumber distributed through thelr retail yards. These steadily increasing costs, shown in the table below, are primarily due to the increasing volume of western lumber which these companies have had to import in order to supply the needs of their territory, which only a few years ago was Immedlately contiguous to the greatest lumber-prorlucing reglon in the country.

TAILE 20.

\begin{tabular}{|c|c|c|c|c|c|c|c|}
\hline & \multirow[t]{2}{*}{ Ycars. } & \multicolumn{2}{|c|}{$\begin{array}{l}\text { A verage retail sell- } \\
\text { ing price. }\end{array}$} & \multicolumn{2}{|c|}{$\begin{array}{l}\text { A verage transporta- } \\
\text { tion cost. }\end{array}$} & \multicolumn{2}{|c|}{$\begin{array}{l}\text { Portion of average } \\
\text { retail selling price } \\
\text { a b o o b b b by } \\
\text { transportation. }\end{array}$} \\
\hline & & $\begin{array}{c}\text { Per } \\
\text { thousand. }\end{array}$ & $\begin{array}{l}\text { Per cent } \\
\text { increase. }\end{array}$ & $\begin{array}{c}\text { Per } \\
\text { thousand. }\end{array}$ & $\begin{array}{l}\text { Per cent } \\
\text { increase. }\end{array}$ & Per cent. & $\begin{array}{l}\text { Per cent } \\
\text { increase. }\end{array}$ \\
\hline & $\$ 2$ & & & 0 & 12.5 & \\
\hline \multirow{2}{*}{\multicolumn{2}{|c|}{$\begin{array}{l}1906 . \\
1907 . .\end{array}$}} & & & & & & \\
\hline & & & & & & & \\
\hline \multirow{2}{*}{\multicolumn{2}{|c|}{$\begin{array}{l}1908 \ldots \ldots \ldots \ldots \ldots \ldots \ldots \\
1909 \ldots \ldots \ldots \ldots \ldots \ldots\end{array}$}} & & & & & & \\
\hline & & & & & & & 17.6 \\
\hline \multicolumn{2}{|c|}{$\begin{array}{l}1909 \ldots \ldots \ldots \ldots \ldots \ldots \ldots \ldots \\
1910 \ldots \ldots \ldots \ldots \ldots \ldots \ldots\end{array}$} & & & & & & \\
\hline \multicolumn{2}{|c|}{$1911 \ldots \ldots \ldots \ldots \ldots \ldots$} & & & & & & \\
\hline \multirow{2}{*}{\multicolumn{2}{|c|}{$\begin{array}{l}1912 \ldots \ldots \ldots \ldots \ldots \ldots \\
1913, \ldots \ldots \ldots \ldots \ldots\end{array}$}} & & & & & & \\
\hline \multirow{2}{*}{\multicolumn{2}{|c|}{$\begin{array}{l}1913 \ldots \ldots \ldots \ldots \ldots \ldots \ldots \\
1914 \ldots \ldots \ldots \ldots \ldots \ldots\end{array}$}} & & & & & & \\
\hline & & & 22. 2 & & 146.0 & & 100.8 \\
\hline \multicolumn{2}{|r|}{ (...................... } & & & & & & 132.2 \\
\hline \multicolumn{2}{|r|}{. } & & $\begin{array}{l}20.7 \\
48.0\end{array}$ & 8 & $\begin{array}{l}5 \\
0\end{array}$ & & $\begin{array}{l}91.2 \\
66.4\end{array}$ \\
\hline & 46. & 78.6 & & 231.0 & & \\
\hline \multicolumn{2}{|r|}{ (1, } & 54.42 & 109.0 & 11.75 & 262.0 & 21.6 & 72.8 \\
\hline
\end{tabular}

It will be noted that the average selling price for 1919 shows an increase over 1903 of 109 per cent, while the increase in transportation in relation to selling price was only 72.8 per cent. Altbough transportation's portion of the selling price has been steadily growing in dollars and cents, the price of lumber during the past three years has been increasing faster. The average selling price for March, 1920, was 230 per cent over the average price of 1905 , but transportation absorbed only about 14 per cent, the smallest percentage since 1908 .

In 1905 northern plne, shipped on freight rates of from $\$ 2.50$ to $\$ 3$ per 1,000 feet, formed 80 to 90 per cent of the retail stock of these companies, while western timber amounted to less than 20 per cent. In 1919 these percentages were almost reversed, western timber forming practically 80 per cent of the stocks and northern pine less than 20 per cent. Owing to a larger proportion of western lumber in these stocks this year, it is estimated that the average freight cost represented by each thousand feet of lumber distributed will be between $\$ 12$ and $\$ 13$, almost equivalent to the total average lumber price of $\$ 16$ in that region 25 years ago.

\section{RETAIL PRICES AND COSTS.}

The upuard movement of prices.-The movement of average retail prices in country districts in the Middle West from September, 1918, to March, 1920, is shown in figure 19. These values are based on line-yard distribution in Kansas, Oklahoma, Nebraska, and southern Minnesota, and represent average selling prices for lumber only, arrived at by dividing the total sales in dollars by the total feetage of lumber sold. It will be noted that the average prices in the above regions coinclde closely. From 1912 to 1915 the average retall price of lumber in these regions was around $\$ 30$ to $\$ 32$ per thousand. In September, 1918, average prices were between $\$ 40$ and $\$ 50$, and moved upward to about $\$ 85$ in March, 1920.

In the larger cities of the region, such as Chicago, Kansas City, and Minneapolis, there was a simllar upward movement of retail prices. During the period 1912 to 1914 the average selling price of lumber in Chicago, Kansas City, and Minneapolis was close to $\$ 26$ per 1,000 feet. There was little variation between the cities. The average seling price in 1919 in Kansas City centered between $\$ 45$ and $\$ 50$ per thousand. Arerage prices of March, 1920, were variously estimated by 
retailers in Kansas Clty and Chicago to be from $\$ 75$ to $\$ 80$ per 1,000 feet, a few dollars less than the average shown for country trade.

Prewar and postwar changes in wholesale and retail prices of specific softwood grades and species at various points throughout the country are indicated in Table 21. It should he explained that the margins shown between wholesale and retail values do not always accurately represent the actual margins, since the material sold in any given month may have

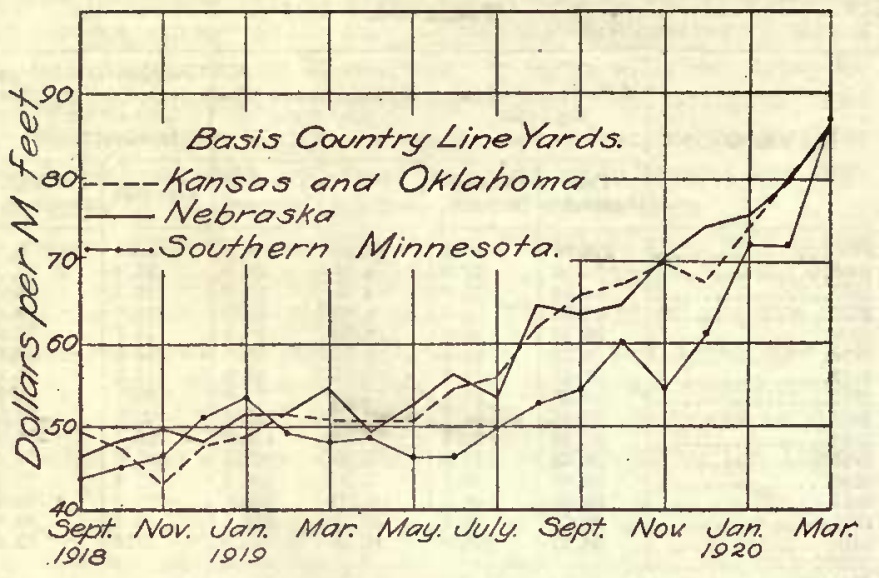

Fia. 19.-Comparlson of trend of regional retail lumber values. (Based on averages of monthly sales.)

been purchased months before. The margin varies with grades and species, retailers figuring a lower gross profit margln in the handling of common grades sold in large volume at a relatively rapid rate of turnover than for higher grades and special woods. The expense of handling hardwoods is, of course, much greater than for softwood lumber. For softwoods the margln on upper grades ranges from zero or a few dollars per thousand at or near mill points to $\$ 45$ or $\$ 50$ in New York City, wllle for hardwoods, especially the upper grades, spreads as high as $\$ 80$ are of record.

Table 22 compares average selling prices of lumber distributed through line yards in the Middle West, in March, 1920, with the selling prices in the period 1912 to 1915, and also with the selling prices In April, 1919, when prices began to ascend sharply.

TABLE 21.-Wholesale and retail prices of Douglas fir and southern yellow pine lumber at various points throughout the United states.

\begin{tabular}{|c|c|c|c|c|c|c|}
\hline \multirow{2}{*}{ Douglas fir. } & \multicolumn{3}{|c|}{$\begin{array}{l}\text { Wholesale prices (dollars } \\
\text { per II feet). }\end{array}$} & \multicolumn{3}{|c|}{$\begin{array}{l}\text { Retail prices (dollars } \\
\text { per M feet). }\end{array}$} \\
\hline & $\begin{array}{c}\text { Septem- } \\
\text { ber, } \\
1918 .\end{array}$ & $\begin{array}{l}\text { Febru- } \\
\text { ary, } \\
1919 .\end{array}$ & $\begin{array}{c}\text { Febru- } \\
\text { ary, } \\
1920 .\end{array}$ & $\begin{array}{l}\text { Septem- } \\
\text { ber, } \\
1918 .\end{array}$ & $\begin{array}{c}\text { Febru- } \\
\text { ary, } \\
1919 .\end{array}$ & $\begin{array}{c}\text { Febru- } \\
\text { 8ry, } \\
1920 .\end{array}$ \\
\hline 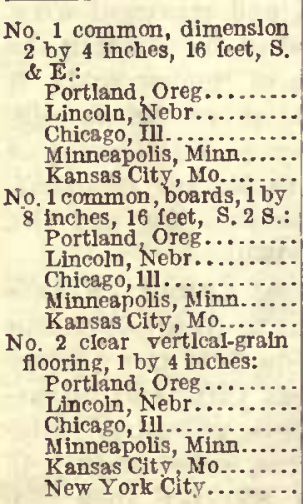 & $\begin{array}{r}120.00 \\
51.00 \\
\cdots 46.00 \\
49.00 \\
150.00\end{array}$ & $\begin{array}{r}18.50 \\
30.50 \\
31.50 \\
30.00 \\
31.10 \\
\\
18.50 \\
31.50 \\
37.50 \\
39.00\end{array}$ & $\begin{array}{r}86.75 \\
103.60 \\
95.00 \\
98.00 \\
112.15 \\
111.50\end{array}$ & $\begin{array}{l}\because 68.33 \\
73.00 \\
56.00 \\
56.60 \\
62.50\end{array}$ & $\begin{array}{l}80.00 \\
73.00 \\
58.00 \\
58.50 \\
86.00\end{array}$ & $\begin{array}{r}86.75 \\
112.50 \\
111.65 \\
117.00 \\
128.35 \\
139.50\end{array}$ \\
\hline
\end{tabular}

$\mathrm{TABLF}$ 21.-Wholesale and retail prices of Douglas fir and southern yellow pine lumber, etc.-Continued.

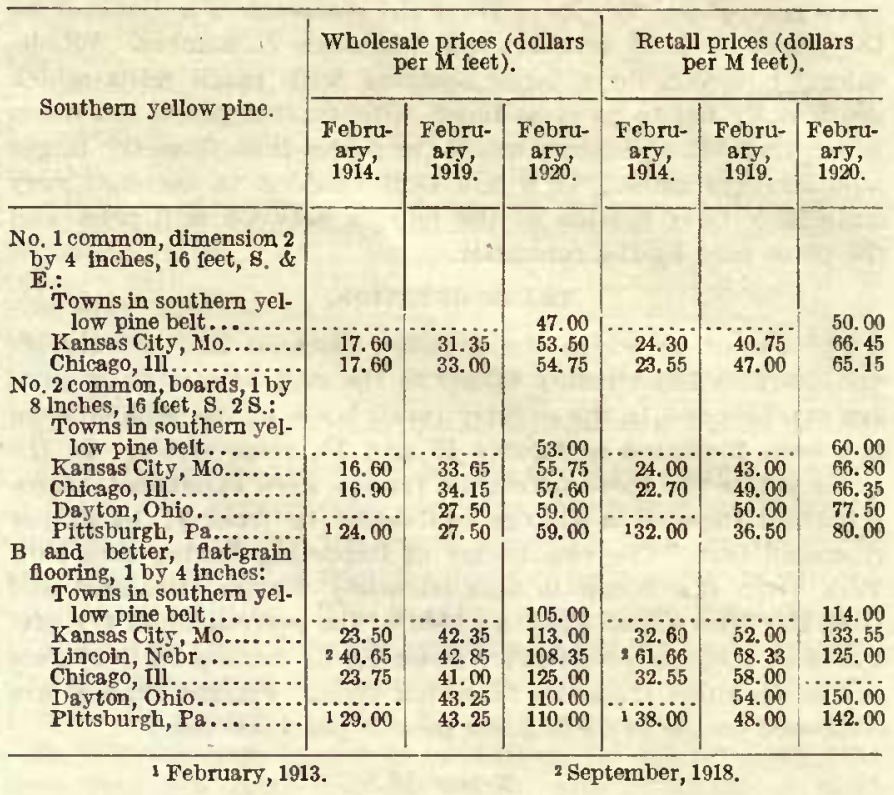

TABLE 22.-Comparison of average retail prices per 1,000 fect in various regions and times.

\begin{tabular}{|c|c|c|c|}
\hline 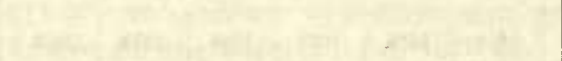 & $\begin{array}{l}\text { April, } \\
1919 .\end{array}$ & $\begin{array}{c}\text { March, } \\
1920 .\end{array}$ & $\begin{array}{l}\text { Per cent } \\
\text { Increase. }\end{array}$ \\
\hline 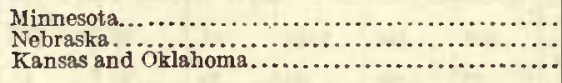 & $\begin{array}{r}\$ 48.75 \\
49.20 \\
50.81\end{array}$ & $\begin{array}{r}\$ 86.76 \\
85.86 \\
85.65\end{array}$ & $\begin{array}{l}78.0 \\
74.5 \\
68.5\end{array}$ \\
\hline t & $\begin{array}{l}\text { Period } \\
1912 \text { to } \\
1915 .\end{array}$ & $\begin{array}{c}\text { March, } \\
1920 .\end{array}$ & $\begin{array}{l}\text { Per cent } \\
\text { increase. }\end{array}$ \\
\hline 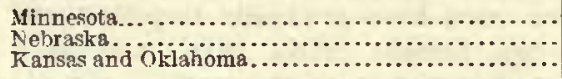 & $\begin{array}{r}\$ 31.24 \\
31.29 \\
29.73\end{array}$ & $\begin{array}{r}\$ 85.76 \\
85.86 \\
85.65\end{array}$ & $\begin{array}{l}177.5 \\
174.5 \\
188.0\end{array}$ \\
\hline
\end{tabular}

Changing values in country retall distribution are further shown specifically in Tables 23 and 24, and graphlcally in figures 20 and 21. A comparison of essential cost factors In the average price of lumber in a large Middle Western city ls indicated in figure 22. The average buying prices shown in Table 24 include freight.

TABLE 23.-Comparison of costs and profits of retail lumber distribution in 1912-1915 and 1919.

\begin{tabular}{|c|c|c|c|c|c|c|c|}
\hline & \multicolumn{7}{|c|}{ Country trade. } \\
\hline & \multirow{2}{*}{$\begin{array}{l}\text { A ver- } \\
\text { age } \\
\text { selling } \\
\text { price } \\
\text { per } \\
1,000 \\
\text { leet. }\end{array}$} & \multicolumn{2}{|c|}{ Gross profit. } & \multicolumn{2}{|c|}{ Oporating cost. } & \multicolumn{2}{|c|}{ Net profit. } \\
\hline 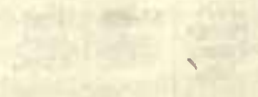 & & $\begin{array}{l}\text { Per } \\
\text { thoul- } \\
\text { sand. }\end{array}$ & $\begin{array}{c}\text { Per } \\
\text { cent } \\
\text { of sales. }\end{array}$ & $\begin{array}{l}\text { Per } \\
\text { thoul- } \\
\text { sand. }\end{array}$ & $\begin{array}{c}\text { Per } \\
\text { cent } \\
\text { of sales. }\end{array}$ & $\begin{array}{l}\text { Per } \\
\text { thout- } \\
\text { sand. }\end{array}$ & $\begin{array}{c}\text { Per } \\
\text { cent } \\
\text { of sales. }\end{array}$ \\
\hline \multicolumn{8}{|l|}{$\begin{array}{l}\text { MIssouri, Kansas, and } \\
\text { Oklahoma: }\end{array}$} \\
\hline & $\$ 29.73$ & 57.07 & 23.79 & & 16.77 & 82.08 & \\
\hline & 856,00 & $\$ 14.86$ & 26.54 & $\$ 9.05$ & 16.16 & $\$$ & 10.38 \\
\hline $\begin{array}{l}\text { Per cent increase.... } \\
\text { Western Iowa and }\end{array}$ & & .1 & & & & & \\
\hline $\begin{array}{l}\text { rask } \\
191 \\
1011\end{array}$ & $\$ 31$ & & 1 & $\$ 4.33$ & 13.85 & $\$ 2.84$ & \\
\hline & $\$ 57.30$ & $\$ 13.88$ & 24.22 & 87.33 & 12.79 & $\$ 6.55$ & 11.43 \\
\hline $\begin{array}{l}\text { Per cent is } \\
\text { innesota: }\end{array}$ & & & & & & & \\
\hline $\begin{array}{l}1912-1915 . . \\
1019 \ldots \ldots\end{array}$ & 831.24 & 57.25 & 23.2 & $\$ 4.24$ & 13.5 & 83.01 & 9.6 \\
\hline Per & 74.2 & 97.7 & & 68.6 & & 138.5 & \\
\hline
\end{tabular}


'TABLE: 24.-Costs and profits of retail lumber distribution by ycars 1905-1919, country trade, IIinnesota.

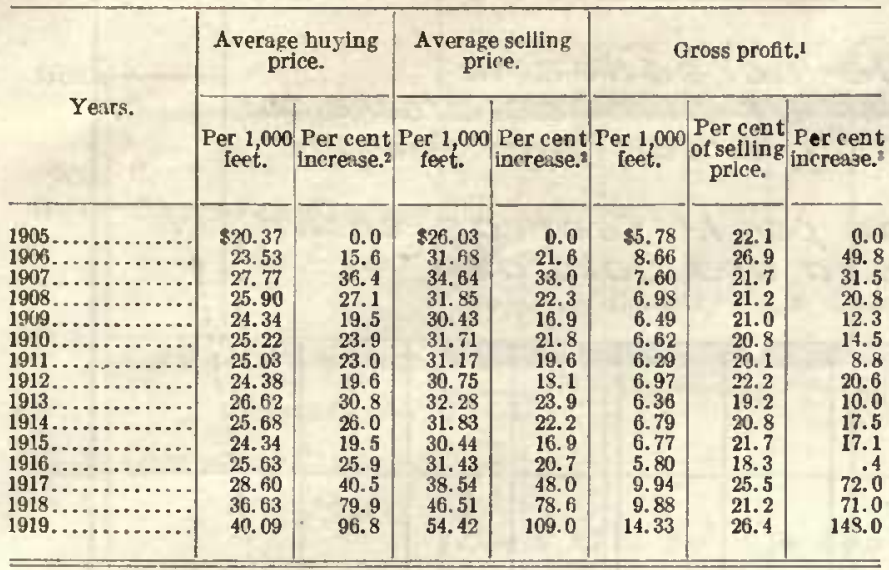

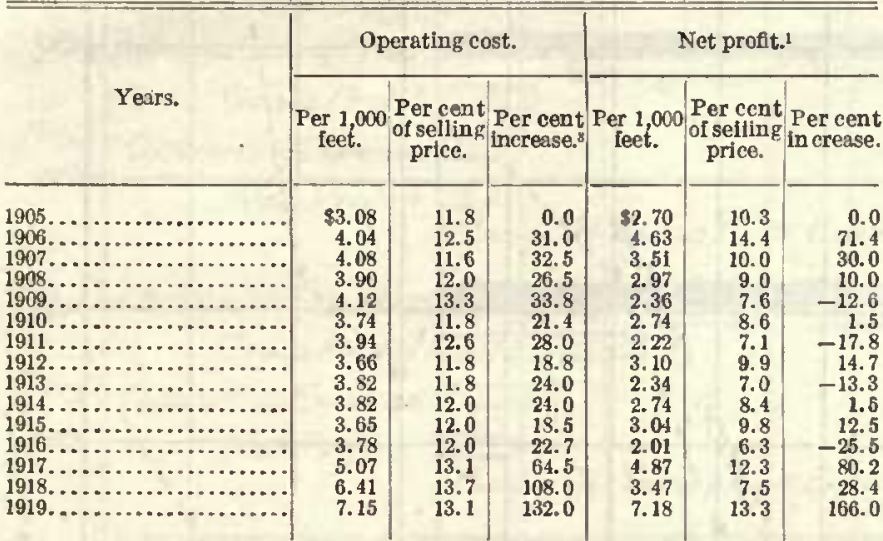

2 The number of companies from whose records flgures are taken varies somewhat, so that the gross profit shown in tbe tabie is not in ail cases the exact difference between huying price and seiling price, nor net profit the exact difference between gross profits and operating costs.

2 Per cent increase figured on 1905 values as base.

- Per 1,000-foot vaiues.

Distribution of price increase.-As has been pointed out, the average retali price of lumber in 1919 in the country trade of the Prairie States was about $\$ 25$ higher than in the period 1912-1915. For the yards covered in Minnesota the exact increase was $\$ 23.17$. Of this increase the manufacturer and wholesaler took $\$ 11.34$, or approximately 50 per cent, the railroads $\$ 4.75$, or 20 per cent, and the retallers $\$ 7.08$, or approximately 30 per cent. Of the retallers' portion, $\$ 2.91$, or 12 per cent of the total increase, was absorbed in increased cost of retaii distribution.

Retail profits.-From Table 23 it will be noted that retail operating expenses and net profits figured on percentage of business done had not changed greatiy over those shown for the period 1912 to 1915 . In that period the gross profit was close to 23 per cent in the region covered, while In 1919 the average gross profit centered around 25 per cent of sales. Computed on a thousand-foot basis, however, there has been a very decided change in margin of net profit and operating expenses. In 1912 to 1915, for example, the average net profit shown by country yards in Minnesota was $\$ 3.01$ per 1,000 feet, and the total operating cost was $\$ 4.24$ per 1,000 feet. In 1919 the average net profit shown by over 100 yards in the same reglon amounted to $\$ 7.18$ and the operating costs to $\$ 7.15$, or a margin of gross profit of $\$ 14.33$.

It should be borne in mind that the net profit shown includes a certaln percentage of book profit, or gain on Inventory, due to the risiug prices during 1919. Actual cash profits are fur. ther reduced by the Income taxes, which are not figured in as operating expenses. These taxes, of course, vary with the com- panies and profits shown. In the case of a representative company which operates a llne of some 40 or 50 yards the net profit, including gain on inventory after Income taxes had been paid, was about $\$ 4.75$ per 1,000 feet. A portion of the manufacturers' increase was likewise absorbed by increased costs of production and operations.

As previously shown, average retail selling prices for the Middle West, which were from $\$ 30$ to $\$ 32$ In 1912-1915, advanced to about $\$ 56$ in 1919 and to about $\$ 86$ in March, 1920. Buylng prices averaged about $\$ 25$ in 1912-1915, advanced to about $\$ 40$ in 1919, and in March, 1920, were still blgher. Retail operating costs increased from about $\$ 4.50$ In $1912-1910$ to about $\$ 7.85$ in 1919 , and to about $\$ 8$ in March, 1920.

\section{LUMBER PRICES UNJUSTIFIED BY PRODUCTION AND DISTRIBU-} TION COSTS.

A study of prices and increased production and distribution costs durlng the prewar and postwar periods substantiates the statements made by many lumbermen that prices during the end of 1919 and the beginning of 1920 reached points unjustified by production and distributing costs. While present prices are somewhat below the March level they are stlll in excess of prices justified by increased production costs and falr profits. The following is believed to be a liberal approximatlon of costs entering into the average retall price of lumber as determined for March, 1920, in the country trade in the Middle West. The lumbernen's figures on production costs, which may be considered outside costs, are accepted as a basls. The production cost is a weighted average computed from the relative per cents of varlous species in tile retail stocks handled.

TABLE 25.-Approximate production and distributing cost, Ifarch, 1920, per thousand feet of lumber.

Lumber productiou (stumpage and selling costs included) Transportation (mill to retril yards)

Retail distribution

Total - $\frac{86.50}{80}$

Average retail selling price March, 1920_.

Margln of profit (includes interest on investment) _._._- 39.50

The margin of profit indicated exceeds by $\$ 8$ to $\$ 10$ the total arerage retail sellng price for the lumber sold in the same region luring the 1912-1915 period, whlch included all costs and profits of manufacture and distribution. Irrespective of the distribution of this excessive profit, which, by and large, has unquestionably varied with relative advantages held and with relative abilities to domlnate sltuations, lumber prices are excessive and yield profits bearing no reasonable relation to increased costs of lumber production and distribution.

That prices went unreasonably and unfortunately high is readily admitted by many of the more responsible and farseeing men in the trade, and is concretely evidenced by the efforts of numerous large companies to stabilize prices during December, 1919, and January and February of 1920, by action on the part of retail lumber dealers calling upon manufacturers to stabilize lumber prices, and by editorial comment in lumber journals. The following is an extract from a published letter, written by the secretary-manager of a large lumbermen's association in response to a letter from the secretary of a retallers' association, suggesting that prices be stabilized untii July 1 at least:

I am not violating any conflence when I say to you that the situation has given the lumber manufacturers much concern, many having expressed themselves as deploring the fact that prices have been bld up to present flgures hy the huyers themseives. It is a little too much of a strain on human nature to expect that producers shall refune to accept the highest prices offered for their goods. 


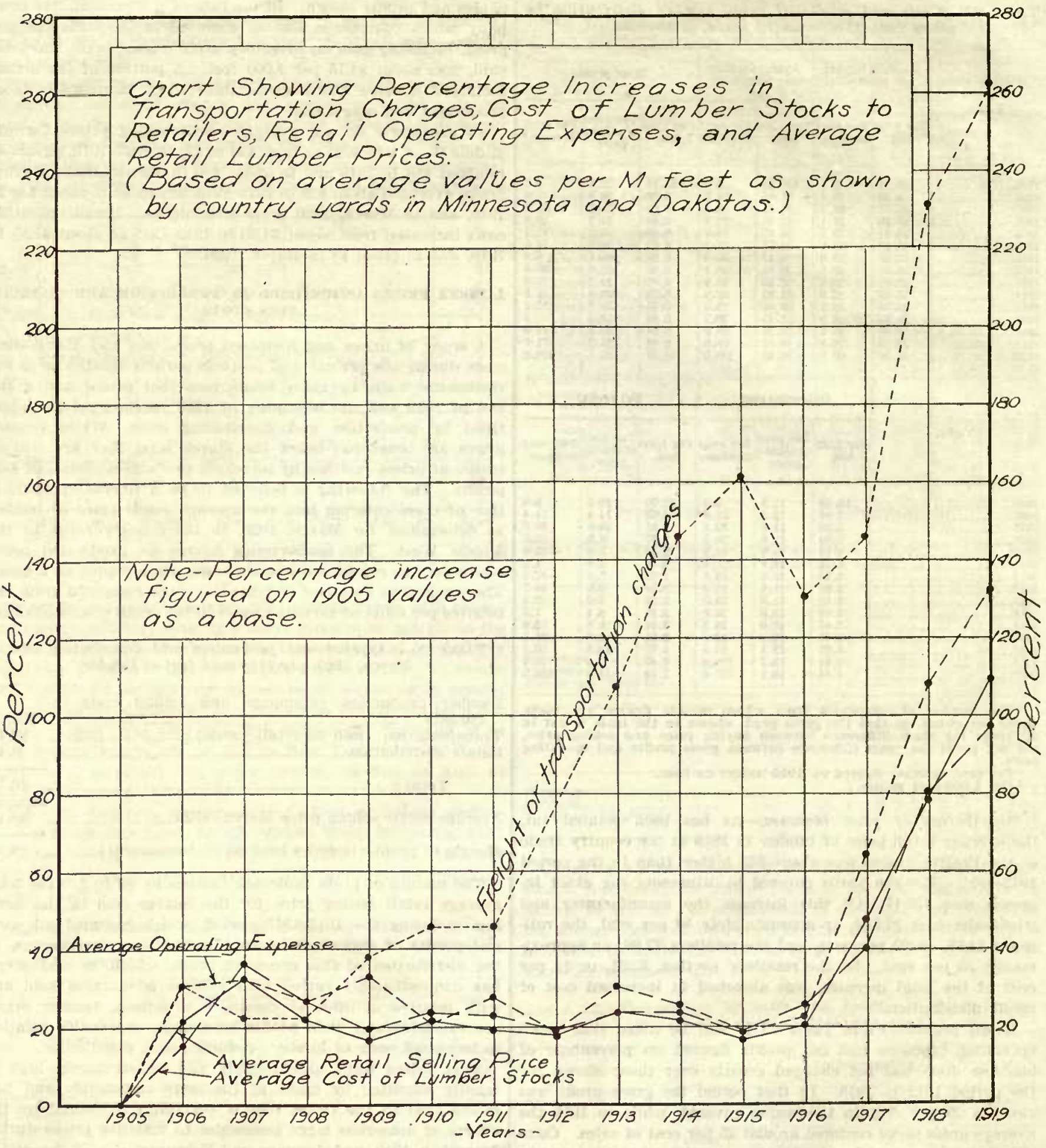

Fig. 20.

Several of the iargest companies operating both mills and retall yards, for example, sought to stabilize prices on their own responsibility, and their efforts unquestionably had a farreaching effect in breaklng the rising prices and bringing about a slight deciine, ranging from $\$ 1$ to $\$ 10$ per thousand, according to grade. Many iumbermen admit that prices went so high that demand was automaticaliy checked. There is ample evidence throughout the Midide West that lumber prices reached a point which aroused pubilc indignatlon in many communities, and that this feeling, combined with a widely advertised announcement of one of the largest prorlucing and distributing companies that it proposed to stabilize prices on the basis of its
January list, resulted in a sharp failing off in buying. An extract from the announcement issued by this company late in February reads as foilows:

The Interests comprising the group have come to recognlze that this condition of tbe lumber market is injurious to the public and to the industry generally; that the uncertainty even more than the price level is demoralizing and results in enhanced cost of building and discourages construction, and that unless something is done to check the present tendency toward further and frequent and Irregular advances which have no relation to costs of production the sltuation will become stili more deplorable.

The intent of tle company to stabliize prices was construed by the pubiic and the press as a cut in prices, and buyers quite 


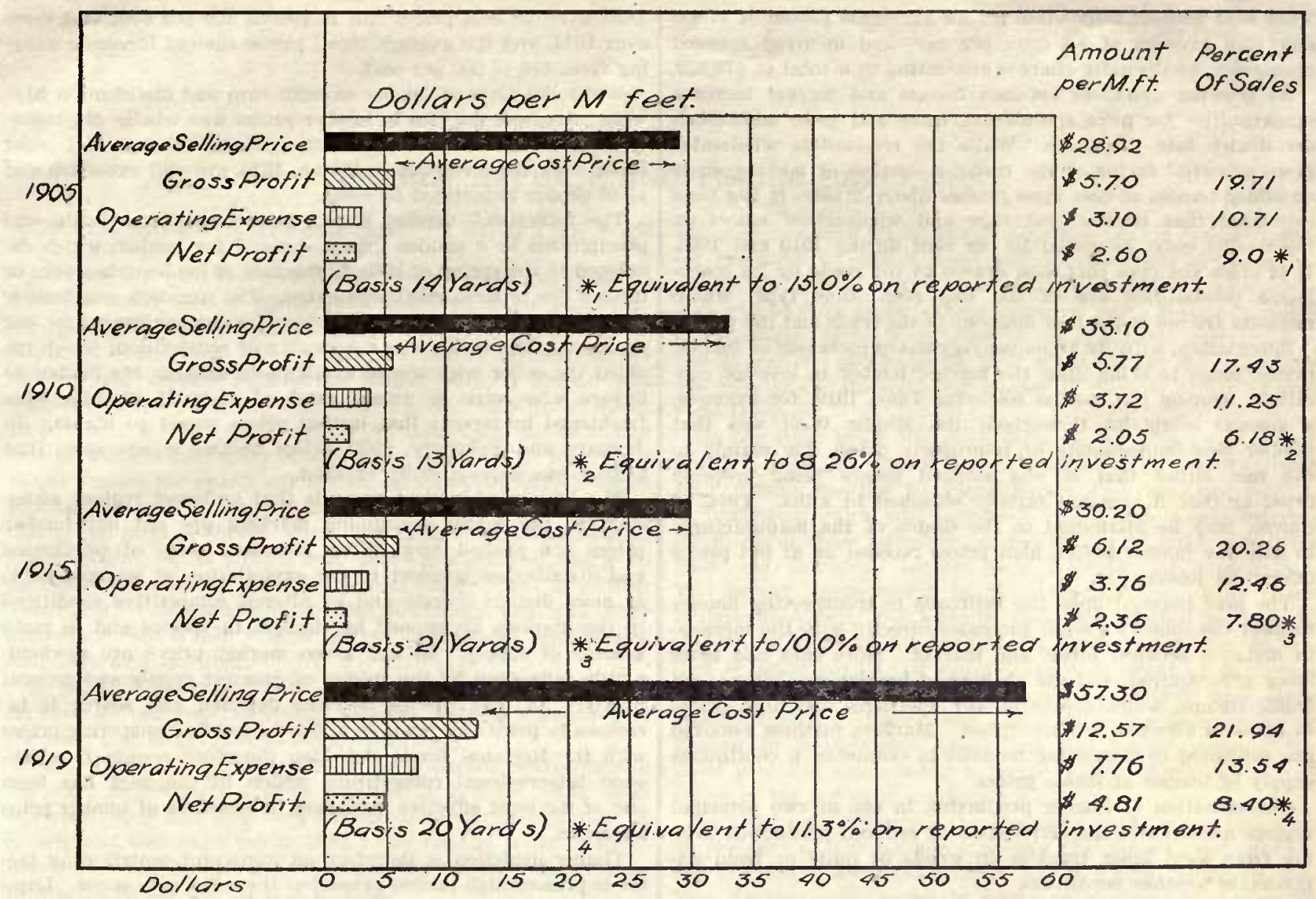

Fro. 21.-Comparative average selíng prices, all classes of lumber sold, gross profts, to tal operating expenses, and net profits for country retali lumber yards in Nebraska, for years 1905, 1910, 1915, and 1920.

generally throughout the northern portion of the Mildale West, in whlch the company operates retail yards, deferred purchases in older to buy on the company's list or to await similar reductions throughout the trade.

A statement issued about the same tlme by the president of another group of companies contained the following:

We regard the present prices of lath as detrimental to the best interests of all branches of the trade and not defensible elther on the basis of production and distribution cost or on the hasis of a fair market value.

\section{PRICE CONTROL.}

Neither time nor faclities were avallable to investlgate the extent, If any, to which prices since the armistice have been subject to artificial control. It is believed, however, that the duta presented are fairly conclusive in indicating that during the last half of 1919 and the first months of 1020 no control of prlces was necessary to lift prices.

\section{SOME SPECIFIC EFFECTS OF REGIONAL DEPLETION ON PRICES.}

Reglonal forest exhanstion, with constantly increasing distance between forest and market, gives rise to many accessory conditions vitally affecting the price of lumber to the consumer. Among the more important are:

Opportunities for speculation in lumber prices by both producer's and distributors tend to Increase as the distance between forest and market becomes greater and as a species of lumber becomes scarcer. Durlng the 8 or 10 months preceding March, 1020, much speculatlon entered the trade in markets far removed from the producing regions. The common use of the reconsignment privilege, for example, by whlch cars of lumber are shipped prior to sale, the shlpper or wholesaler, as the case may be, relying upon favorable sale whlle the lumber is in transit or when it reaches a consignment polnt, was a fruitful source of speculation. These cars were often held for bid prlces and served to intensify the auctlon market and to lift prices.

During the past year demurrage charges on translt cars amountlng to $\$ 100$ and $\$ 200$ per car were not uncommon. The records of transit cars at the Minnesota transfer alone show that during the period Oetober, 1910, to March, 1920, 3,000 cars

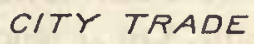

Average of 3 Companies

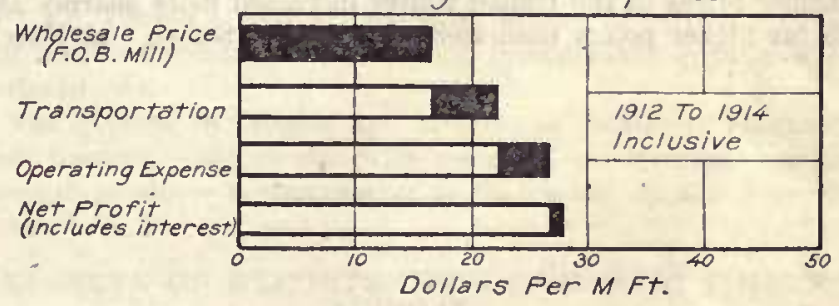

A Representative Firm

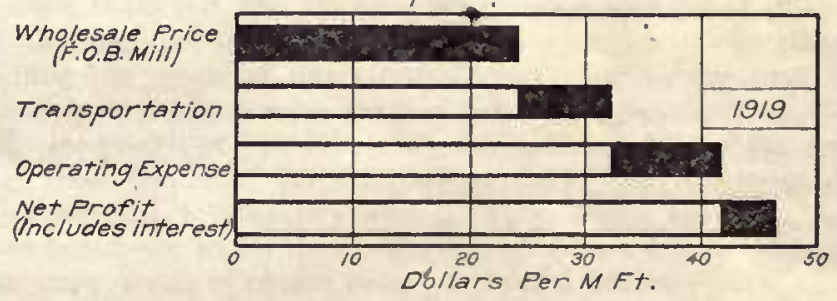

F10. 22.-Comparison of the essential cost factors in the retall price of lumber, Kansas City. 
were held without disposition for an aggregate period of 17,453 days-an average of 5.8 days per car-and incurred accrued demurrage and penalty charges amounting to a total of $\$ 76,529$.

As growing dlstances between forests and market Increase opportunitles for prlce speculation, more and more middlemen are drawn into the trade. While the responsible wholesaler is an essential factor of the trade, a surplus of mlddlemen is an added burden of cost upon lumber distrlbution. It has been estimated that lumber brokerage and wholesalers' offices on the Pacific coast Increased 50 per cent during 1919 and 1920 . It is often the case that men drawn to the trade by its speculative possiblities are of the less responsible type, whose methods are not to the best Interests of the trade and the public.

Speculatlon, with Its accompanylng sharp lncreases of lumber prlces, tends to brlng upon the narket lumber in inferior conditlon. During the months followlng June, 1919, for example, a general complaint throughout the Middle West was that lumber was inadequately or Improperly dried, due mainly to the fact either that it was slipped before being properly drled or that it was too rapidly seasoned in kilns. This, of course, may be attrlbuted to the deslre of the manufacturer to ship the lumber before high prices receded or at bld prices offered by jobbers.

The load imposed upon the railroads in transporting Jumber to meet the country's needs increases directly with the increase in distance between forest and market. More cars and more labor are required, and the chances of breakdown, delays, and traffic tie-ups, whlch create lumber shortages and high prices in markets affected, are multiplled. Markets farthest removed are subjected to Increasing hazards in obtaining a continuous supply of lumber at stable prices.

Concentration of lumber production in one or two principal regions accentuates the seriousness of reduced production arlsing from local labor troubles in woods or inllls or from unfavorable weather conditions.

The cutting out of timber in different regions carries with It a change in the character of luniber stocks in dependent regions both as to species and grades. This tends to confuse the trade and upset industrles dependent upon certain grades and species of lumber as a raw product. At the present time many large wood-using concerns which have developed their factorles and thelr products on the basls of special woods are facing with great concern shortages in the market supply of these woods, and in many Instances have had to turn to other species involvlng new problems of manufacture.

\section{SUMMARY OF PRINCIPAL PRICE CONCLUSIONS.}

During the lntter half of 1919 and the early montlis of 1920, lumber prices in the United States increased more sharply and to far hlgher points than were ever known before. In March,
1920, average mill prlces liad Incleased 300 per cent and more over 1914, and the average retall prices showed Increases rangIng from 150 to 200 per cent.

While the costs of lumber manufacture and distribution likewise increased, the rise in lumber prices was wholly disproportionate to these increases. Present prices, although somewhat lower than those reached in March, 1920, are still excessive and yleld protits unjustified by costs.

The "auction" market which characterized the trade was precipltated by a sudden urgent demand for lumber, which developed in the spring of 1919 , in the face of Inadequate stocks of lumber due to subnormal production. The situation was further aggravated by a restricted movement of lumber caused by car shortage. The result was a lessening of competition, which enabled the seller with stocks available to auction his lumber to buyers who were ln urgent need of material or who were frightened by reports that lumber prices would go blgher. In January and February, 1920, prices became so excessive that buying was automatically checked.

The history of lumber prlces is that as forest regions accessible to the larger consuming markets are cut out lumber prices are pushed upward by increased costs of production and distrlbution Incident to the exploitation of less accessible or more distant forests and by altered competitive conditlons in the markets occasioned by changes in species and in maln sources of supply. In any given market prices are predomlnautly influenced by the specles of greatest supply and general utility. As that species becomes depleted and scarce it lncreases in price and tends to draw the level of competing prices with it. Regional forest depletion therefore results in weakened interregional competitlon, which in the past has been one of the most effective influences in restraint of lumber price advances.

Timber depletion is therefore an important contributlng factor in present high lumber prlces but Is not the only cause. Lumber production bas fallen off to a marked degree in many regions as a result of the cutting out of the forest. Freight congestion, climatic conditlons, labor troubles, and other factor's which have reduced output in the reglons still malntaining large industrles have, as a result, been greatly emphasized and have been dlrectly related to depletion in their effect on prices. Transportatlon charges have been Increased to most of our largest consuming centers. Competition among manufacturers has been reduced and a greater opportunity created for manufacturers and dealers to auction their product at higher prices. All of these factors have tended to increase lumber prices and have accentuated depletion. If large-scale production had stlll been possible in New England, New York, Pennsylvania, and the Lake States, there can be little doubt concerning the beneficial effect upon market stability and lumber prices. 


\section{LUMBER EXPORTS AND TIMBER DEPLETION.}

\section{LUMBER EXPORTS BEFORE AND DURING THE WAR.}

I'rior to the war, the United States exported annualy about 3 billion board feet of lumber and saw $\operatorname{logs}$, aside from considerable quantitles of railioad ties, staves, and other wood prolucts. The expopt trade absorbed abont $8 \frac{1}{2}$ per eent of the lumber cut. Nearly half of the lunber shipped abroad was soutliern yellow pine, and softwoods ail told constluted about 79 per eent of the export trade. An important factor in the foreign trade is the export of hlgh-grade hardwoods. More than 10 per eent of the yearly ent of oak, or about 300 mlllion board feet (mostly whlte oak), was exported, In addition to 41 million feet in the form of stares. Seven per cent of the annual cut of vellow poplar, or 35 million feet, was exported, and nearly 50 ver cent of the yearly eut of black walnut, or about 25 million hoard-feet. Conslderable quantities of hickory, ash, and other high-grade woods for vehicle parts, agrleultural implements, etc., were also exported.

In 1913,37 per cent of the tumber exports were shipped to Europe, 30 per cent to North Amerlea (chiefly Canada and Mexico), and 16 per cent to South Ameriea.

The foreign lumber trade fell off to a marked degree cluring the war, partienlarly lumber exports to Furope. The total exports in 1918 and 1919 were but one-third of the quantities of hunher and logs exported in 1913. The forelgn trade in hardwools lits shown the least deeline, the volnme exported in 1918 behig 88 per cent of that in 1913.

\section{PROBABLE DEVELOPMENTS IN LUMBER EXPORTS.}

Fullowlug the suspension of hostilities, lumber exports have leen very stow in returning to their prewar volume, mainly oll account of exchange rates running agalust European comtries, higl eharter rates on shipping, and the unprecedented denand and high prices for lumber in our domestic markets. As more noruat tracle eonditlons with Europe are reestablished there will undoubtelly be a marked Increase in lumber exports. The emergency needs of Europe for reeonstruction and longdelayed expansion In houslng faellities, raitroads, etc., have been estimated at 7 billion feet of lumber annually for some time to come orer and above the consumption of normal thes. Great Britain, Franee, Italy, Germany, Belgium, and Holland are tumber-importing nations now experiencing exceptional and often acute shortages of wood as an aftermath of the war. For the most urgent reconstruetion and expansion, particulariy of rallrouls, these comntries wlll presumably seek to obtaln lumier in large quantities from the United States as soon as exchange rates reach a stable and more satisfactory basis. Inquiries for several million railroad ties from Great Brltain and France have, for example, been made of Ameriean manufaeturers, and indications point to a relatively steady rleuand from Europe for this product.

It is, nevertheless, improbahle that the United States will be cillod upon for any eonsiderable part of the ordinary grades of building lumber required in the reconstruetlon of western Burope. Euroje itself contains large quantities of timber suitabte for such purposes, partienlarly in Russia, Finland, Sweden, Nolvay, and the new eountries earved out of the AnstroHungarlan Emplre. Large lumber stocks aecumulated in the countrles of the Baltic Sea during the war awalt marketlng.
The pressure upon all Europenn countries having extensive forest resourees to explolt them and develop trade relations for marketing their products as a means of industrial rehabilitation will be very great. These countrles, with their advantage of proximity, better knowledge of trade eustoms and requirements, and the cherpness of theil produets, bid fair to supply the butk of the demanids for lumber of general utlllty arising from the war.

On the other hand, wuropenn demands for high-grade timber produets from the United States, such as large struetural and ship timbers, floorlng, hardwood staves, and furniture, vehlcle, or implement stoek wlll increase. Higl-grade wools suitable for many of these purposes can not be had in large quantlties from any luropean. sources now available for exploitation. The reeent Improvement in the exehange rate with Great Britain apparently has already brought a marked lnerease in the British demand for hardwools, which is a factor In further reducing stocks and maintaining high prices on hardwood lumber required by Amerlean turnlture makers and other manufacturers. Hiekory and ash handies are now going to Europe in considerable quantities, the foreign demand for these prolucts again being a factor which affeets stocks and [1]lces in the domestie markets.

As previnusly indicated, the Europman trade forms less than 40 per cent of our lumber exports. The development of Centrat and South America, parts of Afriea, China, Australia, and New Zealand will naturally result in a gradual increase In Inmber exports to those countries. Central and South America, while containing large hardwood forests, are now dependent upon Imports from the United States, Canada, and Sweden for the bulk of their softwoods, the ehlef staple in international timber trade. Several of these regions nay in time develop forest industries suffieient to supply their own needs, and new sourees of international lumber supply may be developed in regions llke Siberia. Nevertheless, the United States must anticipate a gradual but material increase 10 the demand for Its lumber products from these parts of the world for some time to come. This demand whll eomprise mainly lumber of relatively high grade. It will, however, probably run to less speclalized and high quality produets than the Furopen trade and witl consist elilefly of the better grades of softwood bulldlng and construction lumber, with considerable quantities of rallroad tles.

The exports to Canada and Mexico, on relatively short-rail and coastwise shipments, will comprise an average run of sawmitl produets corresponding to-that taken by the domestie trade.

\section{EFFECTS OF EXPORTS UPON DOMESTIC TIMBER SUPPLIES.}

The dlepletion of the virgin forests of the United States is making itself felt first through the growing scarelty of timber of high quality-the produets eut from large, elear logs representlng the cream of our virgin forests. During the past 25 years stel produets have risen in price more rapidly than the common grades of lunber. The most serlous effect of the forcign trade with be to increase the shortage of high quality products, because it is exactly suel products which are short the world over and which lnmber-importlng nations will in the long lun most deslre to obrain from the United States. 
This effect will be most pronounced in the case of American hardwoods. The foreign demand for such species not only Includes cablnet, furnlture making, and finishing woods of special beauty, ilke walnut or quartered oak, but also many woods used in manufacturing essentials of commerce and inlustry, llke oak and hickory wagon stock, hickory spokes, hlghgrade car stock, ash and hickory liandles, woods used in agricultural implements, and the like. The suppiy of old-growth hardwoods from whlch most of these products are obtained is nearing its end. Our domestic industries are securing such materials with increasing difficulty and cost. Except as substitute woods or other materials may be found, the growing shortage of these products must in any event seriously handicap Anerican industry and commerce.

The second important bearing of forelgn shipments is upon the remalning supply of high-grade southern yellow plne whlch, up to the present time, has furnished about half of the total lumber exports. The materials which the forelgn consumer deinands include a large proportion of high-grade flooring and other forms of finish and large timbers for shipbuilding and other structural purposes. The situation as to the supply of these products is less serious, and quite unlike that which holds true of the hardwoods. The total production of yellow-pine lumber wlll probably decline steadily during the next 10 or 15 years; and the production of high-quality products from old growth will drop off still more rapidly. Such hlgh-grade products will, however, continue to be cut from particular localities or holdings, though in dimlnlshed amounts, for 30 to 40 years, and the substitution of western softwoods for both export and domestic products now made of southern pine ls entirely pructicable.

In the third place, export demands will strike the large supplies of high quality softwood timber in the Western States. The Pacific coast carries on a gladually increasing trade with tile Orient, with Australia, with South America, and with Europe. It will logically repiace the exports of southern pine as that timber is further depleted. Here, again, the foreign demand will take mainly high-grade products, particularly large structural timbers, shipbuliding materials, and the better grades of clear flooring and other forms of finish. With this demand for high-grade materials will probably be supplied varying quantlties of railroad ties and generai utility lumber.

The large virgin forests of the West will sustaln the maximum demand made upon tilem by the export trade for many years without serious effect upon domestic markets. The domestic demand for high-quailty timber products from the West will, it is true, Increase with rapidity as their production in the South falis off. 'And in the West, as in the South, the first evidence of depletion wlli be a scarcity of products of high quaiity. There is this marked difference, however, in the West, that the existence of large National Forests where tlmber is cut under careful restrlctions affords a means for reserving reasonable quantlties of high-quaity timber and for producing stumpage of this grade.

It must therefore be recognized that a material increase in the export iumber trade would accentuate the shortage of hlghquallty products available to American consumers. The problem presented by lumber exports is not serious from the standpoint of quantity. It may prove serious from the standpoint of quallty. Scarcity of high-quality products essential to our siip and car building and many other. Industries 1 s the first and one of the most serious effects of timber depletion.

The eventual solution of the problem presented by an active foreign trade is therefore ldentical with the remedy for depletion through domestlc consumption, namely, not to restrict the use, but to increase the production of timber by getting ali forest-growing land at work. It must be recognized, however, that this remedy in itself will not entirely meet the need for timber of high quality. With some exceptions, such materlal can not be grown in less than 150 years; and even if every acre of denuded land in the United Státes were planted to-morrow, a long tine would elapse before the depletion of high-quality stumpage whlch has been cut so freely from our virgin forests could be made good. Furthermore, the private landowner can seldom afford to carry timber crops durlng the long periods necessary to produce material of high quality. The most effectlve means of overcoming the shortage of high-gracle timber is the creation of public forests which can be utilized to the extent necessary for the production of large tlmber or special products.

The bulk of the lligh-quality timber produced in France and otiler countries of Continental Europe Is grown in public forests, it belng a recognized function of the Government to produce on its forest lands the classes of material which will not be grown in sufficlent quantity on private lands because of the the and cost involved. This policy has alrendy been appiied to the hardwood forests acquired by the United States in the southern Appalachians pursuant to the Weeks Act. As far as practicable, these forests will be handled so as to produce highquality hardwoods rather than railroad ties and common lumber, so that they may be at least a factor in meeting the shortage of such products. But no adequate provision for the grow. ing of hlgh-grade eastern woods has yet bcen made. It can be uade only by largely extending the public forests in the Eastern States.

\section{IMPORTS OF FOREST PRODUCTS.}

During the four years preceding the war the lmports of lumber and logs ranged from $1,100,000,000$ to $1,300,000,000$ board feet, or ahont one-third the volume of exports during tine same period. Beginning with 1917 , there was a marked increase in wood imports. In 1918 imports exceeded exports by $100,000,000$ board feet, and in 1919 the excess of imports was probably inuch greater. Aside from the importation of $1,370,000$ cords of pulp wood from Canada in 1918, the Unlted States imported 596,000 tons of wood pulp and 516,000 tons of paper, chiefly from the same source.

Imports of timber and timber products fali into three classes: (1) Cabinet woods, llke mahogauy and clgar-box cedar, and other valuable woods, like South American greenheart, which can not be obtained in the United States. The imports of cedar amount to nearly $20,000,000$ board feet anmually, and time imports of malogany to $50,000,000$ board feet.

(2) Saw logs and manufactured lumber from Canada, silipped into the Unlted States by the natural routes of commerce on the Atlantic and Pacific coasts and by favorabie railroad channels. Such imports aggregate about 1,000,000,000 feet per year, aslde from which Canada also ships close to a bililon shingles Into the United States annually. These lmports compete dlrectly with sinilar products manufactured in the United States. There is, Indeed, approximately the same flow of lumber across the Canadian boundary in each directlon, determined by the favorable location of consuming regions in one country witi respect to lumber-producing centers in the other.

(3) Paper and materlals for making paper. The imports of pulp wood, pulp, and manufactured paper in 1018, practically all of which came from Canada, were approximately $2,071,000$ tolls. Imports of corresponding products were still greater in 1919. They furnish about two-thirds of the newsprint paper consumed in. the United States, a proportion which will grow steadlly unless the foreign trade policy adopted by Canada prevents.

Other imports of forest products are at the present time of negligible importance. Prior to the war the United States Imported considerable quantities of chemical pulp and high-grade papers from Scandinavia, a trade whose partial resumption is to be expected. A small quantity of lumber is shipped to our west coast from Japan and Korea. The enormous timber re- 
TIMBER DEPLETION, PRICES, EXPORTS, AND OWNERSHIP.

59

sources in Siberia have not yet been developed sufficiently to support a foreign lumber trade.

'The two important classes of products for which the United States now depends upon foreign countries are cabinet and other extremely valuable woods from tropical countries and paper or its law materials. Our dependence upon Canada forpaper is an extremely important factor which must be reckone with for many years to come. This results in part from the depletion of pulp-making woods in the eastern United States and ln part from transport and inanufacturing conditons which have prevented the paper-making industry from utilizing pulp timbers available in the Western States and Alaska. Adequate development of our western pulp-wood resources could make the United States independent of foreign supplies of paper.

EXPORT TRADE POLICY.

It must he recognized that, unlike most articles of commerce, the replacement of a considerable part of the raw material con- sumed ln lumber exports will, under the best conditions, be a slow and difficult process. Foreign trade in softwoods has less serious effects than the export of hardwood products; a foreign trade in such artleles as softwood railroad ties and common lumber is the dicast serious of all since such commodifies can be produced with comparative rapidity in large quantities once growth replaces devastation of our forest lands. On the other hand, foreIgn demands for higli-grade hardwoods endanger certain of our "key" Inclustries such as the manifacture of agricultural implements, vehicles, and handles Without any exports we face a serious shortage in their raw materials. These facts should be considered in determining the foreign-trade policy of the country and in weighing the advantages of reciprocity. Our fundamental national policy, however, should be for timber growth rather than the regulaton of timber use. If the export trade in lumber is to be regulated, such regulation should be discriminating and should apply to the grades and products in which a shortage is most imminent and most menacing to domestic industries. 


\section{CONCENTRATION IN TIMBER OWNERSHIP, MANUFACTURE, AND MARKETING.}

\section{CONCENTRATION OF TIMBER OWNERSHIP IN 1910.}

A thorough investlgation of timber ownership in the Lake States, the southern pine region, and the Paclfic Northwest was made by the Bureau of Corporations in 1910. At that time these three great forest regions contained about 80 per cent of all the standing timber in the Unlted States. The two most strlking facts reported by the Bureau of Corporations, following its investigation, were the concentration of control of standing timber in comparatively few large holdings and the vast scale upon which the speculative purchase and holding of timver In advance of its use had been conducted. Both of these conditions were attributed dlrectly to the public-land pollcy of the Unlted States. The Bureau of Corporations found that 48 per cent of the standing timber privately owned in these three regions, or 839.7 billion feet, was held or controlled by 195 owners. Three large corporatlons held between them 238 billion feet, or 11 per cent of all the privately owned timber in the United States. The concentratlon of standing timber in large loldings was mast fully developed in the Lake States and the Pacific Northwest.

The degree of concentration of standing timber in 1910 in the States covered by the investlgation of the Bureau of Corporations, and subsequent changes or tendencles in so far as it has been possibie to determine them, are summarized in the following brief account of timber ownership in a number of the more important forest reglons:

\section{TIMBER OWNERSHIP IN THE NORTHEAST.}

The 1910 investigation did not cover this region. The only tImber holdings of large size in New England are located lu its northern softwood forests and have been consolidated primarily to secure large supplies of pulp wood. Fifteen owners have acquired something over $5 \frac{1}{2}$ milion acres in Maine, New Hampshlre, and Vermont, or nearly one-fourth of the forest area of these three States. These 15 owners undoubtedly control at least half of the supply of pulp wood in New England. The process of timberland concentrution is still going on to a considerable degree, especially in Maine, where the large properties of one of the paper companles were acqulred and assembled during the past three years. In New Hampshire the United States itself has acquired a comparatively large timber holding through the purchase of over 400,000 acres in the White Mountains under the Weeks law.

The pulp-wood forests of New England are very largely beld on an operating rather than a speculatlve basls. The nonoperating owners in practically all cases are selling timber to opelating companies for current logging requirements, retaining the land.

In New York 17 pulp and paper companles have aggregate holdings of nearly 800,000 acres. The largest of these ownerships exceeds 200,000 acres, and the second in size exceeds 150,000 acres. Practically all of the softwood stumpage in New York is rery strongly held, and there is little tendency toward further concentration at the present time.

A significant fact in New York is that the State itself is the largest owner of merchantable timber, having acquired $1,886,000$ acres of forest land in the Adlrondack and Catskill Preserves, which contaln 60 per cent of the puip timber in the State. The cutting of these lands ls prohibited by the State constitution. The situation in New York is thus in striking contrast to that in Maine, where almost the entire supply of pulp timber is in private ownership.

\section{OWNERSHIP OF SOFTWOOD TIMBER IN THE SOUTH- ERN STATES.}

The Bureau of Corporations reported in 1910 that 14 holders controlled three-fifths of the cypress in Louisiana, and that 11 owners controlled one-half of the cypress in Florida. Each of these 25 owners had acquired more than 250 million feet of cypress stumpage. There has been comparatively llttle change in the ownership of cypress land since 1910. The limited supply and higl value of this timber and the large investments requiled for operating plants tend to keep the stumpage in the hands of relatively few owners. The enlargement of the existing cypress holdings is becoming more and more difficult, and the total quantities of timber held by the groups of large owners are diminishing as cutting progresses.

The Bureau of Corporations reported that 29 holders in 1910 owned 22 per cent of the yellow-pine timber ln the Southern States, eacl of these owners having acquired over 2 billion board feet. Sixty-seven owners leeld 31 per cent of the soutlern pine, but the ownership of 50 per cent was distributed among 307 holdings.

The concentration of southern pine in large holdings appears to linve practically stopped about 1909 . The number of holding companies which are not operating is very limlted, sales of tinuber are very few, and practically all of the remaining stumpage is definitely related to manufacturing plants.

The southern pine belt well lllustrates the increasing degree of concentration of tlmber of high quality as the depletion of forest resources continues. 'The South contains to-day approxi. mately 139 billion feet of virgin pine, controlled by 5,401 saw. mills. It is estimated that in 10 years the remaining stand of old-growtlı pine will be in the hands of .147 mills, and that in 20 years the 30 -odd billion feet of virgin pine timber left will be held by 45 mills. The number of mills alone does not indicate the degree of concentration, since a number of corporations control and operate several mills.

The sonthern pine region also lllustrates the replacement of large sawmills by small operations, as the greater part of the virgln stumpage ls cut out and the industry passes over to the cleaning un of odds and ends and tle manufacture of second growth. The number of small sawwills in the South is increasing more rapidly than the number of large plants, which are closing down. During 1919 from 800 to 1,000 small unills were established in this region, a movement, of course, greatly stimulated by the hlgh lumber prices.

\section{OWNERSHIP OF HARDWOOD TIMBER.}

In 1910 the Bureau of Corporations found that timber ownership was less concentrated in the hardwood forests of the South than in any other region investigated. The sane is true to-day. Hardwood forests lend themselves to concentration much less readily than conlferons timber. The number of spectes in the usual stand is great. Manufacture and marketing must he highly specialized, with diversifled products demanded by a wide range of manufacturing industrles and other usels. Costs of production run ligher than in the case of softwond forests. Ilence the individual hardwood holilings have averaged much smiller and the average hardwool mill cuts much less timber than in the case of softwoochs. 
The anmual cut of 11 of the largest hardwood operators in the sontien Appalacinaus is about 400 million feet. This represents $12 \frac{1}{2}$ per cent of the cut of the region. The remaining $87 t$ per cent of the output is manufactured by companies whlch produce less than 10 millon board feet yearly in every case. In the Mississippi or "Delta" region less than 30 companies reported a lumber cut of more than 10 million board feet anmmlly. In the whole hardwood region there are no holdings comparable to the large operatlng groups in the softwood forests of the West and South.

At least 10 infllion acres of hardwood forest in the Appalachian Mountains are owned by coal, ofl, gas, and other mlning corporations. One and one-half millon acres have been acyuired ly the Federal Government as National Forests under the act of March 1,1911 . The remaining hardwood areas in this region, and the same appears to be true of the "Delta" hardwood belt, are widely distributed and largely in the hands of operating companies.

\section{TIMBER OWNERSHIP IN THE LAKE STATES.}

'The Burean of Corpor'ations reported in $\mathbf{1 9 1 0}$ a marked degree of timber concentration in the Lake States, particularly in the most valuable species. Six owners thus heid 54 per cent of the whlte and Norway plne In Minnesota, but only 2 per cent of the hardwoods, then rated as of inferior value. Thirty-two holdings in Minnesota, each exceedlng 60 million board feet, agrregated $\tau \tau$ per cent of the valuable plnes and but 11 per cent of the hardwoods. Ten holders had acquired 24 per cent of all the timber in Wisconsin and 12 holders had acquired :S ver cent of the timber of Michigan.

Since 1910 a good many owners have disappeared from the rolls in the Lake States through the exhaustion of their holdings. The few nonoperating holders appear to be dlsposing of their lands, and a very lal'ge proportion of the timber in the region is now attached to going operators.

\section{TIMBER OWNERSHIP IN IDAHO.}

In 1910, 61 per cent of the privately owned timber in Idaho, or 32.3 billion board feet, was held by 10 owners. Each of these holdings comprised over half a billion feet. The three largest owners jolntly controlled 46.2 per cent of the private timber in the State.

The concentration of timber ownership in Idaho appears to have practically stopped about 1907 . Since that time the larger holdings have remained practically at a standstill, except for depletion from cutting and exchanges between companies to secure a better blocking of stumpage for operating purposes. The stoppage of further timber purchases about 1907 appears to have been due to a full realization of the cost of carrying stumpage for long perlods in advance of opportunity for its manufacture and to the general period of lean year's which the lumber industry experienced, particularly from 1913 to 1915. For the same reason a number of nonoperatirg companies have constructed sawmills and become manufacturers.

Timber concentration bad, however, gone very far in Idaho, particularly in the case of western white pine, the most valuable tinber tree of the Nortbwest. Of the 20 billion feet of white pine in this region, 5 billion feet is owned by the Federal Government, chiefly in National Forests, the State of Idaho owns 3 billion feet, and 12 billion feet are privately owned. A single group of affiliated companies controls one-half of the privately owned white pine, or 6 billion feet. With the exception of the Northern Pacific Railroad, one of the largest timber holding companies in this territory, thcre is no tendency to break up or decrease the size of the larger properties. The Northern Pacific is disposing of its timber as opportunity affords. The State of Idaho has announced a policy of disposing of Its timber lands. There is a marked tendency in Idaho, however, to put timber holdlngs upon an operating basis and to construct additional sawmills in sufficient number to liquldate most of these great propertles within 25 or 30 years.

\section{TIMBER OWNERSHIP IN WASHINGTON AND OREGON.}

In these States, the Bureau of Corporations found in 1910 the most striking examples of timber concentration. Three owners controlied 191.3 billion board feet of timber. There were 83 owners who had acquired over a billion board feet. Their aggregate holdings were 411.7 billion feet, or 59.4 per cent of the privately held stumpage In the two States.

Since 1910 the three largest holdlngs in this region have been decreased. By decision of the Federal courts the land grant of 2,425,000 acres to the Southern Pacific Railroad Co. in Oregon has reverted to the Government. The Weyerhaeuser Timber Co. lias sold approximately 250,000 acres, chiefly to operating companies, and has itself become a large timber manufacturer. The Northern Pacific Railroad Co. has sold 522,000 acres of timberland in Washington, a considerable part of which has gone to operating companies.

In the State of Washington Individual holdings in excess of 25,000 acres, or approximately 1 billlon feet of timber, had as a group acquired 155,100 acres of additional timberland between 1910 and 1919 through the consolidation of small holdings. On the other hand, this same group had during the same period decreased its holdings by 970,630 acres through logging, timber sales, fallures, etc. The net area of timberland controlled by this group of approximately 32 owners had decreased in the nine years 815,530 acres.

In Oregon the holdings of the same size had, as a group, dropped 959,930 acres between 1910 and 1919 and added $1,437,580$ acres, a net increase of 477,650 acres. The increases represent principally the consolidation of small properties. Nuch of the timbered area of Oregon is stlil undeveloped and inaccessible for lumber manufacture. Timber values in this region are still low. The greater number of large holdings in Oregon are in such localities. Several of them have changed hands during the past 10 years, some tracts two or three times, due to the inability of owners to carry taxes, interest, and protection costs any longer. The holdings previousiy carried more or less as a speculation have in many cases passed into stronger hands,

There are still many thousand timberland claimants and swall owners in these less accessible regions who are anxious to unload; and the low values at which they are willing to sell thelr land has permitted the blocking of small boldings into large properties at prices which have attracted strong investors. In a considerable number of cases, companies preparing for lumber manufacture have not only blocked up small properties but have also purchased extensively from the larger holders theniselves. A process of concentrating small properties and one of breaklng down the very large propertles are thus golng on at the same time. These two movements taken together presage a change in tImber ownership in Oregon from a speculative to an operating basis and a large Increase in its manufacture of lumber.

The indlvidual holdings under 25,000 acres, or of less than about one blllion feet of stumpage, aggregate 17,000 in Oregon and 7,000 In Washington. Many of these small holders have retained their timber not from choice but from their inability to sell in locations isolated from present manufacturing centers. The smaller number of such holdings in Washington indicates the much more rapld development of the lumber industry in that State. The enormous number of timber properties of small or unimportant size in the two States on the northern Pacific coast not only show that there is still a very wide distribution of timber ownership in that region notwithstanding the concen- 
tration which lias taken place; but also that the process of concentration for timber holding as distinet from lumber manufacture had been cliecked, as in Idalio.

\section{TIMBER OWNERSHIP IN CALIFORNIA.}

The timberlands of California illustrated, in 1910, the same tendencies tuward a partial concentration in enormous holdings evident in Oregon and Washington. Nearly 75 per cent of the privately owned timber in the State, or $\mathbf{1 7 8 . 2}$ billion feet, was in 39 holdings. The seven largest owners carried 100 billion feet of stumpage; and one owner, the Southern Pacific Raflroad, liad acquired 35 billion feet through its Federal land grant.

The commereial timber lands of California comprise two distinct belts, the redwood forests bordering the coast, and the sugar and yellow-pine belt covering the eastern and northern mountain ranges of the State. In the redwood region the principal nonoperating owners are now 17 in number, with holdings ranging from 200 million to 5 billion board feet of timber. Eleven of these holdings comprise 1 billion feet or more; and In the aggregate they comprise $29,056,000,000$ feet. The princlpal operators in the same region are 13 in number, with timber holdings ranging from 240 million to 3 billion feet. Six of these companies have holdings of 1 billion feet or more; and the aggregate ownership of the 13 is almost 20 billion feet. A large part of the redwood stunipage that can be operated most economically is now controlled by operating companies, who also largely control strategic operating sites from the standpoint of coustwise or other shipments. There is stlll a large percentage of redwood timber in the ownership of nonoperating companies, but the general tendency since 1910 appears to have been away from further concentration. The number and aggregate hold- ings of the group of companies controlling a bllion feet or n1ole, for example, has decreased.

The principal holding companies in the pine region of Callfornia are eight in number. Aside from the enormous property of the Southern Paclfic Railroad, these ownershlps range from 600 million to 3 billion board feet. In addition, there are 14 large operating companies, one of which controls 15 billion feet of stumpage, while the holdings of the rest range from 181 million to 2.8 billion board feet. All told, these operating companies own over 29 billion feet of stumpage. There have been several transfers of ownership since tlie investigation made by the Bnreau of Corporations in 1910 ; but no important ehange as to the general concentration of timberlands. The present tendency ln the California pine region is toward the operation of timber areas and the liquidation of the investments which they represent wherever the location of the property permits. In line with this tendency, in California as in Oregon, a rapid increase in the installation of sawmills and volume of lumber output is to be expected.

\section{CHANGES IN TIMBER OWNERSHIP FROM 1913 TO 1918.}

The accompanying table, No. 26, prepared by the Timber Section of the Bureau of Internal Revenue, shows the increases and decreases in timber ownership between 1913 and 1918 by 368 owners. These holdings are distributed by groups through 17 forest regions, representing practically all of the important timber areas in the United States. The figures do not include all of the large timber holdings in the regions represented, but do, through showing what has happened in the case of a sample group of large owners in each region, draw an excellent picture of the tendencies in timber ownership the country over.

TABLE 26.-Depletion of timber reserves and net changes in timber ounership of large timber ouners in the important forest regions of the United States.

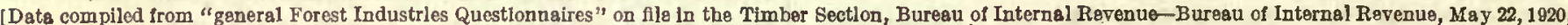
David Tason, Chief, Timber Section.

\begin{tabular}{|c|c|c|c|c|c|c|c|c|c|c|c|c|c|c|c|c|c|}
\hline \multirow[b]{2}{*}{ Forest ragions. } & \multicolumn{2}{|c|}{$\begin{array}{l}\text { Number of } \\
\text { owners. }\end{array}$} & \multirow{2}{*}{$\begin{array}{l}\text { Least } \\
\text { quan- } \\
\text { tity of } \\
\text { timber } \\
\text { owned } \\
\text { Mar. 1, } \\
1913 \text {, or } \\
\text { Dec. } \\
31,1918, \\
\text { (million } \\
\text { bd. ft.). }\end{array}$} & \multirow{2}{*}{$\begin{array}{c}\text { Aver- } \\
\text { age } \\
\text { stand } \\
\text { per } \\
\text { acro } \\
\text { Mar. 1, } \\
1913 \text {, } \\
\text { (thou- } \\
\text { sand } \\
\text { bd.ft.). } \\
\\
(\mathrm{M} \div \mathrm{I})\end{array}$} & \multicolumn{2}{|c|}{$\begin{array}{c}\text { Total area } \\
\text { owned } \\
\text { (thousands of } \\
\text { acres). }\end{array}$} & \multirow[b]{2}{*}{$\begin{array}{l}\text { Ratio. } \\
(\mathrm{O} \div \mathrm{F})\end{array}$} & \multicolumn{3}{|c|}{$\begin{array}{l}\text { Timbered area owned } \\
\text { (thousands of acres). }\end{array}$} & \multirow[b]{2}{*}{$\begin{array}{l}\text { Ratlo. } \\
(\mathbf{K} \div \mathbf{I})\end{array}$} & \multicolumn{3}{|c|}{$\begin{array}{l}\text { Timber owned (mil- } \\
\text { lions of board feet). }\end{array}$} & \multirow[b]{2}{*}{$\begin{array}{l}\text { Ratio. } \\
(\mathrm{O} \div \mathrm{M})\end{array}$} & \multirow{2}{*}{$\begin{array}{c}\text { Per } \\
\text { cent of } \\
\text { Mar. 1, } \\
1913 \text {, } \\
\text { timber } \\
\text { cut } \\
\text { during } \\
\text { period. } \\
\\
\\
100 \\
(\mathbf{N} \div \mathbf{M})\end{array}$} & \multirow{2}{*}{$\begin{array}{l}\text { Per cent by } \\
\text { which pur- } \\
\text { chases or } \\
\text { sales dur- } \\
\text { ing period } \\
\text { changed } \\
\text { quantity of } \\
\text { timber } \\
\text { owned } \\
\text { Mar. } 1, \\
1913 . \\
100 \\
(\mathrm{~N}+\mathrm{O}-\mathrm{M}) \\
\div \mathrm{M}\end{array}$} \\
\hline & Total. & $\begin{array}{c}\text { Not } \\
\text { opgr- } \\
\text { ating. }\end{array}$ & & & $\begin{array}{c}\text { Mar. 1, } \\
\text { 1913. }\end{array}$ & $\begin{array}{c}\text { Dec. } \\
31 \\
1018 .\end{array}$ & & $\begin{array}{c}\text { Mar. 1, } \\
\text { 1913. }\end{array}$ & $\begin{array}{c}\text { Cut } \\
\text { dur- } \\
\text { lng } \\
\text { perlod. }\end{array}$ & $\begin{array}{l}\text { Dec. } \\
31 \\
1918\end{array}$ & & $\begin{array}{c}\text { Mar. 1, } \\
\text { 1913. }\end{array}$ & $\begin{array}{c}\text { Cut } \\
\text { dur- } \\
\text { ing } \\
\text { period. }\end{array}$ & $\begin{array}{l}\text { Dec. } \\
31 \\
1918 .\end{array}$ & & & \\
\hline$A$ & B & $\mathrm{C}$ & D & $\mathbf{E}$ & $\mathbf{F}$ & $\mathbf{O}$ & $\mathbf{H}$ & $\mathbf{I}$ & J & $\mathbf{K}$ & $\mathbf{L}$ & $\mathbf{M}$ & $\mathbf{N}$ & $\mathbf{0}$ & $\mathbf{P}$ & $\mathbf{Q}$ & $\mathbf{R}$ \\
\hline $\begin{array}{l}\text { New England. } \\
\text { (M8., N. H. Vit.) }\end{array}$ & 40 & 2 & 60 & 3.8 & 5,675 & 6,519 & 1.15 & 5,386 & 797 & 5,365 & 1.00 & 20,522 & 3,255 & 19,885 & 0.97 & 16 & 13.0 \\
\hline 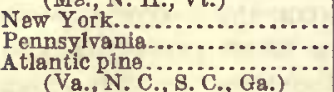 & $\begin{array}{r}11 \\
5 \\
11\end{array}$ & $\begin{array}{c}1 \\
\cdots \cdots \\
\cdots \cdots\end{array}$ & $\begin{array}{r}60 \\
60 \\
250\end{array}$ & $\begin{array}{r}5.6 \\
17.6 \\
4.3\end{array}$ & $\begin{array}{c}853 \\
550 \\
\cdots\end{array}$ & $\begin{array}{r}821 \\
545 \\
\cdots\end{array}$ & $\begin{array}{l}.96 \\
.99 \\
.9 .\end{array}$ & $\begin{array}{l}782 \\
166 \\
862\end{array}$ & $\begin{array}{r}136 \\
91 \\
415\end{array}$ & $\begin{array}{r}614 \\
83 \\
564\end{array}$ & $\begin{array}{l}.78 \\
.50 \\
.65\end{array}$ & $\begin{array}{l}4,400 \\
2,927 \\
3,664\end{array}$ & $\begin{array}{r}755 \\
1,936 \\
1,433\end{array}$ & $\begin{array}{l}3,620 \\
1,109 \\
2,375\end{array}$ & $\begin{array}{l}.82 \\
.38 \\
.65\end{array}$ & $\begin{array}{l}17 \\
66 \\
39\end{array}$ & $\begin{array}{r}-.5 \\
4.0 \\
4.0\end{array}$ \\
\hline Florida pina.................. & 7 & & 250 & 3.9 & & & & 100 & 361 & 592 & .79 & 2,878 & 1,305 & 2,112 & .73 & 45 & 19.0 \\
\hline $\begin{array}{l}\text { Gulf pine. } \\
\text { (Ala.; Miss., La., Tex., } \\
\text { Ark.) }\end{array}$ & 65 & 2 & 250 & 81 & & & & 4,890 & 1,828 & 3,854 & .79 & 39,419 & 14,733 & 28,423 & .72 & 37 & 9.0 \\
\hline 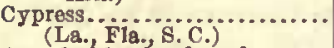 & 17 & 1 & 60 & 7.5 & & & & & & & & 3,322 & 1,752 & 2,625 & .79 & 53 & 32.0 \\
\hline $\begin{array}{l}\text { Appalachlan hardwoods. } \\
\text { (Va., W.... } \\
\text { Tann.) }\end{array}$ & 22 & 2 & 60 & 8.0 & & & & 657 & 256 & 601 & .91 & 5,284 & 2,271 & 4,275 & .81 & 43 & 24.0 \\
\hline $\begin{array}{l}\text { Appalachian softwoods........ } \\
\text { (Va., W. Va., N.C., Tenn.) }\end{array}$ & 8 & $\ldots \ldots$ & 60 & 10.4 & & & & 354 & 117 & 235 & .66 & 3,681 & 1,441 & 2,418 & .66 & 39 & 5.0 \\
\hline $\begin{array}{l}\text { Delta bardwoods ....., Mo............ } \\
\text { (Miss., Ark., La., }\end{array}$ & 20 & ... & 60 & 5. 6 & 577 & 737 & 1.28 & 524 & 163 & 545 & 1.04 & 2,948 & 894 & 2,891 & .98 & 30 & 28.0 \\
\hline $\begin{array}{l}\text { Lake States, Wi... Mich.) } \\
\text { (Minn., }\end{array}$ & 69. & 7 & 100 & 7.2 & 3,724 & 3,675 & .99 & 2,496 & 1,094 & 1,634 & .65 & 18,082 & 7,137 & 11,868 & .68 & 39 & b. 0 \\
\hline (ii......................... & 10 & 2 & 250 & 17.5 & 1,020 & 1,052 & 1.03 & 918 & 94 & 902 & .98 & 16,082 & 1,595 & & .95 & 10 & 5.0 \\
\hline $\begin{array}{l}\text { Washington (fir and pins)...... } \\
\text { Oregon fir }\end{array}$ & 40 & 6 & 250 & $\$ 4.0$ & 2,490 & 2,463 & .99 & 2,245 & 163 & 2,096 & .93 & 98,793 & 7,495 & & .88 & 8 & -5.0 \\
\hline (2..., & $\begin{array}{r}17 \\
8\end{array}$ & $\begin{array}{l}7 \\
5\end{array}$ & $\begin{array}{l}250 \\
250\end{array}$ & $\begin{array}{l}50.0 \\
16.0\end{array}$ & $\begin{array}{l}567 \\
674\end{array}$ & $\begin{array}{l}550 \\
720\end{array}$ & 1.97 & $\begin{array}{l}503 \\
616\end{array}$ & 29 & $\begin{array}{l}462 \\
633\end{array}$ & $\begin{array}{r}.92 \\
1.03\end{array}$ & $\begin{aligned} 25, \\
8,\end{aligned}$ & $\begin{array}{r}1,760 \\
322\end{array}$ & $\begin{array}{r}21,726 \\
9,548\end{array}$ & .86 & $\begin{array}{l}7 \\
3\end{array}$ & $\begin{array}{r}-7.0 \\
3.0\end{array}$ \\
\hline dwood. & 11 & 2 & 50 & & & 40 & 1.01 & & 31 & & .90 & & & & .89 & 12 & 1.0 \\
\hline California pine..... & 15 & 5 & 500 & 25.1 & 1,518 & 1,505 & .99 & 1,273 & 136 & 1,130 & .89 & 31,972 & 2,760 & 28,505 & .89 & 9 & -2.0 \\
\hline Total.................... & 376 & 42 & .. & 13.7 & 18,047 & 18,988 & 1.05 & 22,606 & 5,742 & 19,560 & .86 & 310,469 & 53,357 & 262,482 & .85 & 17 & 2.0 \\
\hline
\end{tabular}


The following notes on thls table have been furnlshed by the Timber Section of the Burean of Internal Revenue:

"In New England the 16 per" cent cut indicated In column $\mathbf{Q}$ is believed to be too low to be fairly representative for all of the owners in the region, for during thls period many of the larger operitors, desiring to guard heavy investments in pulp and paper manufacturing plants, secured their supplies of raw material as far as possible from timberlands other than their own. At the same time these owners gladly bought additional timber to the extent of 13 per cent of their origlnal holdings.

"In the case of New York the statement just made for New Engtand applies to column $Q$. In the case of column $R$, however, the owners did not increase their holdings through purchase, but in fact diminlshed them by one-half of 1 per cent through sales, owing to the fact that timberland at the beginning of the perlod was for the most part already closely held in New York and very little was changlng hands.

"In Pennsylvania there are very few Important timber holdings left. These are being rapidly exhausted, as Indicated by the fact that 66 per cent of the timber on hand March 1, 1913, was cut during the period, and by the further fact that the owners were able to secure only 4 per cent more during the period. In a reglon such as thls, where cuttlng has materially reduced the supply of virgin tlmber, the tendency is for an operator to replenish his timber reserve, so far as he is able, by the purehase of other available timber. For the same reason this tendency also obtains In the Atlantic plne, Florlda, Gulf pine, cypress, Appalachian hardwoods, Appalachian softwoods, and Lake States regions.

"The Atlantic pine region shows about the same situation as does I'ennsylvania, excepting that the exIstling supply suitable for large sawmill operations is not belng exhausted as fast.

"In the case of Florida, while the rate of cuttlng was hlgh, there were still considerable tracts of timber to be obtained for good-sized operations, as indicated by the 19 per cent excess of purchases over sales. In the Gulf coast pine region the rate of reduction of timber reserves was slightly slower than in the Atlantlc pine region; the opportunity to secure additional timber was better but not so good as in Florlda.

"We now leave the regions of the United States In which the timber supplles have been rather heavlly depleted and where operators are inclined to acquire as extensively as practicable additional supplies in order to prevent thelr reserves from falling too rapidly. We reach the western Unlted States, where there are still enormous supplies of virgin tlmber. Here during the perlod covered by the table there was little inclination to buy additional timber because of the exceedingly heavy load of timber already carried; In fact, many owners endeavored to liquidate thelr timber as rapidly as possible both by cuttlng and by selling. Those large owners who bought tlmber usually acquired only that offered at bargain rates. In Idaho, for instance, 10 per cent of the timber on hand at the beginning of the period was cut and 5 per cent acquired; much more than 5 per cent could easily have been acquired, for the avallable supplies ale large, If the owners included in the group had been In a buying mood. In Washlngton 8 per cent was cut, and an addithonal 5 per cent was sold. Sirnllarly In Oregon fir, 7 per cent was cut and an additional 7 per cent was sold. In the case of Oregon pine, California redwood, and Californla plne the condltions were not far different from those just mentioned."

Particular attention should be given to the ratio columns for "Timbered area owned" and "Timber owned." In the case of but one group-that of Oregron pine owners-does the total quantity of timber owned in 1918 equal that owned In 1913. In evely other legion the total group ownership dropped off durIng these years. The ratio is close to 100 in most of the reglons still havlng large areas of virgin forest, reflecting, first, contInued opportunity to acquire timber, and, second, the effort on the part of the larger owners to malntaln a constant but not greatly increased supply of stumpage for thelr mills.

It is also notable that the quantity of stumpage held in 1918 by the New England group is very close to that held in 1913. In several other regions low ratlos, such as 38 per cent in Pennsylvania, 65 per cent In the Middle Atlantic States, and 66 per cent each in the softwood areas of the southern Appalachlan and in the Lake States, are evidences of timber depletlon.

These data, compiled from the tax returns made to the Bureau of Internal Rerenue, confirm the general tendency, ascertalned by the Forest Service from study in the field, toward a decrease In the larger timber holdlngs in many reglons and putting timber ownership more largely upon an operating basis. These facts, however, do not necessarily Indleate a decrease in the proportionate amount of timber controlled by large owners.

\section{A SUMMARY OF THE PRESENT SITUATION AS TO TIMBER OWNERSHIP.}

In brlef, the situation as to tlmber ownershlp has not changed materlally from that reported by the Bureau of Corporations in 1910. Half of the privately owned tlmber in the United States Is In the ownershlp or control of about 250 large companles. About one-fifth of the total is owned by the Government. Several of the Western States also rank as large holders. The ownershlp of the remaining timber Is very widely distributed. There are 24,000 holdings of less than a bllllon feet in Oregon and Washington alone. The great bulk of the hardwood timber is distributed among many owners. It is roughly estimated that the farm wood lots In the States east of the Great Plains, aggregating $152,000,000$ acres, contaln two-fifths of the tlmber in this portion of the country, or approxlmately 340 billlon feet.

In nearly every forested region the group totals of the princlpal owners have either practically remalned stationary or decreased. The tendency on the part of these groups to acquire and malntain a relatively constant supply of standing timber as cutting progresses is marked in regions where the remalning resources permit. The decrease in the holdings of such groups In several of the eastern forest reglons is a clear indication of timber depletion. In many Indlvidual cases, of course, a further concentration of timberlands is in progress. This is particularly marked in the softwood forests of the Northeast, spurred by the scarcity and high value of pulp woods.

A realization of the carrying charge on long-term tlmber Investments, which may double the capital cost of stumpage every seven or eight years, has largely halted the movement for building up enormous speculative timber propertles which was In full swing prior to 1910. The tendency of the present, with some exceptlons, is to put the timber holding on an operating basis, adjusting its size to a practlcable scheme for underwritlng the cost of particular sawmills and logging improvements rather than carry large surpluses beyond operating requirements now clearly defined. A number of companles, hitherto timber investors rather than lumber makers, are becoming operators through the necessity of obtalning a current revenue to meet carrylng charges, and also because of the opportunities for profit afforded by the exlsting lumber markets. As a broad rule, therefore, partlcularly in the Northwest, timber lands are passing over from long-time speculations to blocks of raw material connected with partlcular manufacturing plants. As a phase of this process, the largest holdings are being reduced rather than increased.

On the other hand, this regrouping of timberlands is bringing new interests Into the Western States, chlefly as operators. While often buying timberland from the larger owners there before them or taking over going sawmllis, these new interests are also consolidating small holdings in order to block up deslrable operating units. They thus become large or comparatively large timber owners themselves; and their establishment in the West tends to even off decreases In the holdings of the 
rery large interests. By and large, the degree of concentration. indicated in the tindings of the Bureau of Corporations in 1910 has not been appreciably changed; but no general tendency is evident to extend control by increasing the larger holdings or by withholding timber from the saw. Indeed, the opposite is true in many regions.

Two factors inake the effect of timber concentration greater than it appear's. The first is the ownership of key ureas, strategically located at the outlets of valleys or other points, where they control to a considerable degree the operation of the back-lying or adjoining timberland. There are many cases where topography thus gives the owner of a key tract practical control over an adjolnlng quantity of tinuber which he may confidently expect to purchase more or less at his own terms when he is ready to log, but which meantime must be carried by others. Under the operation of the timber and stone act and othel land laws, many such tracts have been acquired withln or adjoining National Forests which in effect control considerable quantities of publicly owned timber, and the same situation frequently exists as regards private lands.

A second aid to timber control is the fact that the holdings of many, though not all, of the large owners comprise the most accessible timber in their regions, the timber wost cheaply lagged, and the timber of the best quality. A considerable part of the western stumpage is so inaccessible and costly to $\log$ that it will not be a competitive factor in the lumber market for many years. This is true, particularly, of much timber in the National Forests. Control of the more accessible and highgrade timber will strengthen the position of many large interests aside from the actual volume of stumpage which they own.

\section{CONCENTRATION TENDENCIES IN LUMBER MANU- FACTURE AND MARKETING.}

The most signiticant tendencles durlng the past five or six years bearlng upon the general question of timber concentration, however, are not in the ownershlp of stumpage, but concern a more highly organized control of sawmills and lumber marketing by groups of operations. Durlng the same perlod the industry has become more closely knit through the development of regional associations and other cooperative measures. The census of 1910 reported some 45,000 operating sawnills. The study made by the Forest Service in 1914 indlcated that the lumber industry at that tlme was very individualistic in character. An enormous number of mills, large and small, operated independently, and the vast majority of lumber-making establishments manufactured and marketed their products as competing unlts. The sawmill capacity of the country was much greater than tlie rolume of lumber which could be marketed. The bonded indebtedness of the industry was large and, In general, its financial structure was weak. The pressure of carrying charges on timberlands and indebtedness and on investments In manufacturing capacity too large for the market led to frequent periods of overproduction and of financial distress to many operators.

The change from these conditions which now appears to be in progress may be compared to the changes in the Iron and steel. lndustry during the period when the small foundries and steel plants were disappearing or being consolldated in a comparatlvely few large groups; or to the changes in the transportation industry during the period following 1870, when many small railroads were absorbed Into large trunk systems. These tendencies in the lumber industry may be summarized as follows:

\section{THE CREATION OF LARGE OPERATING GROUPS OF AFFILIATED} SAWMILLS.

The necessity of manufacturlng lumber in the vicinity of standing timber prevents the geographical concentration of plants to any degree comparable with most'other manufactures. Nevertheless, there is a distinct tendency, particularly In the
Western States, toward concentration of production through the central control of a considerable group of mills. Such control nuy be exercised through varylng degrees of stock ownerslslp, bonding or other financial relations, or affiliations of one forn or another. These operating groups range from 2 or 3 sawmills to 12 or more, with a combined cut of from two to three hundred million board feet yearly up to a billion feet. In several instances the group includes mills in two or inore of the principal softwood reglons-the Sonth, the Lake States, and the Northwest, and in some cases also embraces mills or timber properties in British Columbia or Mexico.

The wovement of southern lumber interests into the Western States is one of the significant phases of this tendency in lumber manufacture. Several of the large southern operators have recently acquired mills or timber properties in the West. In some cases this represcnts an expansion of existing lumberproducing organizatlons; in others, the mlgration into new territory of operathing units which have exhausted their tormer timber hollings.

With the development of such operating organizatious there is a certain elimination of sawmills and tlmber holdings which litherto have been unafiliated. The tendency of the large operatlng groups is to consolidate the boldings, large and smoall, in their vlcinity and thus acquire sufficient stumpage to supply their manufacturing plants for at least 20 or 25 years. The relation of the small mlll to this general movement is a complex one and, as will be indicated later, works in different ways in dlffercnt reglons. But as regards the principal remaining timber resonrces of the United States in the West the present tendency is unquestlonably "torvard a closer concentration of lumber manufacture in large units than has existed hitherto.

This development toward more large and powerful operating groups is but partial. The number of sawmills operating as independent units is still very large and still manufactures the greater part of the total lumber cut. Furthermore, as far as present indications go, the entrance of new organizations of large size into the lumber industry of the West has not tended to restrict competition. The newcomers, usually well organized, efficient, and well financed, have indeed in several instances introduced a new competitive element in the regions where tley located. This tendency in the lumber industry undoubtedly would make a process of "getting together" between the larger interests easier than it has been before, but it at least is not yet evldent.

\section{GREATER FINANCIAL STRENGTH OF THE LUMBER INDUSTRY.}

The study of the lumber industry In 1914 indicated that Its tinancial structure was weak. Incomplete records of bonds and other forms of indebtedness on tlmber lands and operations in the southern plne region and the West aggregated $\$ 151,000,000$. Stockholders' loans, current bank loans, and other forms of borrowing apparently had been carried often beyond the point of safety. Interest and maturities on the varlous forms of indebtedness formed a heavy charge upon the average thousand feet of lumber manufactured, and notably forced many sawmills to continue cutting during perlods when operation represented an actual loss and increased the overproduction which occasioned periodle demoralization of the industry. In the three years following 1912 there was a weeding out of weaker operators as a result of these conditions, and certain of the large timber holdings in the Northwest were broken up and passed into other control owing to the attempt to carry bonds and other forms of indebtedness beyond the capaclty of the business.

Within the last four years the financial strength of the lumber industry had radically improved. A large volume of timber bonds has been retlred. The flow of eastern capital, particularly from the Southern States, into western timber leglons has eliminated a certain number of wealkly financed tlmber 
owners and sawmill operators and has strenglhened the financlal backing of other concerns where no change in ownership was made. Higher profits in the manufacture of lumber during the past few years have elabled the lndustry, by and large, to wlpe out much old indebtedness and greatly improve its financial situatlon.

This change is clted because it is part of the general reconstructlon of the lumber buslness which is taking place, thus making It a better organlzed industry, and which tends to elimlwate certaln conditions which formerly made this industry one of the most highly competitive in the country. Tlie indebtedness of timber owner's and lumber producers was formerly a large factor in keeping up productlon with llttle reference to demand, and in causing the scramble to market the lumber cut at almost any price. To a considerable extent the lumber lndustry now appears to be passing out of a condition where excessive competition was forced upon a large portlon of its members by purely financlal exigencies.

The fact remains that the nature of timber properties tends to compel the operator to manufacture lumber steadily at the full capaelty of his plant and to dispose of hls product currently as it is sawn. This results from the cost of carrying large supplies of raw material. The "stumpage load" has forced many timber owners in the West to become operators, and the very necessity of llquldating timberland investments compels contlnuous operatlons.

The carrying charges on timberland thus tend to keep the lumber industry competitlve. In 1914 they compelled many mills to operate at a loss-for operation was still less costly than Idleness. The greater financial strength of the lumber lndustry will minimize the effect of thls baslc factor to some extent, but can not eliminate it. Once let lumber stocks equal or exceed the demand and it would again become a powerful competitlve Influence. Another safeguard against possible monopolistic tendencies in lumber manufacture is the publlc ownership of a third of the timber in the Western States, in the National Forests. The sale of public stumpage under the restrictlons enforced will foster independent mills not affiliated with the large interests.

\section{CONCENTRATION OF LUMBER MARKETING.}

I'robably the most significant pluse ln the reorganizatlon of the lumber industry is the development of large marketing units which landle the output of a considerable number of plants, under central control. This has gone considerably beyond the concentration of production through the control of groups of mills. A lumber sales company in the Northwest markets approximately a billion board feet yearly, cut by 11 alliliated sawmills. An agency in New York sells the product of 11 southern mllls, amounting to some 200 million board feet annually. The second of these exanples is much more typical llyan the first. There are many other groups of mills whose cut is niarketed jointly under management which may be identlcal with the ownership or affiliation of the mills thenselves or which may, in the form of a selling agency, be largely or wholly unconnected with the producing plants. One of the most common is the type of selling agency whlch markets the cut of 12 or 15 snall mills on a commission basls, givlng the mills a more efficient selling department than they Indivldually could afford.

The "line-yard" system of retaillng lumber, although followed for a good many years, is an lndication of the sane movement toward a closer organlzation of lumber marketing. In nuany cases large sawmills or groups of sawmills under the same financlal control maintain their own lines of retail lumber yards or are financially affilated witl companies operating llne-yard systems. The large wholesaler who contracts for the entire cut of a number of mills, or the entire cut of certaln grades of lumber, Is another factor. Many small mllls, partlcularly in the Southern States, while seemlngly lndependent operating units, are in fact grouped into relatively large marketing units through a single wholesaler who handles thelr product; and in many cases these small mllls are partly or largely financed by the wholesaler who markets thelr cut.

The movement in this direction, whlle only partially connected whth the ownership of tlmberlands, is undoubtedly the most pronounced feature of concentration in the lumber industry from the standpoint of tendencles in lts development and their bearing upon the interests of consumers. Concentrating the marketlng of lumber Into large unlts ls still far from complete. The 40,000-odd sawmills scattered all over the Unlted States do not lend themselves readily to such a process. Furthermore, the number of distinct marketing units, even those of large size, is still very considerable, and the proportlon of the lumber cut of the country handled by the largest of them is relatively small in comparison with other Industries. The largest unit of this character, for example, markets about 3 per cent of the lumber cut of the country. In partlcular reglons the proportionate control of lumber distribution by a partlcular organization may be much greater, and the policy of the organization as to local sales of the products handled by it of colresponding importance to the interests of the consumers.

In the general lumber trade the large selling organlzation has often been a strong competitive factor. Reachlng out for more business, it has not infrequently brought effectlve competitlon into regions where formerly it was lacking and glven better service to consumers in such ways as stabillzation of lumber grades, offerlng new grades or dlmenslons especially adapted to local requirements, or furnishlng plans for the construction of dwellings and farm improvements. In Itself this form of organization may be beneficial rather than harmful to the public interests, particularly in an industry llke lumber manufacture, which has been backward in the development and adaptation of its products to the requlrements of consumers. The danger lies in the possibllity of using large marketlng units as a medium for price control.

\section{DEVELOPMENT OF TRADE ASSOCIATIONS.}

Regional associations of lumber manufacturers have been in existence for many years. They have discharged certaln fuuctions of value both to producers and consumers of lumber, particularly in the standardization of lumber grades enforced by association inspector's and in correctlng evlls common in the industry to which its product is partlcularly susceptible through various practices of misgrading. The assoclations have also largely haudled the traffic interests of their members and have been the media througl which various forms of statistical and other information are assembled and distributed to the lumber producers comprising them.

The general reorganization of the lumber industry has involved inevitably an expansion in the actlvities of such assoclations and has given them greater Influence upon both the production and marketing of lumber. They have glven emphasis, for example, to the formulation and adoption of uniform accounting systems, tending to unlfy the accounting practices of lumber manufacturers, which in former days were extremely diverse and often haphazard and inaccurate. They have been the foremost promoters of the movement for guarantecing the quality of lumber products. Another activlty, developed particularly during the last six or cight years, is the assembling and distribution among menbers of the association or of a subsidiary organlzation of current reports on the mices received in lumber sales. The purpose of this work is to give the members of the association a common and up-todate understanding of the market which they are supplying. 
Ignorance of current market values, particularly on the part of small operators, has been one of the reasons for the very unstable conditions often prevailing in the lumber industry. It was evidenced and is stili to some extent evldenced by the wide range in prices at whlch the same grade of lumber is sold in the same locality.

Wilh lumber nanufacture and marketing so widely dlstributed, the industry has lacked a central medium for reporting price changes from day to day, like the wheat or cotton exchanges. No general and authoritative price data have been available to it, like those assembled and published by the Department of Agriculture on many agricultural products. The function of the regional lumbermen's association in assembling and distributing the prices reported on current sales has grown out of a real need on the part of many operators for better information about their market. It is a development common, in one form or another, to most of the large businesses of the country.

Solely as a matter of information, the current distribution of prices received by different members of the association tends to unify the rates at which lumber is offered for sale and to make increases or decreases in accordance with the fluctuation in the market more nearly similar at all producing plants. The same informatlon would doubtless be of equal valne to buyers of lumber, particularly to the smaller buyers less able to keep posted upon market fluctuations, if avallable to them. The price reports of lumber associations appear to have been made avaliable to lumber buyers in some cases, in other cases not.

The assembling and distribution of such information obviously forms a possible vehicle or medium for reaching more or less definite agreements or understandings controlling the prices at which lumber is offered. The extent to which it may serve as such a medium depends upon the policy followed by the particular association as to the degree of publiclty given to data of this character, upon the efforts which the association may make to induce its members to price their product in conformity with the highest rates shown by current reports, and upon the extent to whlch the individual lumber producers or selling organizations may use the data as a basis for pricecontrol agreements or informal understanclings. Properly employed, particularly with a large degree of publicity, such information should scrve to stabllize the lumber market to the advantage of botli producer and consumer.

\section{EFFECTS OF TIMBER DEPLETION UPON CONCENTRATION.}

It should be pointed out that the public effects of the concentration of a large part of the virgin forests of the United States in the lamils of relatively few large interests will become greater as forest depletion continues. It is to the interest of large operators wbo have unad: extensive investments in opcrating plants and in marketing organizations and who have built up widespread trade connections to maintain a continuous supply of stumpage for their mills. Carrying charges have placed more or less definite llmits npon the quantities of reserved timber which call be carried economically. As these quantities are reduced by cutting, however, it is to be expected, and the data on liand indicate, that the large operators will replenish them by purchasing available small holdings. $\Delta \mathrm{s}$ a general rule, the small mills are tending to be eliminated in the western reglons, where the principal bodles of virgin tinber remain. This process may be expected to continue in such reglons for a considerable pcriod, first, because in many instances the small plants are less efficient in manufacturing and marketiug lumber and are the first to be eliminated during periods of depression; secondly, because by and large they will be the first mills to exhaust their timber holdings; and, thirdly, because the large interests will find it to their advantage as time goes on to acquire the smaller tracts of stumpage available to their plants. Flnancial strength, strateglc location, ownershlp of the most accessible timber, farreaching affiliatlons of one form or another, including in some Instances affillations with transcontinental railroads-all of these factors wlll tend to give the large Inlerests in the Northwest a greater and greater degree of control of the situation. This control will increase for a considerable period in about the same ratlo as forest depletion goes on, and to a corresponding degree will lnvolve the dangers to the publle interest arising from a natural monopoly.

One of the most important aspects of this control, as already pointed out in the case of the virgin plne timber remaining in the Southern States, is that it will extend particularly to the timber of high quality still left in the steadily reduced areas of old growth. An increasing concentration of high-quallty timber, particularly in the softwood forests of the South and West, may be expected.

On the other hand, a point is reached in every lumber-producing region, after the bulk of its vlrgin timber has been exhausted, when the large plant and organization are no longer the most efficient economically and when the large sawmill, carried by its square miles of virgin stumpage, is replaced by a smaller and more portable operating unit. The small mills follow large ones, picking up odds and ends of virgin timber, cleaning up the less accessible, and ultimately operating on second-growth stands, which produce ordinary grades of building lumber and other products of relatively low quality. This process now appears to be taking place in the southern pine States. During the next 10 years the closing down of large sawmills in that region will be rapid. At the same time the number of small mills is rapidly increasing. These small mills, often operating but a few years at one point, are much less adapted to centralized control and represent a tendency to break up concentration. This tendency may be offset to a degree by the common marketing of the products of a number of small mills through a wholesaler or some form of selling agency and through financial affiliations which may grow out of this marketing relationshlp.

In other words, the lumber industry is distinctive in that the concentration or possible concentration of its raw material is necessalily limlted in time. Under present nretiods of operation the physical conditions restrict the life, even of many large plants, to 20 or 25 years. This broad rule has been true of the dominance of the lumber markets of the United States by the iarge softwood regions, each of which has held control of the nurkets for a comparatively short time. The ultimate tendency is for the industry to break up into small units under which the possibility of concentration is greatly reduced.

The most significant factor in the present situation is that with the exllaustion of virgln timber in most of the eastern States and its lmpending exhaustion in the southern pine r.cginn, although certain large milis will be cutting virgin yellow pine for 30 years to come, the danger of concentration of highgrade timber is proportionately greater than ever before. 'The greatest protection which the people of the United Stales have agaillst such concentration lies in national and other public folests, where such timber can be grown or held in reserve and which are so administered as to aid in malulaining competitive conditions in the lumber business. One of the most effective stens that can be taken to limit the effects of concentration is not only to extend the Nationai Forests by purchase but to incorporate in them ali timberlands which the Federal Government stlll owns or controls and not to permit a single additional acre to pass into private ownership.

As to our requirements for lumber of general utillty, the danger of harmful concentration is more remote. It would be dispelled by vigorous action to stop forest devastation and re- 
stock denuded lands, leading to permanent forest Industries widely distributed over the country, and tending toward small rather than large operating units.

No information has been obtained to justify a conclusion that the tendencies toward a closer knit organization of the Iuniber industry and varlous forms of concentration have led, up to the present time, to actual monopolistic conditions of general scope. It has been impossible in the limited time available for this investlgation to make a study of that phase of the situation. The particular facts which it is believed are clear are that the lumber industry in the regions where the principal supplies of timber remain is growing away from the loose, unorganized, and highly competitive conditions which prevailed in 1914 ; that while during the past 10 years tihere has been no material cliange in the concentration of ownership of standing timber, the eflects of concentration will become more apparent as tinie goes on, particularly in respect to products of high quality; that the financial weaknesses whlch hitherto have tended to keep the lumber manufacturing industry in a highly competitive condition are to solne extent disappearing; and that the lumber industry in the regions of large forest resources is in a process of partial reorganization into larger units of production and marketing. In other words, some of the factors tending to nake this industry highly competitive are changing into conditions more favorable to closer control. The necessity for the steady liquidation of timber investments and the stin enormous number of operating units are inherent factors unfavorable to close controi. 


\section{FOREST DEPLETION THE FUNDAMENTAL PROBLEM.}

\section{CUMULATIVE EFFECTS OF 'TIMBER DEPLETION.}

From the facts presented in this necessarily incomplete report it is evident that the fundamental weakness in the supply and cost of wood products in the United States is the cumulative depletion of our forests. The extent and broad effects of the steady wiping out of the original forest resources of the country are readily grasped. Three-fifths of our primeval forests are gone. The timber remaining is being consumed four times faster than it is being replaced. With the exhaustion of several of our principal forest regions as large producers of wood products, occurring successively in the Northeastem States, the Alleghenies, the Lake States, and the Atlantic seaboard, and the similar exhaustion of the Gulf State pineries now imminent, the cost of transporting forest products to the avernge consumer in steadily lising. Not only does the widening distance between the average sawmill and the average lumber user, between the average tract of pulpwood and the average newspaper, impose an increasing charge for freight; by eliminating former sources of supply and competition it accentuates the evils of abnormal price and transport conditlons such as the country is now experiencing.

In other words, the effects of forest depletion are felt not only, indeed not chiefly, in the diminution of the total quantity of timber remaining. Its injury is felt particularly through the process of regional exhaustion through a location of the timber still remaining so restricted as greatiy to reduce its avallability to the average user of wood. It involves all the elements of higher freight costs, more restricted competltion, dependence upon the efficiency of transportation, dependence upon climatic or labor conditions in restricted regions, and innumerable difficultles in getting needed materials of the right kind and at the right time. If all the timber in the United States were cut and our needs supplied by imports from South America and Slberia, the situation would differ from that which we are now rapidly approaching only in degree. The effect of regional timber exhaustion may be compared with what would happen if the orchards and truck farms in the Lastern and Central States disuppeared and the housewife had to obtain the daily necessitles of her table trom Florida and Califorila.

One of the lirst affects of the depletion of our virgin forests is the seareily of timber products of hIgh quality. This has atready renched a serious stage in the Unlted States, particularty in respect to the high-grade hardwoods which were among the most valuable and distinctive of our original forests. An increasing sbortage of such products as compared with their normal consumption must be expected. Not only will their prices be high but it wlll be increasingly difficult to obtaln many of then in the quantitles required by American manufacturers at any price.

\section{TIMBER DEPLETION AND LUMBER PRICES.}

'Tinber depletion, while not the primary cause, is an in!portant contributing cause of high prices. The large curtailment In lumber production in many regions, due to the cutting out of their forests, has not only made the consumer pay more for his lumber In the form of frelght but has enhanced the effects of congestion in transportation and of climatic and other factors causing temporny curtailment of output in the regions which still support a large lumber industry. It has restricted opportunity for competition and thereby increased the opportunity of the manufacturer or dealer to auction his lumber stocks for higher prlces. This is at least one reason why consumers of lumber In Pittsburgh are in some instances paylng 40 per cent more than consumers of the same material in Portland, Oreg., over and above the freight charge between those points.

If the war had been fought 40 years ago and had brought the sane aftermath in all particulars, it can not be doubted that the presence of a large lumber-producing industry at that time in the Lake States, in the hardwood forests of the Central States, in New York and the northern Alleghenies, and on the Atlantic seaboard would by the very extent of regional competition and the better distribution of transportation have afforded a curb on the upward movement of lumber prices which did not exist in 1919. The continued depletion of our forests will contribute to similar sharp increases in lumber prices in time of transportation or other crises and will also lead to high prlce levels under normal conditions.

Whatever the precise effects of timber depletion upon recent prices, whatever the tendencies in the lumber industry, there can be no question that the real solution is to grow and protect forests.

\section{IDLE FOREST LAND.}

Tle depletion of tinıher in the United States lias not resulted primarily from the use of our forests but from their devastation. The kernel of the problem lies in the enormous areas of forest land which are not producing the timber crops that they should. There are 326 nillion acres of cut-over timberlands In the United States. 'Their condition ranges from complete devastation, through various stages of partial restocking or restocking with trees of inferior quality, to relatively limited areas which are producing timber at or near their full capaclty. On 81 million acres there is practically no forest growth. This is the result of forest fires and of methods of cutting which destroy or prevent new timber growth. There were 27,000 recorded forests fires in 1919 , burning a total of $8 \frac{1}{4}$ inillion acres. During the preceding year, 25,000 fires burned over 10 inillion acres of forest land. An additional large acreage was burned each sear, of which no record could be obtained.

The area of idle or largely idle land is being increased by from 3 to 4 million acres annually as the cutting and burning of forests continue. The enormous area of forest land in the United States not required for any other economic use, estimated at 463 million acres, would provide an ample supply of wood if it was kept productlve. Depletion has resulted, not from using our timber resources but from fallure to use our timber-growing land.

Nor does this situation exist simply in the less developed and thinly settled regions of the country. The State of Massachusetts, as a typical example, contalns denuded forest lands within a stone's throw of her dense population and highly developed industries, which have been estinuated at 1,000,000 acres and whicb are largely idle as far as growlng wood of economic value is concerned.

\section{A NATIONAL FORESTRY POLICY.}

A remedy for this appalling waste must be found in a concertcd effort to stop the devastation of our remalning forests and to put our idle forest lands at work growing timber. It is inconceivable that the United States should forfeit the eco- 
nomic advantage of its enormous timber-growing resources. and that it should go on using up its forests with no provision for growing more until wood products are priced on the basis of imported iuxuries and their use is restricted to the iowest possible scale of civilized existence. The concerted action necessary to put an end to forest devastation must eniist the $\mathrm{Na}$ tional Government, the respective States, and the landowner. It is impractlcable to nationalize ail of the forest iand in the country, or even the major portion of it. On the other hand, the results needed can not he attained if timber production is left to tha initiative of the private owner of land or is sought solely through conpuisory regulation of private lands. Not oniy has the public very large interests at stake which justify an assumption of part of the burden; certain fundamental causes of forest devastation can be removed oniy by pubiic action. Chlef among these are the fire hazard of forest properties, particularly of growing forests, and a property tax system which discourages or may prevent the landowner from engaging in the business of growing timber.

On the other hand, the public can not and should not do it all. A measure of responsibility rests upon the iand owner, and should be recognized in equitable requirements in handiing his land. It is a case of the public and tive private owner alike doing thelr part. Our policy must aim toward timber production on somewhat the same footlng as in France or Scandinavia-as an estabilshed national practlce. Thls calls for a core of public forests, public instruction and exampie, public encouragement in protection and taxation, and a responsibility recognized by forest owners to keep their lands productive. This report would not be complete without indicating the essential steps which should be taken to stop timber depletion. The plan here outlined is built up on the belief that the most. rapid progress will be made by utilizing the recognized police powers of the several States to stop forest fires and bring about better handling of privately owned forest land. The equitable adjustment of tlmberland taxes in such ways as will promote timber production is a responsibility of the individual States. At the same time the national importance of stopping timber depletion calis for the taking of an active part by the Central Government, particularly in aiding the forest actlvities of the States, standardizing technicai practice in fire protection and forest renewal, and iargeiy extending national acquisitions of forest iand.

\section{THE FEDERAL LEGISLATION NEEDED.}

The Feder'al legisiation needed may be summarized briefly as follows:

\section{COOPERATION WITH STATES IN FIRE PROTECTION AND FOREST RENEWAL.}

Legislation is needied, as an extension of section 2 of the act of March 1, 1911 (Weeks law), which will enable the Forest Service to assist the respective States in fire protection, methods of cutting forests, reforestation, and the classification of lands as between timber production and agricuiture. It should carry an initial annual appropriation of not iess than $\$ 1,000,000$, expendable in cooperation with the States, with a proviso that the amount expended in any State during any year shali not exceed the expenditures of the State for the same purposes. The Secretary of Agriculture should be authorized, in making such expenditures, to require reasonable standards in the disposul of siashings, tine protection of timbered and cut-over iands from fire, and the enforcement of equitable requirements in cutting or extracting forest products which he deems necessary to prevent forest devastation in the region concerned, and to witihold cooperation, in whole or in part, from States which do not comply. with these standards in their leglslative or administrative weasures. Federal activities under this law should not be restricted to the watersheds of navigable streams but shoull embrace any class of forest lands in the cooperating States.

This law greatly extending the very limited Federal atd now given to the States in fire protection, will enabie the Forest Service to organize and carry forward a nation-wide drive agalnst the chief cause of devastation-forest fires-and to follow fire protection with such other measures as inay be needed in particular forest regions to stop denudation. It will aiso aid States and private owners in restocking lands already denudei, where tree growth will not come back of itself.

\section{THE EXTENSION AND CONSOLIDATION OF FEDERAL FOREST HOLDINGS.}

Legislation is needed, in part as an extension of section 1 of the act of March 1, 1911 (Weeks law), which will permit the rapid enlargement of the National Forests and the consolidation of existing forest units for more effective administration. This legislation should:

(1) Continue the purchase of forest or cut-over iands, as initiated under the Weeks Act, with annual appropriations of at ieast $\$ 2,000,000$.

(2) Authorize the Secretary of Agriculture to exchange National Forest land, timber, or transferable timber certificates for private timbered or cut-over land within or adjoining existing National Forests.

(3) Withhold from any form of alienation, except under the mineral laws, all lands now in Government ownership or controi but not embraced in National Forests or National Parks, inciuding canceled patents or grants, unreserved public lands, and Indian and military reservations, which are valuabie chiefly for the production of timber or protectlon of watersheds, and ail lands of similar character hereafter revested in or acquired by the United States, and authorize the President, upon recommendation of the Nationai Forest Reservation Commission or otherwise, to incorporate such iands in Nationai Forests.

About a fifth of the forest land in the United States is now publicly owned. One of the most direct and effectlve means of arresting devastatlon and offsetting the dangers arising from concentration of timber in private ownership is the extension of publicly owned forests. It is, under present conditions, the only effective means for overcomlng the depietion of old-growth timber of high quality and for restocking many denuded areas which require planting.

The public should own a half of the timber-growing land in the United States, weli distributed through ali the principal forest regions. Every encouragement should be given to the States and to municipalities to acquire forest land, but the Federal Goverament must take the iead. In ali Federai acquisltions there must be an equitable compensation to communities for the tax returns of which they are deprived.

Appropriations for the purchase of forest lands shouid be used, first, to complete the program laid out for the protection of the watersheds of navigable streams under the Weeks Act, through acquiring about 1 million acres in New England and about 5 million acres in the southern Appaiachians, and, second, to acquire cut-over land, not necessarily upon important watersheds but distributed through all the principai forest regions where areas suitable for Federal management can be obtained. Much desirable timber-growing land in the vicinity of existing National Forests can be acquired by exchange from National Forest timber or timber certificates, and the administration of the National Forests will be improved and simplified through such consolidatlon. As part of this polley it is of the utmost importance that ali timber-growing iand and land valuable chiefly for watershed protection which the Government now owns or controls or in any manuer may acquire shall be witiheld from other disposition, with a view to its incorporation In National Forests. An effective administrative agency for carrying out this policy and for determining the 
best means of liquidating existing equities in such lands, as In the case of Indian reservations, now exists In the Natlonal Forest Reservation Commission, representing three executive departments and both Houses of Congress, which passes upon purchases under the Weeks law.

\section{THE REFORESTATION OF DENUDED FEDERAL LANDS.}

The current appropriations of the Forest Service should provide for the progresslve reforestation of denuded lands in National Forests, to be completed in not more than 20 years, with a yearly sum beglnning at $\$ 500,000$ and Increasing to $\$ 1,000,000$ as soon as the work can be organized on that scale.

The Natlonal Forests contain several million acres of forest land so severely burned that it can not be restocked without planting. To restore this land to timber production is an Lmmediate Federal responsibility. Tree planting is most urgent on denuded watersheds from which water is obtalned for power, irligation, or mnnicipal use. The work already done by the Forest Service has established methods, costs, and the limlts of successfnl reforestation by artificial methods. Thls project can, therefore, be undertaken upon an assured basis of costs and results.

\section{A STUDY OF FOREST TAXATTON AND INSURANCE.}

Legislation carrying a moderate approprlation is needed whlch will anthorize the Secretary of Agriculture to study the effects of the existing tax methods and practices upon forest devastation, to devise model laws on forest taxation, and to cooperate with State agencies in promoting their adoption. The same law should authorize a study of forest insurance looking to the assembling of authentic data on rlsks, practlcable forms of insurance, the distribution of losses, etc.

The annual property tax is not adapted to lands employed in growing 50 or 75 year timber crops, and is an important cause of forest devastation. While land taxes rest with the States, the Federal Government can do much to further wise changes by an authoritative investigation and the formulation of equitable tax laws adapted to tlmber-growing land. Whlle forest insurance must be developed largely by private initiative, investigation will be of material help in promoting this important ald to timber growing by private land owners.

\section{THE SURVEY AND CLASSIFICATION OF FOREST RESOURCES.}

Legislation is needed, with an appropriation of $\$ 3,000,000$, to be available for from two to four years, as the work may require, which will permit the Secretary of Agriculture to survey the forest resources of the United States, determine the present volume, together with the present and possible production of each class of timber in every important forest region, and ascertain the requirements as to quantity and character of timber of each state and of every important wood-using industry. This survey should mark out, by broad lines, timber-growing land from land suited to farm crops to the end that the forestgrowing resources of the United States may be fairly estimated and utilized in consideration of other land uses. Senate bill 3555 , for the survey of pulpwoods, covers part of the comprehensive investigation necessary.

Exact Information upon timber stands or growth and upon the areas of forest as distinct from agricultural land is not to be jad. It is essential for developing a national forest policy designed to supply timber of the kinds and in the quantities and places needed by the country.

\section{CURRENT APPROPRIATIONS FOR FOREST RESEARCII.}

The current approprlatlons of the frorest Service should be sufficient to maintain experlment stations in all the principal forested regions of the United States.

Further research is not necessary to determine the urgency of the actlon proposed. But a continuous study of the technical phases of reforestation in the princlpal timber regions, with theh tremendous dlversity of forests and methods of forestry practice, is essential to carry the national policy forward to the best results. Recent cuts in congressional approprlatlons will necessitate closing the four experiment stations hitherto established in the Western States. Not only should those stations be restored, but provlsion should be made for additlonal experiment stations covering the other important forest regions of the country.

The survey of forest resources should be undertaken at once; but the essential facts as to timber depletion and its causes are so clear that no time should be lost in enacting the legislation recommended, particularly for cooperation with States and the extension of National Forests. The first point of general attack in arresting devastation is to stop forest fires. Hence a law permitting effective Federal and State action in thls matter, as already outlined, is of the greatest urgency.

\section{THE STATE LEGISLATION NEEDED.}

The State legislation necessary to stop forest devastation will necessarily vary in different reglons. Certain essential features of such laws, however, are common to all of the States containing large forest areas. The more important of them may be stated briefly as follows:

\section{FIRE PREVENTION AND REFORESTATION OF PRIVATE LANDS.}

State laws should provide for the organized protection of all forest linds in the state during perlods of fire hazard, the protected areas to include all cutover and unimproved land, as well as bodies of timber. The protective system should include patrols during dry weather, lookout stations, fire breaks and roads where effective, and organized fire-fighting forces. Every forest owner, large or small, should bear hls proportionate share of its cost, about half of whlch may be properly borne by the State itself with the aid of the Federal Government. Police regulations for the control of fire during dry periods, in connection with railroad or industrial operatlons near forest land, land clearing or slash disposal, hunting, etc., and for the control of Incendiarlsm, form an essentlal feature of the piotectlve system.

State laws should establish the responsibility of owners of forest land for complying with such equitable requirements as may be determined upon and promulgated by the proper state agency, dealing with prccautlons against forest fires, the dlsposal of slashings, methods of cutting timber or of extractling particular forest products, such as naval stores or pulpwood, and such other equitable requilements as the anthorized state agency shall determine upon as necessary to prevent devastation. All timbered and cutover land in State or private ownership which is not now required for other uses than tlmber growing should be classed as "forest land" and placed under the control of the State forest organization as far as it deems measures of control necessary to prevent devastation.

The agency in each State charged with the adminlstration of the laws dealing with forest fires and devastation preferably should be a nonpartlsan commission exercising wide latitude under the general anthority of the State in determining equitable regulations applicable to various classes of forest lands. It should have anthority, backed by penalties prescribed in tlie law, to enforce its regulations, subject to appeal by landowners to a judicial review. It should have authority to investigate any questions concerning the forests and forest lndustries of the State and to advise and assist forest owners in carrying out the most effective technical methods on their land. It should have authority and funds for growling planting stock and distributing it to local owners in the State at cost. It should have charge of the acquisition and adminlstration of State forests and of the classlication of receded tax lands to 
TIMBER DEPLETION, PRICES, EXPORTS, AND OWNERSHIP.

71

segregate areas which should be incorporated ln State forests. It should unify ln one body all forest actlvitles of the State. The makeup of this commission should represent the general public, Its forest owners, Its wood-using industries, and other interests or organizations concerned with timber production.

STATE AND MUNICIPAL FORESTS.

Effective progress in restoring the enormous areas of denuder land to timber growth can be made only by largely Increasing public forests. Supplementing the polly of forest acquisition by the Federal Government, every State, including States in the prairie regions, should acquire forest lands or lands adapted to tree growth, and provide systematically for the planting of such areas as will not otherwise restock with timber of valuable species. In the forest regIons State acqulsiion should be concentrated largely upon cut-over lands not needed for other purposes. As a part of this program, provision should be made for the classification of lands owned by the State or acquired through nonpayment of taxes or otherwise, and for the segregation as permanent State forests of areas best suited for growing timber or protecting watersheds.

State laws should encourage the acquisition of forest lands by munlcipalttes, to the end that public-forest ownership may be extended by any agencies capable of undertaking lt. Publicforest ownership not only is the most effective direct attack upon timber depletion; it serves other vital publle Interests, partleularly recreation, the protection of water sources, and the conservation of wild life.

Furthermore, publicly owned and administered forests, widely distributed and setting standards of technical proctie, will be of the greatest educational value and stlunulus to the general adoption by private owners of methods which will keep their lands productive.

TAXATION OF FOREST LANDS.

The adjustment of existing methods of taxation to the growing of timber crops is one of the most essential steps for ar. restlug devastation. Every State containing forest areas should provide for an exhaustlye study of the effects of existing methods and local practices of taxation upon forest devastation, to the end that needed revision of tax laws may be drafted and considered by its legislature. The nation-wlde study of forest taxation proposed for the Federal Government would serve to assist and correlate the consideration of this problem In the respective States.

ADDITIONAL COPIES

OF THIS PUBLICATION MAY BE PROCUrED FROM

THE SUPERINTENDENT OF DOCUMENTS

GOVERNMENT PRINTING OFFICE.

WASHINGTON, D. C.

AT

25 CENTS PER COPY 



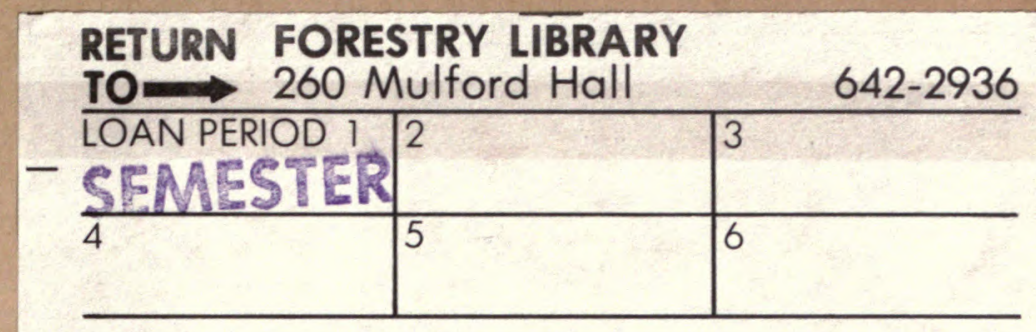

ALL BOOKS MAY BE RECALLED AFTER 7 DAYS

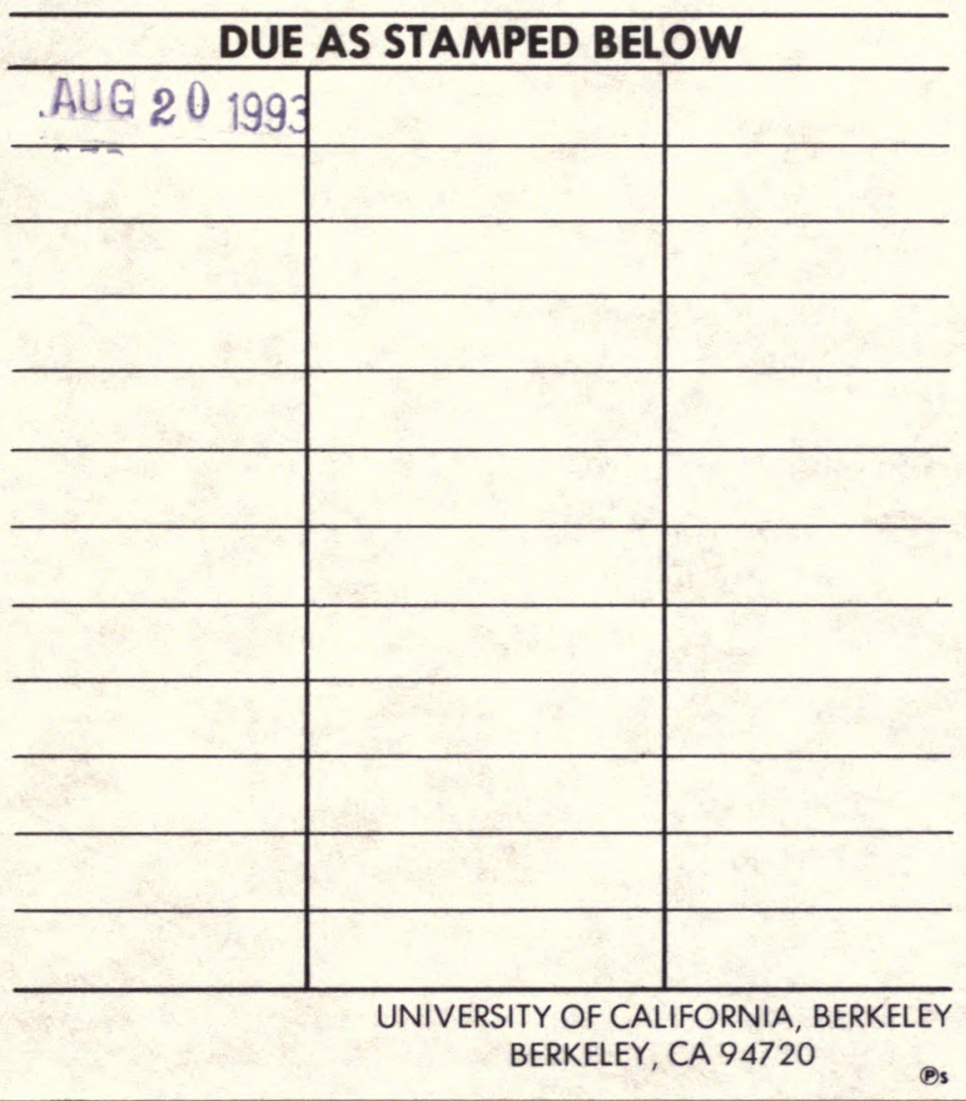




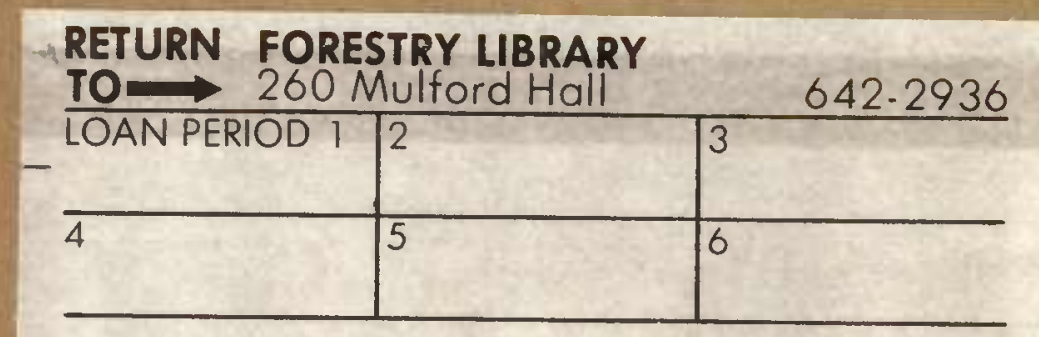

ALL BOOKS MAY BE RECALLED AFTER 7 DAYS

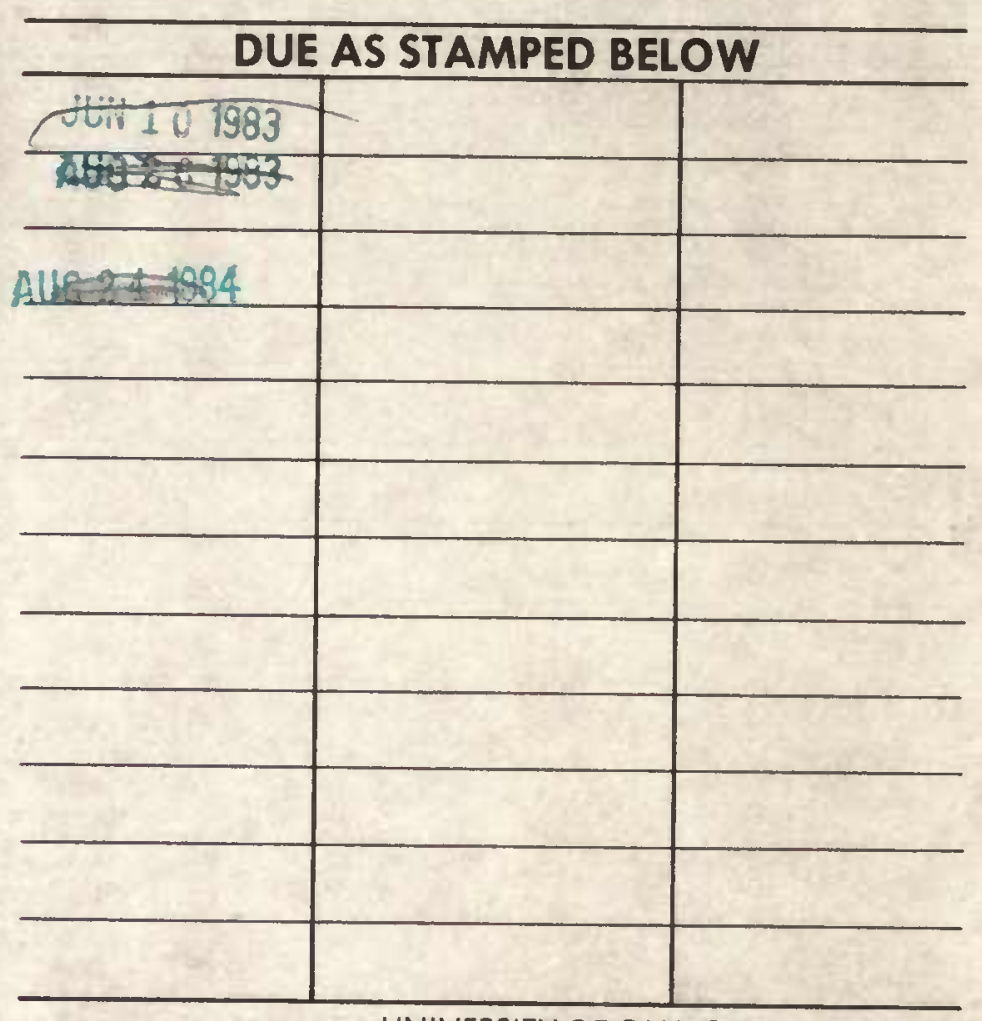

UNIVERSITY OF CALIFORNIA, 8ERKELEY FORM NO. DD $15,9 M 1 / 82$ BERKELEY, CA 94720 


\section{Economics.}

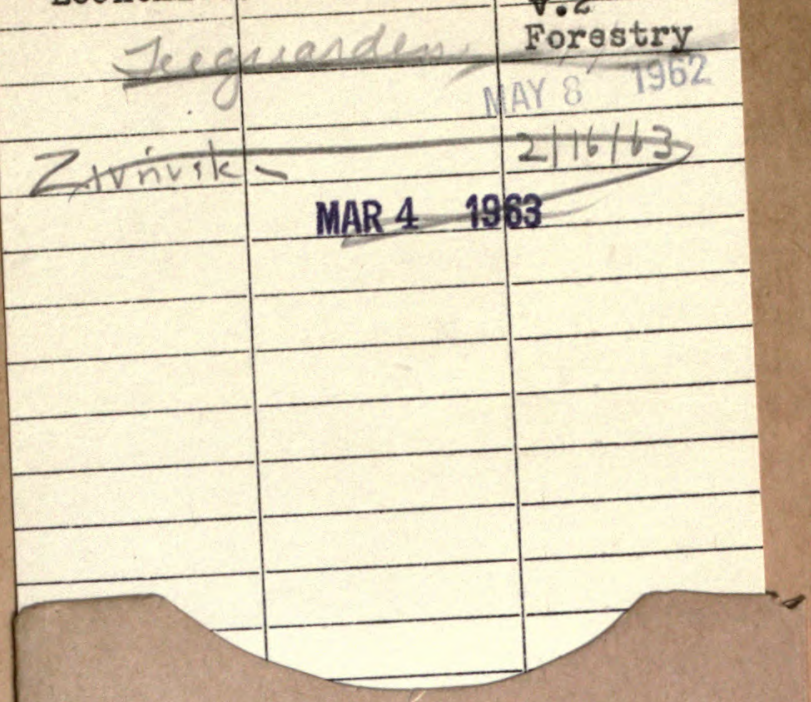

610376

UNIVERSITY OF CALIFORNIA LIBRARY 
